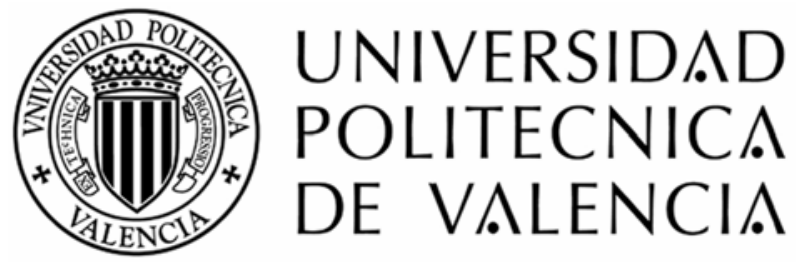

Departamento de Biotecnología

\title{
Análisis transcripcional del desarrollo vegetativo de cítricos y su regulación por giberelinas
}

\author{
Memoria presentada por \\ LAURA HUERTA MARTÍNEZ \\ para optar al grado de \\ DOCTOR INGENIERO AGRÓNOMO \\ Directores \\ José Luis García Martínez \\ Miguel Ángel Pérez Amador
}

Valencia, febrero 2008 

A mis padres,

A Luis 



\section{RESUMEN}

El cultivo de los cítricos representa la mayor producción de frutos en el mundo y España, en particular, ocupa una posición relevante siendo el quinto productor y primer exportador mundial de cítricos para su consumo en fresco. La obtención de variedades de alta calidad comercial y elevada producción, capaces de satisfacer las exigencias del mercado, constituye un objetivo esencial de la citricultura actual. El desarrollo vegetativo determina la forma y el comportamiento general de la planta, de modo que tiene una influencia decisiva en la cantidad y calidad del fruto, así como en las prácticas culturales. Sin embargo, el conocimiento de las señales que regulan el desarrollo vegetativo en cítricos es limitado. En este trabajo se han desarrollado nuevas herramientas de genómica funcional, en particular colecciones de ESTs y micromatrices de DNA, con las que hemos estudiado en detalle diversos aspectos del desarrollo vegetativo en cítricos. Mediante el análisis funcional de una colección de ESTs generada a partir de tejidos vegetativos hemos aislado los genes relacionados con la función principal de estos tejidos, la fotosíntesis. Adicionalmente, a partir de la colección de ESTs del Proyecto de Genómica Funcional de Cítricos (CFGP) hemos identificado genes implicados en el metabolismo de isoprenoides y flavonoides en cítricos. La mayoría de los genes de la biosíntesis de fitohormonas derivadas de isoprenoides, como giberelinas (GAs), brasinosteroides y ácido abscísico no habían sido aislados antes en cítricos. La identificación de los genes de biosíntesis de monoterpenos y sesquiterpenos, responsables del aroma tanto de las hojas como del fruto, ha mostrado que la familia de terpeno sintasas en cítricos es una de las más amplias y diversas en plantas. El análisis de la expresión génica mediante micromatrices de DNA nos ha permitido elaborar mapas de expresión génica en los tejidos reproductivos y en los tejidos vegetativos, incluida la raíz. Mediante estos mapas hemos podido comprender mejor las funciones de cada uno de los tejidos analizados. Finalmente, hemos estudiado la regulación del desarrollo vegetativo mediada por GAs mediante el análisis de la expresión génica de plantas transgénicas del patrón de cítricos citrange Carrizo que sobre-expresan el gen CcGA20ox1 (implicado en la biosíntesis de GAs). Los resultados muestran que la sobre-expresión de dicho gen conlleva una profunda modulación de la expresión génica. En concreto, hemos encontrado, por primera vez en plantas con un contenido elevado de GAs, una inducción global de los genes implicados en la fotosíntesis y en el ciclo de Calvin y una represión general de los genes relacionados con la síntesis de proteínas y con la biogénesis de ribosomas, lo que sugiere que dichos procesos están regulados por GAs. Además, hemos podido determinar que la activación transcripcional de los genes 
relacionados con la fotosíntesis conduce a un aumento de la capacidad de fijación fotosintética de $\mathrm{CO}_{2}$ de estas plantas. La expresión de genes que pertenecen a grupos funcionales no descritos previamente como grupos regulados por GAs (como estrés de origen biótico y abiótico o biosíntesis de la cutícula), así como de genes relacionados con la arquitectura de la pared celular se encuentra asimismo modificada en las plantas que sobre-expresan el gen CcGA20ox1. Las herramientas de genómica funcional generadas en este trabajo con su potencial para aislar genes de interés agronómico, para generar marcadores moleculares y para caracterizar colecciones de germoplasma, entre otros, podrían contribuir al desarrollo de nuevos cultivares de cítricos adaptados a las condiciones ambientales y cuya producción pueda satisfacer las características deseadas por los consumidores. 


\section{RESUM}

El cultiu dels cítrics representa la major producció de fruits en el món i Espanya, en particular, ocupa una posició rellevant sent el cinqué productor i primer exportador mundial de cítrics per al seu consum en fresc. L'obtenció de varietats d'alta qualitat comercial i elevada producció, que s'adapten a les exigències del mercat, constituïx un objectiu essencial de la citricultura actual. El desenvolupament vegetatiu determina la forma i el comportament general de la planta, i té una influència decisiva en la quantitat i qualitat del fruit, així com en les pràctiques culturals. Així i tot, el coneixement dels senyals que regulen el desenvolupament vegetatiu en cítrics és limitat. En aquest treball s'han desenvolupat noves eines de genòmica funcional, en particular col-leccions d'ESTs i micromatrius de ADN, amb les que hem estudiat en detall diferents aspectes del desenvolupament vegetatiu en cítrics. Mitjançant l'anàlisi funcional d'una col-lecció d'ESTs generada a partir de teixits vegetatius hem aïllat els gens relacionats amb la funció principal d'aquests teixits, la fotosíntesi. A més, a partir de la col-lecció d'ESTs del Projecte de Genòmica Funcional de Cítrics (CFGP) hem identificat gens implicats en el metabolisme d'isoprenoids i flavonoids en cítrics. La majoria dels gens de la biosíntesi de fitohormones derivades d'isoprenoids, com giberelines (GAs), brasinosteroids i àcid abscísic no havien sigut aïllats abans en cítrics. La identificació dels gens de biosíntesi de monoterpenos i sesquiterpenos, responsables de l'aroma de fulles i fruits, ha mostrat que la família de terpeno sintasas en cítrics és una de les més àmplies i diverses en plantes. L'anàlisi de l'expressió gènica per mitjà de micromatrius de $\mathrm{ADN}$ ens ha permés elaborar mapes d'expressió gènica en teixits reproductius i vegetatius, inclosa l'arrel. Mitjançant aquests mapes hem pogut comprendre millor les funcions de cadascun dels teixits analitzats. Per últim, hem estudiat la regulació del desenvolupament vegetatiu per GAs per mitjà de l'anàlisi de l'expressió gènica de plantes transgèniques del patró de cítrics citrange Carrizo que sobre-expressen el gen CcGA200x1 (implicat en la biosíntesi de GAs). Els resultats mostren que la sobre-expressió d'aquest gen suposa una profunda modulació de l'expressió gènica. En concret, hem trobat, per primera vegada en plantes amb un contingut elevat de GAs, una inducció global dels gens implicats en la fotosíntesi i en el cicle de Calvin i una repressió general dels gens relacionats amb la síntesi de proteïnes i amb la biogènesi de ribosomes, suggerint que aquests processos estan regulats per GAs. A més, hem pogut determinar que l'activació transcripcional dels gens relacionats amb la fotosíntesi conduïx a un augment de la capacitat de fixació fotosintètica de $\mathrm{CO}_{2}$ d'aquestes plantes. L'expressió de gens que pertanyen a grups funcionals no descrits prèviament com a grups regulats per GAs (com a estrès d'origen 
biòtic i abiòtic o biosíntesi de la cutícula), així com de gens relacionats amb l'arquitectura de la paret cel-lular es troba així mateix modificada en les plantes que sobre-expressen el gen CCGA200x1. Les eines de genòmica funcional generades en aquest treball, amb el seu potencial per a aïllar gens d'interès agronòmic, per a generar marcadors molecul-lars i per a caracteritzar col-leccions de germoplasma, entre altres, podrien contribuir al desenvolupament de nous cultivars de cítrics adaptats a les condicions ambientals i amb una producció capaç de satisfer les característiques desitjades pels consumidors. 


\section{ABSTRACT}

Citrus are the most important fruit tree crop in the world and Spain is the fifth producer and the first world-wide exporter of citrus for fresh consumption. A main objective in citrus research is the improvement of citrus quality and production. Vegetative development is important in determining the shape and the general performance of trees, and has a decisive influence in the amount and quality of fruit production, as well as in culture practices. However, very little is known about the regulation of vegetative development in citrus. In this work, we have developed new genomic tools for large-scale studies of citrus vegetative growth, including the generation of an EST collection and the construction of cDNA microarrays. Genes involved in photosynthesis were identified by functional analysis of an EST collection generated from vegetative tissues. In addition, we have analyzed 85,965 ESTs from the Citrus Functional Genomic Project to characterize the isoprenoid and flavonoid metabolic pathways in citrus. Genes involved in gibberellin (GA), brassinosteroid and abscisic acid biosynthesis were identified for the first time in citrus. Identification of monoterpene and sesquiterpene synthases showed that citrus terpene synthase genes represents one of the largest and diverse terpene synthase family in plants. Expression maps of vegetative and reproductive organs were generated using cDNA microarrays. Major functions of each organ were characterized using these expression maps. The effect of GA on internode transcriptome was investigated in transgenic Carrizo citrange plants (a citrus hybrid widely used as a rootstock) overexpressing endogenous CcGA20ox1 (encoding a GA biosynthetic enzyme), using a citrus cDNA microarray. Substantial modulation of gene expression was found in these plants. Extensive upregulation of genes involved in photosynthesis and carbon utilization, and downregulation of those involved in protein synthesis and ribosome biogenesis was shown for the first time in plants with higher GA content, suggesting that these processes are regulated by GA. Importantly, increase of net photosynthesis in attached leaves was also demonstrated. In addition, the expression of other genes belonging to functional groups not reported previously to be regulated by GA (diverse abiotic and biotic stresses, and cuticle biosynthesis), as well as genes involved in cell wall architecture were also differentially expressed. Functional genomic tools developed in this work, with their potential to: i) isolate genes of agronomical relevance, ii) generate molecular markers and iii) characterize germplasm collections, will be of great help in the development of varieties that are well adapted to environmental conditions and produce fruits exhibiting those characteristics desired by most consumers. 



\section{INTRODUCCIÓN}

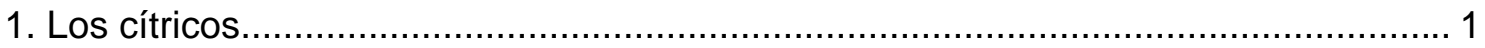

1.1. El género Citrus y su importancia económica............................................ 1

1.2. Desarrollo vegetativo de los cítricos .................................................... 3

1.2.1. Aspectos generales................................................................... 3

1.2.2. Control del desarrollo vegetativo............................................... 4

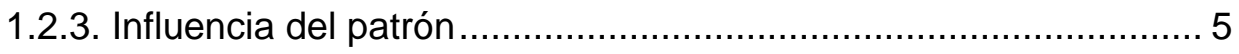

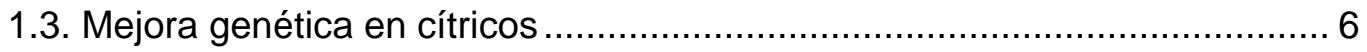

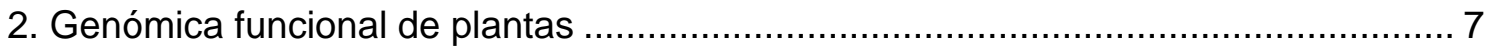

2.1. Colecciones de ESTs: herramientas para la identificación de genes, el análisis de la expresión génica y el desarrollo de marcadores moleculares ...... 8 2.2. Micromatrices de DNA: la revolución del análisis de la expresión génica 11

2.3. El Proyecto de Genómica Funcional de Cítricos (CFGP) ........................ 13

3. Aproximación genómico-funcional a diversos aspectos del desarrollo vegetativo en cítricos 15

3.1. Biosíntesis de isoprenoides y flavonoides ........................................... 15

3.1.1. Biosíntesis de isoprenoides ................................................. 15

3.1.2. Biosíntesis de flavonoides................................................... 18

3.2. Mapas de expresión génica en plantas ............................................... 20

3.3. Control del desarrollo vegetativo: giberelinas ......................................... 21

3.3.1. Metabolismo de giberelinas (GAs) ..................................... 21

3.3.2. Modificación de la arquitectura de las plantas mediante cambios en los niveles de GA 20-oxidasas ............................................... 23

3.3.3. Identificación de genes de respuesta temprana a GAs ............. 25

OBJETIVOS 29

\section{MATERIALES Y MÉTODOS}

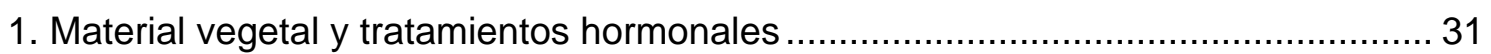

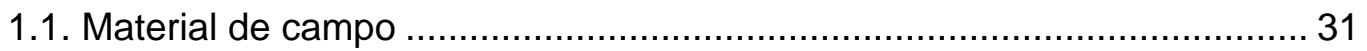

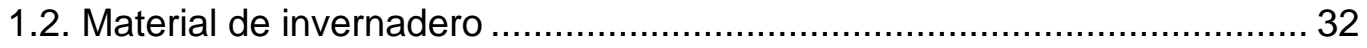

2. Extracción de RNA y RNA poli(A $\left.{ }^{+}\right)$de plantas................................................ 32

2.1. Protocolo general de extracción de RNA total ....................................... 33

2.1.1. Purificación adicional del RNA para los experimentos con micromatrices.............................................................................. 33 
2.1.2. Purificación adicional del RNA para los experimentos de

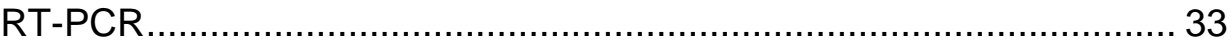

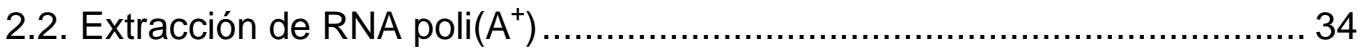

3. Construcción y manipulación de una genoteca de cDNA ….................................. 34

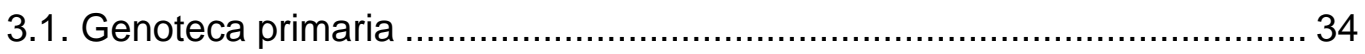

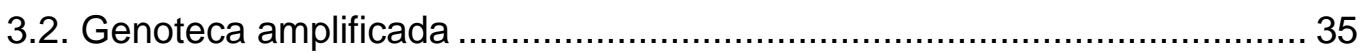

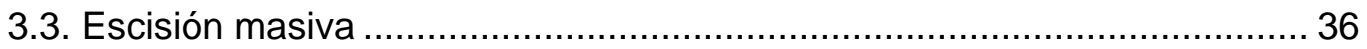

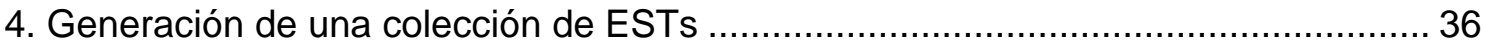

4.1. Obtención de DNA plasmídico y secuenciación ....................................... 36

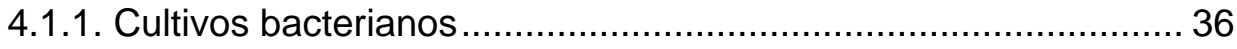

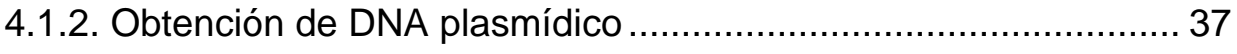

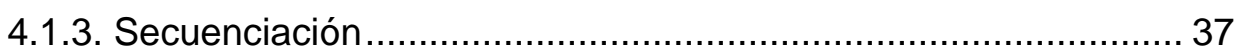

4.2. Pre-procesado y ensamblaje de ESTs .............................................. 38

4.3. Anotación funcional de los unigenes ..................................................... 39

4.3.1. Métodología para la anotación básica de los unigenes: base de

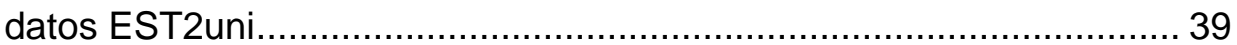

4.3.2. Métodos para la anotación adicional de los unigenes ............... 39

4.4. Análisis de expresión génica según la frecuencia de ESTs .................... 41

5. Construcción de la micromatriz de cDNA de cítricos CIT1 .................................. 42

6. Experimentos de micromatrices de cDNA ............................................................ 43

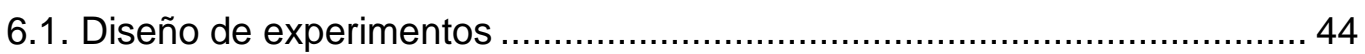

6.2. Preparación de muestras de cDNA marcadas......................................... 46

6.2.1. Marcaje mediante el método indirecto .................................... 46

6.2.2. Caracterización de las propiedades del cDNA marcado............. 47

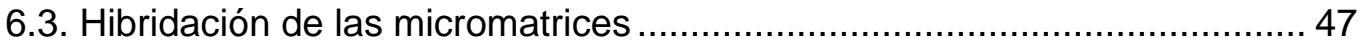

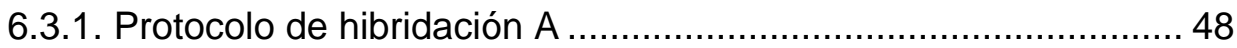

6.3.2. Protocolo de hibridación B ................................................... 49

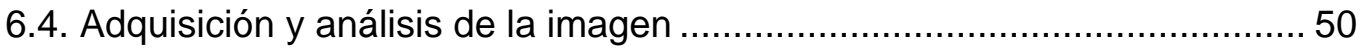

6.5. Pre-procesado y normalización de los datos ...................................... 51

6.6. Evaluación de la calidad de los datos obtenidos con micromatrices ......... 53

6.6.1. Parámetros de calidad de GenePix .......................................... 53

6.6.2. Validación técnica de la micromatriz CIT1 ................................ 54

6.7. Identificación de los genes expresados diferencialmente......................... 55

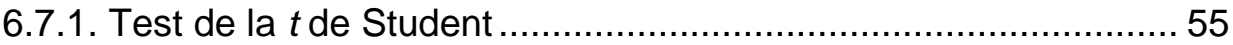

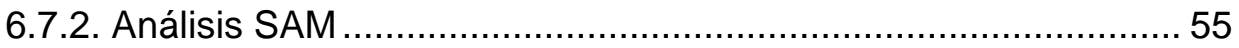

6.7.3. El problema de las pruebas múltiples ...................................... 56

6.8. Análisis de agrupamiento y análisis funcional de los datos ..................... 56 


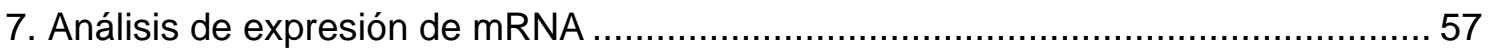

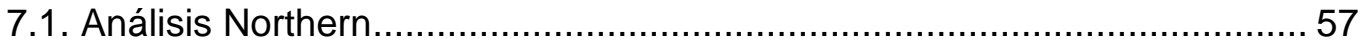

7.1.1. Electroforesis en gel de agarosa desnaturalizante ................... 57

7.1.2. Transferencia de RNA a membranas de nylon .......................... 57

7.1.3. Obtención de las sondas de DNA ............................................. 58

7.1.4. Hibridación con sondas radiactivas........................................... 58

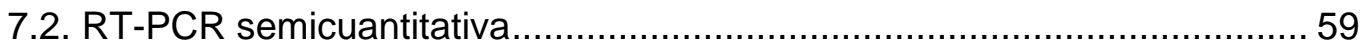

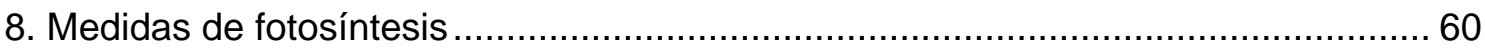

\section{RESULTADOS Y DISCUSIÓN I: Análisis funcional de ESTs de cítricos}

1. Genes implicados en el desarrollo vegetativo en cítricos ....................................61

1.1. Obtención de una genoteca de tejidos vegetativos ................................. 61

1.2. Colección de ESTs: secuenciación y agrupamiento................................. 62

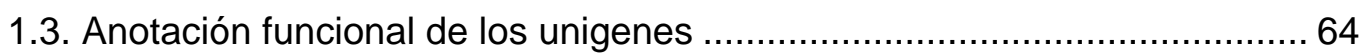

1.4. Ontologías génicas enriquecidas en Veg1 .............................................. 65

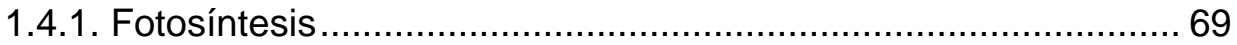

1.4.2. Fotosíntesis: proteínas de la antena ........................................ 70

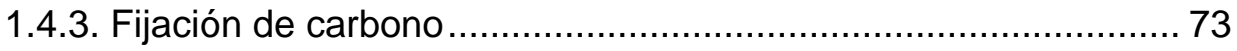

2. Genes implicados en el metabolismo de isoprenoides y flavonoides en cítricos ..... 74

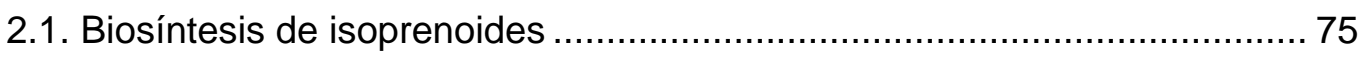

2.1.1. Biosíntesis de isopentenil difosfato y dimetilalil difosfato ............ 75

2.1.2. Prenildifosfatos: precursores de los distintos tipos de terpenoides

2.1.3. Biosíntesis de monoterpenos y sesquiterpenos: aceites esenciales 83

2.1.4. Biosíntesis de triterpenos: brasinosteroides y limonoides .......... 88

2.1.5. Biosíntesis de diterpenos: giberelinas.................................... 92

2.2. Biosíntesis de flavonoides 94

\section{RESULTADOS Y DISCUSIÓN II: Mapas transcripcionales en cítricos}

1. Caracterización de la micromatriz de cDNA de cítricos, CIT1, generada en el

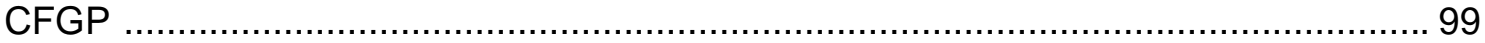

1.1. Caracterización técnica de la micromatriz CIT1 …................................ 99

1.1.1. Rango dinámico y niveles de sensibilidad ............................. 100

1.1.2. Reproducibilidad intra-array .............................................. 101

1.1.3. Reproducibilidad inter-array .............................................. 103 
1.2. Validación de la micromatriz CIT1 como herramienta para identificar cambios en la expresión génica en cítricos 104

2. Caracterización de diferentes tejidos de cítricos mediante el análisis global de la expresión génica. 108

2.1. Identificación de los genes comúnmente expresados en diversos tejidos de cítricos 108

2.2. Relación entre los tejidos estudiados según los perfiles de expresión génica

2.3. Identificación de los genes preferentemente expresados en la raíz

2.4. Identificación de los genes preferentemente expresados en los tejidos reproductivos

2.5. Identificación de los genes preferentemente expresados en los tejidos vegetativos

\section{RESULTADOS Y DISCUSIÓN III: Regulación del transcriptoma de cítricos por giberelinas}

1. Cambios en la expresión génica de entrenudos de plantas transgénicas de cítricos que sobre-expresan una GA 20-oxidasa

1.1. La sobre-expresión en sentido y en antisentido del gen CcGA200x1 modifica los niveles de transcritos endógenos de CCGA200x1

1.2. La sobre-expresión en sentido del gen CCGA20ox1 causa un remodelado substancial del transcriptoma

1.3. La sobre-expresión en sentido del gen CcGA20ox implica la sobrerepresentación de diversas ontologías génicas

1.3.1. Fotosíntesis y Utilización de Carbono. 129

1.3.2. Biosíntesis de Proteínas

1.4. La activación transcripcional de los genes relacionados con la fotosíntesis conduce a un aumento en la capacidad fotosintética de las plantas CcGA200x

1.5. La sobre-expresión en sentido del gen CcGA20ox1 provoca cambios en los niveles de expresión de genes específicos.

1.5.1. Metabolismo de GAs

1.5.2. Biosíntesis y modificación de la pared celular 134

1.5.3. Biosíntesis de lignina 136

1.5.4. Estrés de origen abiótico. 137

1.5.5. Estrés de origen biótico. 140 
1.5.6. Factores de transcripción. 140

2. Cambios en la expresión génica de entrenudos de explantes tratados con $\mathrm{GA}_{3} \ldots 142$ 2.1. La aplicación de $\mathrm{GA}_{3}$ a tiempos cortos altera el transcriptoma de los entrenudos de explantes de cítricos 142

CONCLUSIONES 147

BIBLIOGRAFÍA 149

\section{ANEJOS}

Anejo I 173

Anejo II 193

Anejo III 201 



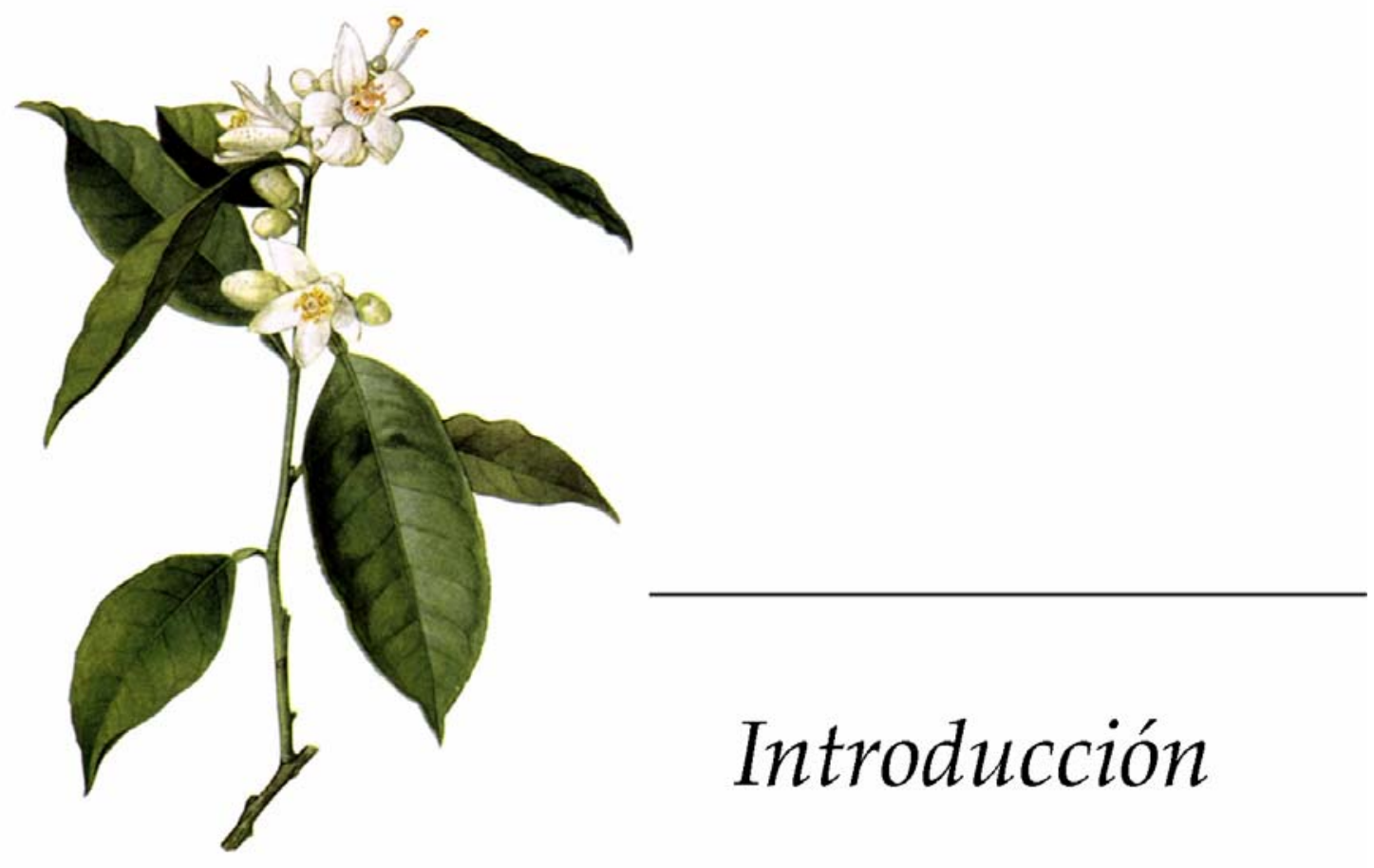





\section{LOS CÍTRICOS}

\subsection{El género Citrus y su importancia económica}

Las principales especies comerciales de cítricos son árboles de hoja perenne, con orígenes tropicales y subtropicales y que pertenecen a la familia Rutaceae, subfamilia Aurantioideae. Las plantas de esta subfamilia se caracterizan por un fruto en forma de baya en hesperidio procedente de un ovario multicarpelar, que contiene vesículas de zumo y una corteza coriácea con alta densidad de glándulas esenciales. Una segunda característica de muchas de las especies de esta subfamilia es la presencia de semillas poliembriónicas que contienen tanto embriones cigóticos como nucelares, producidos sin fecundación previa a partir de la nucela, mediante el fenómeno de la apomixis (Davies y Albrigo, 1994). La ordenación de la subfamilia Aurantioideae resulta compleja debido a que los cítricos hibridan con bastante facilidad, incluso entre diferentes géneros, tienen una elevada tasa de mutaciones espontáneas y, como consecuencia de la apomixis, las variaciones genéticas tienden a perpetuarse (Davies y Albrigo, 1994). Los tres géneros de cítricos cultivados en la actualidad son: 1) Fortunella (kumquat), 2) Poncirus, formado por especies de hoja trifoliada caduca, de gran resistencia al frío y utilizados como portainjertos, y 3) Citrus, que incluye las especies más importantes desde el punto de vista agronómico como las naranjas dulces (Citrus sinensis [L.] Osb.), mandarinas (Citrus reticulata Blanco y Citrus unshiu Marc.), pomelos (Citrus paradisi Macf.), limones (Citrus limon Burm. f.) y limas (Citrus aurantifolia L.). La sistemática del género Citrus también es controvertida ya que según Swingle y Reece (1967) este género está formado por 16 especies mientras que según Tanaka (1977) comprende 162 especies. Recientemente, diversos trabajos tratan de evaluar la variabilidad genética del género Citrus mediante marcadores moleculares (Moore et al, 2001; Barkley et al 2006; Ancillo et al, 2007). La gran mayoría de las especies de los géneros Citrus, Fortunella y Poncirus son diploides, con un número básico de cromosomas $x=9(2 x=2 n=18)$, excepto Fortunella hindsii que es tetraploide $(4 x=2 n=36)$. El tamaño estimado del genoma de cítricos es de $382 \mathrm{Mb}$ (Arumuganathan et al, 1991), inferior al de arroz (419 Mb) (Goff et al, 2002; Yu et al, 2002) y unas tres veces superior al tamaño del genoma de Arabidopsis (125 Mb) (Arabidopsis Genome Initiative, 2000).

El área general de origen de los cítricos se localiza en el sureste de Asia, en una zona que abarca desde Arabia Oriental hasta Filipinas, y desde el Himalaya hasta Indonesia. Dentro de esta gran región, el noreste de la India, el norte de Birmania y la provincia de Yunnan (en el centro-sur de China), se consideran los tres centros de 
origen más importantes (Gmitter y Hu, 1990). Actualmente el cultivo de los cítricos se extiende por la mayor parte de las regiones tropicales y subtropicales comprendidas entre las latitudes $44^{\circ} \mathrm{N}$ y $41^{\circ} \mathrm{S}$ (Agustí, 2000). Los cítricos se cultivan en más de un centenar de países, en una superficie total de 6.7 millones de hectáreas y alcanzan una producción de 108 millones de toneladas, cifra muy superior a la de otras frutas como los plátanos (70 millones de toneladas) o las uvas (69 millones) (Tabla Suplementaria I) (FAO, 2006; http://www.fao.org). España, con una producción de poco más de 6 millones de toneladas, ocupa el quinto lugar en la producción mundial de cítricos, precedido de Brasil (20 millones de toneladas), China (supera los 17 millones de toneladas), EEUU (11 millones de toneladas) y México (6.5 millones de toneladas). La producción de naranjas es la mayoritaria a nivel mundial (60\%), seguida de la de mandarinas (24\%), limones (12\%) y pomelo (4\%) (Tabla Suplementaria I) (FAO, 2006). Las exportaciones mundiales de cítricos superan los 12 millones de toneladas (FAO, 2005) y España es el país con el mayor volumen de exportación de cítricos para su consumo en fresco del mundo con más de 3 millones de toneladas, seguido por Suráfrica y EEUU con 2 y 1 millón de toneladas, respectivamente (Tabla Suplementaria I) (FAO, 2005). Esto significa que España puede canalizar en torno al $25 \%$ del comercio mundial de cítricos. España es el primer exportador mundial de mandarinas y limones (Tabla Suplementaria I) y su mercado más importante es la UE, principalmente Alemania y Francia, países a los que destina el 50\% de la exportación (Tabla Suplementaria I) (FAO, 2005). La producción de cítricos en España se localiza en cuatro comunidades autónomas: la Comunidad Valenciana, que constituye la zona de producción más importante (62\% de la producción nacional), Andalucía (22\%), Región de Murcia (13.5\%) y Cataluña (2.5\%) (MAPA, 2006; http://www.mapa.es). Los cítricos de mayor producción en España son las naranjas (53\%), seguidas de las mandarinas (33\%) y los limones (14\%) y la Comunidad Valenciana lidera la producción de naranjas y mandarinas (MAPA, 2006). En el grupo de las mandarinas, destaca la producción de clementinas (82\%), especialmente de la variedad clementino de Nules (Citrus clementina Hort. ex Tan.).

La importancia de la citricultura en el mundo, y en particular en España, está fuera de toda duda. Sin embargo, no se halla exenta de serios problemas como techos en el consumo y producciones crecientes que conducen a una caída de precios. El avance de la citricultura implica una mejora de la rentabilidad de las explotaciones que pasa por la reducción de los costes de cultivo, la reducción de la estacionalidad de la oferta o la mejora de la calidad del fruto (Agustí, 2000). La obtención de variedades de alta calidad comercial y elevada producción, capaces de satisfacer las exigencias del mercado constituye un objetivo esencial ligado a la mejora del material vegetal. 


\subsection{Desarrollo vegetativo de los cítricos}

\subsubsection{Aspectos generales}

En condiciones subtropicales los cítricos presentan un crecimiento anual discontinuo con periodos de crecimiento efectivo que se alternan con periodos de inactividad vegetativa. Estos periodos de crecimiento e inactividad vegetativa están ligados a los cambios climáticos anuales como las condiciones de humedad, temperatura, fotoperiodo e irradiación. En las condiciones de clima mediterráneo los cítricos entran en latencia, aunque sin perder sus hojas, hacia mediados de otoño, concluyendo dicho periodo de reposo invernal a finales de invierno o principios de primavera (Davies y Albrigo, 1994). Durante el periodo de actividad vegetativa, el desarrollo de la parte aérea tampoco se produce de forma continua sino en ciclos definidos denominados brotaciones. En nuestras condiciones climáticas se producen tres brotaciones: una en primavera, otra en verano y otra en otoño. La brotación de primavera tiene lugar en marzo o abril tras el periodo de latencia y es muy importante puesto que coincide con el principal periodo de floración, por lo que determina la cosecha. Los brotes que surgen en primavera se clasifican de acuerdo con el número de hojas y flores que los forman de modo que pueden distinguirse: 1) ramos de flor 0 brotes multiflorales sin hojas, 2) brotes mixtos o brotes multiflorales con varias hojas, 2) flores solitarias o brotes uniflorales sin hojas, 4) brotes campaneros o brotes uniflorales con hojas y 5) brotes vegetativos o brotes que únicamente están formados por hojas (Agustí, 2000). La segunda brotación, a principios de verano (junio), y la tercera (septiembre), que precede a un nuevo periodo de inactividad vegetativa, son exclusivamente vegetativas en condiciones normales y determinan la envergadura del árbol. Estas dos brotaciones difieren de la de primavera no sólo por la ausencia de flores, sino porque las hojas son de mayor tamaño y los brotes, aunque en menor número, son de mayor longitud y vigor. El crecimiento vegetativo depende, por tanto, de la segunda y tercera brotación (Davies y Albrigo, 1994). Los factores que determinan la brotación no son muy bien conocidos. No parece existir requerimientos de frío y las yemas brotan en cualquier época del año cuando la temperatura del suelo supera los $12^{\circ} \mathrm{C}$, con independencia de la del aire (Agustí, 2000).

El desarrollo de los árboles de cítricos pasa por dos etapas: el periodo juvenil y el adulto. El periodo juvenil es relativamente prolongado (puede oscilar entre 5 y 10 años) y su duración varía para cada especie y según factores ambientales como la temperatura y la humedad. El periodo juvenil se define como aquél en el que la planta presenta una capacidad de crecimiento vegetativo elevada, lo que se traduce en un 
mayor vigor, es incapaz de inducir el proceso de floración, por lo que se produce una entrada en producción tardía, y desarrolla espinas, estructuras morfológicas características de este periodo (Agustí, 2000). En la fase juvenil el hábito de crecimiento del árbol es muy erecto, sin apenas ramificaciones. Durante el crecimiento del árbol, el meristemo apical se desprende y surgen yemas laterales a lo largo del eje central. Los nuevos tallos surgen de yemas vegetativas laterales y, a su vez, el meristemo apical de estos tallos se desprenderá y emergerán otras yemas laterales. Este patrón de crecimiento en zig-zag, llamado crecimiento simpodial, es característico de la mayoría de las especies de cítricos (Davies y Albrigo, 1994). La mayor tasa de crecimiento vegetativo durante el periodo juvenil se ha relacionado con una ausencia de competencia entre puntos de desarrollo de modo que cuando estos puntos son numerosos la competencia por nutrientes aumenta, aparece una gradual pérdida de la dominancia apical y una orientación geotrópica de los tallos que marca el final del periodo juvenil (Agustí, 2000). Dado que la elongación de los tallos vegetativos termina con la abscisión de la yema terminal, los árboles tienen un hábito de crecimiento determinado (Davies y Albrigo, 1994). Las hojas de los cítricos comienzan su expansión antes de que finalice la elongación del tallo. Las hojas en desarrollo son generalmente importadoras de carbono, hasta su total expansión. La asimilación neta de $\mathrm{CO}_{2}$ aumenta durante el desarrollo de la hoja, alcanza un máximo a los 3-4 meses de edad y comienza a descender a partir de los 6 meses. Pese a ello, las hojas continúan activas hasta que caen, lo que puede suceder tras dos años. Además de su papel de asimilación de carbono, las hojas funcionan como órganos de reserva de nutrientes. El principal carbohidrato de reserva es el almidón. Mientras que las hojas de las plantas anuales muestran un claro ciclo diurno en el que todo el almidón se elimina durante la noche, las hojas de los cítricos conservan la mayor parte del almidón de modo que sólo se observan pequeñas fluctuaciones diurnas (Spiegel-Roy y Goldschmidt, 1996).

\subsubsection{Control del desarrollo vegetativo}

Las condiciones ambientales, de suma importancia en el desarrollo vegetativo, operan a través de su influencia sobre el balance hormonal y la movilización de reservas. La temperatura es, probablemente, la variable climática de mayor influencia en el desarrollo de los cítricos y determina los periodos de inactividad vegetativa. La temperatura del suelo influye sobre el número de nuevos brotes y la temperatura del aire durante el día influye sobre la longitud de los brotes (Agustí, 2000). El desarrollo 
óptimo de los brotes se produce entre los 22 y $34^{\circ} \mathrm{C}$ y no se relaciona con la alternancia de temperaturas entre el día y la noche (Ben-Cheikh, 1997a).

La intensidad de la luz también afecta al crecimiento y desarrollo vegetativo. La luz se ha relacionado con el desarrollo de nuevos brotes de modo que en las zonas internas del árbol, con una intensidad luminosa limitada, la brotación es menor. La intensidad de la luz tiene un efecto directo sobre la asimilación neta de $\mathrm{CO}_{2}$ por las hojas y un efecto indirecto sobre la temperatura de las mismas. El crecimiento vegetativo de los cítricos está estrechamente relacionado con la asimilación neta de $\mathrm{CO}_{2}$, suponiendo que otros factores como la temperatura, nutrición y agua no sean limitantes. La asimilación neta de $\mathrm{CO}_{2}$ aumenta de modo lineal con el aumento de la radiación fotosintética activa (PAR) hasta alcanzar un máximo de eficiencia fotosintética entre 700 y $1000 \mu \mathrm{mol} \cdot \mathrm{m}^{-2} \cdot \mathrm{s}^{-1}$ y las mesetas por encima de este nivel se conocen como nivel de saturación de luz (Syvertsen, 1984). La asimilación neta de $\mathrm{CO}_{2}$ será potencialmente mayor cuanto más tiempo permanezca el árbol en condiciones de saturación de luz. Por lo tanto, el crecimiento vegetativo de los cítricos suele ser mayor cuando la duración del día es de moderada a larga (>12 h), cuando se logran las mayores unidades de calor y cuando el agua no es un factor limitante. Sin embargo, intensidades de luz extremadamente altas pueden provocar una disminución de la asimilación neta de $\mathrm{CO}_{2}$ debido a que conllevan un aumento de la temperatura de la hoja. Las temperaturas óptimas de asimilación neta de $\mathrm{CO}_{2}$ en los cítricos oscilan entre 25 y $30^{\circ} \mathrm{C}$. Las temperaturas superiores a $35^{\circ} \mathrm{C}$ reducen la actividad fotosintética porque limitan la actividad de la ribulosa 1,5-bisfosfato carboxilasa/ oxidasa (RuBisCO) (Davies y Albrigo, 1994).

La disponibilidad, movilización y suministro de nutrientes y agua al brote en desarrollo son esenciales para la síntesis de los constituyentes celulares y, por tanto, para su crecimiento. Así pues, la elongación y la acumulación de materia seca en los brotes, en condiciones no limitantes de disponibilidad de agua y nutrientes, se ven favorecidas por días largos y temperaturas medias moderadamente altas, tanto durante el día como por la noche (Davies y Albrigo, 1994). La correlación entre la síntesis y el transporte de hormonas es la responsable del crecimiento periódico de brotes y ramas. En particular, la aplicación de giberelinas al inicio de la brotación estimula el crecimiento de los brotes iniciados y de sus hojas (Agustí, 2000).

\subsubsection{Influencia del patrón}

Los árboles de cítricos cultivados en la actualidad están formados por dos partes, el patrón y la variedad, la segunda injertada sobre el primero, de modo que 
combinen entre sí las mejores características posibles. La elección del patrón es fundamental porque: 1) aporta a la planta el sistema radicular, que ancla la planta al suelo, absorbe agua y nutrientes, acumula carbohidratos y sintetiza algunas hormonas, 2) permite la adaptación de la variedad a las condiciones particulares del suelo confiriendo tolerancia a factores desfavorables como caliza, sequía y salinidad y 3) confiere tolerancia a ciertas enfermedades. El patrón influye en muchas de las características de una variedad como el vigor y el tamaño del árbol, el desarrollo y la profundidad de las raíces, la cosecha y el tamaño y la calidad del fruto (Agustí, 2000).

Uno de los patrones más extendidos en la citricultura española actual es citrange Carrizo de modo que un $90 \%$ de las nuevas plantaciones están injertadas sobre este patrón. El patrón citrange Carrizo (Citrus sinensis L. Osbeck x Poncirus trifoliata L. Raf.) es un híbrido obtenido por Savage en 1909 polinizando flores de 'Washington Navel' con polen de Poncirus trifoliata (Savage y Gadner, 1965). Se trata de un patrón tolerante a tristeza, psoriasis y xiloporosis, pero sensible a exocortis. Presenta sensibilidad al hongo Armillaria mellea y una resistencia moderada a Phytophthora spp. En cuanto a su comportamiento frente a las condiciones del medio es sensible a la caliza y a la salinidad. Posee buena compatibilidad con todas las variedades de naranjo dulce, mandarino y pomelo cultivadas en España y las variedades injertadas sobre citrange Carrizo presentan excelentes cosechas de elevada calidad comercial (Agustí, 2000).

Los patrones de cítricos presentan distintos efectos en relación con el tamaño que inducen en las variedades injertadas sobre ellos de modo que algunos patrones reducen el tamaño final del árbol. La utilización de patrones enanizantes o semienanizantes puede aportar ciertas ventajas como el aumento de la producción por unidad de superficie mediante plantaciones de alta densidad, la reducción de los costes del cultivo derivado de la poda, los tratamientos fitosanitarios y la recolección, la adaptación a pequeñas explotaciones y la posibilidad de mecanización del trabajo. Dada la difusión mayoritaria del portainjerto citrange Carrizo, la posibilidad de disponer de plantas de citrange Carrizo enanizantes o semi-enanizantes constituye un objetivo de gran interés.

\subsection{Mejora genética en cítricos}

La mejora genética de los cítricos, tanto de la variedad como del patrón, es muy costosa, principalmente por la superficie y el tiempo (20 años o más) necesarios para la evaluación en campo de las características agronómicas de las plantas mejoradas. Además, las características de la biología reproductiva de los cítricos, 
como la apomixis, la incompatibilidad sexual y la elevada heterocigosis dificultan la mejora del material vegetal. La apomixis es un fenómeno frecuente en los cítricos mediante el cual se producen embriones sin fecundación previa. Estos embriones se forman a partir de la nucela (embriones nucelares) y las semillas que los contienen originan plantas cuya constitución genética es idéntica a la de la madre. En las especies o variedades apomícticas se producen en el mismo rudimento seminal los dos procesos, sexual y asexual, formándose semillas que contienen un embrión zigótico y uno o varios nucelares. Frecuentemente, los embriones nucelares son más vigorosos que el zigótico, que en muchos casos no completa su desarrollo y aborta. La apomixis complica la selección de híbridos. Sin embargo, es un carácter apreciado para la propagación de patrones uniformes e idénticos a los parentales (Davies y Albrigo, 1994). Además, muchas especies presentan esterilidad total o parcial en óvulos y/o polen, lo que impide su uso como parentales en programas de mejora mientras que otras especies son sexualmente incompatibles, dificultando la obtención de híbridos. Finalmente, la mayoría de las especies de cítricos son muy heterocigóticas y producen una progenie sexual muy variable (Herrero et al, 1996).

Esta combinación de factores adversos ha dificultado los esfuerzos de mejora de los cítricos mediante los métodos de mejora tradicional, de modo que la mayoría de los cítricos de interés comercial son el resultado de mutaciones espontáneas en los árboles de campo. En este contexto, los abordajes de genómica funcional, con su potencial para aislar genes de interés agronómico, para generar marcadores moleculares y para caracterizar colecciones de germoplasma, entre otros, podrían contribuir al desarrollo de nuevos cultivares de cítricos adaptados a las condiciones ambientales y cuya producción pueda satisfacer las características deseadas por los consumidores (Forment et al, 2005).

\section{GENÓMICA FUNCIONAL DE PLANTAS}

La secuencia genómica de una planta permite comprender la base genética de las diferencias entre las plantas y otros eucariotas, y sienta los cimientos para la caracterización detallada de los genes que constituyen una planta. El primer genoma secuenciado en plantas fue el de Arabidopsis thaliana (Arabidopsis Genome Initiative, 2000), seguido por el de arroz (Goff et al, 2002; Yu et al, 2002; International Rice Genome Sequencing Project, 2005) y, recientemente, por el de Populus trichocarpa (Tuskan et al, 2006) y Vitis vinifera (Jaillon et al, 2007; Velasco et al, 2007). La secuenciación del genoma de otras especies vegetales de interés agronómico como trigo, maíz, soja, tomate, patata o naranjo, entre otras, se está llevando a cabo en la 
actualidad. En particular, el DOE Joint Genome Institute (JGI) ha iniciado un proyecto preliminar de secuenciación a baja cobertura de naranjo dulce (Citrus sinensis L. Osbeck). La interpretación de un genoma pasa por la anotación tanto a nivel estructural, con la identificación de los genes que lo integran, como a nivel funcional, con la asignación de funciones a dichos genes. La anotación de un genoma es un proceso dinámico e iterativo. Por ejemplo, el genoma de Arabidopsis continua siendo re-anotado por The Institute for Genomic Research (TIGR) desde que se completó (Haas et al, 2003; Wortman et al, 2003). Un punto crítico en la anotación de un genoma es la definición de la estructura de los modelos génicos, por ejemplo, del límite intrón-exón y de las regiones no traducibles. La construcción de los modelos génicos depende de la información procedente de las colecciones de ESTs (expressed sequence tags) y de secuencias de cDNA de longitud completa. Por otro lado, la anotación funcional de un genoma depende del uso de la bioinformática para inferir la función génica ya que sólo se dispone de resultados experimentales que pueden utilizarse en esta asignación para una proporción pequeña de los genes de un genoma (Rensink y Buell, 2005).

La secuenciación y anotación, tanto estructural como funcional, de un genoma es un proceso costoso lo que explica que dicho esfuerzo se haya llevado a cabo sólo en algunas especies vegetales. Sin embargo, la secuenciación de genotecas de cDNA y el análisis de las ESTs resultantes constituye el modo más directo de obtener información de un genoma a nivel del RNA, de modo que una de las aplicaciones más extendida de la genómica en plantas ha sido la generación de colecciones de ESTs.

\subsection{Colecciones de ESTs: herramientas para la identificación de genes, el análisis de la expresión génica y el desarrollo de marcadores moleculares}

Las ESTs constituyen la información de secuencia más abundante de los genomas de plantas, tanto en términos de número de secuencias como de cantidad total de nucleótidos. Las ESTs son secuencias parciales obtenidas de la secuenciación del extremo 5' y/o 3' de clones de cDNA aislados al azar (Adams et al, 1991). Una genoteca de cDNA contiene decenas de miles de clones que representan la porción transcrita de un genoma en una condición definida (un tejido, un estadio del desarrollo concreto y en respuesta a un determinado estímulo ambiental o una situación de estrés biótico o abiótico). A pesar de que una EST representa sólo una porción de la secuencia codificante (aproximadamente de 500 pb), la obtención masiva de estas secuencias parciales es de gran utilidad. La generación de una colección de ESTs constituye un método relativamente rápido y potente para la identificación de genes, 
para la confirmación de las regiones codificantes en secuencias genómicas, para el estudio de relaciones filogenéticas, para la estimación de los niveles de expresión de los genes de los que proceden y para el desarrollo de micromatrices de DNA. Adicionalmente, los proyectos de secuenciación de ESTs pueden llegar a identificar una proporción significativa del contenido génico de un organismo de modo que pueden suponer el inicio de proyectos de secuenciación de un genoma (Alba et al, 2004). Actualmente, la base de datos de ESTs del NCBI (National Center for Biotechnology Information) contiene más de 49 millones de ESTs, de las que más de 12 millones derivan de plantas (dbEST 11 enero 2008; http://www.ncbi.nlm.nih.gov/ dbEST/; Boguski et al, 1993). Las colecciones de ESTs más exhaustivas en plantas corresponden a la especie modelo Arabidopsis con 1.5 millones de ESTs, seguida de varios cereales fundamentales para la alimentación humana como arroz, maíz o trigo, con más de un millón de ESTs en cada caso.

Una de las aplicaciones iniciales de las colecciones de ESTs fue la identificación de nuevos genes implicados en rutas metabólicas específicas de las plantas, como genes relacionados con algunas modificaciones de los ácidos grasos, genes de la biosíntesis de isoprenoides o de la biosíntesis de la pared celular (revisado por Ohlrogge y Benning, 2000). En este sentido, una cuestión típica es cuáles son los genes que se expresan en una condición definida (tejido, estadio del desarrollo concreto y en respuesta a un determinado estímulo).

Aunque el primer propósito de la secuenciación de ESTs suele ser la caracterización de los genes de un organismo, una colección de ESTs puede aportar información sobre la expresión génica. Este aspecto del análisis de ESTs, llamado expresión digital, se basa en que si un gen $X$ tiene un nivel de expresión elevado (lo que implica niveles elevados de $m R N A_{x}$ ), el número de cDNAs obtenido a partir del $m R N A_{x}$ será alto en la genoteca realizada con el material vegetal en el que se expresa el gen $X$. Tras la secuenciación al azar de un gran número de clones de la genoteca de cDNA, la proporción de ESTs que corresponde al gen $X$ supondrá una estimación de la abundancia del mRNAx en la población original (Ohlrogge y Benning, 2000). Los análisis de expresión digital se apoyan en el desarrollo de métodos estadísticos robustos que permiten valorar la fiabilidad de la información obtenida (Audic y Claverie, 1997; Romualdi et al, 2003). El agrupamiento de los genes en función de su abundancia relativa en diferentes genotecas de cDNA permite obtener patrones de expresión génica de modo que los genes con perfiles de expresión similares en las diferentes condiciones estudiadas quedan agrupados. Además, los propios tejidos y/o condiciones estudiadas pueden agruparse en función de la expresión génica. En plantas, se han identificado genes diferencialmente expresados en distintos tejidos 
mediante el análisis de colecciones de ESTs en arroz (Ewing et al, 1999), patata (Ronning et al, 2003), trigo (Ogihara et al, 2003) y cebada (Zang et al, 2004). Asimismo, esta metodología se ha desarrollado para la identificación de genes relacionados con la maduración del fruto en tomate (Fei et al, 2004) y en manzano (Park et al, 2006) y con el desarrollo de la flor y del fruto en vid (da Silva et al, 2005). Además, la caracterización del gran número actual de colecciones de ESTs disponibles para multitud de plantas hace posible la comparación entre diferentes especies.

Las colecciones de ESTs constituyen también una valiosa herramienta para el desarrollo de marcadores moleculares, en particular en especies de interés agronómico para las que todavía no se dispone de la información derivada de la secuenciación del genoma. La selección asistida por marcadores moleculares constituye una estrategia clave en la mejora genética de plantas. Entre los marcadores moleculares que pueden desarrollarse a partir de ESTs destacan los polimorfismos de un solo nucleótido (SNPs, single-nucleotide polimorphisms) y las repeticiones de secuencia simple (SSRs, simple sequence repeats). Las posibles funciones de los genes en los que se encuentran los marcadores derivados de ESTs pueden deducirse por similitud de secuencia con bases de datos de proteínas (por ejemplo, Swissprot) (Varshney et al, 2005). Los marcadores moleculares derivados de sitios polimórficos en los genes responsables de la variación de los rasgos fenotípicos se denominan marcadores funcionales (FMs) (Andersen y Lübberstedt, 2003). Los FMs se han desarrollado en muchas especies vegetales para las que se dispone de datos de ESTs (Gupta y Rustgi, 2004). Rudd et al (2005) demostraron la viabilidad de la predicción de marcadores moleculares (SSRs, SNPs) en más de 50 especies vegetales a partir de los datos de ESTs (PlantMarkers, http://markers.btk.fi/). Recientemente, se han identificado posibles SSRs y SNPs mediante el análisis de colecciones de ESTs en manzano (Newcomb et al, 2006) y en melón (González-lbeas et al, 2007). La mayor ventaja de los FMs sobre otros marcadores generados a partir de regiones anónimas del genoma (RMs, random markers) es que están completamente ligados al rasgo de interés puesto que derivan del gen responsable de dicho carácter (Varshney et al, 2005).

Una colección de ESTs presenta ciertas limitaciones. El hecho de que las ESTs representen el conjunto de genes transcritos en unas determinadas condiciones implica que los genes con bajos niveles de expresión estarán poco representados en la colección de ESTs. La presencia de una EST constituye un atributo fiable mientras que su ausencia sólo permite concluir que en las condiciones a partir de las que se ha generado la colección de ESTs no ha sido posible detectar dicho transcrito 
(Rudd, 2003). Esta limitación de la representación génica de una colección de ESTs se ha abordado mediante estrategias de normalización y/o sustracción de las genotecas de cDNA, que permiten equilibrar la proporción relativa de transcritos comunes y raros (Bonaldo et al, 1996). Asimismo, la secuenciación de clones procedentes de diferentes genotecas de cDNA generadas en distintas condiciones (tejidos, estadios de desarrollo, respuesta a estrés) permite maximizar el conjunto de genes muestreados, mientras que la secuenciación exhaustiva de una sola genoteca de cDNA permitirá obtener transcritos con bajos niveles de expresión. Otras propiedades inherentes a las ESTs como la calidad de secuencia, la redundancia o la naturaleza parcial (aproximadamente de $500 \mathrm{pb}$ ) implican que su manejo dependa de numerosas herramientas bioinformáticas que, en último término, aportan un valor añadido a las colecciones de ESTs (revisado por Dong et al, 2005). En los últimos años se han desarrollado numerosas bases de datos de ESTs de plantas que han añadido la anotación funcional de las ESTs y que permiten seleccionar y obtener información sobre grupos de secuencias que satisfacen criterios de búsqueda específicos. Recientemente se ha creado la base de datos TA (TIGR Plant Transcript Assemblies, http://plantta.tigr.org), que se nutre de las secuencias de ESTs y cDNAs disponibles en la base de datos de nucleótidos GenBank del NCBI para la generación de un conjunto de transcritos ensamblados y anotados (Childs et al, 2007). La versión actual de la base de datos TA (versión 5) contiene más de 11 millones de ESTs procedentes de 254 especies vegetales.

\subsection{Micromatrices de DNA: la revolución del análisis de la expresión génica}

Los mayores avances tecnológicos para la medida de la expresión génica se han producido en la última década. En particular, la tecnología de las micromatrices ha revolucionado la biología molecular, de modo que actualmente es la más utilizada en experimentos de expresión génica de gran escala puesto que permite la detección simultánea de miles de transcritos a un coste razonable (Busch y Lohmann, 2007). La capacidad de medir la expresión génica de todos los genes de un organismo constituye un potente sistema analítico y la disponibilidad de la tecnología necesaria para ello ha abierto nuevas oportunidades a la comunidad científica (Meyers et al, 2004). La tecnología de las micromatrices se apoya en la existencia de colecciones de ESTs o datos de secuencia genómica (y, por tanto, está limitada por la disponibilidad de los mismos), en instrumentación robótica con capacidad de trabajo a muy pequeña escala y en compuestos fluorescentes para la detección simultánea de poblaciones de transcritos derivadas de diferentes muestras (Alba et al, 2004). Además, el conjunto 
masivo de datos generado en un experimento de análisis de la expresión génica mediante micromatrices ha presentado nuevos problemas estadísticos y analíticos que han supuesto la convergencia de la biología, las matemáticas y la bioinformática (Meyers et al, 2004).

Una micromatriz de DNA consiste en un conjunto de secuencias de DNA (sondas) inmovilizado sobre una superficie sólida y organizado en cuadrículas microscópicas mediante un sistema de robótica (Alba et al, 2004). Los datos de expresión génica se obtienen mediante la hibridación de la micromatriz con una población de RNA o cDNA, marcado con fluorescencia, que procede de la muestra problema, de modo que se obtiene una señal de fluorescencia para cada sonda, cuya intensidad representa el nivel de expresión de dicho gen en la muestra problema (Busch y Lohmann, 2007). Actualmente, se pueden distinguir tres tipos de micromatrices de DNA según la naturaleza de las sondas y las técnicas de hibridación utilizadas: 1) productos de PCR y 2) oligonucleótidos largos (50-70 bases), ambos hibridados con dos poblaciones de cDNA, marcadas diferencialmente, que derivan de dos condiciones experimentales (por ejemplo, muestra problema y muestra control) y 3) oligonucleótidos cortos (25 bases) sintetizados in situ e hibridados con una única población de cDNA (Busch y Lohmann, 2007). Desde el primer trabajo de análisis de la expresión génica mediante micromatrices (Schena et al, 1995), las basadas en productos de PCR han sido muy utilizadas debido a su flexibilidad y a su razonable coste de fabricación (Busch y Lohmann, 2007). Estas micromatrices se generan a partir de genotecas de cDNA por lo que dependen de la disponibilidad de colecciones de clones. Sin embargo, el hecho de que en la última década se hayan creado numerosas colecciones de clones de cDNA en plantas ha permitido el desarrollo de este tipo de micromatrices (Alba et al, 2004), sobre todo en especies de interés agronómico como arroz (Rabbani et al, 2003; Lian et al, 2006), maíz (Fernandes et al, 2002), trigo (Clarke y Rahman, 2005), soja (Vodkin et al, 2004; Ainsworth et al, 2006), patata (Ducreux et al, 2005; Stupar et al, 2007), tomate (Alba et al, 2005) y fresa (Aharoni et al, 2004b). Sin embargo, una limitación importante es que las diferentes sondas de la micromatriz presentan, con frecuencia, secuencias de DNA similares, lo que conlleva problemas de hibridación cruzada (Alba et al, 2004). Recientemente, el programa CATMA de Arabidopsis (Complete Arabidopsis Transcriptome Microarray) ha generado un conjunto estandarizado de amplicones diseñado para minimizar la similitud con cualquier otra secuencia y, por tanto, el problema de la hibridación cruzada. La micromatriz CATMA permite analizar la expresión de 18,981 genes mediante sondas específicas de 150-500 pb de longitud (Allemeersch et al, 2005). Por otro lado, las micromatrices de oligonucleótidos largos contienen un conjunto 
estandarizado de sondas de unas 60 bases diseñadas para representar genes únicos, minimizando el problema de la hibridación cruzada. Las principales limitaciones de estas micromatrices son la complejidad del proceso de diseño de los oligonucleótidos y el coste derivado de la síntesis de los mismos (Alba et al, 2004). La micromatriz de Agilent para Arabidopsis, que permite analizar la expresión de más de 40,000 unidades de transcripción, constituye un ejemplo de este tipo de micromatrices (http://www.chem.agilent.com). Por otro lado, algunas empresas, como Operon, producen conjuntos de oligonucleótidos para diferentes especies de plantas como Arabidopsis, arroz, maíz, vid o tomate (http://www.operon.com). Finalmente, las micromatrices de oligonucleótidos cortos sintetizados in situ, contienen conjuntos de oligonucleótidos de 25 bases de longitud sintetizados mediante fotolitografía. Actualmente, Affymetrix (http://www.affymetrix.com), con la patente de esta tecnología, produce micromatrices para un gran número de plantas como Arabidopsis, arroz, cebada, maíz, trigo, vid, tomate, Medicago, Populus y Citrus, entre otros (revisado por Rensink y Buell, 2005). El análisis de la expresión génica mediante micromatrices en plantas de interés agronómico permite identificar conjuntos de genes cuya expresión está correlacionada con el rasgo agronómico de interés estudiado.

\subsection{El Proyecto de Genómica Funcional de Cítricos (CFGP)}

El Proyecto de Genómica Funcional de Cítricos (CFGP; http://bioinfo.ibmcp. upv.es) surge fruto de la necesidad de dotar a la Citricultura actual de nuevas herramientas biotecnológicas que, por un lado, permitan profundizar en la comprensión de los mecanismos moleculares subyacentes a la biología de los cítricos, en particular de los relacionados con rasgos agronómicos de interés, y que, por otro lado, constituyan un sólido punto de apoyo en el desarrollo de futuros programas de mejora para la obtención de nuevas variedades. El CFGP se inicia en el año 2001 como una colaboración trilateral entre el Instituto de Biología Molecular y Celular de Plantas (IBMCP), el Instituto Valenciano de Investigaciones Agrarias (IVIA) y el Instituto de Agroquímica y Tecnología Alimentaria (IATA). La presente Tesis Doctoral se integra en el CFGP desde los orígenes del mismo.

En la actualidad existen diversas iniciativas de genómica funcional en cítricos, destacando los esfuerzos de secuenciación del genoma de cítricos (Roose et al, 2007; Chen y Gmitter, 2008; Terol y Talón, 2008); la secuenciación masiva de ESTs de cítricos (Machado et al, 2006; 2007); el desarrollo de la base de datos HarvEST (http://harvest.ucr.edu/), que recoge ESTs de diversas especies de interés agronómico, entre ellas cítricos (Close et al, 2007) y el de la micromatriz de 
oligonucleótidos cortos de Affymetrix (GeneChip ${ }^{\circledR}$ Citrus Genome Array), que representa 33,879 transcritos de cítricos (Close et al, 2006). Sin embargo, cuando se inició el CFGP la base de datos GenBank del NCBI contaba con apenas 2,000 secuencias de cítricos: 1,300 ESTs de frutos en desarrollo de Citrus unshiu, 300 secuencias de flavedo y albedo de frutos de pomelo y 200 secuencias de Citrus sinensis. Esto implica que el CFGP fue la primera aproximación genómica a gran escala iniciada en cítricos. El objetivo general del CFGP fue el desarrollo de herramientas genómicas para el estudio de procesos biológicos relevantes para la citricultura, desde la biología del desarrollo (desarrollo vegetativo, floración, cuajado, desarrollo y maduración del fruto, calidad del fruto, senescencia y abscisión), a la respuesta al estrés de origen tanto biótico (infección por virus y hongos) como abiótico (salinidad, sequía y deficiencia férrica), y a los procesos de post-cosecha (respuesta al frío y al ataque por hongos). Este objetivo general se concretó, inicialmente, con la construcción de 25 genotecas de cDNA que cubren un amplio rango de tejidos, estadios de desarrollo y condiciones de estrés biótico y abiótico, así como de una genoteca genómica de Citrus clementina. A partir de los clones generados se aislaron un total de 22,635 ESTs, que representaban 11,836 posibles transcritos únicos o unigenes de cítricos. Como un primer paso en la caracterización del transcriptoma de cítricos, 12,672 clones de cDNA, que representaban 6,875 posibles unigenes, se utilizaron para generar una micromatriz de cDNA de cítricos (Forment et al, 2005). Este trabajo fue pionero en genómica funcional de cítricos puesto que abordó, por primera vez, la secuenciación masiva de ESTs y la generación de una micromatriz de cDNA en cítricos. Posteriormente, se hicieron públicas otras colecciones de ESTs de cítricos (Fujii et al, 2006; Machado et al, 2006, 2007) y se puso al servicio de la comunidad científica la micromatriz de oligonucleótidos cortos de cítricos (Close et al, 2006). La micromatriz de cDNA generada por el CFGP (Forment et al, 2005) permitió el análisis de la expresión génica durante el desarrollo y la maduración del fruto en cítricos (Cercós et al, 2006) así como en relación a la respuesta a la infección del virus de la tristeza de los cítricos (Gandía et al, 2007). Recientemente, se ha generado una genoteca de cDNA normalizada de longitud completa y 9 genotecas de cDNA estándar a partir de tejidos y tratamientos de variedades y patrones seleccionados en relación a la calidad del fruto, la resistencia a la abscisión y la tolerancia a la salinidad. A partir de estas últimas genotecas se han aislado y anotado funcionalmente 52,626 ESTs de cítricos, que representan 15,664 unigenes. El análisis funcional de los unigenes de cítricos se ha centrado en rutas metabólicas tanto del metabolismo primario como secundario, con especial detalle en la biosíntesis de lignina en cítricos y en distintos aspectos de genómica comparada entre cítricos y Arabidopsis como la identificación 
de posibles ortólogos y la caracterización de familias génicas (Terol et al, 2007). En la actualidad el CFGP dispone de un total de 52 genotecas de cDNA (30 genotecas estándar, 6 genotecas de sustracción y 16 genotecas de longitud completa) generadas a partir de un amplio rango de condiciones (tejidos, estadios de desarrollo, condiciones de estrés biótico y abiótico) con el objeto de que la colección de ESTs derivada de estas genotecas maximice la representación del transcriptoma de los cítricos. En estos momentos, la colección de ESTs del CFGP consta de 85,965 ESTs agrupadas en 27,551 unigenes (11,844 contigs, o conjuntos de secuencias formados por dos o más ESTs y 15,707 singletons o secuencias únicas) que se gestionan en la base de datos EST2uni (Forment et al, 2008) (http://bioinf.comav.upv.es/est2uni), herramienta bioinformática desarrollada en el CFGP, que permite el pre-procesado, el ensamblaje y la anotación de las ESTs. Los contigs formados por un elevado número de ESTs, aunque aumentan la redundancia de una colección de ESTs, son de gran utilidad para la identificación de posibles marcadores moleculares, en particular SSRs y SNPS. EI análisis de la colección de ESTs de cítricos del CFGP, mediante EST2uni, ha permitido identificar 1,533 posibles SSRs y 6,139 posibles SNPs en cítricos (http://bioinf.comav.upv.es/est2uni). La identificación de este conjunto de posibles marcadores moleculares en cítricos constituye una herramienta fundamental a partir de la cual se pueden desarrollar posteriores estudios que aborden los problemas concretos de la taxonomía, las relaciones filogenéticas y la variabilidad genética del género Citrus, cuestiones críticas en la caracterización del germoplasma, en el control de la erosión genética, en el registro de nuevas variedades y en el establecimiento de nuevos programas de mejora genética.

\section{APROXIMACIÓN GENÓMICO-FUNCIONAL A DIVERSOS ASPECTOS DEL DESARROLLO VEGETATIVO EN CÍTRICOS}

\subsection{Biosíntesis de isoprenoides y flavonoides}

\subsubsection{Biosíntesis de isoprenoides}

Los isoprenoides (o terpenoides) constituyen el grupo funcional y estructuralmente más variado de metabolitos en las plantas (Croteau et al, 2000). Los esteroles (isoprenoides con un esqueleto C30) son componentes esenciales de las membranas; carotenoides (C40) y clorofilas (que contienen una cadena lateral C20) actúan como pigmentos fotosintéticos; plastoquinona y ubiquinona (que contienen largas cadenas laterales de isoprenoides) participan en el transporte electrónico; el 
isopreno (C5) es un producto volátil que liberan los tejidos fotosintéticamente activos y que participa en la formación del ozono troposférico; giberelinas (C20), brasinosteroides (C30) y ácido abscísico (C15) son fitohormonas derivadas de isoprenoides y algunos monoterpenos (C10), sesquiterpenos (C15) y diterpenos (C20) están implicados en procesos de defensa (Lange y Ghassemian, 2003). La biosíntesis de los isoprenoides comienza con la formación de isopentenil difosfato (IPP, C5) y dimetilalil difosfato (DMAPP, C5). En plantas, la síntesis de estas unidades C5 se produce mediante dos rutas localizadas en diferentes compartimentos celulares: la ruta citosólica del mevalonato (MVA) y la ruta plastidial del metileritritol fosfato (MEP) (Fig. 1). El IPP derivado de la ruta del MVA puede ser transportado a la mitocondria para producir isoprenoides mitocondriales. Los isoprenoides derivados de la ruta del MVA son ubiquinonas, esteroles (incluidos los brasinosteroides), sesquiterpenos, politerpenos y dolicoles. A partir de la ruta plastidial del MEP se sintetizan otros isoprenoides como plastoquinonas, filoquinonas, clorofilas, tocoferoles, giberelinas, carotenoides, ácido abscísico y monoterpenos (Fig. 1).

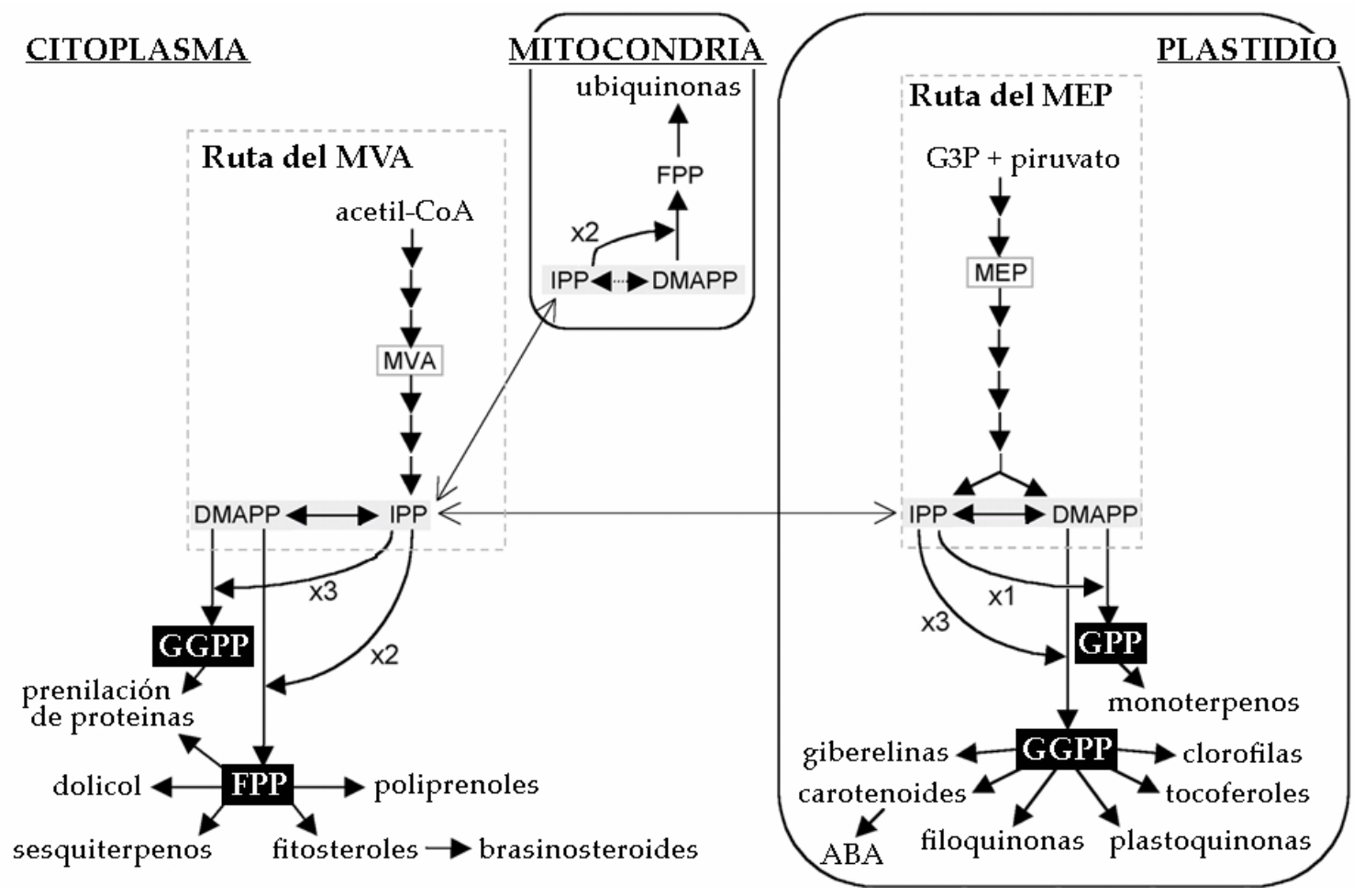

Fig. 1. Biosíntesis de isoprenoides en plantas. La formación de IPP y DMAPP se produce mediante la ruta citosólica del MVA y la ruta plastidial del MEP. Además, se señalan los metabolitos derivados de la ruta del MVA, cuya síntesis se produce en el citosol, y los derivados del MEP que se sintetiza, al menos en parte, en el plastidio. 
Los cítricos constituyen una fuente importante de metabolitos derivados de isoprenoides, como carotenoides, relacionados con el color del fruto y con propiedades nutricionales como precursores de vitamina A y antioxidantes; limonoides, implicados en el sabor del fruto y con valor como anticancerígenos; y mono- y sesquiterpenos, relacionados con el sabor de los frutos y con el aroma, de frutos y de hojas. Los carotenoides se acumulan en el fruto durante su maduración, especialmente en el flavedo (o parte más externa de la corteza) que es una de las fuentes más ricas y complejas de carotenoides en plantas (revisado por Rodrigo y Zacarías, 2006). En particular, el fruto de los cítricos constituye un material de gran interés para el estudio de la acumulación de xantofilas (carotenoides oxigenados) pues esta acumulación masiva no sucede en otras especies como tomate o Arabidopsis. La relación entre la acumulación de carotenoides y la expresión de los genes implicados en su biosíntesis ha sido estudiada con detalle durante la maduración del fruto en tres variedades de cítricos con diferente composición en carotenoides por Kato et al (2004). Los resultados obtenidos demostraron que la acumulación de carotenoides durante la maduración de los frutos es un proceso específicamente regulado por la expresión coordinada de los diferentes genes de biosíntesis de carotenoides (Kato et al, 2004). Los aceites esenciales son las fracciones líquidas volátiles que contienen las sustancias responsables del aroma de las plantas. En los cítricos constituyen uno de los principales productos y se obtienen tanto de la corteza del fruto, mediante presión en frío, como de las hojas, por destilación en corriente de vapor. Los aceites esenciales, además de ser responsables en gran medida del aroma y del sabor percibido por los consumidores, son valiosos desde el punto de vista industrial para la obtención de fragancias, fármacos y productos agroquímicos (revisado por Rodrigo y Zacarías, 2006). Los constituyentes volátiles de los aceites esenciales de cítricos son, fundamentalmente, mono- y sesquiterpenos. La composición de los aceites esenciales varía mucho entre especies, variedades e, incluso para un mismo cultivar, entre la piel del fruto y las hojas. Así, la fracción volátil de los aceites esenciales de la piel de frutos de Citrus clementina (especie a partir de la que se han generado la mayor parte de ESTs del CFGP) está compuesta por limoneno (90\%), sabineno (<4\%) y mirceno $(<2 \%)$, mientras que los aceites esenciales más importantes de las hojas son sabineno (45\%) y linalool (20\%) (Lota et al, 2001). Esta variabilidad parece deberse principalmente a la expresión de diferentes terpeno sintasas, enzimas clave en la biosíntesis de mono-, sesqui- y diterpenos. En los últimos años se han aislado y caracterizado algunos genes que codifican terpeno sintasas del género Citrus, tanto monoterpeno sintasas, como limoneno sintasa, $\beta$-pineno y $\gamma$-terpineno sintasa de Citrus limon (Lücker et al, 2002) y de Citrus unshiu (Shimada et al, 2004), como 
sesquiterpeno sintasas, como $\beta$-farneseno sintasa de Citrus junus (Maruyama et al, 2001) y valenceno sintasa de Citrus sinensis (Sharon-Asa et al, 2003). Sin embargo, dado que los aceites esenciales de los cítricos presentan una gran variedad de monoy sesquiterpenos, cabe esperar que la síntesis de estos compuestos esté catalizada por otras terpeno sintasas todavía no identificadas en cítricos.

A pesar de los trabajos realizados en la caracterización de la biosíntesis de carotenoides (Kato et al, 2004) y de diversas terpeno sintasas en cítricos (Lücker et al, 2002; Maruyama et al, 2001; Sharon-Asa et al, 2003; Shimada et al, 2004), la mayor parte de las rutas de biosíntesis de metabolitos derivados de isoprenoides todavía no se han estudiado en este género. La colección de ESTs de cítricos generada por el CFGP constituye una herramienta de gran interés para la identificación de los genes implicados en las diferentes rutas del metabolismo de isoprenoides, incluyendo la búsqueda de genes que codifican otras terpeno sintasas en cítricos.

\subsubsection{Biosíntesis de flavonoides}

Los flavonoides constituyen un grupo importante de metabolitos secundarios en las plantas que están implicados en diversas funciones como la protección frente a la radiación UV, la pigmentación de las flores para atraer a los polinizadores, la germinación del polen, la resistencia al ataque por microorganismos y la defensa frente a insectos (Croteau et al, 2000). Además, los flavonoides poseen un amplio rango de actividades bioquímicas y farmacológicas en mamíferos y otros sistemas biológicos, por lo que constituyen un grupo de potenciales agentes terapéuticos (Middleton et al, 2000). Los cítricos acumulan grandes cantidades de flavonoides, tanto en los frutos como en las hojas, especialmente flavanonas que son parcialmente responsables del aroma y del sabor del fruto. Además, los cítricos son un componente importante de la dieta por sus propiedades antioxidantes, antiinflamatorias, antialérgicas y supresoras de mutagénesis, de modo que constituyen una fuente importante de flavonoides para las industrias agroalimentarias y farmacéuticas (Manthey et al, 2001).

La biosíntesis de flavonoides ha sido muy estudiada en plantas y los genes implicados en esta ruta han sido aislados y caracterizados en diversas especies vegetales (revisado por Winkel-Shirley, 2001; Ververidis et al, 2007). La biosíntesis de flavonoides comienza con la formación de la flavanona naringenina en dos pasos consecutivos catalizados por las enzimas chalcona sintasa (CHS) y chalcona isomerasa ( $\mathrm{CHI}$ ) (Fig. 2). Posteriormente, la naringenina puede ser hidroxilada para formar el flavanol dihidroxikaempferol, reacción catalizada por la enzima flavanona 
3-hidroxilasa $(\mathrm{F} 3 \mathrm{H})$. En cítricos se han aislado los genes que codifican estos tres pasos iniciales de la biosíntesis de flavonoides (Moriguchi et al, 1999; Moriguchi et al, 2001). El análisis de la expresión génica de estos genes mostró una mayor expresión en las etapas iniciales del desarrollo del fruto, correlacionada con la acumulación de flavonoides (Moriguchi et al, 2001). La conversión de flavanol (como el dihidroxikaempferol) en flavonol (como el kaempferol) está catalizada por flavonol sintasa (FLS). En cítricos, se ha aislado el gen que codifica FLS (Moriguchi et al, 2002) y se ha caracterizado su actividad enzimática (Wellmann et al, 2002). Por otro lado, la flavanona naringenina puede sufrir dos glucosilaciones sucesivas: la primera catalizada por 7-O-glucosiltransferasa y la segunda por una rhamnosiltransfersa (Fig. 2). En cítricos, se ha aislado y caracterizado funcionalmente el gen Cm1,2RhaT, que codifica una 1,2 rhamnosiltransferasa (Frydman et al, 2004).

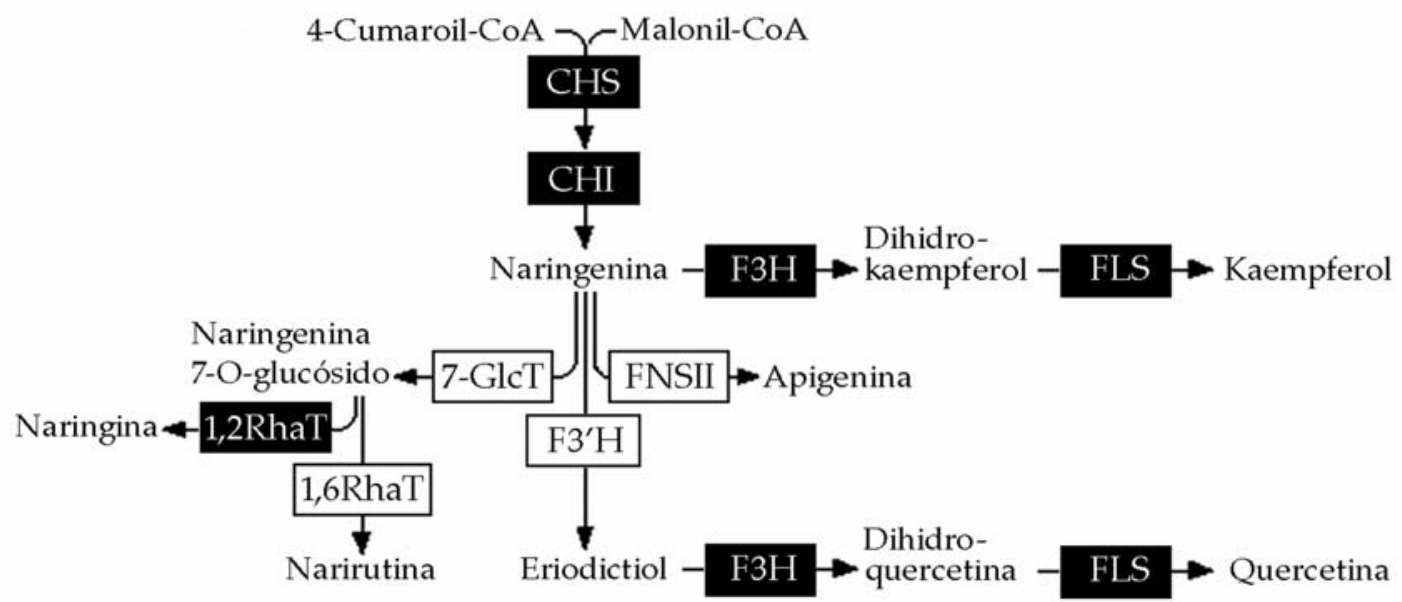

Fig. 2. Biosíntesis de flavonoides en cítricos. Las cajas negras señalan los pasos para los que se han aislado los correspondientes genes en cítricos y las cajas blancas aquellos pasos que todavía continúan sin caracterización molecular en cítricos.

En los últimos años se han caracterizado diversos genes implicados en la biosíntesis de flavonoides en cítricos. Sin embargo, los genes que codifican algunos pasos fundamentales, como la formación de flavonas (ej. apigenina) todavía no han sido aislados. La identificación de estos genes a partir de la colección de ESTs del CFGP debe aportar un mayor conocimiento de la biosíntesis de flavonoides en cítricos y, adicionalmente, supone una herramienta básica con la que abordar la fisiología, la bioquímica y la regulación genética del metabolismo de flavonoides en este género. 


\subsection{Mapas de expresión génica en plantas}

Todos los organismos eucariotas complejos, incluidas las plantas superiores, están formados por distintos tipos celulares organizados en tejidos y órganos. El conjunto de tejidos y órganos de un organismo concreto se genera a lo largo de su ciclo de vida a través de un proceso, regulado temporal y espacialmente, de expresión selectiva de fracciones específicas del mismo genoma en diferentes células (Meyerowitz 2002). Uno de los objetivos de la biología del desarrollo es definir el subconjunto de genes expresado y su abundancia relativa en cada órgano y tipo de tejido. Las plantas superiores siguen un proceso de desarrollo relativamente simple, con menos de 25 tejidos y tipos celulares principales, por lo que suponen un buen modelo para definir los patrones de expresión génica específicos de cada órgano y tipo de tejido (Ma et al, 2005). El análisis de la expresión génica en multitud de tejidos y estadios de desarrollo puede conducir a la creación de un atlas de expresión génica con el que describir los patrones de expresión de los genes de un organismo. La generación de dicho atlas transcripcional constituye una herramienta de gran utilidad pues permite conocer tanto el patrón de expresión de un grupo de genes de interés como el conjunto de genes que se ajusta a un patrón de expresión definido. En este sentido, resulta posible inferir la función de un grupo de genes bajo la suposición de que los genes con un patrón de expresión similar están implicados en procesos similares (Borevitz y Ecker, 2004). El desarrollo de la tecnología de micromatrices de DNA, que permiten medir la expresión de miles de genes simultáneamente, proporciona un método eficaz para analizar el conjunto de genes que se expresa en un órgano o en un tipo de tejido. En los últimos años, diversos trabajos han abordado el análisis de los patrones de expresión génica en diferentes órganos mediante micromatrices, especialmente en Arabidopsis. Ma et al (2005) analizaron la expresión génica en 18 órganos o tipos de tejidos que representaban diferentes aspectos del ciclo de vida de Arabidopsis. Sin embargo, el conjunto de datos de expresión más completo es el de Schmid et al (2005) que forma parte del consorcio AtGenExpress (http://www.arabidopsis.org/info/expression/ATGenExpress.jsp). Este trabajo analizó la expresión de 22,000 genes de Arabidopsis, utilizando la micromatriz ATH1 (Redman et al, 2004), en 79 muestras que cubren diversos estadios de desarrollo, desde la embriogénesis hasta la senescencia, y diversos órganos. Los resultados obtenidos representan el estado transcripcional subyacente al programa de desarrollo de la planta y revelan ciertos aspectos de interés. Por ejemplo, los perfiles de expresión génica muestran que, en general, la identidad de órgano domina sobre el estado de desarrollo o las condiciones ambientales, que constituyen componentes menores. 
Además, la anotación funcional mediante ontologías génicas muestra que los órganos que son morfológicamente similares contienen ontologías génicas similares (Schmid et al, 2005). Contrariamente a otros trabajos previos (Czechowski et al, 2004), los resultados obtenidos por Schmid et al (2005) muestran que la expresión de los genes que codifican factores de transcripción y componentes de señalización es similar al nivel de expresión promedio del genoma completo.

Recientemente, diversos trabajos han abordado la obtención de mapas transcripcionales a un nivel de resolución superior mediante el análisis de la expresión génica en tipos celulares específicos (revisado por Galbraith y Birnbaum, 2006). Los trabajos del grupo de Philip Benfey (Birnbaum et al, 2003; Nawy et al, 2005; Brady et al, 2007) han aportado un exhaustivo mapa transcripcional para casi todos los tipos celulares de la raíz de Arabidopsis. Los distintos tipos celulares se han aislado obteniendo diferentes líneas transgénicas en las que cada población celular se encuentra marcada con fluorescencia. Se aislan los protoplastos de la raíz de estas líneas y las células marcadas con fluorescencia se separan utilizando fluorescenceactivated cell sorter (FACS) (Birnbaum et al, 2005). Por otro lado, la microdisección por láser permite separar células individuales o grupos celulares a partir de tejidos intactos y esta técnica se ha utilizado para analizar la expresión génica durante el proceso de embriogénesis en Arabidopsis (Casson et al, 2005; Spencer et al, 2007).

La elaboración de mapas de expresión génica de diversos órganos, tejidos 0 células en plantas define e identifica el estado de dicho órgano, tejido o célula a nivel molecular lo que permite profundizar en la comprensión de sus funciones. Adicionalmente, las regiones promotoras de los genes diferencialmente expresados en cada órgano, tejido o célula constituyen una herramienta biotecnológica de interés para dirigir la expresión génica a los mismos.

\subsection{Control del desarrollo vegetativo: giberelinas}

\subsubsection{Metabolismo de giberelinas}

Las giberelinas (GAs) constituyen un grupo de hormonas vegetales que controlan diversos aspectos del desarrollo como la germinación, la expansión de las hojas, la elongación del tallo y de la raíz, el tiempo de floración y el desarrollo de la flor y del fruto (Sponsel y Hedden, 2004; Swain y Singh, 2005). La aplicación de GAs y de inhibidores de su biosíntesis es una práctica ampliamente utilizada en la agricultura, por ejemplo para estimular el crecimiento de los frutos en las variedades de uva sin semillas, para retrasar la senescencia del fruto en naranjas y limones, para aumentar 
el cuajado en mandarinas, manzanas y peras, para aumentar la elongación del tallo en la caña de azúcar o para disminuir el crecimiento de diversas especies como algodón y manzano (Hedden y Phillips, 2000a). El metabolismo de GAs ha sido estudiado en profundidad y está bien caracterizado (Hedden y Phillips, 2000b; Olszewski et al, 2002; Sponsel y Hedden, 2004). Las GAs se sintetizan a partir del precursor común geranilgeranil difosfato mediante la acción de tres grupos de enzimas (Fig. 3): 1) dos diterpeno sintasas, copalil difosfato sintasa (CPS) y ent-kaureno sintasa (KS), conducen a la formación de ent-kaureno; 2) dos monooxigenasas dependientes de citocromo P450, ent-kaureno oxidasa (KO) y ácido ent-kaurenoico oxidasa (KAO), catalizan la conversión de ent-kaureno en $\mathrm{GA}_{12}$ y $\mathrm{GA}_{53}$; y 3 ) dioxigenasas dependientes de 2-oxoglutarato, metabolizan $\mathrm{GA}_{12}$ y $\mathrm{GA}_{53}$ en diferentes GAs.

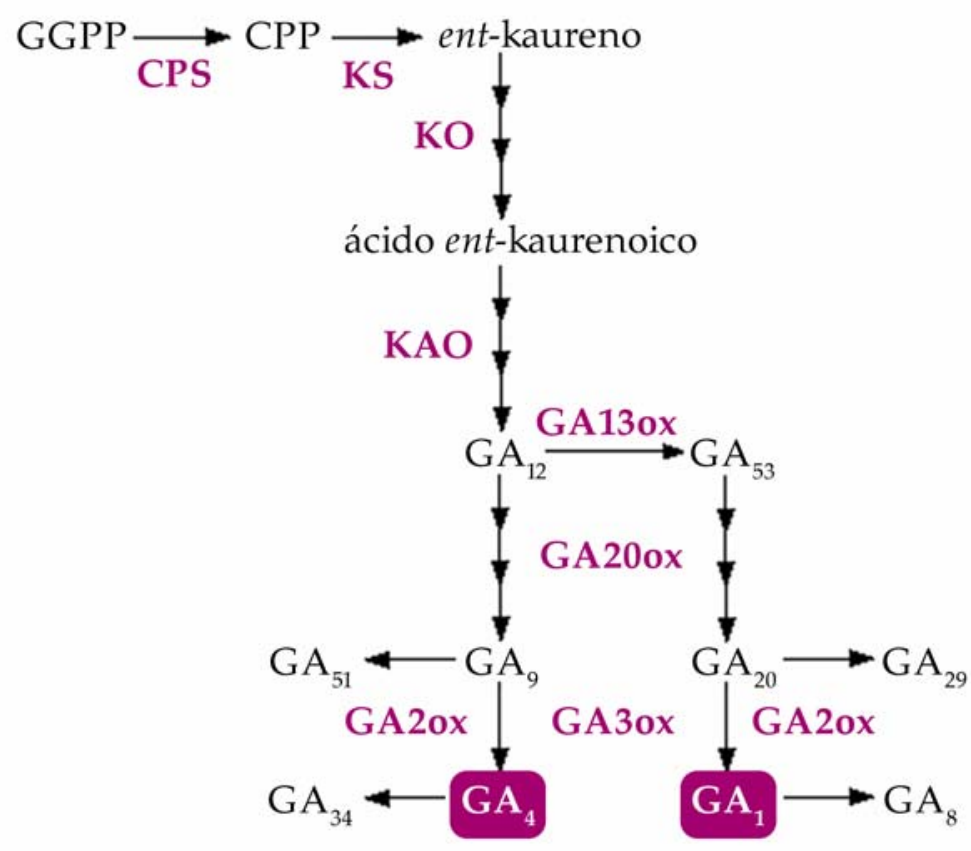

Fig. 3. Esquema del metabolismo de GAs. GGPP, geranilgeranil difosfato; CPP, copalil difosfato; CPS, copalil difosfato sintasa; KS, ent-kaureno sintasa; KO, ent-kaureno oxidasa; $\mathrm{KAO}$, ácido ent-kaurenoico oxidasa; GA13ox, GA 13-oxidasa; GA20ox, GA 20-oxidasa; GA3ox, GA 3-oxidasa; GA2ox, GA 2-oxidasa. Las GAs activas están marcadas en cajas.

El grupo de las dioxigenasas dependientes de 2-oxoglutarato incluye las enzimas GA 20-oxidasas (GA20ox) y GA 3-oxidasas (GA3ox), que actúan consecutivamente para producir las $G A s$ bioactivas $\left(G_{1}\right.$ y $\left.G A_{4}\right)$ a través de dos rutas paralelas: la ruta de la hidroxilación temprana en C-13 (que conduce a la formación de $\mathrm{GA}_{1}$ ) y la ruta de la no hidroxilación en C-13 (mediante la que se sintetiza GA $\mathrm{A}_{4}$ ) (Fig. 3). Una tercera clase de dioxigenasas, GA 2-oxidasas (GA2ox), inactivan tanto las GAs bioactivas $\left(\mathrm{GA}_{1}\right.$ y $\left.\mathrm{GA}_{4}\right)$ como sus precursores $\left(\mathrm{GA}_{20}, \mathrm{GA}_{9}, \mathrm{GA}_{12}\right.$ y $\left.G A_{53}\right)$. En cítricos, la 
principal ruta de síntesis de GAs es la ruta de la hidroxilación temprana en C-13, tanto en los tejidos vegetativos (Poling y Maier, 1988; Turnbull, 1989) como en los reproductivos (Goto et al, 1989; Talón et al, 1990; Talón et al, 1992; Ben-Cheikh et al, 1997b) de modo que $\mathrm{GA}_{1}$ es la GA bioactiva mayoritaria en cítricos. La mayoría de los genes que codifican las enzimas del metabolismo de giberelinas han sido aislados en diversas especies (Hedden y Kamiya, 1997; Hedden y Phillips, 2000b; Olszewski et al, 2002; Sponsel y Hedden, 2004). Las dioxigenasas constituyen pequeñas familias multigénicas cuyos miembros muestran distintos patrones de expresión regulados por diversos factores, tanto endógenos como ambientales (Kamiya y García-Martínez, 1999; Yamaguchi y Kamiya, 2000). La expresión de los genes que codifican estas dioxigenasas está sujeta a una regulación negativa (GA20ox y GA3ox) o positiva (GA2ox) por las GAs activas (Hedden y Phillips, 2000b).

\subsubsection{Modificación de la arquitectura de las plantas mediante cambios en los niveles de GA 20-oxidasas}

El importante incremento de la producción agrícola que se produjo durante la llamada 'Revolución Verde' fue posible por la introducción de variedades semi-enanas de alto rendimiento de trigo y arroz, en combinación con la aplicación de grandes cantidades de fertilizantes nitrogenados y pesticidas (Hedden, 2003). La fertilización nitrogenada es esencial para el aumento de la producción de grano pero promueve la elongación del tallo y el consecuente encamado de los cereales. Sin embargo, las variedades semi-enanas de la 'Revolución Verde' mostraron un mayor rendimiento y menores problemas de encamado bajo condiciones de elevada fertilización (Sakamoto y Matsuoka, 2004). La identificación de las mutaciones responsables del hábito de crecimiento semi-enano de las variedades de trigo y arroz de la 'Revolución Verde' ha mostrado que los genes afectados están implicados en la transducción de señal (proteínas DELLA) y en la ruta de biosíntesis de GAs (Hedden, 2003). En particular, la mutación sd1, responsable del carácter semi-enano de los cultivares de arroz utilizados durante la 'Revolución Verde' (como IR8), afecta a un gen que codifica una GA 20-oxidasa que se expresa en el tallo (Monna et al, 2002; Sasaki et al, 2002; Spielmeyer et al, 2002). Estos trabajos ponen de manifiesto el importante papel de las GAs en la regulación de procesos del desarrollo críticos para la agricultura.

En numerosas especies vegetales se ha demostrado que la sobre-expresión de los genes que codifican GA20ox implica una alteración de la concentración de GAs bioactivas, lo que indica que estos genes tienen un papel muy importante en la regulación de los últimos pasos de la ruta de biosíntesis de GAs. En este sentido, la 
generación de plantas transgénicas que sobre-expresan GA20ox ha sido descrita en diversas especies vegetales como Arabidopsis (Huang et al, 1998; Coles et al, 1999), álamo (Eriksson et al, 2000), tabaco (Vidal et al, 2001), manzano (Bulley et al, 2005) y, más recientemente, en el patrón de cítricos citrange Carrizo (Fagoaga et al, 2007). En Arabidopsis, la sobre-expresión de GA20ox condujo a la formación de hipocotilos más largos, elongación del tallo y adelanto de la floración, asociado con un aumento del contenido de GAs bioactivas respecto al control (Huang et al, 1998; Coles et al, 1999). Por el contrario, la expresión en antisentido de GA20ox dio como resultado plantas de Arabidopsis de altura y contenido en $\mathrm{GA}_{4}$ reducidos (Coles et al, 1999). Estos resultados demostraron que los niveles de GAs y, consecuentemente, el crecimiento y desarrollo de las plantas, podía ser modulado mediante la modificación de la expresión de los genes que codifican GA20ox, y abrieron un camino para la manipulación biotecnológica de la arquitectura de las plantas mediante la alteración del metabolismo de GAs. En el caso del álamo, Eriksson et al (2000) describieron que la sobreexpresión del gen de Arabidopsis AtGA20ox1 no sólo producía niveles elevados de GAs activas y un mayor crecimiento de las plantas, sino que, además, estas plantas tenían más biomasa y un mayor número y longitud de fibras xilemáticas, caracteres deseables en la producción de papel. En manzano, se ha aislado un fragmento de un gen que codifica GA20ox (MpGA20ox1) y se ha sobre-expresado en sentido y en antisentido en la variedad Greensleeves (Bulley et al, 2005). En este caso, la co-supresión del gen endógeno produjo plantas enanas, con un número y longitud de entrenudos reducido y un área de la hoja reducida, como resultado de un menor contenido en $\mathrm{GA}_{1}$ (Bulley et al, 2005). En cítricos se ha aislado un gen que codifica GA200x (CcGA200x1) a partir del portainjertos citrange Carrizo (Vidal et al, 2003). Recientemente, se han generado plantas transgénicas de citrange Carrizo que sobre-expresan el gen CCGA20ox1 en sentido y en antisentido (Fagoaga et al, 2007). Las líneas de sobre-expresión del gen CCGA200x1 en sentido mostraron una altura mayor debido a entrenudos más largos, mayor longitud de las espinas (órganos típicos de los cítricos en el estadio juvenil), menor área foliar y menor diámetro de los tallos, debido a una disminución en el área del xilema, caracteres asociados con un aumento de 2-3 veces del contenido de $\mathrm{GA}_{1}$ en brotes jóvenes en desarrollo (Fagoaga et al, 2007). Por otro lado, la sobre-expresión en antisentido del gen CCGA20ox1 dio lugar a plantas con una altura ligeramente inferior, menor longitud de las espinas y un porte arbustivo, más ramificado, relacionado con un menor contenido en $\mathrm{GA}_{1}$ (Fagoaga et al, 2007). Todos estos trabajos han demostrado que la actividad GA 20-oxidasa es determinante para la producción de GAs en las plantas y que, por tanto, constituye una buena diana para la manipulación genética de la biosíntesis de GAs. En particular, en 
frutales como manzano y cítricos, la posibilidad de obtener portainjertos con un efecto enanizante, mediante la reducción del contenido de GAs bioactivas, aportaría considerables beneficios al permitir una mayor densidad de plantación, un manejo del cultivo más sencillo y al facilitar la recogida mecánica de los frutos, reduciendo con todo ello los costes de producción.

La percepción de GAs y la ruta de transducción de señal convierten la señal de GAs en cambios en la expresión génica y en la morfología de la planta (Sun y Gubler, 2004; Schwechheimer, 2008). Por tanto, cabe esperar que el fenotipo observado en las plantas transgénicas con el metabolismo de GAs modificado esté asociado con cambios importantes en la expresión génica. La tecnología de micromatrices permite examinar los cambios en los niveles de expresión de miles de genes en un solo experimento. Sin embargo, existe poco trabajo de este tipo en la literatura utilizando transgénicas con el metabolismo de GAs modificado. En este sentido, se ha descrito el análisis del transcriptoma del xilema en desarrollo de plantas transgénicas de álamo (Populus tremula L. x tremuloides Michx.) que sobre-expresan el gen AtGA20ox1 de Arabidopsis (Israelsson et al, 2003). En este caso, se observa una inducción de los genes implicados en la formación y extensión de la pared celular (como pectin metil esterasa, pectato liasa, celulasa, endoglucanasas y expansinas) asociado con el mayor número y longitud de fibras xilemáticas observado en estas plantas transgénicas (Eriksson et al, 2000). Sin embargo, este estudio transcripcional examinó sólo un grupo de genes pues utilizó una micromatriz de DNA que contiene 2,995 ESTs procedentes de una genoteca de cDNA de floema, cambium y xilema en desarrollo de Populus tremula L. x tremuloides Michx. (Sterky et al, 1998).

\subsubsection{Identificación de genes de respuesta temprana a GAs}

La mejora del conocimiento del papel de las GAs en la regulación del crecimiento y desarrollo de la planta requiere la identificación de los genes de respuesta temprana a GAs, es decir, aquellos cuya expresión está alterada antes de que se produzca ningún cambio morfológico. La identificación de genes regulados por GAs se ha abordado con diversas estrategias, como la hibridación substractiva (Phillips y Huttlu, 1994) o differential display (van der Knaap et al, 1997). Recientemente, se han descrito algunos trabajos en los que se analizan los cambios producidos en la expresión génica tras la aplicación de GAs en arroz y Arabidopsis utilizando micromatrices. En arroz, la respuesta transcripcional a GAs se ha estudiado en callos (Yazaki et al, 2004) y en plántulas (Yang et al, 2004). El trabajo de Yazaki et al (2004) identificó genes regulados por GAs tras el cultivo de callos de arroz 
durante 3 días en GAs (Yazaki et al, 2004). Entre los genes inducidos se encontraron genes implicados en la división y diferenciación celular y en defensa (Tabla Suplementaria II). Yang et al (2004) estudiaron los cambios de expresión génica en plántulas de arroz tras la aplicación durante 24 horas de $\mathrm{GA}_{3}$. Los resultados obtenidos por ambos grupos no coinciden totalmente. Sin embargo, la expresión de los genes que codifican xiloglucano endotransglicosilasa (XET) apareció inducida por GAs en los dos trabajos, sugiriendo que las GAs tienen un papel en la regulación de la elongación y la organización de la pared celular (Tabla Suplementaria II). En Arabidopsis, se ha examinado el efecto de las GAs sobre la expresión génica en semillas en germinación (Ogawa et al, 2003; Cao et al, 2006), en plántulas (Zentella et al, 2007) y en flores (Cao et al, 2006). Los experimentos realizados en Arabidopsis han aprovechado la ventaja de disponer de mutantes con defectos en la ruta de biosíntesis de GAs. En concreto, el mutante ga1-3, que muestra una deficiencia severa de GAs, ya que el gen GA1 codifica una copalil difosfato sintasa (CPS) que cataliza el primer paso de la biosíntesis de GAs (Sun y Kamiya, 1994) (Fig. 3). Este mutante es extremadamente enano y presenta un retraso en la floración y esterilidad masculina (Koornneef y van der Veen, 1980; Wilson et al, 1992), defectos que se rescatan completamente tras la aplicación exógena de GA. El trabajo de Ogawa et al (2003) identificó 357 genes regulados por GAs durante la germinación (230 inducidos y 127 reprimidos), analizando semillas del mutante ga1-3 tras el tratamiento con GA durante 3, 6 y 12 horas (Tabla Suplementaria II). Los genes inducidos por GAs incluyeron aquéllos implicados en el metabolismo de la pared celular (elongación celular) y en la división celular. Asimismo se encontraron modulados por GAs diversos genes relacionados con otras hormonas vegetales (Ogawa et al, 2003). Posteriormente, Cao et al (2006) compararon los patrones de expresión génica en semillas embebidas y flores en desarrollo del mutante ga1-3 y del control, obteniendo 1,112 genes expresados diferencialmente en las semillas embebidas y 1,248 en las flores en desarrollo (Tabla Suplementaria II). Los resultados mostraron que las GAs regulan diferentes conjuntos de genes con funciones similares, o diferentes miembros de la misma familia génica, en el control de la germinación y del desarrollo floral. El análisis de ontologías de los genes expresados diferencialmente en cada tejido mostró la implicación de los mismos en los procesos de elongación celular, biogénesis y modificación de la pared celular, fosforilación y defosforilación de proteínas, señalización por ABA y auxinas y estrés oxidativo (Cao et al, 2006). Además, una proporción elevada (56\%) de los genes regulados por GAs según Owaga et al (2003), fueron también identificados por Cao et al (2006) (Tabla Suplementaria II). Finalmente, Zentella et al (2007) identificaron 67 genes de respuesta temprana a GAs en tejidos 
vegetativos (tallos) de plántulas del mutante ga1-3 de Arabidopsis de 8 días de edad en presencia o ausencia de un tratamiento de GAs (1h con $2 \mu \mathrm{M} \mathrm{GA}_{4}$ ). En este caso, el número de genes de respuesta de GAs identificado fue mucho menor que en los trabajos anteriores (Ogawa et al, 2003; Cao et al, 2006). Además, los cambios de expresión observados tras $1 \mathrm{~h}$ de tratamiento con GAs son muy sutiles, inferiores a 2 veces (Zentella et al, 2007). Estas diferencias pueden deberse a las condiciones experimentales o a los tejidos estudiados, semillas en germinación (Ogawa et al, 2003; Cao et al, 2006) y flores en desarrollo (Cao et al, 2006) frente a tallos vegetativos (Zentella et al, 2007). 



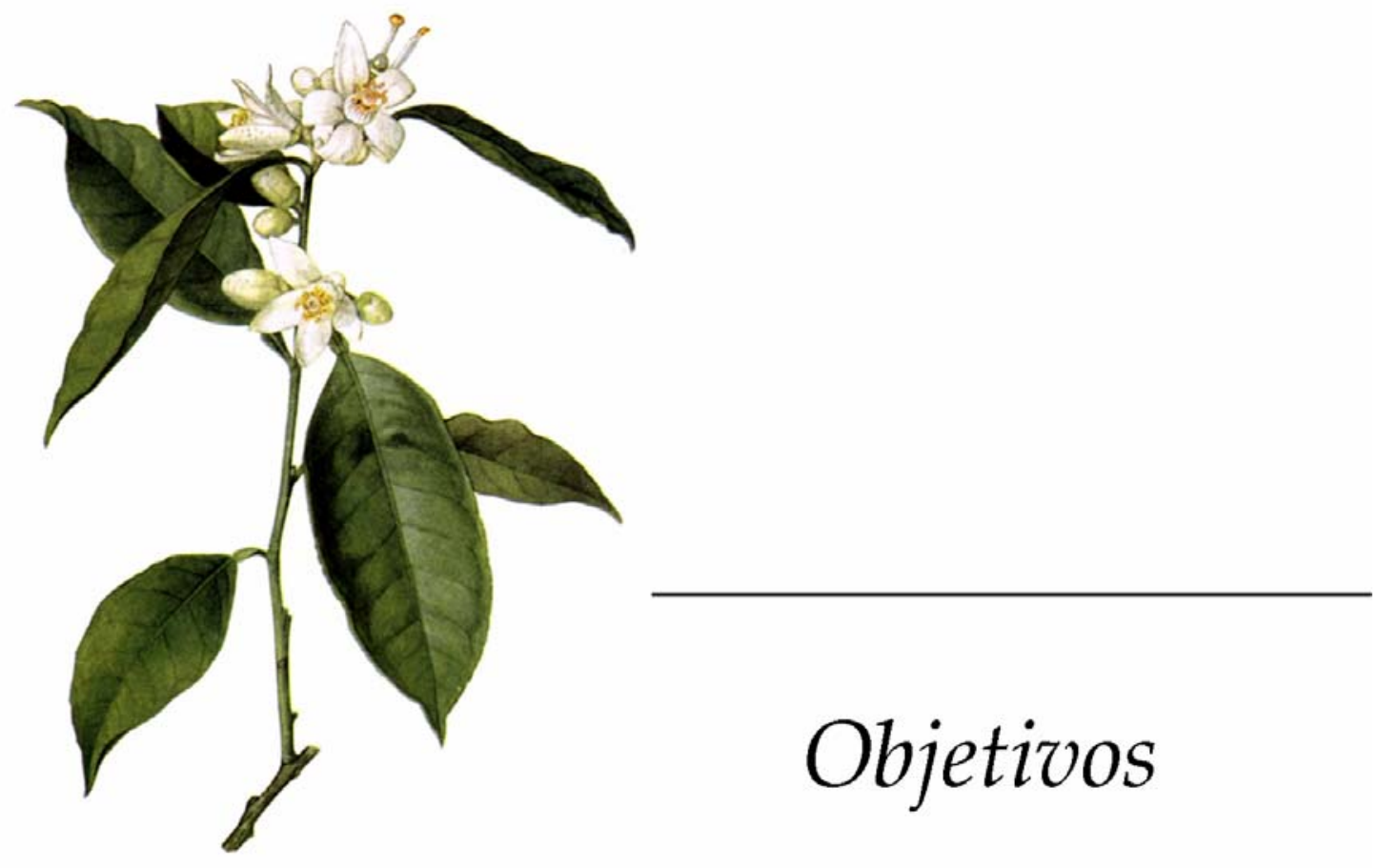





\section{OBJETIVOS}

El trabajo presentado en esta memoria de Tesis Doctoral se ha centrado en el desarrollo de nuevas herramientas de genómica funcional que, por un lado, permitan profundizar en la comprensión de los mecanismos moleculares subyacentes a la biología de los cítricos, en particular de los relacionados con el desarrollo vegetativo, y que, por otro lado, constituyan un sólido punto de apoyo en el diseño de futuros programas de mejora para la obtención de nuevas variedades de cítricos. Los objetivos específicos planteados en este trabajo son:

I) Identificar genes implicados en el desarrollo vegetativo en cítricos mediante la generación y el análisis funcional de una colección de ESTs de tejidos vegetativos.

II) Identificar genes relacionados con el metabolismo de isoprenoides y flavonoides en cítricos mediante el análisis funcional de la colección de ESTs generada por el Proyecto de Genómica Funcional de Cítricos (CFGP).

III) Caracterizar la micromatriz de cDNA generada por el CFGP con el fin de valorar la fiabilidad de los datos obtenidos.

IV) Elaborar mapas de expresión génica de los tejidos reproductivos y vegetativos mediante el análisis de micromatrices de cDNA con el fin de profundizar en la comprensión de las funciones de cada uno de los tejidos estudiados.

V) Estudiar la regulación del desarrollo vegetativo mediada por GAs, por un lado, mediante el análisis del transcriptoma de plantas transgénicas del patrón de cítricos citrange Carrizo que contienen niveles elevados de GAs y, por otro, mediante el análisis de la expresión génica de brotes vegetativos de citrange Carrizo incubados con ácido giberélico. 



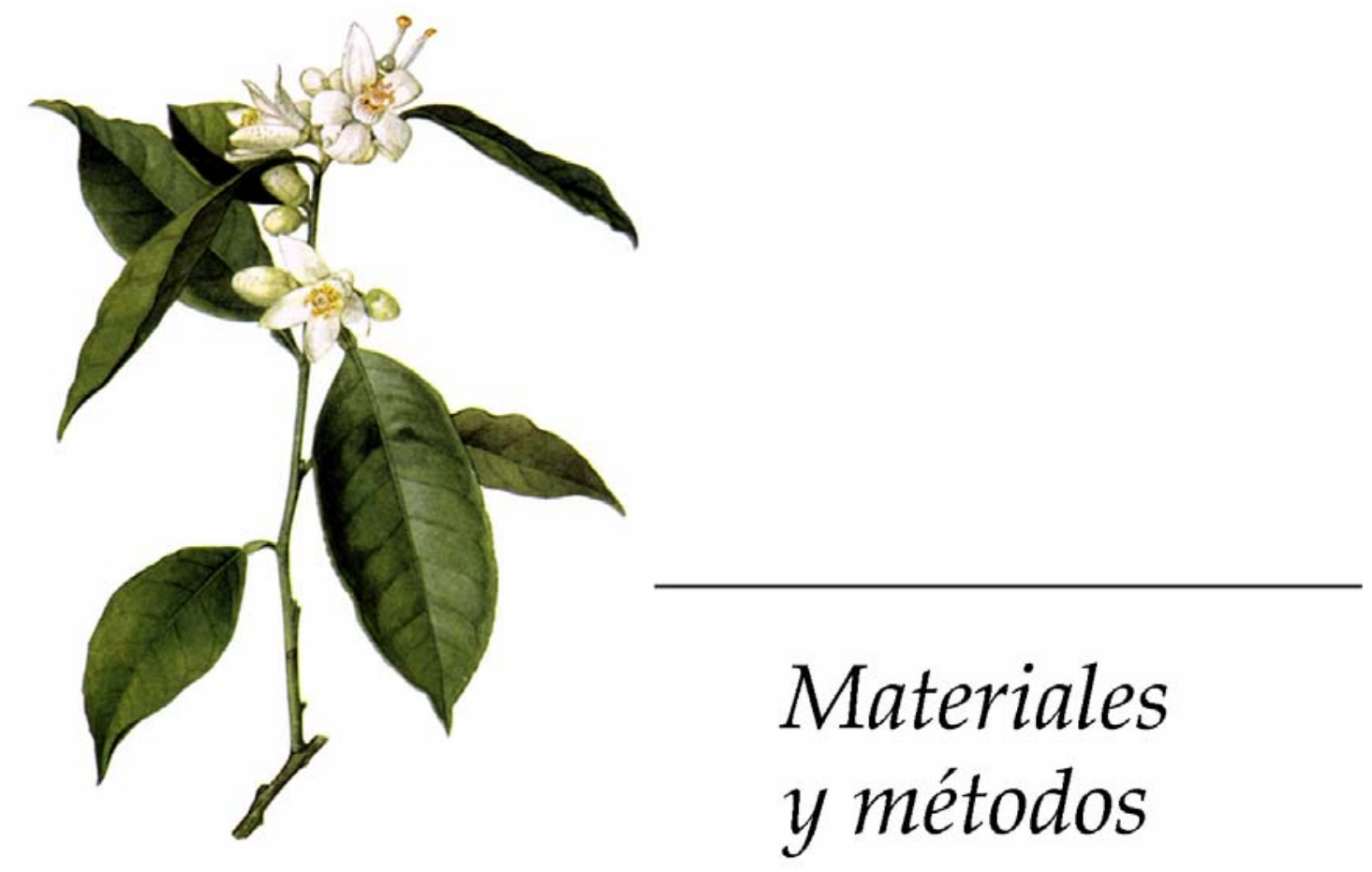





\section{Material vegetal y tratamientos hormonales}

\subsection{Material de campo}

La genoteca de cDNA de tejidos vegetativos se realizó a partir de hojas y entrenudos de brotes en desarrollo de la brotación de otoño procedentes de tres árboles adultos de la variedad de mandarina Clemenules (Citrus clementina Hort. ex Tan.) injertados sobre el patrón mandarino Cleopatra (Citrus reshni Hort. ex Tan.), del Banco de Germoplasma de cítricos del Instituto Valenciano de Investigaciones Agrarias (IVIA), localizado en Moncada (Valencia). Los árboles presentaban buen vigor y estaban libres de plagas. Los tratamientos hormonales consistieron en la pulverización directa, sobre brotes jóvenes de estos árboles de soluciones de $\mathrm{GA}_{3}$ (50 ppm) y de placlobutrazol (500 ppm). El RNA procedente de brotes jóvenes tratados con $\mathrm{GA}_{3}$, brotes jóvenes tratados con paclobutrazol y hojas y entrenudos procedentes de brotes jóvenes sin tratar se utilizó para construir una genoteca de cDNA.

En los análisis de expresión génica diferencial entre distintos tejidos de cítricos, los tejidos reproductivos estudiados se obtuvieron de estos mismos árboles. Se recogieron flores y frutos en los estadios fenológicos, según la escala BBCH (Agustí et al, 1995), de botón blanco (56), bola hueca (59) y antesis (61) y frutos con estilo (69) y sin estilo (71), respectivamente. El muestreo se realizó al azar en diferentes zonas de los tres árboles formando tres lotes o réplicas biológicas.

Para el análisis del efecto de GAs sobre el transcriptoma de cítricos, se utilizaron entrenudos en desarrollo procedentes de árboles transgénicos de citrange Carrizo (un híbrido de Citrus sinensis L. Osb. var. Washington Navel x Poncirus trifoliata L. Raf) que sobre-expresan el gen CcGA20ox1, tanto en sentido como en antisentido (Fagoaga et al, 2007). Las líneas seleccionadas para este trabajo fueron la línea sentido $S 23$ y la línea antisentido A4, que muestran una expresión elevada del transgén CcGA20ox1 y niveles modificados de GAs en tejidos vegetativos (Fagoaga et al, 2007). Estos árboles fueron producidos a partir de estaquillas enraizadas y cultivados en condiciones estándar en una parcela experimental del IVIA. Como controles se utilizaron árboles generados por el mismo procedimiento pero transformados únicamente con el vector vacío. La caracterización del transcriptoma de estas plantas se realizó utilizando entrenudos procedentes de brotes vegetativos en desarrollo de la brotación de otoño.

En todos los casos, incluyendo el material de invernadero, las muestras se congelaron en $\mathrm{N}_{2}$ líquido y se conservaron a $-80^{\circ} \mathrm{C}$ hasta la extracción de RNA. 


\subsection{Material de invernadero}

En la caracterización técnica de la micromatriz de cDNA de cítricos del CFGP se utilizaron hojas en desarrollo procedentes de plantas de Citrus clementina de 2 años de edad cultivadas en los invernaderos del Instituto de Biología Molecular y Celular de Plantas (IBMCP), localizado en la Universidad Politécnica de Valencia. En los experimentos de análisis de expresión génica diferencial entre distintos tejidos de cítricos se utilizaron las cuatro últimas hojas apicales de brotes vegetativos. Se definieron 5 estadios de desarrollo del brote en función del tamaño de estas últimas hojas: 1) estadio 1 , brotes con hojas de 1-2 cm, 2) estadio 2, brotes con hojas de 2-3 cm, 3) estadio 3 , brotes con hojas de $3-4 \mathrm{~cm}, 4$ ) estadio 4 , brotes con hojas de 4-6 cm y 5) estadio 5 , brotes con hojas de $6-8 \mathrm{~cm}$.

El efecto de GAs a tiempos cortos se estudió utilizando brotes jóvenes de unos $10 \mathrm{~cm}$ de longitud, con 5-6 hojas en desarrollo, de plantas de citrange Carrizo procedentes de semilla de unos 3 meses de edad. Los brotes se cortaron y se incubaron durante $24 \mathrm{~h}$ en viales con $40 \mathrm{ml}$ de medio de Murashige y Skoog con o sin $10 \mu \mathrm{M} \mathrm{GA}_{3}$. La incubación de los explantes se realizó a $24^{\circ} \mathrm{C}$ en condiciones de fotoperiodo de $16 \mathrm{~h}$ de luz y $8 \mathrm{~h}$ de oscuridad. Se realizaron cuatro réplicas biológicas, con 5 brotes por réplica, para cada uno de los tratamientos: tiempo 0 y $24 \mathrm{~h}$ sin y con $\mathrm{GA}_{3}$. El análisis transcriptómico se realizó utilizando los entrenudos procedentes de los explantes de cada uno de los tratamientos descritos.

\section{Extracción de RNA total y RNA poli $\left(A^{+}\right)$de plantas}

La extracción de RNA se llevó a cabo utilizando el protocolo general que se describe más adelante. En los experimentos con micromatrices, el RNA obtenido se purificó tal como se describe en el apartado 2.1.1 puesto que este paso adicional mejoró notablemente la eficiencia del marcaje de las muestras de RNA. En todos los casos, la pureza del RNA obtenido se evaluó mediante medidas de absorbancia a 230 , 260 y 280 nm obtenidas utilizando el espectrofotómetro NanoDrop ND-100 (NanoDrop Technologies). La relación 260:280 es indicativa de posible contaminación por proteínas mientras que el cociente 260:230 indica el grado de contaminación por carbohidratos y otros metabolitos. En general, se trabajó con RNA con valores superiores a 1.9 para ambos cocientes. 


\subsection{Protocolo general de extracción de RNA total}

La extracción de RNA total de cítricos se realizó siguiendo el protocolo descrito por Malmberg et al (1985). Unos $500 \mathrm{mg}$ de material vegetal triturado en mortero con $\mathrm{N}_{2}$ líquido se homogeneizaron en $0.5 \mathrm{ml}$ de tampón TCES $(0.2 \mathrm{M}$ Tris- $\mathrm{HCl} \mathrm{pH} 8,0.2 \mathrm{M}$ $\mathrm{NaCl}, 50 \mathrm{mM}$ EDTA, $2 \% \mathrm{SDS}$ ), $0.5 \mathrm{ml}$ de fenol ácido (Prolabo) y $5 \mu \mathrm{ll}$ $\beta$-mercaptoetanol y se incubaron $5 \mathrm{~min}$ a $50^{\circ} \mathrm{C}$. El extracto se centrifugó $10 \mathrm{~min}$ a 2,000 rpm y el sobrenadante se transfirió a un tubo nuevo al que se añadió $0.8 \mathrm{ml}$ de cloroformo:alcohol isoamílico (24:1), agitando con vórtex durante $2 \mathrm{~min}$. La fase acuosa obtenida tras centrifugar $10 \mathrm{~min}$ a 2,000 rpm se transfirió a un microtubo que se volvió a centrifugar 15 min a 13,000 rpm. El sobrenadante se precipitó con LiCl $3 \mathrm{M}$ a $4^{\circ} \mathrm{C}$ durante toda la noche y se recogió por centrifugación durante 15 min a $13,000 \mathrm{rpm}$. El precipitado se lavó tres veces consecutivas con $1 \mathrm{ml}$ de etanol al $70 \%$, se secó en vacío durante 5 min y se resuspendió en $40 \mu \mathrm{l}$ de agua tratada con dietil pirocarbonato (DEPC). El rendimiento obtenido con este procedimiento fue de 200-300 $\mu \mathrm{g}$ de RNA total por 500 mg de peso fresco.

\subsubsection{Purificación adicional del RNA para los experimentos con micromatrices}

El RNA total obtenido con el método descrito se purificó, adicionalmente, utilizando el sistema RNeasy Mini Kit (Qiagen), siguiendo las instrucciones del fabricante. Para ello, $100 \mu \mathrm{g}$ de RNA total (en un volumen de $100 \mu \mathrm{l}$ ) se mezclaron con $350 \mu \mathrm{l}$ de tampón de lisis (contiene tiocianato de guanidinio y $\beta$-mercaptoetanol) y con $250 \mu \mathrm{l}$ de etanol (100\%). La muestra se transfirió a una columna RNeasy, donde el RNA se une a una membrana de gel de sílice. La columna se lavó dos veces con un tampón que contiene etanol, se secó por centrifugación a 13,000 rpm durante 1 min y el RNA se eluyó en $30 \mu \mathrm{l}$ de agua libre de RNasa (Qiagen). El rendimiento obtenido con el procedimiento descrito fue de 75-90 $\mu$ g de RNA purificado por $100 \mu \mathrm{g}$ de RNA total.

\subsubsection{Purificación adicional del RNA para los experimentos de RT-PCR}

En los experimentos de RT-PCR, el RNA total obtenido mediante el método general se trató con DNasa I libre de RNasa (Qiagen) para eliminar la contaminación de las muestras con DNA genómico. El procedimiento seguido fue similar al descrito en el apartado 2.1.1 pero la muestra de RNA, fijada a la membrana de la columna 
RNeasy, se digirió con $3 \mathrm{U}$ de DNasa I, siguiendo las instrucciones del fabricante, antes de proceder al lavado de la columna y a la elución del RNA.

\subsection{Extracción de poli $\left(A^{+}\right)$RNA}

El poli $\left(\mathrm{A}^{+}\right)$RNA se extrajo con el sistema QuickPrep micro mRNA Purification Kit (Amersham Biosciences) a partir de $250 \mu \mathrm{g}$ de RNA total obtenidos según el protocolo descrito por Malberg et al (1985). A la solución acuosa de RNA total se añadió $400 \mu \mathrm{l}$ del tampón de extracción (contiene tiocianato de guanidinio y $\mathrm{N}$-lauroil sarcosinato) y $800 \mu \mathrm{l}$ de tampón TE (10 mM Tris- $\mathrm{HCl}$ pH 7.5, $1 \mathrm{mM}$ EDTA) y la mezcla se centrifugó 1 min a 13,000 rpm. La fase superior se transfirió al lecho de oligo(dT)celulosa obtenido previamente por centrifugación y se resuspendió. Dicha suspensión se centrifugó $10 \mathrm{~s}$ a 13,000 rpm y se lavó cinco veces con $1 \mathrm{ml}$ de tampón TEN (10 mM Tris- $\mathrm{HCl} \mathrm{pH} 7.5,1 \mathrm{mM}$ EDTA, $0.5 \mathrm{M} \mathrm{NaCl}$ ), dos veces más con $1 \mathrm{ml}$ de tampón TEN 0.1X (10 mM Tris- $\mathrm{HCl} \mathrm{pH}$ 7.5, $1 \mathrm{mM}$ EDTA, $0.1 \mathrm{M} \mathrm{NaCl})$, se resuspendió en $0.3 \mathrm{ml}$ de este último tampón y se transfirió a una micro-columna de polipropileno. La columna se centrifugó $5 \mathrm{~s}$ a 13,000 rpm y se lavó tres veces con $0.5 \mathrm{ml}$ de tampón TEN 0.1X. Finalmente, el poli $\left(\mathrm{A}^{+}\right) \mathrm{RNA}$ se eluyó dos veces con $0.2 \mathrm{ml}$ de tampón TE a $65^{\circ} \mathrm{C}$. Este RNA poli $\left(\mathrm{A}^{+}\right)$se precipitó con 0.1 volúmenes de acetato potásico $2.5 \mathrm{M}$ $\mathrm{pH} 5,2.5$ volúmenes de etanol y $10 \mu \mathrm{l}$ de glucógeno $(5 \mathrm{mg} / \mathrm{ml})$ durante toda la noche a $4^{\circ} \mathrm{C}$. El poli $\left(\mathrm{A}^{+}\right)$se recogió por centrifugación a $13,000 \mathrm{rpm}$ durante $10 \mathrm{~min}$ a $4^{\circ} \mathrm{C}$, se lavó con etanol al $70 \%$ y se resuspendió en $20 \mu \mathrm{l}$ de agua libre de RNasa (Amersham Biosciences). El rendimiento obtenido en las extracciones de poli $\left(A^{+}\right)$RNA fue alrededor del $2 \%$.

\section{Construcción y manipulación de una genoteca de cDNA}

\subsection{Genoteca primaria}

La genoteca direccional de cDNA de tejidos vegetativos en desarrollo se construyó a partir de una mezcla a partes iguales de RNA procedente de brotes jóvenes tratados con $\mathrm{GA}_{3}$, brotes jóvenes tratados con paclobutrazol y hojas y entrenudos procedentes de brotes jóvenes sin tratar. Para ello se utilizó el sistema IZAP-cDNA Synthesis Kit and Gigapack III Gold Cloning Kit (Stratagene), siguiendo las instrucciones del fabricante (http://www.stratagene.com/manuals/200401.pdf). La primera cadena de cDNA se sintetizó a partir de $5 \mu \mathrm{g}$ de RNA poli $\left(\mathrm{A}^{+}\right)$, tratado 5 min a $65^{\circ} \mathrm{C}$ para relajar la estructura secundaria, utilizando transcriptasa reversa $(50 \mathrm{U} / \mu \mathrm{l})$, 
oligo (dT) que contiene un sitio de restricción Xhol como cebador y en presencia de 5metil-dCTP, de modo que se obtuvo un cDNA hemimetilado. En paralelo se realizó una síntesis control que además incorpora $\left[\alpha^{32} \mathrm{P}\right]$ dATP $(800 \mathrm{Ci} / \mathrm{mmol})$. Antes de la síntesis de la segunda cadena de cDNA, el cDNA se incubó con RNasa $H(1.5 \mathrm{U} / \mu \mathrm{l})$, que degrada la cadena de RNA molde utilizado para la síntesis de la primera cadena. La segunda cadena de cDNA se sintetizó con DNA polimerasa I (9 $\mathrm{U} / \mu \mathrm{l})$, en presencia de $\left[\alpha^{32} \mathrm{P}\right]$ dATP $(800 \mathrm{Ci} / \mathrm{mmol})$ para comprobar la calidad del cDNA obtenido en un gel de agarosa alcalino. Tras formar extremos romos en el cDNA de doble cadena mediante Pfu DNA polimerasa $(2.5 \mathrm{U} / \mu \mathrm{l})$, se procedió a la ligación, mediante T4 DNA ligasa (4 $\mathrm{U} / \mu \mathrm{l})$, de unos adaptadores que incluyen un extremo cohesivo EcoRI y a la posterior fosforilación de los mismos mediante T4 polinucleótico kinasa (10 U/ $/ \mathrm{ll}$ ). El cDNA modificado con los adaptadores EcoRI se digirió con la enzima de restricción Xhol (40 $\mathrm{U} / \mu \mathrm{l}$ ) de modo que se obtuvo un cDNA con un sitio EcoRI en el extremo 5' y un sitio Xhol en el extremo 3'. Este cDNA se fraccionó por tamaño con una columna Sephacryl S-500 (Life Technologies) y se seleccionaron las fracciones correspondientes a cDNAs de longitud mayor a 500 pb. El cDNA (100 ng) se ligó de forma direccional con el vector Uni-ZAP XR y los productos de la ligación se empaquetaron utilizando el extracto de empaquetamiento Gigapack III Gold (Stratagene). El número de fagos existentes en la genoteca primaria se calculó mediante la titulación de la misma. Para ello, una colonia de la cepa XL1-Blue MRF' se creció a $37^{\circ} \mathrm{C}$ en medio líquido $\mathrm{YT} 2 \mathrm{X}$ (16 $\mathrm{g} / \mathrm{l}$ triptona, $5 \mathrm{~g} / \mathrm{l} \mathrm{NaCl}, 10 \mathrm{~g} / \mathrm{l}$ extracto de levadura) suplementado con $0.2 \%$ maltosa y $10 \mathrm{mM} \mathrm{MgSO}_{4}$ hasta una $\mathrm{OD}_{600}$ de 0.5. Las células XL1-Blue MRF' (200 $\left.\mu \mathrm{l}\right)$ se incubaron $15 \mathrm{~min}$ a $37^{\circ} \mathrm{C}$ con varias diluciones de la genoteca primaria y se crecieron a $37^{\circ} \mathrm{C}$ durante toda la noche en placas de agar YT $2 X(16 \mathrm{~g} / \mathrm{l}$ triptona, $5 \mathrm{~g} / \mathrm{l}$ $\mathrm{NaCl}, 10 \mathrm{~g} / \mathrm{l}$ extracto de levadura, $15 \mathrm{~g} / \mathrm{l}$ agar bacteriológico) suplementadas con 10 $\mathrm{mM} \mathrm{MgSO}_{4}$. El número de calvas o pfu (plaque forming units) obtenidas con las distintas diluciones permitió calcular la titulación de la genoteca.

\subsection{Genoteca amplificada}

La amplificación de la genoteca se realizó en 20 alícuotas de unos $5 \times 10^{4}$ pfu aproximadamente con $600 \mu \mathrm{l}$ de células XL1-Blue MRF' (Stratagene). Las células infectadas se sembraron en placas de $150 \mathrm{~mm}$ con agar NZY $(5 \mathrm{~g} / \mathrm{l} \mathrm{NaCl}, 2 \mathrm{~g} / \mathrm{l} \mathrm{MgSO}$, $5 \mathrm{~g} / \mathrm{l}$ extracto de levadura, $10 \mathrm{~g} / \mathrm{l}$ hidrolizado de caseína, $15 \mathrm{~g} / \mathrm{l}$ agar) y se incubaron a $37^{\circ} \mathrm{C}$ hasta que comenzaron a diferenciarse las calvas. Se añadió $8 \mathrm{ml}$ de solución SM $\left(5.8 \mathrm{~g} / \mathrm{l} \mathrm{NaCl}, 2 \mathrm{~g} / \mathrm{MgSO}_{4}, 50 \mathrm{ml}\right.$ Tris- $\mathrm{HCl} 1 \mathrm{M}, 5 \mathrm{ml}$ gelatina 2\%) a cada placa y se incubó con agitación suave a $4^{\circ} \mathrm{C}$ durante toda la noche para facilitar la difusión de los 
fagos. La suspensión de fagos se recogió, se añadió cloroformo $5 \%$ y se centrifugó para eliminar los restos celulares. El sobrenadante se recogió y se añadió cloroformo hasta una concentración final de $0.3 \%(\mathrm{v} / \mathrm{v})$. La genoteca amplificada, denominada Veg1, se almacenó a $-80^{\circ} \mathrm{C}$ en alícuotas con dimetil sulfóxido (DMSO) al $7 \%(\mathrm{v} / \mathrm{v})$ y se tituló siguiendo el mismo procedimiento descrito para la genoteca primaria.

\subsection{Escisión masiva}

El vector Uni-ZAP XR permite la escisión in vivo del fagémido pBluescript de modo que los insertos pueden ser caracterizados en un sistema de plásmidos. La escisión masiva de la genoteca amplificada se realizó a partir de $10^{7}$ pfu de fagos, $10^{8}$ pfu de células XL1-Blue MRF' y $10^{9}$ pfu de fago ExAssist (Stratagene). Las células coinfectadas se incubaron en medio LB (10 g/l triptona, $10 \mathrm{~g} / \mathrm{l} \mathrm{NaCl}, 5 \mathrm{~g} / \mathrm{l}$ extracto de levadura) a $37^{\circ} \mathrm{C}$ durante $2-3 \mathrm{~h}$ con agitación, se lisaron por incubación a $65-70^{\circ} \mathrm{C}$ durante $20 \mathrm{~min}$, se centrifugaron y se recogió el sobrenadante que contiene los fagémidos con los clones en forma de DNA de cadena simple. La infección de $200 \mu \mathrm{l}$ de células SOLR $\left(\mathrm{OD}_{600}\right.$ de 1$)$ con $1 \mu \mathrm{l}$ de este sobrenadante se produjo por incubación a $37^{\circ} \mathrm{C}$ durante 15 min y permitió obtener DNA de doble cadena en forma de plásmidos. Las células SOLR infectadas con los fagémidos (10 $\mu \mathrm{l})$ se sembraron en placas de agar LB (10 g/l triptona, $10 \mathrm{~g} / \mathrm{l} \mathrm{NaCl}, 5 \mathrm{~g} / \mathrm{l}$ extracto de levadura, $20 \mathrm{~g} / \mathrm{l}$ agar bacteriológico) con ampicilina $(50 \mu \mathrm{g} / \mathrm{ml})$ y se incubaron a $37^{\circ} \mathrm{C}$ durante toda la noche para obtener colonias bacterianas aisladas.

\section{Generación de una colección de ESTs}

\subsection{Obtención de DNA plasmídico y secuenciación}

\subsubsection{Cultivos bacterianos}

Las colonias bacterianas aisladas generadas por escisión masiva de la genoteca amplificada se seleccionaron al azar y se cultivaron en placas de 96 pocillos (Eppendorf) con $1.5 \mathrm{ml}$ de medio LB 2X (20 g/l triptona, $10 \mathrm{~g} / \mathrm{l}$ extracto de levadura, $10 \mathrm{~g} / \mathrm{l} \mathrm{NaCl})$ y ampicilina $(50 \mathrm{mg} / \mathrm{l})$. Los cultivos en placa se incubaron a $37^{\circ} \mathrm{C}$ con agitación $(300 \mathrm{rpm})$ durante $20 \mathrm{~h}$. Una parte del cultivo $(150 \mu \mathrm{l})$ se transfirió a una nueva placa de 96 pocillos (Axygen) a la que se añadió glicerol hasta una concentración final de 15\%. Estas placas, que suponen un duplicado de cada clon, se sellaron con láminas estériles de aluminio y se almacenaron a $-80^{\circ} \mathrm{C}$. 


\subsubsection{Obtención de DNA plasmídico}

En este trabajo se han utilizado dos métodos para la obtención de DNA plasmídico en placas de 96 pocillos: el sistema PerfectPrep (Eppendorf) y el método Montage (Millipore).

\section{Sistema PerfectPrep (Eppendorf)}

EI DNA plasmídico se obtuvo por lisis alcalina mediante el sistema PerfectPrep Plasmid 96 Vac Direct Bind (Eppendorf) siguiendo las instrucciones del fabricante. Las placas con el cultivo bacteriano se centrifugaron a $3000 \mathrm{rpm}$ durante $5 \mathrm{~min}$, se eliminó el sobrenadante y los sedimentos bacterianos se resuspendieron completamente en la solución 1 que contiene RNasa A $(150 \mu \mathrm{l})$ utilizando el vórtex. A continuación se añadió la solución 2 de lisis alcalina $(150 \mu \mathrm{l})$, la solución 3 de neutralización (150 $\mu \mathrm{l})$ y este lisado bacteriano se transfirió a una nueva placa que contiene un filtro. Se aplicó vacío durante 5 min de modo que los restos celulares quedaron retenidos en el filtro y los lisados pasaron a la placa inferior, que contiene una membrana. En esta segunda placa se añadió $300 \mu \mathrm{l}$ de la solución 4 que contiene guanidinio, se aplicó vacío durante 2 min, se añadió $400 \mu \mathrm{l}$ de tampón salino y se aplicó vacío durante 5 min más. EI DNA plasmídico retenido en la membrana de esta segunda placa se eluyó en $30 \mu \mathrm{l}$ de agua estéril por aplicación de vacío durante 5 min.

\section{Método Montage (Millipore)}

El método de purificación de DNA plasmídico Montage (Millipore) consiste en una versión modificada del método de lisis alcalina. El procedimiento es muy similar al descrito en el apartado anterior salvo que, en este caso, todos los pasos se realizaron de forma automatizada utilizando el dispensador de líquidos MultiProbe II (Packard).

\subsubsection{Secuenciación}

La cantidad de DNA plasmídico obtenido se estimó mediante electroforesis en geles de agarosa 1\% y TAE $1 \mathrm{X}$ de una alícuota del mismo, obteniendo una

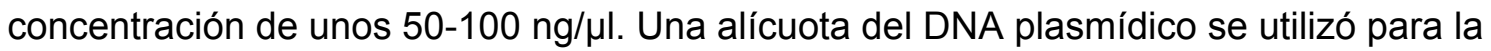
secuenciación de los clones desde el extremo 5', que se llevó a cabo en el Servicio de Secuenciación del IBMCP. La secuenciación se basó en el uso de dideoxinucleótidos marcados con compuestos fluorescentes, utilizando el sistema ABI PRISM Big Dye 
Terminator Cycle Sequencing Kit (Applied Biosystems). Las reacciones de secuenciación se realizaron en un termociclador ABI GeneAmp PCR System 9700 (Applied Biosystems) y los productos marcados se resolvieron y analizaron en un secuenciador capilar ABI 3100 (Applied Biosystems). Finalmente, otra alícuota del DNA plasmídico se utilizó para la construcción de la micromatriz de cDNA del CFGP, tal como se describe en el apartado 5 .

\subsection{Pre-procesado y ensamblaje de ESTs}

El pre-procesado y ensamblaje de las secuencias obtenidas se realizó con EST2uni (Forment et al, 2008; http://bioinf.comav.upv.es/est2uni), herramienta bioinformática desarrollada en el CFGP. El pre-procesado de las secuencias consta de los siguientes pasos: 1) lectura de la secuencia nucleotídica definida en cada cromatograma y asignación de un valor de calidad a cada base, mediante el programa Phred (Ewing et al, 1998); 2) eliminación de las regiones de baja calidad y de las regiones procedentes del vector con el programa Lucy (Chou y Holmes, 2001); 3) enmascaramiento de elementos repetitivos y regiones de baja complejidad con los programas RepeatMasker (http://www.repeatmasker.org) y SeqClean (http://compbio. dfci.harvard.edu/tgi/software), respectivamente; y 4) detección y eliminación de secuencias contaminantes con el programa SeqClean utilizando la base de datos UniVec del NCBI (http://www.ncbi.nlm.nih.gov/VecScreen/UniVec.html). Tras el pre-procesado de las secuencias, todas aquéllas que no superaron una longitud de 100 bases no se incluyeron en los análisis posteriores.

Las secuencias de alta calidad, obtenidas mediante el procedimiento de pre-procesado descrito, se agruparon con el doble objetivo de eliminar redundancia y obtener un conjunto de posibles genes únicos. El agrupamiento o ensamblaje de las ESTs de alta calidad se realizó con la herramienta TGICL (Pertea et al, 2003) que, en un primer paso, agrupa las secuencias basándose en la comparación por parejas de todas ellas utilizando el algoritmo Megablast (Zhang et al, 2000) y, en un paso posterior, ensambla cada grupo de secuencias utilizando el algoritmo CAP3 (Huang y Madan, 1999), manteniendo los parámetros que establece el algoritmo por defecto: 1) solapamiento entre dos secuencias $>30 \mathrm{pb}$; 2) identidad de las secuencias en la región solapada $>94 \%$; y 3 ) número de bases que no solapan $<30 \mathrm{pb}$. Tras el agrupamiento, para cada grupo de secuencias o contig (conjunto de secuencias formado por dos o más ESTs), se obtuvo una secuencia consenso. Las ESTs que, según los parámetros anteriores, no forman parte de ningún grupo constituyen los singletons (ESTs que no muestran similitud con ninguna otra secuencia de la 
colección). Así pues, la colección de ESTs generada queda agrupada en un conjunto no redundante de posibles genes únicos (o unigenes) formado tanto por los contigs como por los singletons. La secuencia deducida de aminoácidos de cada unigen se obtuvo utilizando ESTScan (Iseli et al, 1999).

\subsection{Anotación funcional de los unigenes}

\subsubsection{Metodología para la anotación básica de los unigenes: base de datos EST2uni}

La anotación funcional de los unigenes de cítricos se llevó a cabo utilizando la base de datos EST2uni (Forment et al, 2008; http://bioinf.comav.upv.es/est2uni). Esta herramienta realiza búsquedas automáticas con el algoritmo BLAST (Altschul et al, 1997) frente a la base de datos UniRef90 (Wu et al, 2006; http://www.ebi.ac.uk/uniref; UniProtKB versión 8.9; 17 Octubre 2006) y al conjunto completo de proteínas de Arabidopsis obtenido del TAIR (Rhee et al, 2003; http://www.arabidopsis.org; TAIR6 Noviembre 2005), utilizando los parámetros por defecto y un criterio no estricto de $10^{-5}$ para el valor $E$. Los unigenes fueron anotados con la descripción del conjunto de proteínas de UniRef90 más similar o, con la descripción de la proteína de Arabidopsis más similar. Los unigenes se anotaron como 'altamente similares' cuando el primer resultado del BLAST presentaba un valor $E$ menor que $10^{-15}$. Los unigenes cuyo primer resultado del BLAST mostraba un valor $E$ mayor que $10^{-5}$ no se consideraron para la anotación. Adicionalmente, se ha llevado a cabo la anotación funcional de los unigenes de cítricos basada en motivos funcionales utilizando el algoritmo de búsqueda HMMER (Eddy, 1998) frente a la base de datos de familias de proteínas Pfam (http://pfam.janelia.org; Bateman et al, 2004).

\subsubsection{Métodos para la anotación adicional de los unigenes}

La anotación básica de los unigenes realizada con EST2uni, en particular de los unigenes procedentes de la genoteca de tejidos vegetativos y de los unigenes implicados en el metabolismo de isoprenoides y flavonoides, se suplementó con información adicional completando así la anotación existente. Esta anotación adicional se realizó de forma automática cuando fue posible; sin embargo, en algunos casos, exigió una revisión manual de la anotación obtenida con EST2uni. Los métodos que se utilizaron para desarrollar esta anotación adicional se describen a continuación. 


\section{Categorías funcionales}

Los unigenes de cítricos representados en la genoteca de tejidos vegetativos se anotaron según dos modelos de anotación adicionales: la ontología génica (GO; Ashburner et al, 2000) organizada en tres categorías generales ('proceso biológico', 'función molecular' y 'componente celular') y la anotación funcional del MIPS (Munich Information Centre for Protein Sequences; http://mips.gsf.de; MIPS v2.1). La asignación de GO se realizó utilizando el programa FatiGO (Al-Shahrour et al, 2004; http://www.babelomics.org) mientras que la anotación funcional del MIPS se obtuvo mediante la herramienta FunCat (Ruepp et al, 2004). Para ello, se utilizó el código AGI (Arabidopsis Genome Initiative, 2000) correspondiente al gen de Arabidopsis más similar a cada unigen de cítricos.

El programa FatiGO se utilizó, adicionalmente, para llevar a cabo los análisis de enriquecimiento funcional puesto que permite encontrar términos GO significativamente sobre-representados en un conjunto de genes respecto a un grupo de referencia. En este análisis se tuvo en cuenta la corrección por experimentos múltiples, pues de no ser así se produce un aumento en la proporción de falsos positivos, es decir, términos GO identificados como sobre-representados cuando, realmente, no lo están. El método de corrección utilizado fue el de FDR (False Discovery Rate) (Benjamini y Hochberg, 1995).

\section{$\underline{\text { Rutas metabólicas }}$}

Con el objetivo de obtener una anotación más integrada de los unigenes de cítricos, se utilizaron tres bases de datos adicionales: MetaCyc (Krieger et al, 2004; http://metacyc.org), AraCyc (Mueller et al, 2003; http://www.arabidopsis.org/biocyc) y KEGG (Kanehisa et al, 2004; http://genome.ad.jp/kegg). MetaCyc es una base de datos que contiene rutas metabólicas verificadas experimentalmente e información sobre enzimas corregida a partir de la literatura científica. Una ruta metabólica en MetaCyc consiste en el conjunto de reacciones, enzimas y metabolitos que la componen y los genes que codifican dichas enzimas, así como la información sobre su regulación en diferentes especies, desde microorganismos a plantas y humanos. Las rutas de Arabidopsis se exportan a AraCyc, la base de datos del metabolismo de Arabidopsis, de modo que MetaCyc constituye la base de datos de referencia. La base de datos del KEGG (Kyoto Encyclopedia of Genes and Genomes) contiene información sobre redes de interacción molecular como rutas y complejos, sobre genes y proteínas y sobre compuestos y reacciones químicas. La metodología seguida 
en este caso fue partir del código AGI correspondiente al gen de Arabidopsis más similar a cada unigen de cítricos, obtener la ruta metabólica en la que participa, extraer las secuencias de otros genes que forman parte de esa ruta y realizar búsquedas en la base de datos del CFGP, utilizando la herramienta EST2uni, para tratar de localizar otros elementos de cítricos de la misma ruta no anotados previamente.

\section{Localización subcelular}

La determinación de la localización subcelular de una proteína constituye un paso importante hacia la comprensión de su función. Los péptidos que dirigen las proteínas a la ruta secretora (SP), a mitocondria (mTP) o a cloroplastos (cTP) se encuentran en la región $\mathrm{N}$-terminal de la secuencia. La secuencia deducida de aminoácidos de cada unigen de cítricos estudiado se obtuvo mediante la herramienta Translate (http://www.expasy.org/tools/dna.html) del Swiss Institute of Bioinformatics (SIB) y se comprobó que contenía la región N-terminal completa mediante BLASTP frente a la base de datos de proteínas no redundantes GenBank del NCBI (http://www.ncbi.nlm.nih.gov/BLAST/). La predicción de la localización subcelular de diversas proteínas de cítricos se realizó siguiendo la metodología descrita por Emanuelsson et al (2007). La secuencia de aminoácidos deducida de cada unigen de cítricos se analizó con TargetP v1.1 (Emanuelsson et al, 2000; http://www.cbs.dtu.dk/ services/TargetP/) que asigna una posible localización, en plantas, para cloroplasto, mitocondria, ruta secretora y otras, y proporciona un coeficiente de fiabilidad $(R C)$ de la predicción. Cuando TargetP predijo un posible péptido señal de cloroplasto (cTP), la secuencia se analizó con ChloroP v1.1 (Emanuelsson et al, 1999; http://www.cbs. dtu.dk/services/ChloroP/) para obtener un informe detallado de las puntuaciones asignadas a lo largo de la secuencia. El valor límite de la predicción es 0.5 , de modo que puntuaciones superiores a 0.55 se consideran bastante sólidas. Cuando la predicción de TargetP fue 'otra localización' se utilizaron otras herramientas de predicción como PSORT (Nakai y Horton, 1999; http://www.psort.org) y BaCelLo (Pierleoni et al, 2006; http://gpcr.biocomp.unibo.it/bacello).

\subsection{Análisis de expresión génica según la frecuencia de ESTs}

La frecuencia de ESTs procedentes de la genoteca Veg1 se utilizó para detectar genes expresados diferencialmente durante el desarrollo vegetativo. Así, para cada unigen de cítricos representado en la genoteca de tejidos vegetativos se calculó tanto la frecuencia de ESTs procedentes de dicha genoteca como la frecuencia de 
ESTs procedentes del resto de la colección del CFGP. La identificación de unigenes expresados diferencialmente en Veg1 se realizó con el programa IDEG6 (Romualdi et al, 2003), utilizando el test estadístico de Audic y Claverie (1997) y la corrección por experimentos múltiples de Bonferroni.

\section{Construcción de la micromatriz de cDNA de cítricos CIT1}

Los análisis de expresión génica se realizaron utilizando la micromatriz de cDNA de cítricos, construida por el Laboratorio de Genómica del CFGP, que contiene 12,672 clones que corresponden a 6,875 posibles unigenes (Forment et al, 2005). Los 12,672 clones contenidos en la micromatriz, que llamaremos CIT1, proceden de 18 genotecas de cDNA (Tabla 1).

\begin{tabular}{|c|c|c|c|}
\hline Genoteca & $\mathrm{N}^{\circ}$ clones $(\%)$ & Especie & Tejido/ estado de desarrollo/ tratamientos \\
\hline Veg1 & $1,152(9.1)$ & C.clementina & $\begin{array}{l}\text { Hojas, entrenudos y brotes apicales: } \\
\text { aplicaciones foliares de } \mathrm{GA}_{3} \text { y paclobutrazol }\end{array}$ \\
\hline IF1 & $1,920(15.2)$ & C. clementina & $\begin{array}{l}\text { Flores en distintos estadios de desarrollo, desde } \\
\text { yemas florales hasta flores en antesis }\end{array}$ \\
\hline OF1 & $192(1.5)$ & C. clementina & $\begin{array}{l}\text { Ovarios senescentes y frutos de } 5 \text { semanas } \\
\text { tratados con } \mathrm{GA}_{3}\end{array}$ \\
\hline OF2 & $1,344(10.6)$ & C. clementina & $\begin{array}{l}\text { Ovarios de yemas florales a frutos de } 1 \text { y } 3 \\
\text { semanas tratados con } \mathrm{GA}_{3}\end{array}$ \\
\hline AbsAOv1 & $128(1.0)$ & C. clementina & $\begin{array}{l}\text { Zona de abscisión A de ovarios en desarrollo } \\
\text { tratados con etileno }\end{array}$ \\
\hline CTVLeafMc1 & $1,248(9.8)$ & C. macrophylla & $\begin{array}{l}\text { Hojas infectadas con el Virus de la Tristeza } \\
\text { de los Cítricos }\end{array}$ \\
\hline DroRLeaf1 & $177(1.4)$ & C. clementina & $\begin{array}{l}\text { Hojas de plantas rehidratadas tras } 24 \mathrm{~h} \text { de } \\
\text { estrés hídrico }\end{array}$ \\
\hline Drought1 & $672(5.3)$ & C. clementina & $\begin{array}{l}\text { Hojas de plantas tras } 5,10,24 \text { h de estrés } \\
\text { hídrico }\end{array}$ \\
\hline Drought2 & $864(6.8)$ & C. reshni & $\begin{array}{l}\text { Raíces de plantas tras } 5,10,24 \text { h de estrés } \\
\text { hídrico }\end{array}$ \\
\hline FlavFr1 & $1,344(10.6)$ & C. clementina & $\begin{array}{l}\text { Flavedo de frutos maduros almacenados } \\
\text { a } 2^{\circ} \mathrm{C} \text { durante } 7 \text { y } 24 \text { días }\end{array}$ \\
\hline FlavRip1 & $215(1.7)$ & C. clementina & Flavedo de frutos en desarrollo \\
\hline FlavSen1 & $288(2.3)$ & C. clementina & Flavedo de frutos senescentes \\
\hline LongSaltL1 & $207(1.6)$ & C. sinensis & \\
\hline NTLeaf1 & $384(3.0)$ & C. clementina & $\begin{array}{l}\text { Hojas de plantas cultivadas en condiciones } \\
\text { estándar }\end{array}$ \\
\hline PhyRootSr1 & $960(7.6)$ & C. aurantium & Raíces infectadas con Phytophthora citrophtora \\
\hline PhyRootSw1 & $864(6.8)$ & C. sinensis & Raíces infectadas con Phytophthora citrophtora \\
\hline Roots1 & $137(1.1)$ & citrange Carrizo & $\begin{array}{l}\text { Raíces de plántulas cultivadas } 1-4 \text { días } \\
\text { con paclobutrazol o auxinas }\end{array}$ \\
\hline SaltLeaf1 & $576(4.5)$ & C. clementina & $\begin{array}{l}\text { Hojas de plantas tratadas con } 150 \mathrm{mM} \mathrm{NaCl} \\
\text { durante } 6,24 \text { h y } 7 \text { días }\end{array}$ \\
\hline
\end{tabular}


La amplificación por PCR de los 12,672 clones para la posterior impresión de los mismos fue realizada por el Laboratorio de Genómica del IBMCP. Las reacciones de PCR se realizaron a partir de $4 \mathrm{ng}$ de DNA plasmídico utilizando $1.5 \mathrm{U}$ de Taq polimerasa, $200 \mu \mathrm{M}$ dNTPs, $400 \mathrm{nM}$ de cebador T7 modificado (5'-CGACTCACTATA GGGCGAATTGG-3') y 400 nM de cebador T3 modificado (5'-GGAAACAGCTATGAC CATGATTAC-3'), en un volumen final de $100 \mu \mathrm{l}$. Las reacciones de PCR se realizaron, en placas de 96 pocillos, a $94^{\circ} \mathrm{C}$ durante $3 \mathrm{~min}$, seguido de 5 ciclos de amplificación $\left(94^{\circ} \mathrm{C}\right.$ durante $30 \mathrm{~s}, 66^{\circ} \mathrm{C}$ durante $30 \mathrm{~s}, 72^{\circ} \mathrm{C}$ durante $\left.2 \mathrm{~min}\right), 30$ ciclos más $\left(94^{\circ} \mathrm{C}\right.$ durante $30 \mathrm{~s}, 60^{\circ} \mathrm{C}$ durante $30 \mathrm{~s}, 72^{\circ} \mathrm{C}$ durante $2 \mathrm{~min}$ ) e incubadas finalmente a $72^{\circ} \mathrm{C}$ durante $10 \mathrm{~min}$. Una alícuota de los productos de PCR se analizó en geles de agarosa $1 \%$, mientras que el resto se purificó utilizando el sistema Multiscreen-PCR 96-well Filtration System (Millipore) y se resuspendió en agua hasta una concentración final de 200-400 ng/ $\mathrm{\mu l}$. Los productos de PCR purificados se transfirieron a placas de 384 pocillos (Corning) hasta una concentración de 100-200 ng/ $\mu \mathrm{l}$ en 50\% (v/v) DMSO. Además, se incluyeron los controles Lucidea Universal ScoreCard Kit (Amersham Biosciences) diluidos a $100 \mathrm{ng} / \mu \mathrm{l}$ en $50 \%(\mathrm{v} / \mathrm{v})$ DMSO para evaluar la precisión de los datos de expresión obtenidos. Los productos de PCR purificados y los controles se imprimieron en cristales de vidrio recubiertos con $\mathrm{y}$-aminopropilsilano (UltraGAPS, $25 \times 75 \mathrm{~mm}$ ) (Corning) utilizando un robot de impresión MicroGrid II (Biorobotics) en un formato de 48 bloques con $16 \times 17$ puntos por bloque con una humedad relativa constante del 45\%. Tras la impresión, el DNA se fijó a los cristales de vidrio modificados mediante $150 \mathrm{~mJ}$ de irradiación con luz ultravioleta y las micromatrices se almacenaron en un desecador (Aname).

\section{Experimentos de micromatrices de cDNA}

Los experimentos con micromatrices de cDNA comienzan con el diseño del experimento, es decir, la definición de los objetivos, la selección y la obtención del material biológico apropiado para probar la hipótesis de interés a nivel transcripcional y la decisión sobre qué muestras deben hibridarse juntas. La siguiente fase consiste en la generación de los datos e incluye la extracción de RNA, el marcaje con cada uno de los compuestos fluorescentes, la hibridación con la micromatriz y la adquisición y el análisis de la imagen. El análisis de los datos generados incluye dos etapas: 1) el preprocesado y normalización de los mismos, y 2) la identificación de los genes candidatos y la interpretación biológica de los datos obtenidos (Fig. 4). En este apartado se describe la metodología seguida en este trabajo en las diferentes etapas. 


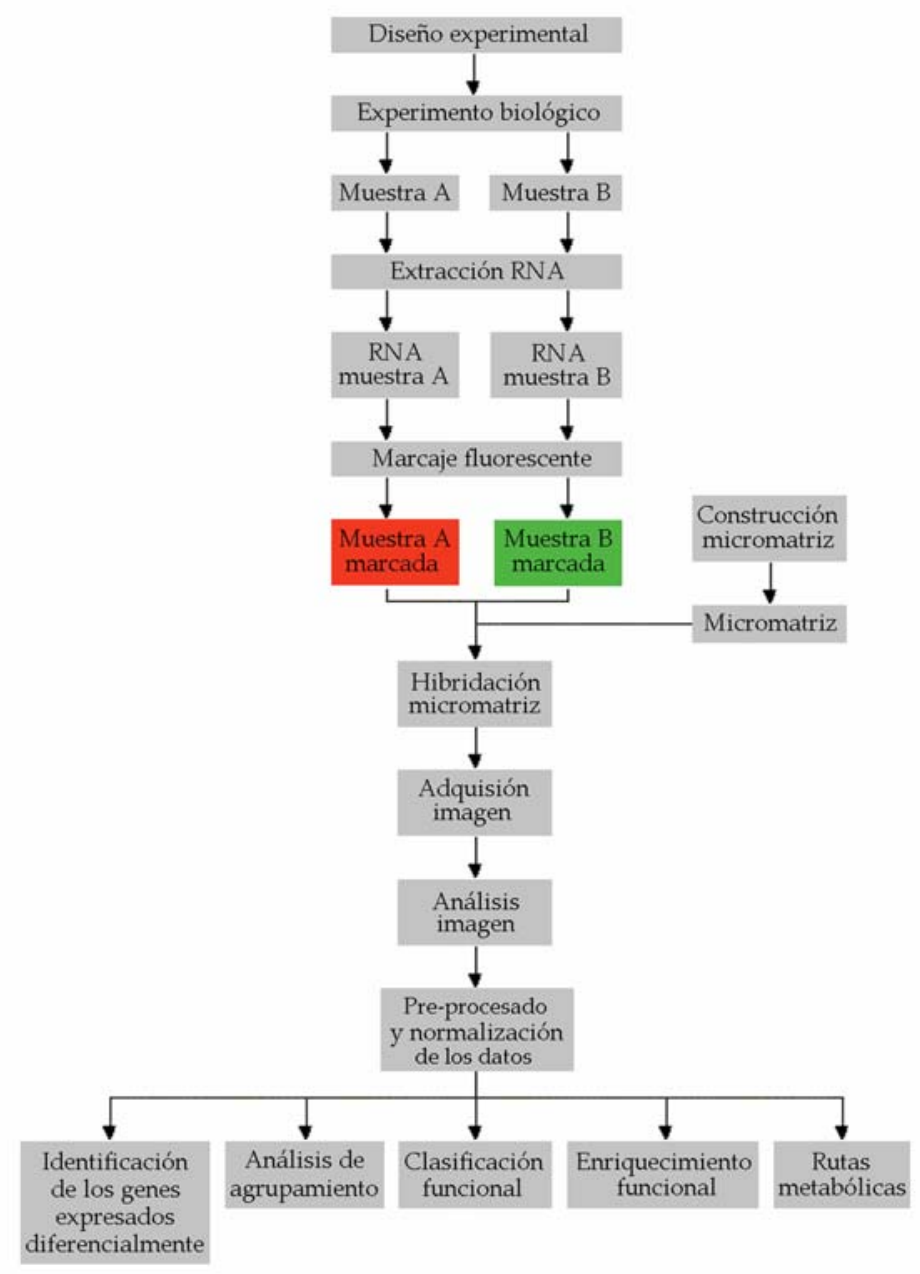

Fig. 4. Diagrama de flujo para un experimento tipo de análisis de la expresión génica mediante micromatrices de cDNA. La idea subyacente a un experimento de micromatrices de cDNA es que tras la hibridación competitiva entre la muestra marcada con el compuesto fluorescente Cy5 (rojo) y la marcada con Cy3 (verde), las medidas de fluorescencia obtenidas indican la abundancia relativa de cada transcrito correspondiente a cada sonda de la micromatriz en ambas muestras.

\subsection{Diseño de experimentos}

El principal objetivo del diseño de experimentos es que tanto el análisis de los datos como la interpretación de los resultados sea lo más simple y potente posible. La propiedad principal de los datos generados en un experimento de micromatrices de cDNA es que son, inherentemente, comparativos. El aspecto más importante de los principios de diseño para estos experimentos comparativos es determinar qué muestras de RNA se marcarán con cada compuesto fluorescente, cuáles se hibridarán juntas en la misma micromatriz y cuántas réplicas se realizarán.

Las cuestiones que nos hemos planteado en estos experimentos han sido, principalmente, de dos tipos: 1) ¿qué genes cambian su expresión en la condición $x$ respecto a la condición control? y 2) ¿qué genes responden de modo similar en dos o 
más condiciones cuando se comparan con la condición control? Los diseños de experimentos que se planteraron para abordar este tipo de cuestiones responden al esquema representado en la Figura 5.

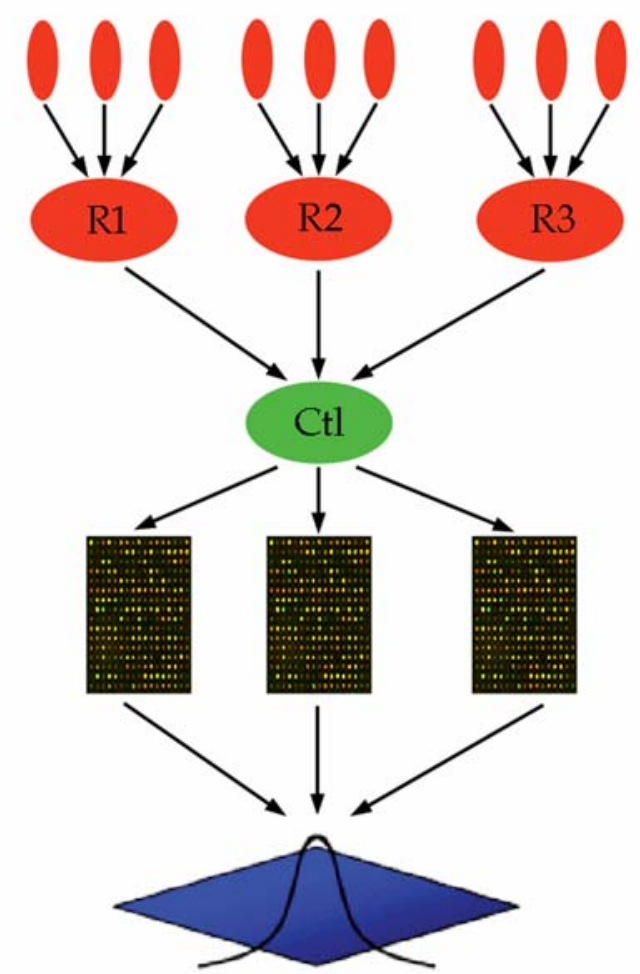

Fig. 5. Diseño de experimentos de micromatrices de cDNA. Las diferentes muestras problema (ej. brotes de un mismo individuo tratados con $\mathrm{GA}_{3}$; círculos rojos pequeños) se agrupan constituyendo una réplica biológica (R1, R2, R3) y se marcan con el compuesto fluorescente Cy5. El control (Ctl) se genera a partir de diferentes muestras y constituye la muestra de referencia, que se marca con el compuesto fluorescente Cy3. Cada una de las réplicas biológicas se compara con la referencia mediante la co-hibridación en la misma micromatriz. Los datos obtenidos se promedian (rombo azul) para generar una distribución (media, desviación) que permite estimar la variación biológica.

Las características del diseño de experimentos utilizado en este trabajo son:

1) La condición control (Ctl) se convierte en una referencia de facto con significado biológico.

2) Todas las hibridaciones implican la comparación de cada una de las diferentes condiciones estudiadas con la condición control $(\mathrm{Ctl})$. Se trata, por lo tanto, de comparaciones directas que generan una varianza inferior a la derivada de un diseño indirecto (Yang y Speed, 2002).

3) No se realizó marcaje reverso (dye-swap), es decir, hibridaciones por duplicado asignando los compuestos fluorescentes de forma opuesta en la segunda hibridación. La proporción de genes afectados por un sesgo en la incorporación de los compuestos fluorescentes se ha estimado en un $0.1 \%$ (Causton et al, 
2003). Este problema es más frecuente cuando el marcaje del cDNA se realiza con el método directo. En todos los experimentos se utilizó el método indirecto de marcaje del cDNA (ver apartado 6.2.1) de modo que la proporción de genes potencialmente afectados por este problema es baja.

4) En los experimentos de micromatrices de cDNA se realizaron, al menos, tres réplicas de acuerdo con Lee et al (2000). Las repeticiones se realizaron partiendo de diferentes muestras biológicas (Fig. 5) por lo que se trata de réplicas biológicas ( $R 1, R 2, R 3)$. Este tipo de réplicas implica un mayor grado de variación en los resultados obtenidos pero permite generalizar las conclusiones extraídas del experimento.

\subsection{Preparación de muestras de cDNA marcadas}

\subsubsection{Marcaje mediante el método indirecto}

El marcaje de las muestras de RNA para la hibridación de las micromatrices se realizó mediante el método indirecto. Este método utiliza nucleótidos dUTP modificados con un grupo aminoalilo [5-(3-aminoalilo)-2-deoxi-UTP, aa-dUTP] que se incorporan en la cadena de cDNA sintetizada durante la transcripción reversa. Por otro lado, los compuestos fluorescentes Cy3 y Cy5 utilizados contienen un grupo reactivo $\mathrm{N}$-hidroxi-succinimida (NHS) de modo que el cDNA queda marcado por la reacción de estos grupos NHS con los grupos aminoalilo. El método indirecto que se utilizó es básicamente el descrito por The Institute for Genomic Research (TIGR; http://www.arabidopsis.org). La síntesis de cDNA se realizó utilizando $30 \mu \mathrm{g}$ de RNA total (ver apartado 2.1.1), tratado $10 \mathrm{~min}$ a $70^{\circ} \mathrm{C}$ para relajar la estructura secundaria, y $400 \mathrm{U}$ de transcriptasa reversa SuperScript III (Invitrogen), en presencia de $334 \mu \mathrm{M}$ aa-UTP (Sigma), $6 \mu$ g oligo(dT) $24,500 \mu \mathrm{M}$ de dATP, dCTP y dGTP, $166 \mu \mathrm{M}$ dTTP y 10 $\mu \mathrm{M}$ DTT en un volumen final de $30 \mu \mathrm{l}$, durante $3 \mathrm{~h}$ a $50^{\circ} \mathrm{C}$. Las muestras se incubaron con $250 \mu \mathrm{M} \mathrm{NaOH}$ y $125 \mu \mathrm{M}$ EDTA durante $15 \mathrm{~min}$ a $65^{\circ} \mathrm{C}$ y se neutralizaron con 250 $\mu \mathrm{M} \mathrm{HCl}$. La reacción de cDNA se purificó en una columna Qiaquick (Qiagen) para eliminar aa-dUTP no incorporado. El cDNA modificado con aa-dUTP se secó, se resuspendió en $10 \mu \mathrm{NaHCO}_{3} 100 \mathrm{mM}$ pH 9 y se incubó 1 h en oscuridad con los compuestos fluorescentes Cy3 ó Cy5 CyDye NHS-éster (Amersham Biosciences), con objeto de que los grupos NHS-éster de los compuestos fluorescentes reaccionen formando enlaces covalentes con los grupos aminoalilo del cDNA modificado. El cDNA marcado con los compuestos fluorescentes se purificó nuevamente con una columna Qiaquick (Qiagen) siguiendo las instrucciones del fabricante. 


\subsubsection{Caracterización de las propiedades del cDNA marcado}

La calidad del cDNA marcado, tanto el tamaño de los fragmentos obtenidos como la eficiencia del marcaje, se estimó mediante electroforesis en geles de agarosa $1 \%$ y TAE 1X de una alícuota de cada muestra, utilizando el sistema de electroforesis BioRad Miniprotean (Bio-Rad Laboratories). Para ello, el cDNA marcado se secó, se resuspendió en $10 \mu \mathrm{l}$ de agua y una alícuota (1/10 del total) se cargó junto a $5 \mu \mathrm{l}$ de glicerol $15 \%$. Tras la electroforesis, el gel se colocó sobre un portaobjetos de cristal, se deshidrató y se escaneó utilizando el escáner GenePix 4000B y el programa asociado GenePix 4.1 (Molecular Devices) (Fig. 6A). La cantidad de compuesto fluorescente incorporado se determinó con un espectrofotómetro NanoDrop ND-100 (NanoDrop Technologies), midiendo la absorbancia de las muestras de cDNA marcadas a las longitudes de onda de $550 \mathrm{~nm}$ y $650 \mathrm{~nm}$, que corresponden con la máxima absorción para Cy3 y Cy5, respectivamente (Fig. 6B).
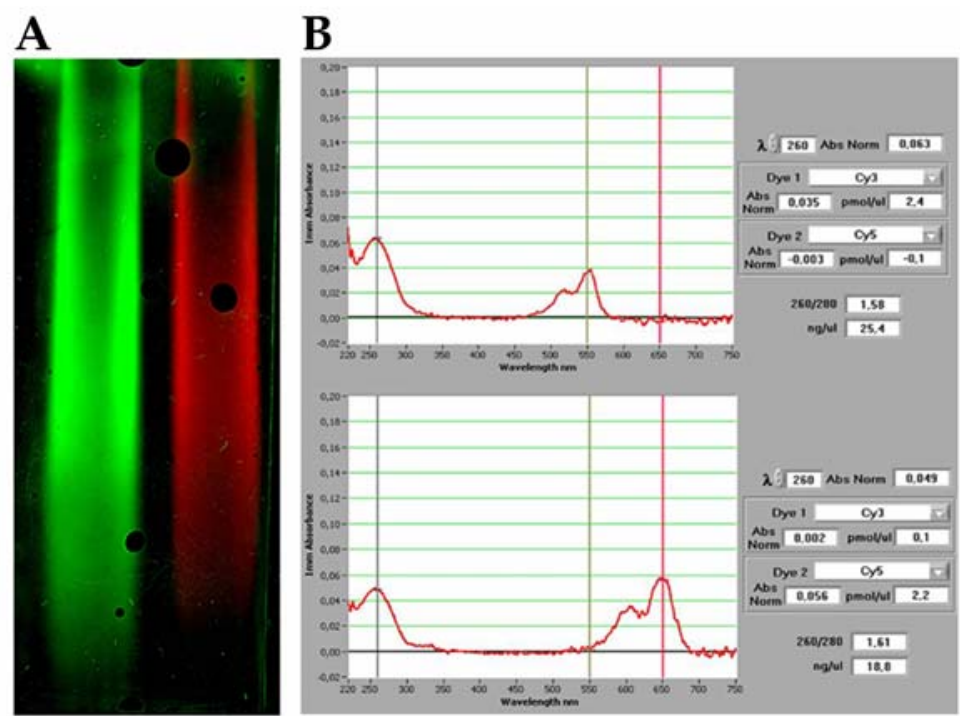

Fig. 6. Caracterización de las propiedades del cDNA marcado. La electroforesis en geles de agarosa $1 \%$ (A) permitió estimar la eficiencia del marcaje con los compuestos fluorescentes Cy3 (carril izquierdo) y Cy5 (carril derecho). La cantidad de cDNA marcado se determinó por espectrofotometría (B), tanto para Cy3 (panel superior) como para Cy5 (panel inferior).

\subsection{Hibridación de las micromatrices}

La hibridación de las micromatrices se realizó siguiendo los protocolos de hibridación recomendados para UltraGAPS Coated Slides (Corning), que es el soporte que se utilizó para la construcción de la micromatriz CIT1 (ver apartado 5). 


\subsubsection{Protocolo de hibridación A}

\section{Pre-hibridación}

Las micromatrices se pre-hibridan con el objetivo doble de bloquear la superficie libre de la micromatriz para minimizar el ruido de fondo y de eliminar las sondas de DNA mal adheridas para maximizar la señal de hibridación. La pre-hibridación se realizó en solución SSC 3X (Sigma), 0.1\% SDS (Sigma) y $0.1 \mathrm{mg} / \mathrm{ml}$ BSA durante $60 \mathrm{~min}$ a $50^{\circ} \mathrm{C}$. Las micromatrices pre-hibridadas se lavaron a temperatura ambiente durante $15 \mathrm{~s}$ en agua y $2 \mathrm{~min}$ en isopropanol. Las micromatrices se secaron por centrifugación a 1,500 rpm durante 5 min.

\section{$\underline{\text { Hibridación }}$}

Las micromatrices se hibridaron manualmente utilizando las cámaras de hibridación Arraylt (Telechem International). Para ello, las muestras de cDNA marcadas, bien con el compuesto fluorescente Cy3 o bien con Cy5, se secaron por separado, se resuspendieron en la solución de hibridación compuesta por SSC 3X (Sigma), 0.1\% SDS (Sigma) y $0.1 \mathrm{mg} / \mathrm{ml}$ DNA de esperma de salmón (Stratagene) en un volumen final de $80 \mu \mathrm{l}$, y se incubaron $1 \mathrm{~min}$ a $95^{\circ} \mathrm{C}$. Las muestras desnaturalizadas permanecieron a temperatura ambiente protegidas de la luz directa. Las cámaras de hibridación se precalentaron a $50^{\circ} \mathrm{C}$ y se añadió $50 \mu \mathrm{l}$ de agua en cada uno de los pocillos de la cámara y otros $50 \mu \mathrm{l}$ repartidos en tres puntos en la parte central. En la cámara precalentada se depositó la micromatriz que se cubrió con un cristal LifterSlip (Erie Scientific). Las muestras se inyectaron desde la parte inferior de la micromatriz de modo que el espacio de la hibridación se rellena por capilaridad. Una vez aplicadas las muestras a las cámaras de hibridación, éstas se cerraron y la hibridación se realizó en un baño de agua a $50^{\circ} \mathrm{C}$ durante toda la noche en oscuridad.

\section{$\underline{\text { Lavados }}$}

Tras la hibridación, las micromatrices se lavaron secuencialmente, con agitación, en SSC $2 X$ (Sigma), $0.1 \%$ SDS (Sigma) a $42^{\circ} \mathrm{C}$ durante $5 \mathrm{~min}$, en SSC $0.1 \mathrm{X}$, $0.1 \%$ SDS durante $10 \mathrm{~min}$ a temperatura ambiente, 5 veces en SSC $0.1 \mathrm{X}$ durante $1 \mathrm{~min}$ a temperatura ambiente, y finalmente en SSC $0.01 \mathrm{X}$ durante $10 \mathrm{~s}$. Las micromatrices se secaron centrifugando a 1,500 rpm durante 5 min. 


\subsubsection{Protocolo de hibridación B}

Este protocolo de hibridación presenta diversas modificaciones respecto al protocolo A, entre ellas la incorporación de $50 \%(\mathrm{v} / \mathrm{v})$ formamida en la solución de hibridación. En la realización de este trabajo se ha comprobado que la utilización de este protocolo supone una mejora substancial de la hibridación, evaluada mediante los parámetros de calidad obtenidos durante el análisis de los datos (ver apartado 6.6.1). De hecho, las recomendaciones del fabricante de UltraGAPS Coated Slides (Corning) actualmente sólo incorporan este protocolo de hibridación.

\section{Pre-hibridación}

La pre-hibridación se realizó en tampón SSC 5X (Sigma), 0.1\% SDS (Sigma) y $0.1 \mathrm{mg} / \mathrm{ml} \mathrm{BSA}$ durante $60 \mathrm{~min}$ a $42^{\circ} \mathrm{C}$. Las micromatrices pre-hibridadas se lavaron dos veces en SSC 0.1X a temperatura ambiente durante 5 min y una vez en agua a temperatura ambiente durante $30 \mathrm{~s}$. Las micromatrices se secaron centrifugando a 1,600 rpm durante 2 min.

\section{$\underline{\text { Hibridación }}$}

Las micromatrices se hibridaron manualmente utilizando las cámaras de hibridación Arraylt (Telechem International). Para ello, las muestras de cDNA marcadas, bien con el compuesto fluorescente Cy3 o bien con Cy5, se resuspendieron en una solución de hibridación fresca que contiene $50 \%$ formamida (v/v), SSC 5X (Sigma), $0.1 \%$ SDS (Sigma) y $0.1 \mathrm{mg} / \mathrm{ml}$ DNA de esperma de salmón (Stratagene) en un volumen final de $80 \mu \mathrm{l}$, y se incubaron $2 \min$ a $95^{\circ} \mathrm{C}$. Las muestras desnaturalizadas permanecieron a temperatura ambiente protegidas de la luz directa. La hibridación se realizó tal como se ha descrito en el protocolo $\mathrm{A}$ con la única modificación de que la temperatura de hibridación fue de $42^{\circ} \mathrm{C}$.

\section{Lavados}

Tras la hibridación, las micromatrices se lavaron secuencialmente, con agitación, en SSC $2 X$ (Sigma), $0.1 \%$ SDS (Sigma) a $42^{\circ} \mathrm{C}$ durante $5 \mathrm{~min}$, dos veces en SSC $0.1 \mathrm{X}, 0.1 \%$ SDS durante $5 \mathrm{~min}$ a temperatura ambiente, 5 veces en SSC $0.1 \mathrm{X}$ durante $1 \mathrm{~min}$ a temperatura ambiente, y finalmente en SSC $0.01 \mathrm{X}$ durante $10 \mathrm{~s}$. Las micromatrices se secaron por centrifugación a 1,600 rpm durante 2 min. 


\subsection{Adquisición y análisis de la imagen}

El primer paso en el análisis de los datos es el escaneado de la micromatriz y la extracción de los datos de intensidad de las imágenes. En el proceso de adquisición y análisis de la imagen hay cuatro pasos básicos: 1) escaneado, 2) reconocimiento de cada punto o gridding, 3) segmentación y 4) extracción de la intensidad y cálculo del cociente de expresión.

Las micromatrices se escanearon con un escáner GenePix 4000B (Molecular Devices) utilizando dos versiones del programa asociado: GenePix 4.1 y GenePix 6.0 (empleado en los experimentos de micromatrices de la última parte de este trabajo) y con unos parámetros de excitación a 532 y $635 \mathrm{~nm}$ para Cy3 y Cy5, respectivamente, resolución de $10 \mu \mathrm{m}$ y potencia del láser del 100\%. Cuando se utilizó el programa GenePix 4.1, los valores de ganancia del tubo fotomultiplicador (PMT) se ajustaron manualmente de modo que la intensidad global de la señal adquirida en cada canal (Cy3 y Cy5) fuera similar. Este ajuste se consiguió cuando los histogramas de distribución de los píxel (Fig. 7) en cada canal solapan, de modo que el cociente entre ambos es, aproximadamente, igual a 1. Al mismo tiempo, el número de elementos con píxel saturados se minimizó (unos 10 elementos de los 12,672 contenidos en la micromatriz CIT1) con el objetivo de maximizar el rango dinámico del escáner. El programa GenePix 6.0 permite realizar un ajuste automático de los valores de ganancia de PMT una vez fijada la proporción de píxel saturados. En nuestro caso, se utilizó un valor de saturación del $0.04 \%$.

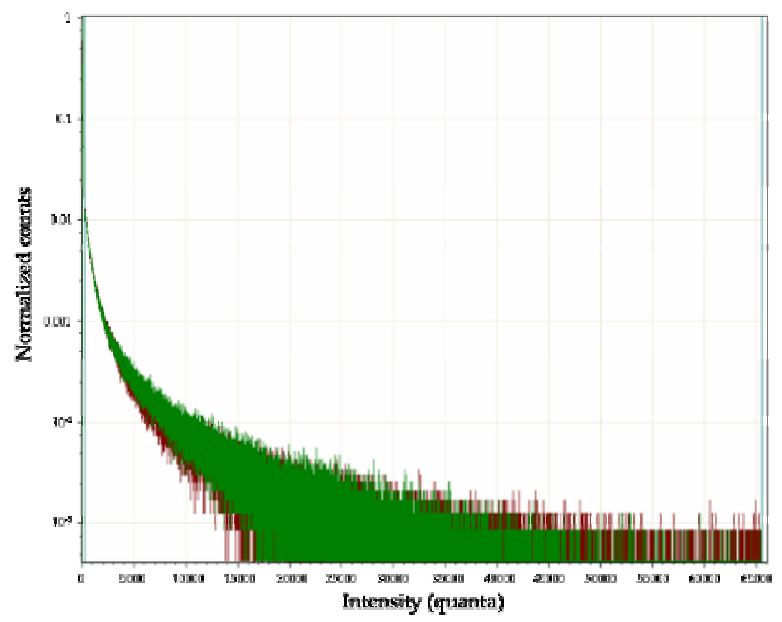

Fig. 7. Histograma de la distribución de píxel de cada canal, Cy3 (verde) y Cy5 (rojo). El ajuste de los histogramas de distribución de los píxel se consigue cuando éstos solapan. 
El reconocimiento de los puntos o gridding es el proceso computacional que permite localizar cada punto de la micromatriz en la imagen obtenida. Para ello, un fichero GAL (GenePix Array List) o gradilla de reconocimiento queda superpuesto a la imagen. Este fichero se genera durante el proceso de impresión de la micromatriz (ver apartado 5), está organizado en bloques y contiene la información referente a la posición de cada punto, un identificador (ID) único para cada punto y la descripción de cada ID, entre otros campos. Se realizó un ajuste general de la gradilla de forma automática y un ajuste más preciso de cada bloque de forma manual que permitió, adicionalmente, marcar los puntos de mala calidad (intensidad heterogénea, morfología aberrante), quedando así eliminados de posteriores análisis.

La segmentación es el proceso que permite diferenciar, para cada punto de la micromatriz, los píxel que forman parte de la señal verdadera de intensidad (foreground: F635, F532) de los píxel que constituyen la señal de fondo (background: B635, B532). El algoritmo utilizado en el proceso de segmentación fue el de segmentación circular adaptativo de modo que a cada punto de la micromatriz se le aplicó un círculo de diámetro variable que contenía los píxel que forman parte de la señal de intensidad. La estimación de la señal de fondo se realizó mediante el método local que utiliza, para cada punto, la intensidad de los píxel que rodean el círculo establecido en la segmentación. Tras el proceso de segmentación, se calcularon dos valores de intensidad para cada punto de la micromatriz y para cada canal, la intensidad de la señal (como la mediana de la intensidad de los píxel que constituyen la señal: F635Median y F532Median) y la intensidad del fondo (como la mediana de la intensidad de los píxel que constituyen el fondo: B635Median, B532Median). La intensidad neta o corregida de cada punto se obtuvo mediante la sustracción de la intensidad del fondo a la intensidad de la señal en cada canal. Los cocientes de expresión entre ambos canales se calcularon utilizando las intensidades netas o corregidas, es decir,

Ratio of Medians $=($ F635Median - B635Median $) /($ F532Median - B532Median $)$

\subsection{Pre-procesado y normalización de los datos}

Los datos extraídos durante el análisis de la imagen deben ser pre-procesados para excluir los puntos de baja calidad y normalizados para eliminar los errores sistemáticos generados en el proceso. El pre-procesado de los datos consistió en eliminar todos aquellos puntos de la micromatriz cuya intensidad neta fue menor a dos veces el valor medio del fondo global de la micromatriz en los dos canales. Es decir, 


$$
\begin{aligned}
& \text { Flag }=\left[(\text { F635Mediana }- \text { B635Mediana }) \leq 2 \times \text { FondoGlobal }_{635}\right] \mathrm{y} \\
& \text { [(F532Mediana - B532Mediana } \left.) \leq 2 \times \text { FondoGlobal }_{532}\right]
\end{aligned}
$$

Los puntos de la micromatriz que cumplieron la citada condición quedaron eliminados para los análisis posteriores. Los cocientes de expresión se transformaron en logaritmo en base dos $\left(\log _{2}\right)$, de modo que la interpretación biológica de los valores de expresión es más sencilla ya que esta transformación permite comparar, en la misma escala, los valores de inducción y los de represión. La normalización es el proceso por el que la variación sistemática debida a causas no biológicas se minimiza y se estandariza (Fig. 8). Este tipo de variación tiene que ver con factores técnicos como las diferencias en la cantidad de la muestra marcada o en la incorporación de los dos compuestos fluorescentes (Cy3, Cy5), la sensibilidad de los mismos a la luz o al calor, así como los parámetros del escaneado de ambos canales (Leung y Cavalieri, 2003).

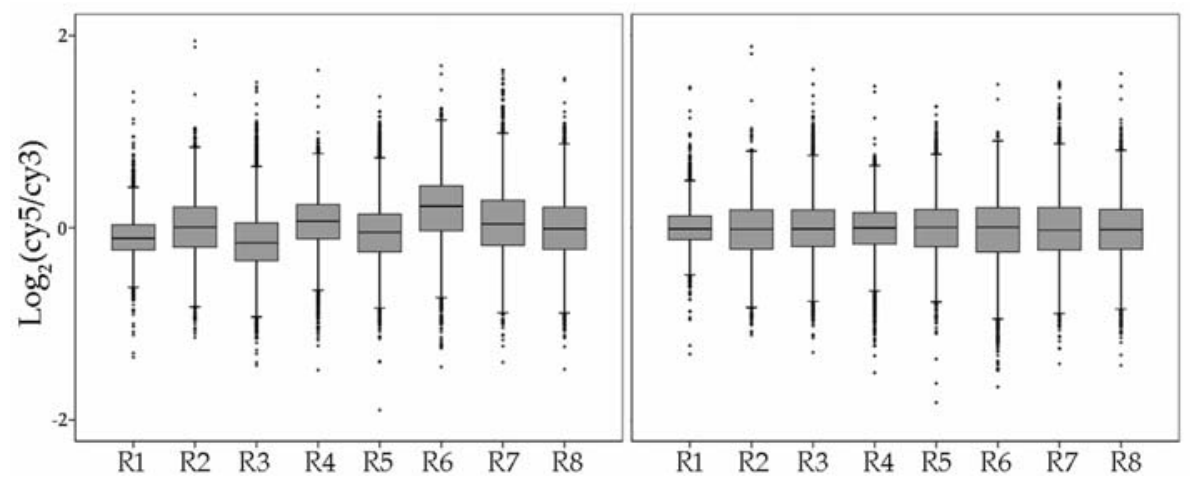

Fig. 8. Normalización global. El panel de la izquierda muestra los diagramas de caja correspondientes a los datos de expresión, $\log _{2}$ (Cy5/Cy3), en las diferentes réplicas de uno de los experimentos realizados en este trabajo, antes de la normalización. El panel de la derecha muestra los diagramas de caja correspondientes a los mismos datos tras la normalización global.

En un experimento de micromatrices cabe esperar que la mayoría de los genes analizados no cambien su expresión, es decir, que la distribución de los valores de expresión, $\log _{2}$ (Сy5/Cy3), tenga por media el valor cero. La distribución se centró en cero mediante una normalización lineal global. Así pues, todos los puntos se corrigieron por el mismo factor de modo que la forma de la distribución no varió (Fig. 8). La normalización permite comparar los resultados obtenidos en las diferentes micromatrices de un experimento. Los valores correspondientes a $\log _{2}$ (Cy5/Cy3) pueden tener una dependencia sistemática según la intensidad, que se manifiesta como una desviación respecto al cero para los valores de baja intensidad (Causton 
et al, 2003). La transformación de los datos mediante la función Lowess (Locally weighted polynomial regression) ha sido propuesta como un método de normalización para los experimentos con micromatrices que corrige este efecto (Yang et al, 2002). Los datos de micromatrices obtenidos en este trabajo se normalizaron mediante la función Lowess utilizando el programa Acuity (Molecular Devices) (Fig. 9).

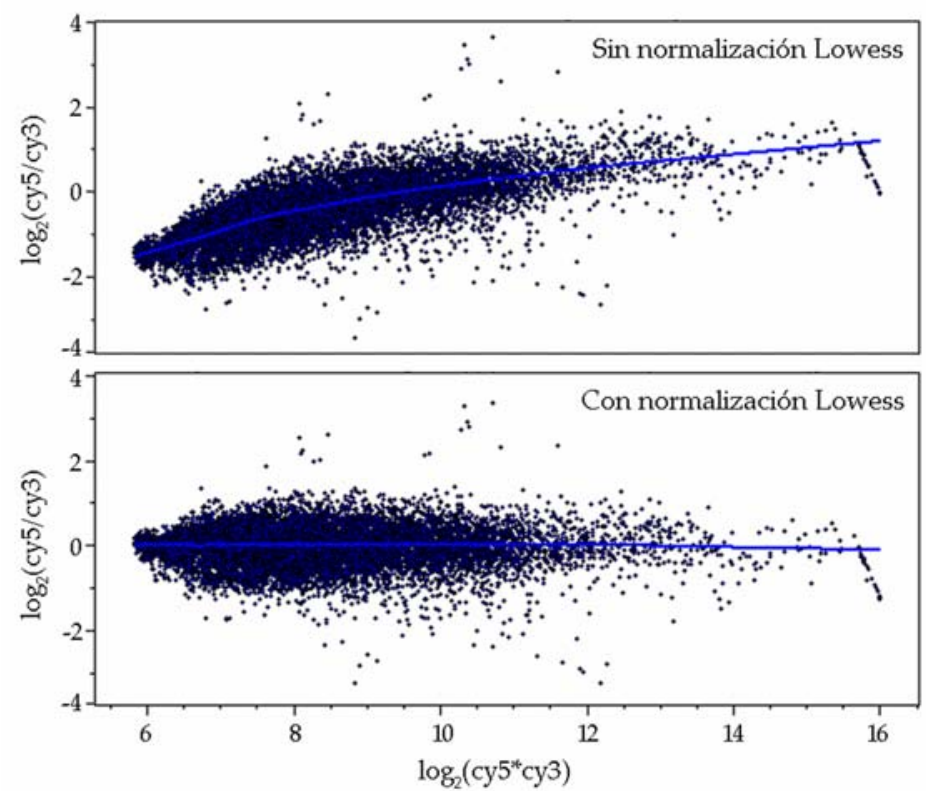

Fig. 9. Normalización Lowess. La representación de los datos de expresión, $\log _{2}$ (Cy5/Cy3), respecto a la suma de las intensidades de ambos canales, $\log _{2}$ Cy5 $+\log _{2}$ Cy3, permite observar la desviación de la distribución respecto a cero a bajas intensidades (panel superior). Este efecto es minimizado mediante la transformación Lowess de los datos (panel inferior).

\subsection{Evaluación de la calidad de los datos obtenidos con micromatrices}

\subsubsection{Parámetros de calidad de GenePix}

El programa de análisis de imágenes de micromatrices, GenePix (Molecular Devices), permite realizar un 'control de calidad de cada micromatriz' mediante un análisis estadístico de los datos y el cálculo de diversos parámetros que permiten estimar la calidad de los datos obtenidos en cada micromatriz. En la realización de este trabajo, se observó que los valores obtenidos para los parámetros de calidad varían substancialmente según el protocolo de hibridación empleado (Tabla 2). Las diferencias más notables se refieren a una reducción de la señal de fondo (procedente de la unión inespecífica de la sonda), especialmente en el canal de Cy3 (532 nm), de modo que el valor medio del fondo se redujo, al menos, a la mitad utilizando el protocolo de hibridación B (ver apartado 6.3.2). Esta reducción conllevó un aumento 
en la relación señal-fondo y una reducción en la proporción de puntos cuya señal no se detecta, es decir, que no superan el criterio establecido en el apartado 6.5. La mejora en la calidad de los datos obtenidos con el protocolo de hibridación B nos llevó a utilizar este método en los sucesivos experimentos de micromatrices.

\begin{tabular}{|c|c|c|c|c|c|}
\hline \multicolumn{6}{|l|}{ Protocolo A } \\
\hline & \multirow{2}{*}{ Cy5 (635) } & \multirow{2}{*}{ Cy3 (532) } & \multirow{2}{*}{ Threshold } & \multicolumn{2}{|c|}{ Results } \\
\hline & & & & 635 & 532 \\
\hline Median signal-to-background & 10.3 & 6.5 & $>10$ & Pass & Fail \\
\hline Mean of median background & 130.054 & 220.07 & $<500$ & Pass & Pass \\
\hline Median signal-to-noise & 35.5 & 17.3 & $>10$ & Pass & Pass \\
\hline Feature variation & 0.289 & 0.295 & $<0.5$ & Pass & Pass \\
\hline Background variation & 0.436 & 0.508 & $<0.5$ & Pass & Fail \\
\hline Features with saturated píxel & 1.7 & 0.63 & $<1 \%$ & Fail & Fail \\
\hline Not Found features & \multicolumn{2}{|c|}{$2127 / 12767(16.6 \%)$} & $<10 \%$ & \multicolumn{2}{|c|}{ Fail } \\
\hline Bad features & \multicolumn{2}{|c|}{$7 / 12767(0.1 \%)$} & $<7 \%$ & \multicolumn{2}{|c|}{ Pass } \\
\hline \multicolumn{6}{|l|}{ Protocolo B } \\
\hline & \multirow{2}{*}{ Cy5 (635) } & \multirow{2}{*}{ Су3 (532) } & \multirow{2}{*}{ Threshold } & \multicolumn{2}{|c|}{ Results } \\
\hline & & & & 635 & 532 \\
\hline Median signal-to-background & 15 & 15.3 & $>10$ & Pass & Pass \\
\hline Mean of median background & 60.002 & 57.448 & $<500$ & Pass & Pass \\
\hline Median signal-to-noise & 57.3 & 59.6 & $>10$ & Pass & Pass \\
\hline Feature variation & 0.298 & 0.302 & $<0.5$ & Pass & Pass \\
\hline Background variation & 0.301 & 0.428 & $<0.5$ & Pass & Pass \\
\hline Features with saturated píxel & $0.22 \%$ & $0.06 \%$ & $<1 \%$ & Pass & Pass \\
\hline Not Found features & \multicolumn{2}{|c|}{$1148 / 12767(9 \%)$} & $<10 \%$ & \multicolumn{2}{|c|}{ Pass } \\
\hline Bad features & \multicolumn{2}{|c|}{$8 / 12767(0.1 \%)$} & $<7 \%$ & \multicolumn{2}{|c|}{ Pass } \\
\hline
\end{tabular}

\subsubsection{Validación técnica de la micromatriz CIT1}

Los controles Lucidea Universal ScoreCard Kit (Amersham Biosciences), distribuidos en la micromatriz CIT1 (Tabla 3), permitieron estimar el rango dinámico, los niveles de sensibilidad y la reproducibilidad intra-array.

Tabla 3. Controles Lucidea distribuidos en la micromatriz CIT1

\begin{tabular}{lllrrr}
\hline \multirow{2}{*}{ Tipo de control } & \multirow{2}{*}{ Nombre } & \multirow{2}{*}{ ID cDNA } & \multicolumn{2}{c}{ mRNA en la muestra $(\mathrm{pg} / \mu \mathrm{l})$} & Cociente de \\
\cline { 4 - 5 } & & Test & Referencia & expresión \\
\hline Calibración & Cal2 & cYIR02 & 5000 & 5000 & $1: 1$ \\
Calibración & Cal3 & cYIR03 & 1500 & 1500 & $1: 1$ \\
Calibración & Cal4 & cYIR04 & 500 & 500 & $1: 1$ \\
Calibración & Cal6 & cYIR05 & 50 & 50 & $1: 1$ \\
Calibración & Cal7 & cYIR07 & 15 & 15 & $1: 1$ \\
Calibración & Cal8 & cYIR08 & 5 & 5 & $1: 1$ \\
Calibración & Cal9 & cYIR09 & 1.5 & 1.5 & $1: 1$ \\
Ratio & Ratio1 & rYIR1 & 50 & 150 & $1: 3$ Bajo \\
Ratio & Ratio2 & rYIR2 & 150 & 50 & $3: 1$ Bajo \\
Ratio & Ratio3 & rYIR3 & 500 & 1500 & $1: 3$ Alto \\
Ratio & Ratio4 & rYIR4 & 1500 & 500 & $3: 1$ Alto \\
Negativo & Negativ01 & nYIR1 & 0 & 0 & 0 \\
\hline
\end{tabular}


Estos controles son genes artificiales diseñados a partir de regiones intergénicas de levadura de tres tipos: 1) controles de calibración que permiten evaluar el rango dinámico y la sensibilidad del sistema; 2) controles de ratio que representan niveles de expresión bajos y altos; y 3) controles negativos que permiten evaluar los niveles de intensidad correspondientes a hibridación no específica. Los datos de expresión correspondientes a estos genes se obtuvieron añadiendo en cada reacción

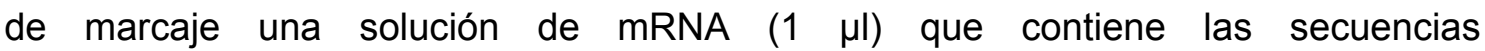
complementarias a los cDNAs depositados en la micromatriz CIT1.

\subsection{Identificación de los genes expresados diferencialmente}

La identificación de los genes expresados diferencialmente en los experimentos de micromatrices se realizó mediante dos métodos según el número de réplicas realizadas en cada experimento: 1 ) el test de la $t$ de Student en experimentos con tres réplicas biológicas y 2) el análisis SAM (Significance Análisis of Microarrays) (Tusher et al, 2001), en experimentos de dos clases de más de tres réplicas biológicas o en experimentos de múltiples clases con tres réplicas por clase.

\subsubsection{Test de la $t$ de Student}

Para cada uno de los genes que componen la micromatriz CIT1 se calculó el estadístico $t$ para comprobar la hipótesis nula 'no existen diferencias de expresión entre las condiciones comparadas' utilizando el programa Acuity (Molecular Devices). El estadístico $t$ se define como $t=\mathrm{R}_{\mathrm{g}} / \mathrm{SE}_{\mathrm{g}}$, siendo $\mathrm{R}_{\mathrm{g}}$ la media de los cocientes de expresión (expresados en $\log _{2}$ ) de las réplicas y $\mathrm{SE}_{\mathrm{g}}$ el error estándar. Una vez calculado el estadístico $t$ para cada uno de los genes, se convirtió en un valor de probabilidad $p$ según la tabla de la distribución $t$ de Student. Un inconveniente de este método es el de la estabilidad, es decir, que genes cuyo SE sea, por azar, pequeño obtendrán valores del estadístico $t$ elevados, incluso cuando el valor de $\mathrm{R}_{\mathrm{g}}$ sea bajo. Este método se utilizó para identificar los genes expresados diferencialmente en el análisis del transcriptoma de las plantas transgénicas que sobre-expresan el gen CcGA200x1.

\subsubsection{Análisis SAM}

El análisis SAM constituye una versión modificada del test de la $t$ de Student en el que se añade una constante en el denominador de modo que el estadístico se 
define como $s=R_{g} / c+S E_{g}$, siendo c la constante. La adición de dicha constante reduce el problema de la estabilidad anteriormente señalado. En este método el estadístico $s$ se convierte en un valor $q$ mediante un análisis de permutaciones (Tusher et al, 2001) lo que exige un número suficiente de réplicas, al menos cuatro en el caso de comparaciones de dos clases. Este método se utilizó para identificar los genes expresados diferencialmente en el resto de los análisis transcriptómicos realizados en este trabajo.

\subsubsection{El problema de las pruebas múltiples}

Cada vez que se realiza un test estadístico se pueden cometer dos tipos de errores. El error de tipo I, o falso positivo, ocurre cuando se declara un gen como diferencialmente expresado cuando en realidad su expresión no es diferencial. El error de tipo II, o falso negativo, sucede cuando un gen que verdaderamente se expresa diferencialmente no se declara como tal. En un experimento de micromatrices se llevan a cabo miles de pruebas estadísticas (una por cada gen) con lo que se pueden acumular un número elevado de falsos positivos. Este problema se conoce como el problema de las pruebas múltiples. La corrección del valor $p$ obtenido en el test $t$ se realizó mediante el método de FDR (Benjamini y Hochberg, 1995) utilizando el programa Acuity (Molecular Devices). EI FDR se define como la proporción esperada de falsos positivos entre los genes identificados como diferencialmente expresados. El valor $q$ obtenido con el análisis SAM constituye una estimación del FDR. Así pues, se consideraron genes expresados diferencialmente aquéllos con un FDR inferior al $5 \%$. Adicionalmente, se aplicó un límite en el valor de cambio de expresión de al menos 1.6 veces $\left(\mid \log _{2}(\mathrm{Cy} 5 /\right.$ Cy3 $\left.) \mid \geq 0.678\right)$ de modo que el análisis fue más estricto.

\subsection{Análisis de agrupamiento y análisis funcional de los datos}

El análisis de agrupamiento jerárquico de los diferentes tejidos de cítricos, en función de los perfiles de expresión génica, se realizó en Acuity (Molecular Devices) con el método UPGMA (Unweighted Pair-Group Method with Arithmetic Mean) utilizando los parámetros de ligamiento completo y correlación de Pearson centrada aplicados a los valores de expresión normalizados con la función Lowess y expresados en $\log _{2}$.

El conjunto de los unigenes expresados diferencialmente, identificados en cada uno de los experimentos de micromatrices realizados en este trabajo, se analizó funcionalmente para facilitar la interpretación biológica de los resultados obtenidos. El 
procedimiento seguido fue similar al descrito en el apartado 4.3.2. Para cada unigen de cítricos expresado diferencialmente se obtuvo el código AGI correspondiente al gen de Arabidopsis más similar y, a través de dicho código, la anotación funcional del MIPS mediante la herramienta FunCat (Ruepp et al, 2004) y las categorías GO con el programa FatiGO (Al-Shahrour et al, 2004). Además, el programa FatiGO se utilizó en los análisis de enriquecimiento funcional, comparando cada subconjunto de genes expresado diferencialmente con el conjunto de los genes representado en la micromatriz CIT1. El análisis de las rutas metabólicas representadas en el subconjunto de los unigenes expresado diferencialmente se realizó, asimismo a través del código AGI correspondiente al gen de Arabidopsis más similar. Estos códigos se utilizaron para obtener las rutas metabólicas en las que participa cada gen, se extrajeron los códigos AGI de otros genes implicados en cada ruta metabólica identificada y se comprobó si dichos genes están incluidos en la micromatriz CIT1 y si se encuentran expresados diferencialmente.

\section{Análisis de expresión de mRNA}

\subsection{Análisis Northern}

\subsubsection{Electroforesis en gel de agarosa desnaturalizante}

Las muestras de RNA total (10-20 $\mu \mathrm{g})$, en un volumen de $4 \mu \mathrm{l}$ de agua tratada con DEPC, se mezclaron con $10 \mu$ de formamida desionizada, $3.5 \mu \mathrm{l}$ de formaldehído 37\%, $1 \mu \mathrm{l}$ de tampón MOPS 20X (0.4 M MOPS pH 7, $0.16 \mathrm{M} \mathrm{NaAc,} 20$ mM EDTA), $1 \mu \mathrm{l}$ glicerol $80 \%$ y $0.3 \mu \mathrm{l}$ de una solución saturada de azul de bromofenol. La mezcla se incubó $10 \mathrm{~min}$ a $65^{\circ} \mathrm{C}$ y se enfrió en hielo. Las muestras se cargaron en un gel desnaturalizante de agarosa al 1.5\% que contenía tampón MOPS $1 \mathrm{X}$, formaldehído $1.2 \%$ y $10 \mu \mathrm{g}$ de BrEt, por cada $100 \mathrm{ml}$ de gel preparado. La electroforesis se realizó a un voltaje constante de $90 \mathrm{~V}$, en tampón MOPS $1 \mathrm{X}$, hasta que el azul de bromofenol recorrió aproximadamente $2 / 3$ del gel.

\subsubsection{Transferencia de RNA a membranas de nylon}

El gel se lavó durante 30 min en solución SSC 20X (3 M NaCl, $0.3 \mathrm{M}$ citrato sódico). Sobre el gel se colocó un fragmento de membrana de nylon neutra (Hybond-N, Amersham Biosciences) del tamaño del gel y, sobre ella, cuatro papeles Whatmann $3 \mathrm{MM}$, una capa de unos $5 \mathrm{~cm}$ de papel absorbente y un ligero peso. La 
transferencia por capilaridad se llevó a cabo durante toda la noche. Al finalizar, el RNA se fijó a la membrana mediante irradiación con luz ultravioleta en un UV Stratalinker 1800 (Stratagene).

\subsubsection{Obtención de las sondas de DNA}

Las sondas de DNA se obtuvieron mediante reacciones de PCR a partir de $4 \mathrm{ng}$ de DNA plasmídico utilizando $5 \mathrm{U}$ de polimerasa Expand High Fidelity (Roche Applied Science), $200 \mu \mathrm{M}$ dNTPs, 400 nM de cebador T7 modificado (5'-CGACTCACT ATAGGGCGAATTGG-3') y 400 nM de cebador T3 modificado (5'-GGAAACAGCTAT GACCATGATTAC-3'), en un volumen final de $100 \mu \mathrm{l}$. Las condiciones de las reacciones de PCR fueron de $94^{\circ} \mathrm{C}$ durante $3 \mathrm{~min}$, seguido de 5 ciclos de amplificación $\left(94^{\circ} \mathrm{C}\right.$ durante $30 \mathrm{~s}, 66^{\circ} \mathrm{C}$ durante $30 \mathrm{~s}, 72^{\circ} \mathrm{C}$ durante $\left.2 \mathrm{~min}\right), 30$ ciclos más $\left(94^{\circ} \mathrm{C}\right.$ durante $30 \mathrm{~s}, 60^{\circ} \mathrm{C}$ durante $30 \mathrm{~s}, 72^{\circ} \mathrm{C}$ durante $2 \mathrm{~min}$ ) e incubadas a $72^{\circ} \mathrm{C}$ durante $10 \mathrm{~min}$. Los productos de PCR se analizaron en geles de agarosa $1 \%$, obteniéndose bandas únicas del tamaño esperado, se purificaron utilizando el sistema QIAquick $P C R$ Purification Kit (Qiagen) y se resuspendieron en agua hasta una concentración final de $200 \mathrm{ng} / \mu \mathrm{l}$.

\subsubsection{Hibridación con sondas radiactivas}

El marcaje de las sondas de DNA con el isótopo radiactivo se realizó utilizando el sistema Ready-To-Go DNA Labelling Beads (-dCTP) (Amersham Biosciences), basado en el método de anillamiento de cebadores al azar. Alícuotas de 50 ng de DNA se diluyeron en $45 \mu \mathrm{l}$ de agua estéril y se incubaron a $95^{\circ} \mathrm{C}$ durante 3 min para su desnaturalización. La solución de DNA se añadió al tubo que contenía los componentes liofilizados necesarios para la síntesis de la sonda, al que también se añadió $5 \mu \mathrm{l}$ de $\left[\alpha^{32} \mathrm{P}\right] \mathrm{dCTP} 10 \mu \mathrm{Ci} / \mu \mathrm{l}$ (Amersham Biosciences) y se incubó a $37^{\circ} \mathrm{C}$ durante $1 \mathrm{~h}$. El DNA marcado se purificó mediante cromatografía de exclusión molecular en Sephadex G-50 (Amersham Biosciences). La sonda purificada se incubó a $95^{\circ} \mathrm{C}$ durante 3 min antes de añadirla a la solución de hibridación.

Las membranas se pre-hibridaron a $42^{\circ} \mathrm{C}$ durante 30 min con tampón de hibridación (0.25 $\mathrm{M} \mathrm{Na}_{2} \mathrm{HPO}_{4} / \mathrm{Na}_{2} \mathrm{PO}_{4} \mathrm{pH} 7.2,7 \%$ SDS, 1 mM EDTA, 8\% PEG 6000, $0.2 \mathrm{M} \mathrm{NaCl}, 30 \%$ formamida) y se hibridaron a $42^{\circ} \mathrm{C}$ durante una noche con el tampón de hibridación conteniendo la sonda marcada y desnaturalizada. Tras la hibridación, las membranas se lavaron secuencialmente durante $15 \mathrm{~min}$ en SSC $3 \mathrm{X}, 0.5 \%$ SDS a $42^{\circ} \mathrm{C}$ y a $55^{\circ} \mathrm{C}$, y en SSC $1 \mathrm{X}, 0.1 \%$ SDS a $42^{\circ} \mathrm{C}$ y a $55^{\circ} \mathrm{C}$. A continuación se lavaron 
durante $5-10 \mathrm{~min}$ en SSC $1 \mathrm{X}, 0.1 \%$ SDS a $60^{\circ} \mathrm{C}$ y a $65^{\circ} \mathrm{C}$, respectivamente. Las membranas se expusieron a auto-radiografía con películas Hyperfilm (Amersham Biosciences) a $-80^{\circ} \mathrm{C}$ en presencia de pantallas intensificadoras. Las películas se revelaron en un procesador automático M35 X-Omat (Kodak).

\subsection{RT-PCR semicuantitativa}

La síntesis de la primera cadena de cDNA se realizó utilizando el sistema First Strand cDNA synthesis kit (Amersham Biosciences). El RNA total tratado con DNasa (3 $\mu \mathrm{g})$ (ver apartado 2.1.2) se llevó a $8 \mu \mathrm{l}$ con agua tratada con DEPC, y se incubó a $65^{\circ} \mathrm{C}$ durante $10 \mathrm{~min}$. Este RNA desnaturalizado se transfirió a otro tubo con $5 \mu \mathrm{l}$ de la solución que contiene la transcriptasa reversa, $1 \mu \mathrm{l}$ de DTT y $1 \mu \mathrm{l}$ de oligonucleótido Not I-d(T) $)_{18}$ como cebador. La mezcla se incubó a $37^{\circ} \mathrm{C}$ durante $1 \mathrm{~h}$. Alícuotas $(1 \mu \mathrm{l})$ del heterodúplex RNA-DNA resultante se emplearon como molde en las reacciones posteriores de PCR, en presencia de $2.6 \mathrm{U}$ de polimerasa Expand High Fidelity (Roche Applied Sciences), $200 \mu \mathrm{M}$ dNTPs y $0.6 \mu \mathrm{M}$ de cada cebador específico (Tabla 4), en un volumen final de $50 \mu \mathrm{l}$. El número de ciclos en el que se produce la amplificación exponencial se determinó, para cada gen de cítricos, realizando las reacciones de PCR a 20, 23, 26 y 29 ciclos (Tabla 4).

\begin{tabular}{|c|c|c|c|}
\hline $\begin{array}{l}\text { Unigen de } \\
\text { cítricos }\end{array}$ & $\begin{array}{c}\text { Secuencia de } \\
\text { los cebadores específicos }\end{array}$ & $\begin{array}{l}\mathrm{N}^{\circ} \text { ciclos } \\
\text { PCR }\end{array}$ & $\begin{array}{c}\text { Tamaño } \\
\text { esperado }(\mathrm{pb})\end{array}$ \\
\hline aCL8Contig9 & $\begin{array}{l}\text { S 5'-GGAGGACAGGACAAGATTGGA } \\
\text { R 5'-ACATTCATGGCCACATCTCAA }\end{array}$ & 21 & 400 \\
\hline aCL172Contig2 & $\begin{array}{l}\text { S 5'-GGCAGCCGACAAATCAGTAG } \\
\text { R 5'-TTGGGAACCCAGACAATGTG }\end{array}$ & 21 & 250 \\
\hline aCL48Contig1 & $\begin{array}{l}\text { S 5'-CATGATTGTGCAAGAGCAAGAG } \\
\text { R 5'-CTAAAGCGTGTATTGGCAGCTT }\end{array}$ & 21 & 250 \\
\hline aCL3307Contig1 & $\begin{array}{l}\text { S 5'-CGACCGGCTACTTTTCTTGA } \\
\text { R 5'-TGGGCACATCATCCACATAG }\end{array}$ & 20 & 450 \\
\hline aCL43Contig3 & $\begin{array}{l}\text { S 5'-CGGCCTCAAGTCTTCTTCTG } \\
\text { R 5'-CTGCACTTGACGCTTGTTGT }\end{array}$ & 20 & 450 \\
\hline aCL960Contig1 & $\begin{array}{l}\text { S 5'-ATTGTTGCTGCTGCTGCTTT } \\
\text { R 5'-GCAACCGACCTTCCTTTTTC }\end{array}$ & 26 & 400 \\
\hline aCL563Contig1 & $\begin{array}{l}\text { S 5'-CAGCCATCTCTCATCGGAAT } \\
\text { R 5'-CCTGTGGACAATGGATGGAC }\end{array}$ & 21 & 350 \\
\hline
\end{tabular}

Los parámetos de las reacciones de PCR fueron de $94^{\circ} \mathrm{C}$ durante $3 \mathrm{~min}$, seguido de un número variable de ciclos (dependiendo de cada gen, Tabla 4) de $94^{\circ} \mathrm{C}$ durante $30,60^{\circ} \mathrm{C}$ durante $45 \mathrm{~s}$ y $72^{\circ} \mathrm{C}$ durante $45 \mathrm{~s} \mathrm{y}$, finalmente, $72^{\circ} \mathrm{C}$ durante $10 \mathrm{~min}$. Alícuotas de los productos de PCR $(20 \mu \mathrm{l})$ se separaron por electroforesis en geles de 
agarosa al 1\%, TAE 1X y $0.5 \mu \mathrm{g} / \mathrm{ml}$ BrEt. La cuantificación de los productos de PCR se realizó sobre la imagen del gel utilizando el programa GeneSnap (SynGene). El unigen de cítricos aCL563Contig1 que codifica una actina (CX289161) se utilizó como control interno.

\section{Medidas de fotosíntesis}

La tasa neta de fotosíntesis ( $\mathrm{PN}, \mu \mathrm{mol} \quad \mathrm{CO}_{2} \cdot \mathrm{m}^{-2} \cdot \mathrm{s}^{-1}$ ) se midió en hojas completamente expandidas de la brotación de otoño, seleccionadas al azar, de las plantas transgénicas de citrange Carrizo que sobre-expresan el gen CcGA20ox1 y de las plantas control, utilizando un medidor portátil de fotosíntesis CIRAS-2 (PP Systems). La tasa neta de fotosíntesis se midió a una radiación fotosintética activa (PAR) de 600, 800 y $1000 \mu \mathrm{mol} \cdot \mathrm{m}^{-2} \cdot \mathrm{s}^{-1}$. El flujo de aire a través de la cámara fue de $195 \mathrm{ml} / \mathrm{min}$ y la temperatura del aire se mantuvo entre $25-27^{\circ} \mathrm{C}$ en todas las medidas realizadas. En estas mismas condiciones se midió la conductancia estomática $\left(\mathrm{G}_{\mathrm{s}}, \mathrm{mmol} \cdot \mathrm{m}^{-2} \cdot \mathrm{s}^{-1}\right)$ y la transpiración $\left(\mathrm{E}, \mathrm{mmol} \cdot \mathrm{m}^{-2} \cdot \mathrm{s}^{-1}\right)$. El análisis estadístico de los datos de PN, $G_{s}$ y E se realizó utilizando el paquete estadístico SPSS (Norusis, 1993), mediante el análisis de la varianza (ANOVA) para determinar el efecto del genotipo y las interacciones entre el genotipo y el aporte de PAR. 


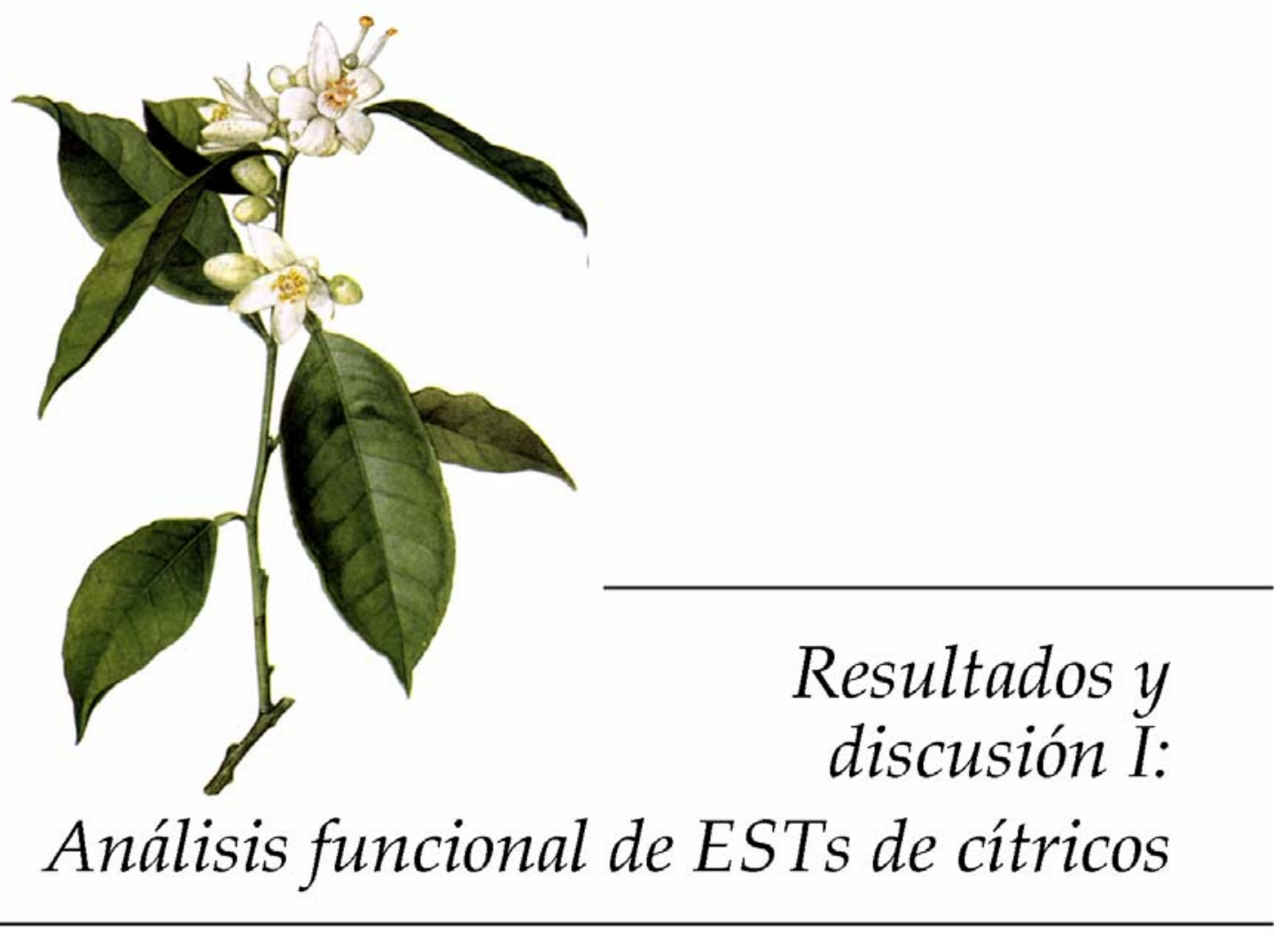





\section{GENES IMPLICADOS EN EL DESARROLLO VEGETATIVO EN CÍTRICOS}

\subsection{Obtención de una genoteca de tejidos vegetativos}

El desarrollo vegetativo determina la forma y el comportamiento fisiológico general de la planta, de modo que tiene una influencia decisiva en la cantidad y calidad de la producción de fruta, así como en las prácticas culturales. Con objeto de obtener información sobre los genes implicados en el desarrollo vegetativo en cítricos se construyó una genoteca de cDNA, denominada Veg1, tal como se ha descrito en Materiales y Métodos, a partir de los siguientes tejidos vegetativos de la variedad mandarina Clemenules (Citrus clementina Hort. Ex Tan.) injertada sobre el patrón mandarino Cleopatra (Citrus reshni Hort. Ex Tan.): brotes jóvenes tratados con $\mathrm{GA}_{3}$, brotes jóvenes tratados con paclobutrazol y hojas y entrenudos procedentes de brotes jóvenes sin tratar. Las titulaciones de las genotecas primaria y amplificada fueron de $2.3 \times 10^{6}$ y $1.0 \times 10^{10} \mathrm{pfu} / \mathrm{ml}$, respectivamente. El análisis por PCR de 1,152 clones procedentes de la genoteca amplificada Veg1 permitió estimar que la longitud media de los fragmentos de cDNA fue de $1,400 \mathrm{pb}$ (Tabla Suplementaria III). En la distribución por tamaño de los insertos (Fig. 10) se observó que la longitud de la mayor parte de los mismos (63\%) superó las 1,000 pb. El rango de tamaños observado, entre 500 y $4,000 \mathrm{pb}$, se corresponde con la distribución esperada para la mayoría de los mRNAs (Sambrook et al, 1989).

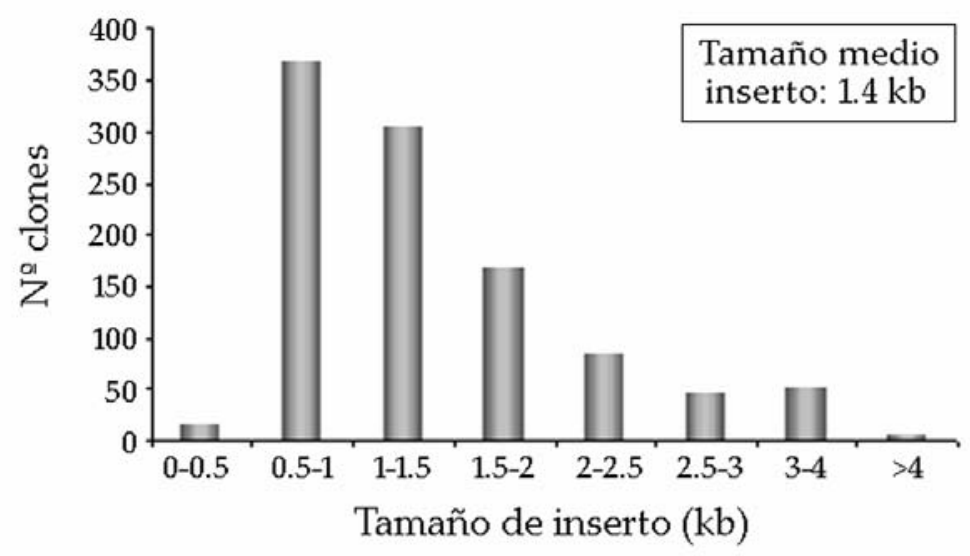

Fig. 10. Distribución por tamaños de los insertos de la genoteca Veg1.

Una genoteca de cDNA constituye una herramienta útil en genómica funcional pues permite identificar y caracterizar genes relevantes de un organismo. En este trabajo se ha construido una genoteca de cDNA a partir de diversos tejidos vegetativos de Citrus clementina. Según la fórmula de Clarke-Carbon, una genoteca de cDNA 
debe contener teóricamente al menos $3.3 \times 10^{5}$ clones independientes para poder aislar un clon derivado de mRNA de baja abundancia con un 99\% de probabilidad (Sambrook et al, 1989). Debido al limitado volumen y a la insuficiente estabilidad de las genotecas primarias es necesario amplificar la genoteca. La capacidad obtenida, tanto de la genoteca primaria como de la amplificada, $2.3 \times 10^{6} \mathrm{pfu} / \mathrm{ml}$ y $1.0 \times 10^{10} \mathrm{pfu} / \mathrm{ml}$, respectivamente, cumple los requerimientos para aislar un clon de cDNA derivado de mRNA de baja abundancia. El tamaño medio de los transcritos de plantas es de 1,500 pb (Alexandrov et al, 2006). Los resultados muestran que la mayor parte de los insertos de la genoteca Veg1 tiene un tamaño superior a 1,000 pb, con un tamaño medio de 1,400 pb. La genoteca Veg1 constituye pues una buena herramienta para posteriores análisis como la secuenciación masiva de ESTs (expressed sequence tags, o secuencias parciales de cDNA aisladas al azar a partir de una población de transcritos), el aislamiento de genes completos y el análisis de perfiles de expresión génica.

\subsection{Colección de ESTs: secuenciación y agrupamiento}

La generación de ESTs es una aproximación eficiente para identificar el conjunto de genes que se expresa en un organismo (por ejemplo, da Silva et al, 2005; Newcomb et al, 2006; Terol et al, 2007). Con la finalidad de identificar genes expresados durante el desarrollo vegetativo en cítricos se generó una colección de ESTs a partir de la genoteca amplificada de cDNA procedente de tejidos vegetativos de Citrus clementina. Un total de 1,824 clones independientes de cDNA se aislaron al azar a partir de la genoteca Veg1 y se secuenciaron desde el extremo 5'. Tras el pre-procesado de las secuencias, 1,689 ESTs de alta-calidad que, adicionalmente, superaron $100 \mathrm{pb}$ de longitud, se utilizaron para posteriores análisis (Tabla 5, Tabla Suplementaria IV). La longitud de dichas ESTs, comprendida entre 101 y 810 bases, con una longitud media de 542 bases, fue relativamente superior a los valores obtenidos en otros proyectos de secuenciación de ESTs como el de Populus con 470 pb (Sterky et al, 2004) o el de manzano con 468 pb (Newcomb et al, 2006). La distribución por tamaños de las ESTs mostró que la mayoría de ellas (82\%) tenían una longitud igual o superior a 400 bases (Tabla Suplementaria IV).

El número combinado de contigs y singletons que resulta de un proceso computacional de agrupamiento o ensamblaje de ESTs constituye una estimación del número de genes únicos de un organismo de modo que a medida que el número de ESTs crece, el número de genes únicos deberá ser redefinido. Los 1,824 clones de la genoteca Veg1 fueron agrupados inicialmente en 703 contigs y 719 singletons cuando 
la colección de ESTs de cítricos del CFGP contaba con 22,635 ESTs (Forment et al, 2005). Dado que la colección de ESTs de cítricos del CFGP ha crecido considerablemente, en la actualidad contiene 85,965 ESTs agrupadas en 27,551 unigenes (11,844 contigs y 15,707 singletons), los resultados de este trabajo han sido redefinidos dado que consideramos que, pese al esfuerzo adicional que ello conlleva, suponen una mejor estimación del número de genes únicos. Así pues, las ESTs procedentes de la genoteca Veg1 se ensamblaron junto con el conjunto total de ESTs obtenidas en el CFGP (85,965 ESTs) de modo que del total de 1,689 ESTs de alta-calidad, 1,262 ESTs quedaron agrupadas en 971 contigs o conjuntos de secuencias formados por dos o más ESTs, mientras que las restantes 427 ESTs se clasificaron como singletons, pues no mostraron similitud con ninguna otra secuencia de la colección (Tabla 5, Tabla Suplementaria IV).

\begin{tabular}{lr}
\hline \multicolumn{2}{l}{ Tabla 5. Resumen de la colección de ESTs de la genoteca Veg1 } \\
\hline Resultados de la secuenciación & \\
Número de clones de cDNA aislados & 1,824 \\
Número de clones de cDNA secuenciados & 1,771 \\
Número de ESTs de alta-calidad & 1,689 \\
Longitud media de las ESTs & 542 bases \\
Resultados del agrupamiento & \\
Número de ESTs ensambladas & \\
Número de contigs & 1,689 \\
Número de singletons & 971 \\
Número de unigenes & 427 \\
Redundancia & 1,398 \\
Unigenes únicos & $17 \%$ \\
Novedad & 439 \\
La redundancia se ha estimado como [1-(Unigenes/ESTs) x 100] \\
y la novedad como [Unigenes únicos/Unigenes) x 100] \\
\hline
\end{tabular}

La generación de una colección de ESTs constituye un método relativamente rápido y potente para la identificación de genes, para la confirmación de las regiones codificantes en secuencias genómicas, para el estudio de relaciones filogenéticas, para la estimación de los niveles de expresión de los genes de los que proceden y para el desarrollo de micromatrices de cDNA (Alba et al, 2004). Sin embargo, una colección de ESTs presenta ciertas limitaciones. Una de ellas es la generación de ESTs redundantes derivadas de los transcritos más comunes, lo que puede reducir la eficiencia de esta aproximación. Las 1,689 ESTs obtenidas de la genoteca Veg1 representaron 1,398 unigenes o posibles transcritos únicos (971 contigs y 427 singletons) de modo que la redundancia de esta genoteca fue del $17 \%$. Adicionalmente, la genoteca Veg1 aportó un total de 439 unigenes únicos a la colección del CFGP (valor obtenido añadiendo al número de singletons el número de 
contigs formados sólo por ESTs de la genoteca Veg1) lo que supone una novedad del $31 \%$. Este valor es una estimación de la capacidad de la genoteca para aportar nuevos genes a la colección. El bajo nivel de redundancia obtenido, junto al porcentaje relativamente elevado de novedad, indican que el potencial de esta genoteca para aislar genes de cítricos no ha sido agotado en este trabajo, de modo que la genoteca Veg1 puede secuenciarse con más profundidad permitiendo la identificación de nuevos genes de Citrus clementina.

\subsection{Anotación funcional de los unigenes}

Muchos de los unigenes pueden ser asignados a una función en base a la similitud de secuencia con proteínas o genes, bien con una función demostrada o bien con posibles funciones basadas asimismo en la similitud de secuencia con otros genes conocidos. La asignación de una posible función a cada uno de los unigenes obtenidos a partir de la genoteca Veg1 se realizó comparando la secuencia consenso de cada unigen, mediante BLAST (Altschul et al, 1997), con las bases de datos de proteínas: TAIR pep y UniRef90 pep. Además se identificaron los motivos funcionales mediante una búsqueda HMMER utilizando la base de datos Pfam (ver Materiales y Métodos). En la Tabla 6 se muestra el número de unigenes con secuencias similares en las diferentes bases de datos según los distintos niveles de significatividad (valores $E$ ) considerados. La comparación con el conjunto completo de proteínas de Arabidopsis (TAIR pep) permitió asignar una posible función (basado en un valor $E<10^{-5}$ ) al $83.1 \%$ (1162) de los unigenes (Tabla 6, Anejo I). Los resultados de las búsquedas por similitud de secuencia obtenidos en cada base de datos consultada, se recogen, para cada unigen de la genoteca Veg1, en la Tabla Suplementaria V.

\begin{tabular}{|c|c|c|c|c|c|}
\hline \multirow{2}{*}{ Base de Datos } & \multicolumn{4}{|c|}{$\mathrm{N}^{\circ}$ total de unigenes con secuencia similar } & \multirow{2}{*}{$\begin{array}{c}\text { Sin secuencia } \\
\text { similar }\end{array}$} \\
\hline & $\mathrm{E}<10^{-5}$ & $\mathrm{E}<10^{-20}$ & $\mathrm{E}<10^{-50}$ & $\mathrm{E}<10^{-100}$ & \\
\hline TAIR pep & 1,162 & 1,044 & 722 & 321 & 236 \\
\hline UniRef90 pep & 1,184 & 1,061 & 743 & 339 & 214 \\
\hline Pfam & 619 & 510 & 281 & 281 & 779 \\
\hline
\end{tabular}

El análisis de los resultados obtenidos en la base de datos UniRef90pep nos permitió estimar que de los 1,398 unigenes de la genoteca Veg1, un $72.5 \%$ $\left(1,013\right.$ unigenes) presenta una similitud de secuencia significativa (valor $\left.E<10^{-5}\right)$ con proteínas cuya función es conocida, un 12.2\% (171 unigenes) con proteínas de función 
desconocida y un $15.3 \%$ (214 unigenes) no tiene similitud de secuencia con ninguna proteína de la base de datos utilizada (Fig. 11, Tabla Suplementaria V).

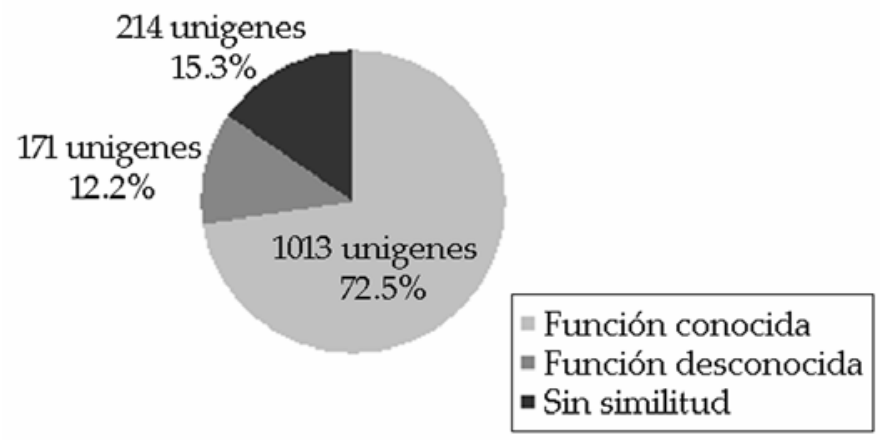

Fig. 11. Clasificación funcional general de los unigenes procedentes de la genoteca de cDNA de tejidos vegetativos según los resultados obtenidos en la base de datos UniRef90 pep.

Este último grupo probablemente incluye genes específicos de cítricos, aunque también puede incluir secuencias no codificantes (UTRs), secuencias contaminantes de DNA o artefactos. La proporción de genes específicos de cítricos se estimó comparando las secuencias de estos 214 unigenes, mediante BLASTX, con la base de datos PlantTA (Childs et al, 2007; http://plantta.tigr.org), excluyendo de ella los datos procedentes de los géneros Citrus y Poncirus. Los resultados de este análisis (Tabla Suplementaria V) indican que, de los 1,398 unigenes obtenidos de Veg1, 172 (12.3\%) no muestran similitud significativa con ninguna secuencia de plantas, por lo que podrían ser considerados específicos de cítricos.

\subsection{Ontologías génicas enriquecidas en Veg1}

El principal objetivo de un experimento de escala genómica es obtener una interpretación funcional de los datos de modo que sea posible relacionar dicha información con la hipótesis que originó el experimento. La anotación funcional de los genes permite estructurarlos según su función. En este trabajo se utilizaron dos fuentes de información funcional para la anotación de los unigenes de cítricos procedentes de la genoteca Veg1: la Ontología Génica (GO; Ashburner et al, 2000) organizada en tres categorías generales ('proceso biológico', 'función molecular' y 'componente celular') y el Catálogo Funcional (FunCat; Ruepp et al, 2004) del MIPS (Munich Information Centre for Protein Sequences; http://mips.gsf.de). En primer lugar, para cada unigen de cítricos de la genoteca Veg1 se obtuvo el código AGI (Arabidopsis Genome Initiative, 2000) del gen de Arabidopsis más similar (Anejo I). Posteriormente, a cada uno de estos genes (1,162 unigenes) se le asignó una 
categoría funcional MIPS utilizando la herramienta FunCat y las ontologías génicas mediante el programa FatiGo (Al-Shahrour et al, 2004). De este modo, un total de 981 unigenes fueron adscritos a una o más categorías funcionales según FunCat (Tabla Suplementaria VI). En el caso de la anotación funcional según GO, 598 unigenes se anotaron con una o más ontologías en la componente 'proceso biológico' (Tabla Suplementaria VI), 644 unigenes en 'función molecular' y 718 unigenes en 'componente celular'. En la Tabla 7 se muestra un resumen de la anotación funcional de los unigenes de Veg1 siguiendo el Catálogo Funcional del MIPS. La categoría que presentó un mayor número de unigenes fue la de 'localización subcelular' (23\%), seguida de 'proteínas con función de unión' (14.77\%), 'metabolismo' (10.38\%), 'procesado de proteínas' (7.61\%), 'transporte celular' (5.60\%) e 'interacción con el ambiente' $(4.70 \%)$.

\begin{tabular}{lrr}
\hline Tabla 7. Clasificación funcional según FunCat de los unigenes de Veg1 & \\
\hline \multicolumn{1}{c}{ CATEGORÍA FUNCIONAL } & \multicolumn{2}{c}{ Citrus } \\
\cline { 2 - 3 } & \multicolumn{1}{c}{$\mathrm{N}^{\circ}$} & $\%$ \\
\hline 01 Metabolismo & 232 & $10.38 \%$ \\
02 Energía & 48 & $2.15 \%$ \\
04 Proteínas de Reserva & 2 & $0.09 \%$ \\
10 Ciclo Celular y Procesamiento del ADN & 48 & $2.15 \%$ \\
11 Transcripción & 76 & $3.40 \%$ \\
12 Síntesis de Proteínas & 48 & $2.15 \%$ \\
14 Procesado de Proteínas (plegamiento, modificación, destino) & 170 & $7.61 \%$ \\
16 Proteínas con Función de Unión o Necesidad de Cofactores & 330 & $14.77 \%$ \\
18 Regulación del Metabolismo & 30 & $1.34 \%$ \\
20 Transporte Celular & 125 & $5.60 \%$ \\
30 Comunicación Celular - Transducción de Señal & 53 & $2.37 \%$ \\
32 Defensa & 98 & $4.39 \%$ \\
34 Interacción con el Ambiente & 105 & $4.70 \%$ \\
36 Interacción Sistémica con el Ambiente & 39 & $1.75 \%$ \\
38 Elementos transponibles, Proteínas Virales y Plasmídicas & 1 & $0.04 \%$ \\
40 Procesado Celular & 21 & $0.94 \%$ \\
41 Desarrollo (Sistémico) & 37 & $1.66 \%$ \\
42 Biogénesis de Componentes Celulares & 57 & $2.55 \%$ \\
43 Diferenciación de Tipos Celulares & 7 & $0.31 \%$ \\
45 Diferenciación de Tejidos & 3 & $0.13 \%$ \\
47 Diferenciación de Órganos & 7 & $0.31 \%$ \\
70 Localización Subcelular & 514 & $23.01 \%$ \\
73 Localización Celular & 1 & $0.04 \%$ \\
75 Localización Tisular & 1 & $0.04 \%$ \\
99 Proteínas sin Clasificación & 181 & $8.10 \%$ \\
\hline
\end{tabular}

El análisis de la información funcional disponible para los genes analizados constituye un paso necesario, pero no suficiente, para la interpretación funcional de un experimento a escala genómica. De hecho, un error conceptual típico consiste en asignar importancia a las funciones más abundantes (Dopazo y Al-Shahrour, 2007). Es decir, los grupos funcionales más abundantes en el conjunto de los unigenes procedentes de la genoteca Veg1 pueden ser simplemente aquéllos más abundantes 
de modo general en la planta. Con objeto de caracterizar la colección de unigenes obtenida en relación al desarrollo vegetativo, se realizó un análisis de enriquecimiento funcional mediante el cual se comparó el conjunto de unigenes obtenidos de la genoteca Veg1 con el genoma completo de Arabidopsis. La cuestión subyacente a este análisis es: ¿existe alguna función representada por una proporción de genes significativamente mayor en el subconjunto de unigenes procedentes de tejidos vegetativos de lo que cabría esperar en el genoma completo de Arabidopsis?. La herramienta FatiGO (Al-Shahrour et al, 2004) permite encontrar términos GO significativamente sobre-representados en un conjunto de genes respecto a un grupo de referencia. Los resultados obtenidos para la ontología 'proceso biológico' se recogen en la Figura 12 y en la Tabla Suplementaria VII.

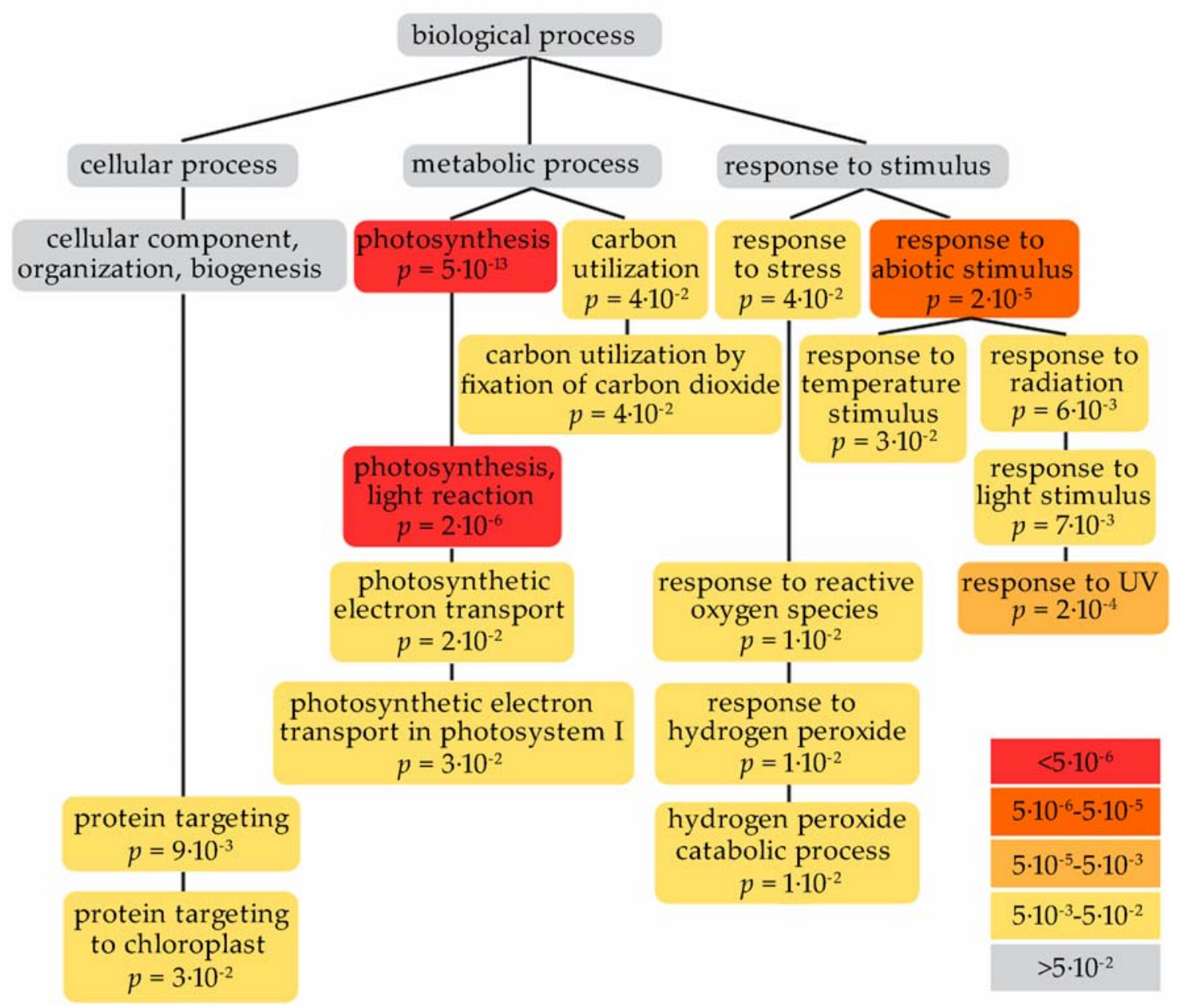

Fig. 12. Ontologías génicas de la componente 'proceso biológico' sobre-representadas en el conjunto de unigenes de la genoteca Veg1. La escala de color muestra el nivel de significatividad, considerando ontologías enriquecidas aquéllas cuyo valor $p$ corregido es inferior a 0.05 . 
El conjunto de unigenes de cítricos generados a partir de la genoteca Veg1 mostró una sobre-representación significativa (valor $p$ corregido $<0.05$ ) de aquellos unigenes pertenecientes a las ontologías génicas no redundantes de 'transporte fotosintético de electrones en el fotosistema l', 'utilización de carbono por fijación de $\mathrm{CO}_{2}$ ', 'proteínas dirigidas al cloroplasto', 'catabolismo del peróxido de hidrógeno', 'respuesta a temperatura' y 'respuesta a ultravioleta' (Fig. 12, Tabla Suplementaria VII). Las dos primeras ontologías están relacionadas con una de las funciones fisiológicas clave del desarrollo vegetativo, la fotosíntesis, de modo que se analizaron en detalle y los resultados obtenidos se presentan en los siguientes apartados.

Durante la fotosíntesis se producen y se destruyen distintas especies reactivas del oxígeno de un modo controlado que contribuye a la regulación del transporte de electrones (Noctor y Foyer, 1998). La sobre-representación de unigenes relacionados con el 'catabolismo del peróxido de hidrógeno' en la genoteca Veg1 como catalasa, que convierte el peróxido de hidrógeno en oxígeno y agua, y monodehidroascorbato reductasa, que regenera ascorbato, indica la importancia de los sistemas de defensa frente a las especies de oxígeno reactivo en los tejidos fotosintéticos. Las ontologías génicas sobre-representadas de 'respuesta a temperatura' y 'respuesta a UV' están relacionadas con dos de los estímulos ambientales más relevantes para el desarrollo vegetativo, la temperatura y la luz (Fig. 12, Tabla Suplementaria VII). La genoteca Veg1 se construyó a partir de tejidos vegetativos procedentes de la brotación de otoño de árboles adultos de campo (apartado 1.1 de Materiales y Métodos). Es posible que la sobre-representación de dichas ontologías génicas esté relacionada con las condiciones climáticas. Los organismos fotosintéticos se aclimatan a las condiciones de luz del ambiente previniendo los posibles daños del exceso de irradiación lo que resulta coherente con la sobre-representación de la ontología de 'respuesta a UV'.

\subsubsection{Fotosíntesis}

La fotosíntesis oxigénica es el principal proceso por el que la luz solar se convierte en energía química y está catalizado por cuatro complejos multi-proteicos de membrana (Fig. 13): fotosistema I (PSI), fotosistema II (PSII), citocromo b/f y ATP sintasa. La fotosíntesis oxigénica requiere la actividad del PSII para la ruptura del agua. Los electrones generados en esta oxidación son transferidos a plastoquinona $(P Q)$, unida al PSII, que se reduce a plastoquinol $\left(\mathrm{PQH}_{2}\right)$ en la membrana tilacoidal. El complejo citocromo b/f oxida el plastoquinol y reduce la plastocianina (PC) en el lumen tilacoidal. EI PSI oxida la PC y reduce la ferredoxina (Fd) en el estroma. La reducción 
del $\mathrm{NADP}^{+}$por la ferredoxina está catalizada por la enzima ferredoxina-NADP ${ }^{+}$ reductasa (FNR). Durante este transporte de electrones del agua al $\mathrm{NADP}^{+}$, se produce la transferencia de protones del estroma al lumen en varios puntos: 1) la oxidación del agua libera $\mathrm{H}^{+}$en el lumen, 2) la reducción de $\mathrm{PQ}$ por el complejo citocromo b/f está acompañada por una translocación de protones del estroma al lumen. Este gradiente de protones al lumen es utilizado por ATP sintasa para generar ATP (Scheller et al, 2005).

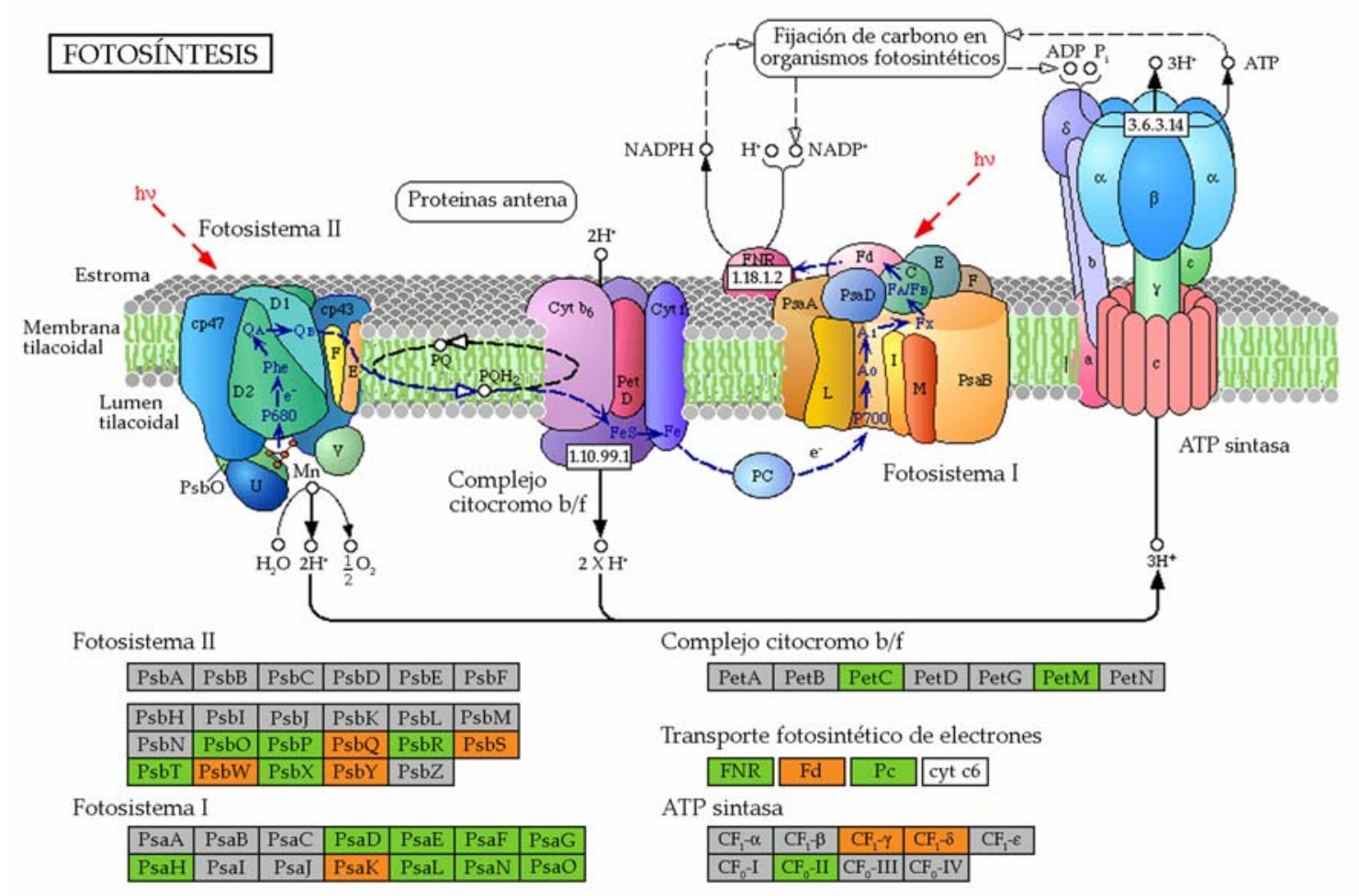

Fig. 13. Esquema del transporte de electrones en las membranas tilacoidales mostrando los cuatro complejos de membrana: fotosistema I y II, complejo citocromo b/f y ATP sintasa. En la parte inferior se indican las subunidades que forman cada uno de los complejos en plantas superiores; en gris las subunidades codificadas por genes cloroplásticos, en color las codificadas por genes nucleares, verde cuando se aislaron unigenes a partir de la genoteca Veg1 y naranja cuando se identificaron unigenes sólo de otras genotecas del CFGP.

Los cuatro componentes de la cadena de transporte electrónico están constituidos por múltiples subunidades que, en plantas superiores, están codificadas por genes cloroplásticos y por genes nucleares (Fig. 13). A partir del conjunto de ESTs del CFGP se obtuvieron los unigenes que codifican cada una de estas subunidades en cítricos. Además, se identificaron los unigenes de cítricos que codifican ferredoxina$\mathrm{NADP}^{+}$reductasa (FNR), ferredoxina $(\mathrm{Fd})$ y plastocianina $(\mathrm{PC})$, proteínas implicadas en el transporte de electrones (Tabla 8, Tabla Suplementaria VIII). En la genoteca Veg1, preparada a partir de tejidos vegetativos (hojas y entrenudos procedentes de brotes vegetativos en desarrollo) se identificaron 45 ESTs (2.7\%) que corresponden a 
la mayoría de los genes que codifican proteínas implicadas en la cadena de transporte electrónico (Tabla 8).

\begin{tabular}{|c|c|c|c|c|}
\hline Proteína & $\begin{array}{c}N^{\circ} \text { ESTs resto } \\
\text { CFGP (\%) }\end{array}$ & $\begin{array}{l}\text { № ESTs } \\
\text { Veg1 (\%o) }\end{array}$ & $\begin{array}{l}\text { Enriquecimiento } \\
\text { en Veg1 }\end{array}$ & Significatividad \\
\hline \multicolumn{5}{|c|}{ Fotosistema II } \\
\hline PsbO & $35(0.42)$ & $6(3.55)$ & 9 & $>0.999$ \\
\hline PsbP & $22(0.20)$ & $5(2.96)$ & 15 & $>0.999$ \\
\hline PsbQ & $15(0.18)$ & - & & \\
\hline PsbR & $17(0.20)$ & $3(1.78)$ & 9 & $>0.99$ \\
\hline PsbS & $13(0.15)$ & - & & \\
\hline PsbT & $10(0.12)$ & $2(1.18)$ & 10 & $>0.95$ \\
\hline PsbW & $20(0.24)$ & - & & \\
\hline PsbX & $9(0.11)$ & $5(2.96)$ & 28 & $>0.999$ \\
\hline PsbY & $12(0.14)$ & - & & \\
\hline \multicolumn{5}{|c|}{ Fotosistema I } \\
\hline PsaD & $13(0.15)$ & $2(1.18)$ & 8 & $>0.95$ \\
\hline PsaE & $8(0.09)$ & $1(0.59)$ & & \\
\hline PsaF & $24(0.28)$ & $2(1.18)$ & 4 & $>0.95$ \\
\hline PsaG & $7(0.08)$ & $4(2.37)$ & 29 & $>0.999$ \\
\hline PsaH & $3(0.04)$ & $6(3.55)$ & 100 & $>0.999$ \\
\hline PsaK & $7(0.08)$ & - & & \\
\hline PsaL & $7(0.08)$ & $1(0.59)$ & & \\
\hline PsaN & $6(0.07)$ & $2(1.18)$ & 12 & $>0.99$ \\
\hline PsaO & $6(0.07)$ & $1(0.59)$ & & \\
\hline \multicolumn{5}{|c|}{ Complejo citocromo b/f } \\
\hline PetC & $12(0.14)$ & $1(0.59)$ & & \\
\hline PetM & $68(0.81)$ & - & & \\
\hline \multicolumn{5}{|c|}{ ATP sintasa } \\
\hline AtpA & $1(0.01)$ & - & & \\
\hline AtpD & $11(0.13)$ & - & & \\
\hline AtpG & $3(0.04)$ & $1(0.59)$ & 17 & $>0.95$ \\
\hline \multicolumn{5}{|c|}{ Transporte fotosintético de electrones } \\
\hline PetH (FNR) & $8(0.09)$ & $1(0.59)$ & & \\
\hline PetF $(\mathrm{Fd})$ & $32(0.38)$ & - & & \\
\hline PetE (Pc) & $16(0.19)$ & $2(1.18)$ & 6 & $>0.95$ \\
\hline
\end{tabular}

La colección de ESTs del CFGP se ha generado a partir de 52 genotecas de cDNA que cubren un amplio rango de tejidos, estadios de desarrollo y condiciones de estrés biótico y abiótico. Sin embargo, los datos de expresión obtenidos como la frecuencia de ESTs asignada a los genes que codifican proteínas de los complejos estudiados indican una expresión diferencial en los tejidos vegetativos (Tabla 8), lo que es consistente con su importancia en el transporte fotosintético de electrones.

\subsubsection{Fotosíntesis: proteínas de la antena}

Las proteínas Lhc (light-harvesting chlorophyll a/b binding) participan en la maximización y regulación de la captación de luz en los fotosistemas. Seis de las 
proteínas Lhc (Lhcb1 a 6) están asociadas con el fotosistema II y las seis restantes (Lhca1 a 6) forman parte del fotosistema I (Fig. 14). Recientemente, se ha sugerido la existencia de un gen que codifica una nueva proteína Lhc (Lhcb7) (Klimmek et al, 2006).

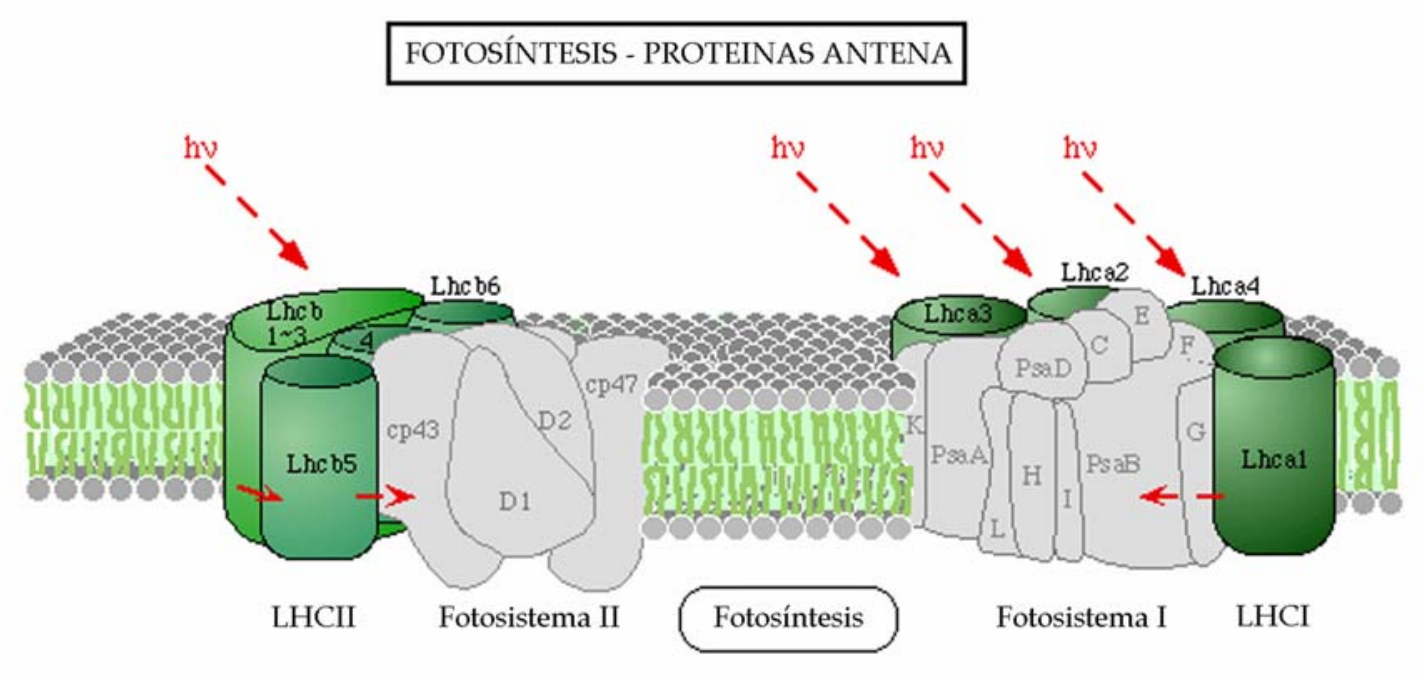

Complejo proteico de clorofilas de captación de luz (LHC)

\begin{tabular}{|l|l|l|l|l|l|}
\hline Lhcb1 & Lhcb2 & Lhcb3 & Lhcb4 & Lhcb5 & Lhcb6 \\
\hline
\end{tabular}

\begin{tabular}{|l|l|l|l|l|l|}
\hline Lhcal & Lhca2 & Lhca3 & Lhca4 & Lhca5 & Lhca6 \\
\hline
\end{tabular}

Fig. 14. Proteínas Lhc en cítricos. En cajas verdes se indican los tipos de proteínas Lhc para los que se aislaron unigenes a partir de la genoteca Veg1, y en cajas naranjas los tipos de proteínas Lhc para los que se identificaron unigenes sólo de otras genotecas del CFGP.

En la colección de ESTs generada a partir de la genoteca Veg1 se identificaron unigenes correspondientes a Lhcb1, -2, -4, -5 y -6 y Lhca2, -3 y -4 (Fig. 14). Adicionalmente, utilizando las ESTs de cítricos depositadas en la base de datos del CFGP (http://bioinfo.ibmcp.upv.es/genomics/cfgpDB/) se extrajeron todas las secuencias significativamente similares a los genes Lhc de Arabidopsis, de modo que en el conjunto de ESTs de cítricos del CFGP se encontraron representados los 12 tipos diferentes de proteínas Lhc: Lhcb1 a 6 y Lhca 1 a 6 (Fig. 14, Tabla Suplementaria IX). En cuanto a Lhcb7, en la colección de ESTs del CFGP, se identificaron tres ESTs de cítricos que corresponden a este gen. El alineamiento de la secuencia de aminoácidos deducida de $L h c b 7$ de Arabidopsis, arroz, chopo y Citrus (Fig. 15) mostró que la secuencia de cítricos tiene conservados los motivos Lhc conocidos, incluyendo el motivo específico Lhcb7 y el motivo de trimerización presente en Lchb1, Lchb2 y Lhcb3 (Klimmek et al, 2006). La existencia de Lhcb7 no ha sido demostrada a nivel de proteína, pero el hecho de que el gen $L c h b 7$ se transcribe y, por 
tanto, está representado por ESTs de diferentes especies, entre ellas, cítricos, y que se encuentra conservado (Fig. 15) indica que codifica una proteína funcional.

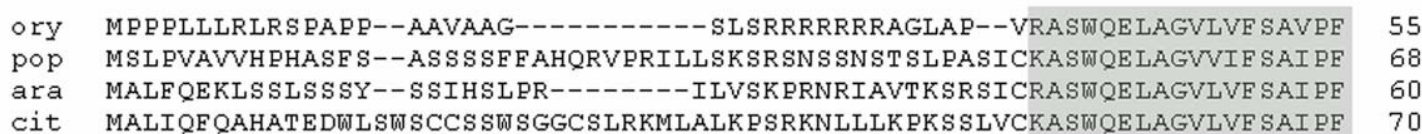

motivo-lhcb7

OYY TAVKALANSPLGARLCRRLDDRKAAAAAEADALRSAARQARTASSWYGDERPRWLGPVPYEYPAHLTGEY 125

pop TAVKAIANS PLGESLQRRLEERKKLAVQQSSKEKALAQKARKESEWYGEERPRWLGPISYQYPTYLSGEL 138

ara TAVKAIANSSIGVSLRRRLEEKKKEAVENSSREKSKAQEARNDSKWYGKERPRWFGPIPYDYPPYLTGEL 130

cit TAVKAIANSPLGELLQNRMLETKKA.ALQDSSKEKALARQARNESLWYGEERPRWLGPI PYDYPSYLTGEL 140 motivo de trimerización

OrY PGDY GFDIAGLGRDPVAF ANYENEEILHCRWAMLAALGVVVELLDLFGVVHFVE FVWWKVG AKLQGDT 195 pop PGDYGEDVAGLAEDPVAFQRYENEEILHARWAMLAALGALI PEVLDLSGAFHF IE FVWWRVG SKLKGDT 208 ara PGDYGEDIAGLGKDRLTEDKYENEEILHARWAMLAALGALI PEVEDLTGTEHF AE EVWWRGYSKLQGET 200 cit PGDYGE DVAGLSKD PMAFQKYENEEILHARWAMLGALGALVPEVLDMVGAFHLVE FVWWRGYSKLQGET 210 car $\quad \mathrm{B} \quad \mathrm{a} 4$ a5 a1 car

ory LDYLGI PGERIAGGQGVIVIAICQALLMVGEEYARCGIEALEPLGLYLPGDINYPGGALFDPLGLSKDP 265

pop LDYLGI PGLHE AGGQGVLVIAFCQA.ILMVGEEYARYGIEALE PLGIYLPGDINYPGGILFDPLNLSKDP 278

ara LEYLGI PGLHVAGSQGVIVIAICQVVLMVGEEYARYCGIEALE PLGIYLPGDINYPGGTLEDPLNLSEDP 270

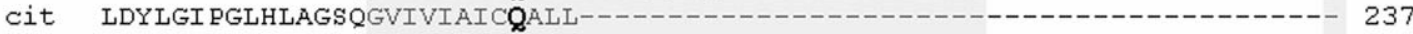

C b6 b5 b5

OrY VAFEDLKVKEIKNGRLAMVAWLGEYIQAAVTGKGPIQNLVEHLSDPLHNNILSSEV-- 321

pop VSEEELKVKEIKNGRLAMVAWLGEYIQAALTGKGPVENLVEHISDPLHNNLESTLKLV 336

ara VAFEDLKVKEIKNGRLAMVAWLGFYAQAAFTGKGPVQNLVDHVSDPLHNNLIAMLQT- 327
A
a1 a2 a4
a3
D b3

Fig. 15. Alineamiento de las secuencias deducidas de aminoácidos de Lchb7 de Arabidopsis (ara), chopo (pop), arroz (ory) y Citrus (cit) en las que se indican las hélices transmembrana (A-D), los sitios de unión de carotenoides (car), ligandos de clorofila (letras en negrita), el motivo específico Lhcb7 y el motivo de trimerización (de acuerdo con Klimmek et al, 2006).

Un total de 390 ESTs de cítricos correspondieron a genes que codifican los 12 tipos diferentes de proteínas Lhc, siendo Lhcb1 la más representada (136 ESTs). Los datos de expresión calculados según la frecuencia de ESTs asignada a los genes que codifican las 13 proteínas Lhc (Tabla 9) permitieron distinguir dos grupos. El primero contiene los genes que codifican proteínas Lhc abundantes: Lhca1 a 4 y Lhcb1 a 6 (excepto Lhcb3 para la que sólo se obtuvieron 4 ESTs). Una característica interesante de este grupo es que la mayoría de sus miembros (todos salvo Lhcb3 y Lhca1) aparecieron significativamente sobre-representados en la genoteca generada a partir de brotes vegetativos en desarrollo (Tabla 9; Tabla Suplementaria IX). El segundo grupo incluye los genes que codifican proteínas Lhc poco abundantes: Lhca5 (1 EST), Lhca6 (1 EST) y Lhcb7 (3 ESTs). Una característica común de estos genes fue su ausencia de expresión en brotes jóvenes (Tabla 9). Este patrón de expresión coincide 
con el descrito en chopo (Klimmek et al, 2006) y parece indicar una regulación distinta de los dos grupos de genes Lhc.

\begin{tabular}{|c|c|c|c|c|}
\hline Proteína & $\begin{array}{c}\mathrm{N}^{\circ} \text { ESTs resto } \\
\text { CFGP (\%o) }\end{array}$ & $\begin{array}{l}N^{\circ} \text { ESTs } \\
\text { Veg1 (\%o) }\end{array}$ & $\begin{array}{c}\text { Enriquecimiento } \\
\text { en Veg1 }\end{array}$ & Significatividad \\
\hline Lhcb1 & $123(1.46)$ & $13(7.70)$ & 5 & $>0.999$ \\
\hline Lhcb2 & $49(0.58)$ & $3(1.78)$ & 3 & $>0.95$ \\
\hline Lhcb3 & $4(0.05)$ & - & & \\
\hline Lhcb4 & $49(0.58)$ & $1(0.59)$ & & \\
\hline Lhcb5 & $39(0.46)$ & $5(2.96)$ & 6 & $>0.999$ \\
\hline Lhcb6 & $12(0.14)$ & $2(1.18)$ & 8 & $>0.99$ \\
\hline Lhcb7 & $3(0.04)$ & - & & \\
\hline Lhca1 & $17(0.20)$ & - & & \\
\hline Lhca2 & $26(0.31)$ & $3(1.78)$ & 6 & $>0.99$ \\
\hline Lhca3 & $26(0.31)$ & $3(1.78)$ & 6 & $>0.99$ \\
\hline Lhca4 & $6(0.07)$ & $4(2.37)$ & 33 & $>0.999$ \\
\hline Lhca5 & $1(0.01)$ & - & & \\
\hline Lhca6 & $1(0.01)$ & - & & \\
\hline
\end{tabular}

Los resultados obtenidos muestran que los complejos de captación de luz (antena) de Citrus contienen los mismos tipos de proteínas que los de Arabidopsis y Populus. Además, los datos de expresión de los genes Lhc en Citrus son similares a los obtenidos en estas especies, mostrando que los genes Lhca5, Lhca6 y Lhcb7 presentan un patrón de expresión diferente al de los genes que codifican las proteínas Lhc abundantes. Es de interés señalar que las 5 ESTs de cítricos que corresponden a los genes Lhca5, Lhca6 y Lhcb7 proceden de genotecas preparadas a partir de hojas procedentes de plantas sometidas a diferentes condiciones de estrés: salino, hídrico, deficiencia férrica e infección por el virus de la tristeza de los cítricos. Aunque estos datos de expresión no permiten obtener una conclusión sobre la función específica de las proteínas codificadas, sugieren una posible función de las mismas en condiciones de estrés.

\subsubsection{Fijación de carbono}

Los cítricos pertenecen al grupo de plantas $C_{3}$ de modo que la fijación fotosintética de carbono se produce a través del ciclo de Calvin (Spiegel-Roy y Goldschmidt, 1996). A partir del conjunto de ESTs del CFGP se obtuvieron los unigenes que codifican cada una de las enzimas del ciclo de Calvin en cítricos. Un total de 529 ESTs de cítricos correspondieron a genes que codifican enzimas del ciclo de Calvin, siendo fructosa-bifosfato aldolasa la más representada (157 ESTs) (Tabla 10). En la genoteca Veg1 se identificaron 28 ESTs (1.6\%) relacionadas con el ciclo de 
Calvin. Sin embargo, RuBisCO (18 ESTs) y gliceraldehído-3-P deshidroganasa (5 ESTs) fueron las más abundantes en este caso (Tabla 10).

\begin{tabular}{|c|c|c|c|c|c|}
\hline Enzima & EC & $\begin{array}{l}N^{\circ} \text { Total } \\
\text { ESTs }(\% \circ)\end{array}$ & $\begin{array}{l}\mathrm{N}^{\circ} \text { ESTs } \\
\text { Veg1 (\%o) }\end{array}$ & $\begin{array}{c}\text { Enriquecimiento } \\
\text { en Veg1 }\end{array}$ & Significatividad \\
\hline RuBisCO & 4.1.1.39 & $69(0.80)$ & $18(10.66)$ & 13 & $>0.999$ \\
\hline Fosfoglicerato kinasa & 2.7.2.3 & $50(0.58)$ & $1(0.59)$ & 1 & \\
\hline Gliceraldehido-3-P deshidrogenasa & 1.2.1.13 & $32(0.37)$ & $5(2.96)$ & 8 & $>0.999$ \\
\hline Triosa fosfato isomerasa & 5.3.1.1 & $69(0.80)$ & - & & \\
\hline Fructosa-bifosfato aldolasa & 4.1.2.13 & $156(1.81)$ & $1(0.59)$ & & \\
\hline Fructosa-1,6-bifosfatasa & 3.1.3.11 & $16(0.19)$ & $1(0.59)$ & 3 & \\
\hline Transquetolasa & 2.2.1.1 & $25(0.29)$ & - & & \\
\hline Sedoheptulosa-1,7-bifosfatasa & 3.1.3.37 & $2(0.02)$ & - & & \\
\hline Ribosa 5-fosfato isomerasa & 5.3 .1 .6 & $50(0.58)$ & $1(0.59)$ & 1 & \\
\hline Ribulosa-fosfato 3-epimerasa & 5.1.3.1 & $11(0.13)$ & - & & \\
\hline Fosforibuloquinasa & 2.7.1.19 & $21(0.24)$ & $1(0.59)$ & 2 & \\
\hline
\end{tabular}

La sobre-representación de ESTs (13 veces) correspondientes con RuBisCO observada en la genoteca Veg1 refleja el papel crucial que desempeña esta enzima en la bioquímica de los tejidos vegetativos.

\section{GENES IMPLICADOS EN EL METABOLISMO DE ISOPRENOIDES $Y$ FLAVONOIDES EN CÍTRICOS}

Los cítricos constituyen una fuente importante de metabolitos derivados de isoprenoides, como carotenoides, limonoides y mono- y sesquiterpenos. Por otro lado, los cítricos acumulan grandes cantidades de flavonoides, tanto en los frutos como en las hojas que, además de ser responsables del aroma, son un componente importante de la dieta por sus propiedades antioxidantes, antiinflamatorias, antialérgicas y supresoras de mutagénesis (Manthey et al, 2001). En los últimos años, se han caracterizado algunos de los genes que participan en el metabolismo de isoprenoides y flavonoides en cítricos como los de biosíntesis de carotenoides (Kato et al, 2004) o algunos genes que codifican monoterpeno (Lücker et al, 2002) o sesquiterpeno sintasas (Sharon-Asa et al, 2003). A pesar de ello, la mayor parte de las rutas de biosíntesis de metabolitos derivados de isoprenoides todavía no se han estudiado en cítricos. En este trabajo se han identificado los genes potencialmente implicados en estas rutas en cítricos, combinando búsquedas de similitud y motivos de secuencia con el conocimiento sobre el metabolismo de isoprenoides y flavonoides en otras especies. Los resultados obtenidos aportan un mayor conocimiento del metabolismo de isoprenoides y flavonoides en cítricos y mejoran substancialmente la anotación génica disponible actualmente. La identificación de estos genes constituye, 
adicionalmente, una herramienta de base con la que abordar la fisiología, la bioquímica y la regulación genética del metabolismo de isoprenoides y flavonoides en cítricos.

\subsection{Biosíntesis de isoprenoides}

\subsubsection{Biosíntesis de isopentenil difosfato y dimetilalil difosfato}

Todos los isoprenoides derivan de un precursor común de cinco carbonos (C5), isopentenil difosfato (IPP), y de su isómero dimetilalil difosfato (DMAPP). Las plantas sintetizan estas unidades C5 mediante dos rutas localizadas en diferentes compartimentos celulares (Fig. 16). En el citosol, la ruta del mevalonato (MVA) produce IPP y DMAPP mientras que en los plastidios se sintetiza IPP y DMAPP por una vía independiente de la del MVA llamada ruta del metileritritol fosfato (MEP) (Rodríguez-Concepción y Boronat, 2002).

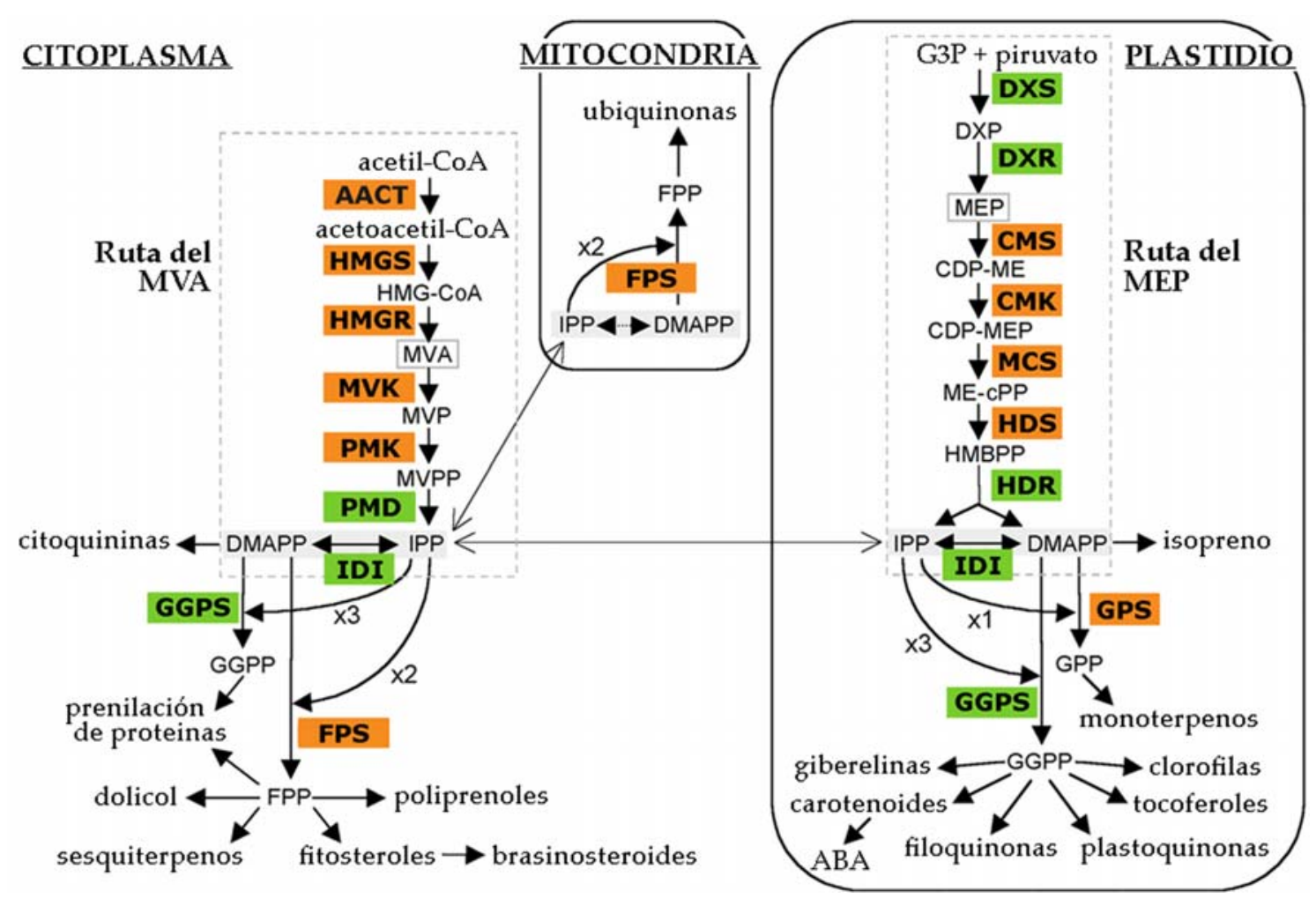

Fig. 16. Biosíntesis de IPP y DMAPP en las células vegetales mediante la ruta citosólica del MVA y la ruta plastidial del MEP. Además, se señalan los metabolitos derivados de la ruta del MVA, cuya síntesis se produce en el citosol, y los derivados del MEP que se sintetizan, al menos en parte, en el plastidio. Las cajas representan los pasos para los que se identificaron los unigenes correspondientes en el conjunto de ESTs del CFGP (en naranja) o para los que se encontró algún representante procedente de la genoteca Veg1 (en verde). 


\section{Biosíntesis de IPP y DMAPP en los plastidios: ruta del MEP}

Las enzimas responsables de la biosíntesis de IPP y DMAPP a través de la ruta del MEP están localizadas en los plastidios (Fig. 16). En el primer paso, 1-deoxiD-xilulosa 5-fosfato sintasa (DXS, EC 2.2.1.7) convierte piruvato y gliceraldehido3-fosfato en 1-deoxi-D-xilulosa 5-fosfato (DXP). La colección de ESTs del CFGP contiene 5 unigenes con secuencias significativamente similares al gen DXS (Tabla 11, Tabla Suplementaria X). En el siguiente paso, DXP reductoisomerasa (DXR, EC 1.1.1.267; 7 unigenes en cítricos) cataliza la formación de metileritritol 4-fosfato (MEP) a partir de DXP. El MEP se convierte en IPP y DMAPP en pasos consecutivos catalizados por 4-difosfocitidil metileritritol sintasa (CMS, EC 2.7.7.60; 1 unigen), 4-difosfocitidil metileritritol kinasa (CMK, EC 2.7.1.148; 1 unigen), metileritritol 2,4ciclodifosfato sintasa (MCS, EC 4.6.1.12; 3 unigenes), hidroximetilbutenil 4-difosfato sintasa (HDS, EC 1.17.4.3; 3 unigenes) y, finalmente, hidroximetilbutenil 4-difosfato reductasa (HDR, EC 1.17.1.2; 7 unigenes). En el conjunto de ESTs del CFGP fue posible identificar, por primera vez en cítricos, los unigenes que posiblemente codifican cada una de las enzimas de la ruta del MEP (Tabla 11; Tabla Suplementaria X).

\begin{tabular}{|c|c|c|c|c|}
\hline Enzimas & EC & Contigs & Singletons & $\begin{array}{c}\mathrm{N}^{\circ} \text { total } \\
\text { ESTs }\end{array}$ \\
\hline \multicolumn{5}{|l|}{ Ruta del metileritritol fosfato } \\
\hline 1-deoxi-D-xilulosa 5-fosfato sintasa (DXS) & 2.2.1.7 & 2 & 3 & 31 \\
\hline 1-deoxi-D-xilulosa 5-fosfato reductoisomerasa (DXR) & 1.1.1.267 & 2 & 5 & 32 \\
\hline 4-difosfocitidil metileritritol sintasa (CMS) & 2.7.7.60 & 0 & 1 & 1 \\
\hline 4-difosfocitidil metileritritol kinasa (CMK) & 2.7.1.148 & 1 & 0 & 2 \\
\hline Metileritritol 2,4-ciclodifosfato sintasa (MCS) & 4.6.1.12 & 2 & 1 & 14 \\
\hline Hidroximetilbutenil 4-difosfato sintasa (HDS) & 1.17.4.3 & 2 & 1 & 31 \\
\hline Hidroximetilbutenil 4-difosfato reductasa (HDR) & 1.17.1.2 & 5 & 2 & 54 \\
\hline Isopentenil difosfato d-isomerasa (IDI) & 5.3.3.2 & 2 & 0 & 34 \\
\hline \multicolumn{5}{|l|}{ Ruta del mevalonato } \\
\hline Acetoacetil-CoA tiolasa (AACT) & 2.3.1.9 & 3 & 6 & 19 \\
\hline Hidroximetilglutaril-CoA sintasa (HMGS) & 2.3.3.10 & 3 & 3 & 28 \\
\hline Hidroximetilglutaril-CoA reductasa (HMGR) & 1.1.1.34 & 3 & 0 & 13 \\
\hline Mevalonato kinasa (MVK) & 2.7.1.36 & 2 & 1 & 6 \\
\hline Fosfomevalonato kinasa (PMK) & 2.7.4.2 & 0 & 1 & 1 \\
\hline Mevalonato difosfato decarboxilasa (PMD) & 4.1.1.33 & 1 & 0 & 6 \\
\hline
\end{tabular}

Las ESTs más abundantes fueron las correspondientes a los genes que codifican HDR e IDI (1\% de las ESTs de la colección) seguidos por DXR, DXS y HDS (1.1\%) (Tabla 11). Estas ESTs aparecieron ampliamente distribuidas en la colección de ESTs del CFGP (generada a partir diferentes tejidos y estadios de desarrollo), lo que sugiere que dichos genes se expresan en toda la planta. En la genoteca Veg1 se 
identificaron ESTs correspondientes a los genes que codifican DXS, DXR, HDR e IDI (Fig. 16) lo que indica la importancia de esta ruta en tejidos vegetativos.

La mayor parte del trabajo sobre la caracterización de las enzimas de la ruta del MEP se ha llevado a cabo en Escherichia coli. Esta ruta constituye un buen ejemplo de cómo, usando información de secuencia, la bioinformática y la genómica comparada han hecho posible identificar de un modo relativamente rápido y simple los genes potencialmente implicados en una ruta metabólica en diferentes organismos (Rodríguez-Concepción y Boronat, 2002). La diferencia más obvia entre las enzimas de la ruta del MEP de plantas y $E$. coli es la presencia de extensiones $\mathrm{N}$-terminales de secuencia y longitud variable en las primeras que funcionan como péptidos señal de plastidios (Rodríguez-Concepción y Boronat, 2002). El análisis de la posible localización subcelular (ver Materiales y Métodos) de las secuencias de aminoácidos deducidas de los unigenes de cítricos que integran la ruta del MEP mostró que todas las secuencias que contienen la región codificante $\mathrm{N}$-terminal completa presentan un péptido señal de plastidio (Tabla 12, Tabla Suplementaria XI), lo que es consistente con su probable función en la biosíntesis plastidial de isoprenoides.

\begin{tabular}{llccc}
\hline \multicolumn{5}{l}{ Tabla 12. Unigenes de cítricos implicados en la ruta MEP } \\
\hline Proteína & $\begin{array}{c}\text { Unigen de } \\
\text { Cítricos }\end{array}$ & $\begin{array}{c}\text { Gen de Arabidopsis } \\
\text { más similar }\end{array}$ & $\begin{array}{c}\text { N-terminal } \\
\text { completa }\end{array}$ & $\begin{array}{c}\text { Longitud } \\
\text { (cTP) }\end{array}$ \\
\hline DXS & aCL303Contig1 & At4g15560 & Sí & $716(36)$ \\
DXR & aCL315Contig1 & At5g62790 & Sí & $473(50)$ \\
CMS & aC34104E04EF_c & At2g02500 & No & - \\
CMK & aCL7203Contig1 & At2g26930 & No & - \\
MCS & aCL1267Contig1 & At1g63970 & Sí & $237(55)$ \\
HDS & aCL234Contig1 & At5g60600 & Sí & $741(48)$ \\
HDR & aCL2Contig14 & At4g34350 & Sí & $464(38)$ \\
IDI & aCL72Contig2 & At3g02780 & Sí & $303(51)$ \\
\hline La longitud de la secuencia de aminoácidos deducida de los unigenes de \\
cítricos así como la longitud del posible péptido señal de plastidio (cTP) se \\
indica en número de aminoácidos.
\end{tabular}

La enzima IPP isomerasa (IDI, EC 5.3.3.2; 2 unigenes) cataliza la conversión reversible de IPP a DMAPP. Esta enzima se ha localizado en plantas tanto en el citosol como en los plastidios (Rodríguez-Concepción y Boronat, 2002); pero, el análisis de las secuencias de los genes de plantas que codifican IDI no permite establecer los dos grupos diferentes de secuencias correspondientes a enzimas citosólicas y plastidiales. Se ha propuesto que un sitio alternativo de iniciación de la traducción podría generar enzimas citosólicas a partir de los mismos genes que codifican las plastidiales (Cunningham y Gantt, 2000). El unigen de cítricos aCL72Contig2 presentó una elevada similitud de secuencia con IPP isomerasa (Fig. 17) y su secuencia deducida de aminoácidos mostró, en su región N-terminal, un 
posible péptido señal de plastidio (Tabla 12, Fig. 17). En la Figura 17 se señalan además dos posibles sitios alternativos al anterior para la traducción, de modo que las proteínas de cítricos obtenidas a partir de estas dos metioninas mostraron una localización subcelular citosólica (ver Materiales y Métodos, Tabla Suplementaria XI) de acuerdo con la hipótesis de Cunningham y Gantt (2000).

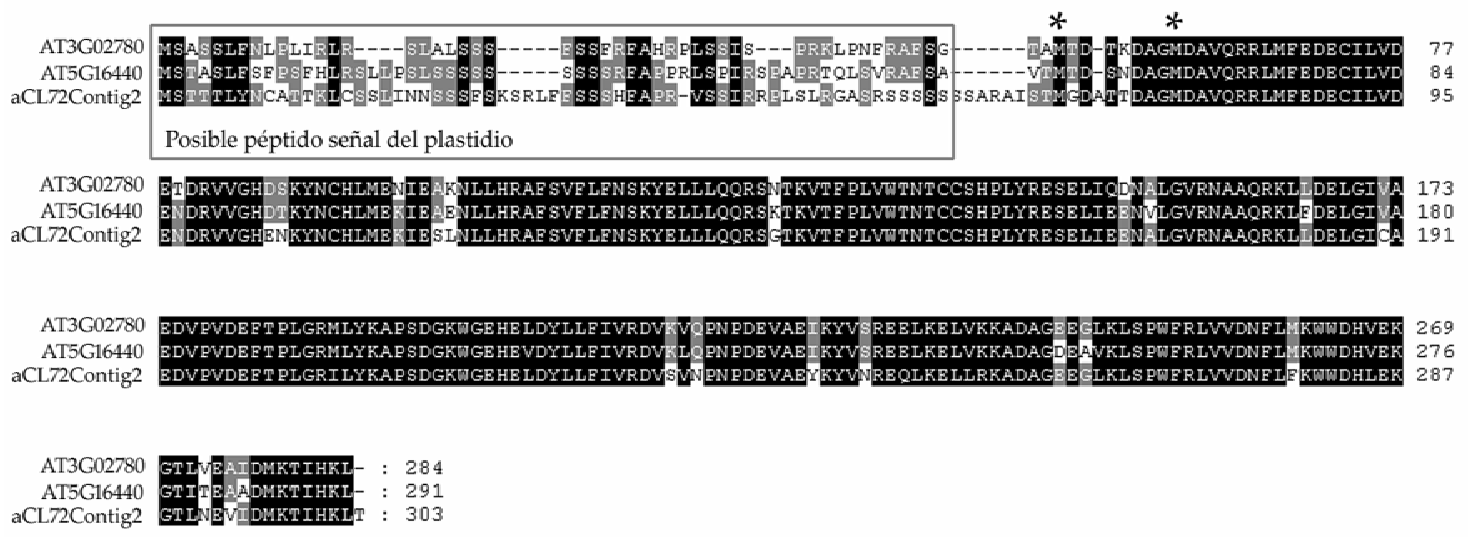

Fig. 17. Alineamiento de las secuencias deducidas de aminoácidos de IDI de Arabidopsis (At3g02780, At5g16440) y de Citrus (aCL72Contig2). El alineamiento se creó con ClustalX 1.83 y se editó en GeneDoc. La caja de la zona N-terminal señala el posible péptido señal de plastidio y las metioninas marcadas constituyen posibles sitios alternativos para la traducción.

\section{Biosíntesis de IPP y DMAPP en el citosol: ruta del MVA}

En el citosol se produce IPP a partir de acetil-CoA mediante la ruta del mevalonato (MVA). El IPP derivado de esta ruta puede ser transportado a la mitocondria para producir isoprenoides mitocondriales (Fig. 16). Todas las enzimas implicadas en la ruta del MVA se encontraron representadas en la colección de ESTs de cítricos del CFGP (Tabla 11, Tabla Suplementaria X). Los primeros pasos de la ruta conducen a MVA e incluyen las enzimas acetoacetil-CoA tiolasa (AACT, EC 2.3.1.9; 9 unigenes), hidroximetilglutaril-CoA sintasa (HMGS, EC 2.3.3.10; 6 unigenes) e hidroximetilglutaril-CoA reductasa (HMGR, EC 1.1.1.34; 3 unigenes). Dos fosforilaciones sucesivas catalizadas por mevalonato kinasa (MVK, EC 2.7.1.36; 3 unigenes) y fosfomevalonato kinasa (PMK, EC 2.7.4.2; 1 unigen) convierten el mevalonato en mevalonato 5-difosfato (MVPP). Finalmente, mevalonato difosfato descarboxilasa (PMD, EC 4.1.1.33; 1 unigen) cataliza la descarboxilación del MVPP para formar IPP (Fig. 16). Para cada unigen de cítricos potencialmente implicado en la ruta del MVA se realizó la predicción de la localización subcelular de su secuencia deducida de aminoácidos (ver Materiales y Métodos, Tabla Suplementaria XI). Este análisis permitió asignar una localización citosólica, coherente con su participación en la ruta del MVA, para AACT, HMGS, HMGR y MVK. Las secuencias de cítricos 
correspondientes a PMK y PMD no contenían la región $\mathrm{N}$-terminal completa por lo que no fue posible la predicción de su localización subcelular (Tabla Suplementaria XI).

Los resultados descritos muestran que las dos rutas de síntesis de IPP y DMAPP están completamente representadas por ESTs de cítricos y, que para la mayor parte de las enzimas implicadas en estas rutas se ha obtenido un cierto grado de redundancia, tanto en términos de ESTs (expresión) como en el número de contigs y singletons (Tabla 11). Esta redundancia sugiere que algunas de las enzimas de biosíntesis de IPP y DMAPP están codificadas por familias génicas en cítricos.

\subsubsection{Prenildifosfatos: precursores de los distintos tipos de terpenoides}

EI DMAPP constituye la unidad inicial para las reacciones de condensación secuenciales, catalizadas por preniltransferasas, que permiten la síntesis de una serie de prenildifosfatos, intermediarios en la síntesis de numerosos isoprenoides (Fig. 18). La adición de una molécula de IPP a DMAPP conduce a la formación de geranil difosfato (GPP), reacción catalizada por la enzima geranil difosfato sintasa (GPS, EC 2.5.1.1; 12 unigenes). La adición de una segunda molécula de IPP al GPP conduce a la formación de farnesil difosfato (FPP), reacción catalizada por farnesil difosfato sintasa (FPS, EC 2.5.1.10; 3 unigenes). La elongación de DMAPP con un total de tres moléculas de IPP forma geranilgeranil difosfato (GGPP) por la acción de la geranilgeranil difosfato sintasa (GGPS, EC 2.5.1.29; 8 unigenes). Los prenildifosfatos GPP, FPP y GGPP son intermediarios en la síntesis de monoterpenos (C10), sesquiterpenos (C15) y diterpenos (C20), respectivamente. La condensación de dos moléculas de FPP da lugar a escualeno (C30), reacción catalizada por escualeno sintasa (EC 2.5.1.21; 1 unigen). La síntesis de triterpenos (C30) como fitosteroles (incluidos los brasinosteroides) y limonoides, deriva de escualeno (Fig. 18). Los tetraterpenos (C40) como carotenoides y ABA se producen a partir de fitoeno, que se sintetiza en dos pasos consecutivos catalizados por fitoeno sintasa (EC 2.5.1.32; 4 unigenes) a partir de GGPP. En el conjunto de ESTs del CFGP fue posible identificar los unigenes de cítricos correspondientes a todas estas preniltransferasas (Tabla 13).

\begin{tabular}{lcrrrc}
\hline \multicolumn{1}{l}{ Tabla 13. Unigenes de cítricos que codifican preniltransferasas } & & & \\
\hline \multicolumn{1}{c}{ Enzima } & EC & Contigs & Singletons & $\begin{array}{c}\text { No }^{\circ} \text { total } \\
\text { ESTs }\end{array}$ & $\begin{array}{c}\text { Localización } \\
\text { subcelular }\end{array}$ \\
\hline Geranil difosfato sintasa (GPS) & 2.5 .1 .1 & 6 & 6 & 20 & $\mathrm{P}$ \\
Farnesil difosfato sintasa (FPS) & 2.5 .1 .10 & 1 & 2 & 4 & $\mathrm{C}$ \\
Geranilgeranil difosfato sintasa (GGPS) & 2.5 .1 .29 & 7 & 1 & 50 & $\mathrm{P}$ \\
Escualeno sintasa (SQS) & 2.5 .1 .21 & 0 & 1 & 1 & - \\
Fitoeno sintasa (PYS) & 2.5 .1 .32 & 2 & 2 & 7 & $\mathrm{P}$ \\
\hline Abreviaturas: P, plastidial; C, citoplasmática; -, región N-terminal incompleta & &
\end{tabular}




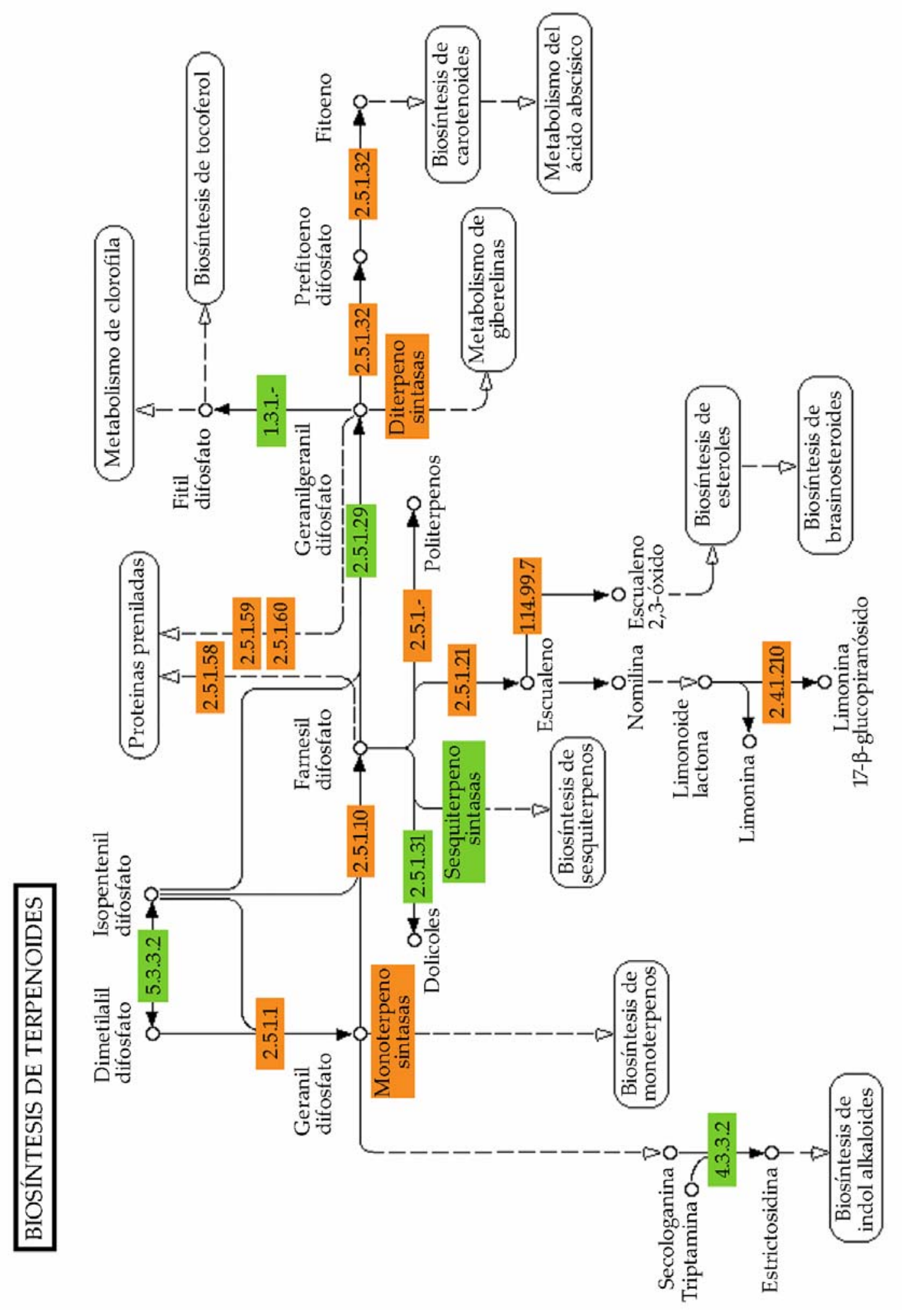

Fig. 18. Biosíntesis de los distintos tipos de terpenoides en cítricos. Las cajas representan los pasos para los que se identificaron los candidatos correspondientes en el conjunto de ESTs del CFGP (en naranja) o para los que se encontró algún representante procedente de la genoteca Veg1 (en verde). 
Un total de 4 ESTs procedentes de la genoteca Veg1 mostraron similitud de secuencia con GGPS, mientras que para el resto de preniltransferasas no se identificaron ESTs en Veg1 (Tabla Suplementaria X). La predicción de la localización subcelular de la secuencia deducida de aminoácidos de los unigenes de cítricos identificados como preniltransferasas permitió asignar, tal como cabía esperar, una localización plastidial para GPS, GGPS y PYS, y citosólica para FPS (Tabla 13, Tabla Suplementaria XI). Las enzimas GPS, GGPS y FPS actúan en los puntos en los que el metabolismo de isoprenoides se ramifica (Fig. 18) por lo que pueden tener un papel clave en el control del flujo de IPP hacia la síntesis de diferentes familias de terpenoides (Lücker et al, 2007). En este sentido se ha demostrado que una reducción en la expresión de GPS en Arabidopsis y en tomate provoca enanismo en las plantas debido a un descenso en el contenido de giberelinas, mientras que los niveles de carotenoides y clorofila no se alteran (van Schie et al, 2007). Por otro lado, la sobreexpresión de PYS en tomate provoca un aumento del contenido de carotenoides en el fruto y un descenso en el contenido de clorofila (Fraser et al, 2007). Estos trabajos muestran que la modificación de la expresión de los genes que codifican preniltransferasas en plantas constituye una importante herramienta biotecnológica para la obtención de ciertos caracteres de interés como una altura reducida de la planta o el aumento en el contenido de carotenoides del fruto.

Además, se identificaron los unigenes de cítricos relacionados con la biosíntesis de diferentes tipos de terpenoides (Tabla 14, Fig. 18). La enzima estrictosidina sintasa (EC 4.3.3.2) está implicada en la biosíntesis de alcaloides derivados de terpenoides catalizando la condensación de triptamina y del monoterpeno secologanina para dar lugar al alcaloide estrictosidina (Ma et al, 2006). Un total de 34 ESTs de cítricos (dos de Veg1), agrupadas en 14 unigenes, presentaron secuencias similares a estrictosidina sintasa (Tabla 14, Tabla Suplementaria X). La enzima dehidrodolicol difosfato sintasa (EC 2.5.1.31) cataliza la síntesis de dehidrodolicol difosfato, prenildifosfato de cadena larga precursor de dolicol difosfato, implicado en la glucosilación de las proteínas (Cunillera et al, 2000). En cítricos se identificaron 18 ESTs (una de ellas procedente de Veg1), agrupadas en dos unigenes, similares a dehidrodolicol difosfato sintasa (Tabla 14, Tabla Suplementaria X). El solanesil difosfato es el precursor de las cadenas laterales de plastoquinona (implicada en el transporte fotosintético de electrones) y ubiquinona (implicada en las reacciones respiratorias mitocondriales). En Arabidopsis, la formación del politerpeno solanesil difosfato (C45), tanto a partir de GGPP como de FPP, está catalizada por la enzima solanesil difosfato sintasa (Hirooka et al, 2003). Dos ESTs de cítricos mostraron secuencias similares a solanesil difosfato sintasa (Tabla 14, Tabla Suplementaria X). 
La prenilación de proteínas es una modificación post-traduccional que implica la unión covalente del grupo prenilo del FPP o del GGPP a las proteínas diana y que tiene un papel importante en rutas de transducción de señal y de tráfico intracelular (Crowell, 2000). La transferencia del grupo prenilo está catalizada por las enzimas farnesiltransferasas (EC 2.5.1.58) y geranilgeraniltransferasas I (EC 2.5.1.59) y II (EC 2.5.1.60). En la colección de ESTs generada en el CFGP se identificaron un total de 35 ESTs cuya secuencia es similar a este grupo de transferasas (Tabla 14, Tabla Suplementaria X).

\begin{tabular}{|c|c|c|c|c|}
\hline Enzima & EC & Contigs & Singletons & $\begin{array}{l}\mathrm{N}^{\circ} \text { total } \\
\text { ESTs }\end{array}$ \\
\hline \multicolumn{5}{|l|}{ Terpenoides derivados de GPP } \\
\hline Monoterpeno sintasas & \multicolumn{4}{|c|}{ Apartado 2.1 .3} \\
\hline Estrictosidina sintasa & 4.3.3.2 & 6 & 8 & 34 \\
\hline \multicolumn{5}{|l|}{ Terpenoides derivados de FPP } \\
\hline Dehidrodolicol difosfato sintasa & 2.5.1.31 & 1 & 1 & 18 \\
\hline Sesquiterpeno sintasas & \multicolumn{4}{|c|}{ Apartado 2.1 .3} \\
\hline Biosíntesis de esteroles & \multicolumn{4}{|c|}{ Anejo II } \\
\hline Biosíntesis de brasinosteroides & \multicolumn{4}{|c|}{ Apartado 2.1.4 } \\
\hline Biosíntesis de limonoides & \multicolumn{4}{|c|}{ Apartado 2.1 .4} \\
\hline \multicolumn{5}{|c|}{ Terpenoides derivados de FPP y GGPP } \\
\hline Solanesil difosfato sintasa & 2.5.1.- & 1 & 0 & 2 \\
\hline Biosíntesis de plastoquinona & \multicolumn{4}{|c|}{ Anejo II } \\
\hline Biosíntesis de ubiquinona & \multicolumn{4}{|c|}{ Anejo II } \\
\hline Farnesiltransferasas & 2.5.1.58 & 3 & 0 & 11 \\
\hline Geranilgeraniltransferasas I & 2.5.1.59 & 1 & 0 & 2 \\
\hline Geranilgeraniltransferasas II & 2.5.1.60 & 3 & 1 & 22 \\
\hline \multicolumn{5}{|l|}{ Terpenoides derivados de GGPP } \\
\hline Biosíntesis de tocoferol & \multicolumn{4}{|c|}{ Anejo II } \\
\hline Biosíntesis de carotenoides & \multicolumn{4}{|c|}{ Anejo II } \\
\hline Metabolismo de ácido abscísico & \multicolumn{4}{|c|}{ Anejo II } \\
\hline Metabolismo de giberelinas & \multicolumn{4}{|c|}{ Apartado 2.1 .5} \\
\hline
\end{tabular}

En el Anejo II se representan las rutas de biosíntesis de tocoferol, biosíntesis de carotenoides, metabolismo de ácido abscísico y biosíntesis de plastoquinona y de ubiquinona, así como los unigenes identificados en este trabajo que codifican las enzimas que catalizan cada uno de los pasos de estas rutas en cítricos. Los resultados muestran que casi todos los pasos de estas rutas están representados por ESTs de cítricos y que, en general, el número de unigenes de cítricos que corresponde a enzimas implicadas en estas rutas es elevado. La posible presencia de familias génicas que codifican enzimas del metabolismo de isoprenoides facilita, probablemente, una ajustada regulación de la expresión de isoenzimas específicas en ciertos tejidos, estadios de desarrollo y/o condiciones ambientales. Es posible que la secuenciación adicional de ESTs de cítricos permita agrupar algunos singletons en contigs, reduciendo así el tamaño del conjunto de unigenes obtenido en el CFGP y, 
por tanto, una parte de la redundancia génica observada en las rutas del metabolismo de isoprenoides. Sin embargo, recientemente se ha estudiado con detalle la ruta de biosíntesis de lignina en cítricos y los resultados muestran que algunas enzimas están codificadas por un mayor número de genes en cítricos que en Arabidopsis (Terol et al, 2007). Estos resultados apoyan la existencia de una 'expansión' de los genes implicados en las rutas derivadas del metabolismo de isoprenoides.

\subsubsection{Biosíntesis de monoterpenos y sesquiterpenos: aceites esenciales}

En cítricos, los aceites esenciales constituyen uno de los principales productos y se obtienen tanto de la piel del fruto mediante presión en frío como de las hojas por destilación en corriente de vapor. La composición de los aceites esenciales varía mucho entre especies, variedades e, incluso para un mismo cultivar, entre la piel del fruto y las hojas. Esta variabilidad parece deberse principalmente a la expresión de diferentes terpeno sintasas, enzimas clave en la biosíntesis de mono-, sesqui- y diterpenos (Fig. 18). En los últimos años se han aislado y caracterizado algunos genes que codifican terpeno sintasas del género Citrus, tanto monoterpeno sintasas (Lücker et al, 2002; Shimada et al, 2004) como sesquiterpeno sintasas (Maruyama et al, 2001; Sharon-Asa et al, 2003). Con objeto de identificar nuevos genes que codifican terpeno sintasas en cítricos, se utilizaron las secuencias previamente caracterizadas como motores de búsqueda en la base de datos del CFGP. Este método permitió identificar un total de 54 ESTs, agrupadas en 11 unigenes cuya secuencia es similar a monoterpeno sintasas, 12 unigenes similares a sesquiterpeno sintasas (Tabla 15, Tabla Suplementaria XII) y 5 unigenes similares a terpeno sintasas (Tabla Suplementaria XII).

\begin{tabular}{|c|c|c|c|c|c|}
\hline Posible función & Unigen & $\mathrm{N}^{\circ}$ ESTs & Posible función & Unigen & $\mathrm{N}^{\circ}$ ESTs \\
\hline \multicolumn{3}{|c|}{ Monoterpeno sintasas } & \multicolumn{3}{|c|}{ Sesquiterpeno sintasas } \\
\hline \multirow[t]{4}{*}{ Limoneno sintasa } & aCL2450Contig1 & 3 & $\beta$-Farneseno sintasa & $\mathrm{aC} 01017 \mathrm{~A} 08$ & 1 \\
\hline & aCL2450Contig2 & 6 & & aC06010C07 & 1 \\
\hline & aC02013A08 & 1 & & aCL9256Contig1 & 2 \\
\hline & alC0AAA64DH02 & 1 & & aKNOAAB3AE04 & 1 \\
\hline$\gamma$-Terpineno sintasa & aCL3564Contig1 & 5 & & aKNOAAL1DG10 & 1 \\
\hline$\beta$-Pineno sintasa & aKNOAAI2CC06 & 1 & Valenceno sintasa & aCL7292Contig1 & 2 \\
\hline \multirow[t]{3}{*}{ Linalol sintasa } & aCL4530Contig1 & 4 & & aC06019E08 & 1 \\
\hline & aCL4629Contig1 & 4 & Germacreno D sintasa & aC32011H02 & 1 \\
\hline & aKNOAAM2BC07 & 1 & & aKN0AAP6YP01 & 1 \\
\hline \multirow[t]{3}{*}{$\alpha$-Terpineol sintasa } & alC0AAA51DF11 & 1 & & aC32102B11 & 1 \\
\hline & $\mathrm{aC} 06019 \mathrm{H} 04$ & 1 & & aCL6701Contig1 & 2 \\
\hline & & & & aCL4874Contig1 & 4 \\
\hline
\end{tabular}




\section{Monoterpeno sintasas de cítricos}

Las monoterpeno sintasas convierten el geranil difosfato (GPP) en diferentes monoterpenos (C10) en los plastidios, por lo que la región $\mathrm{N}$-terminal de todas las monoterpeno sintasas caracterizadas en plantas contiene un péptido señal de plastidio. En este trabajo se identificaron un total de 28 ESTs, agrupadas en 11 unigenes (5 contigs y 6 singletons), que codifican posibles monoterpeno sintasas en cítricos (Tabla 15, Tabla Suplementaria XII). Cuatro unigenes de cítricos (11 ESTs) mostraron secuencias deducidas de aminoácidos muy similares a limoneno sintasa de Citrus limon (Lücker et al, 2002) y de Citrus unshiu (Shimada et al, 2004) (Fig. 19).

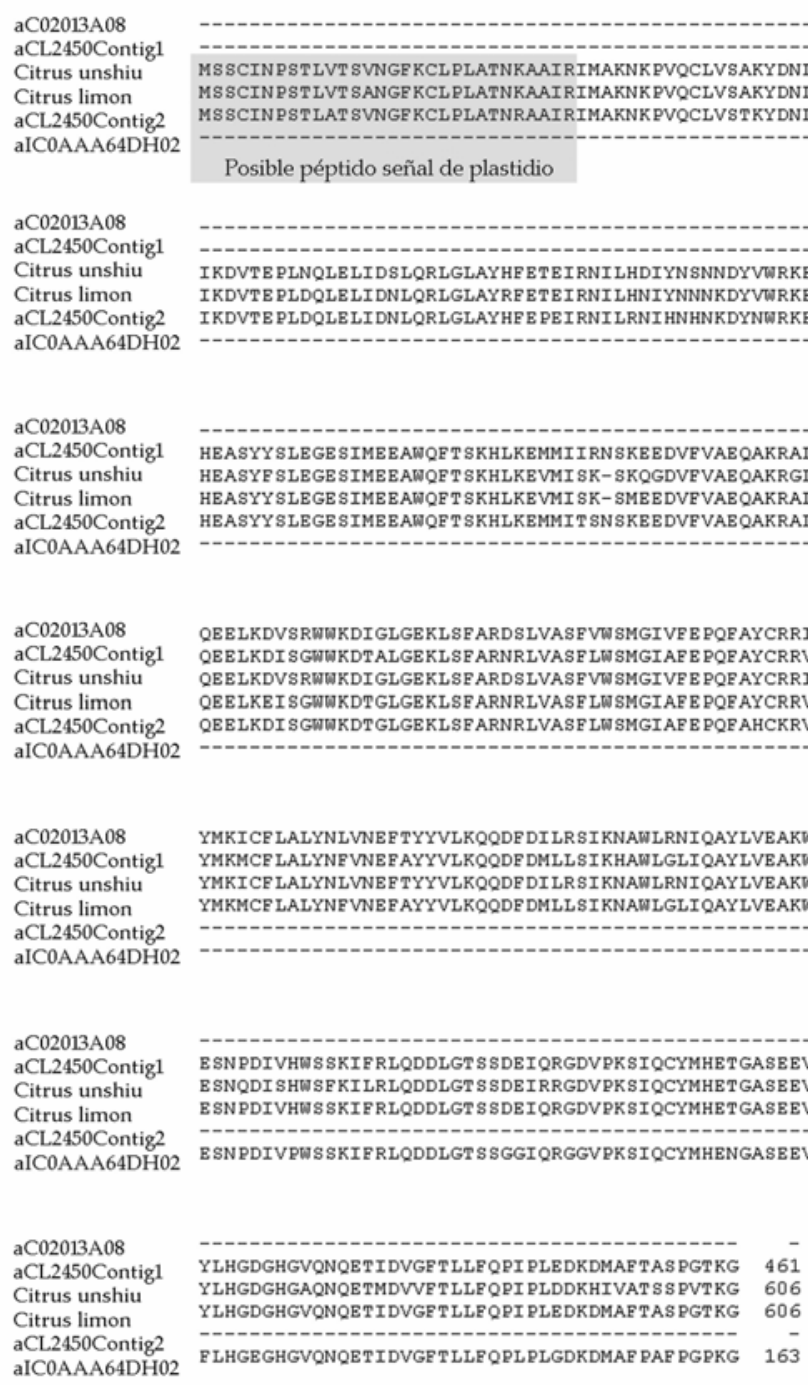

Fig. 19. Alineamiento de las secuencias de aminoácidos deducidas de los unigenes de cítricos identificados en este trabajo con las limoneno sintasas de Citrus limon (AF514289) y Citrus unshiu (AB110636). El alineamiento se creó con ClustalX 1.83 y se editó en GeneDoc. La caja sombreada señala el posible péptido señal de plastidio y las cajas huecas los motivos $\mathrm{RR}_{8} \mathrm{~W}$ y DDxD característicos de monoterpeno sintasas. 
En la región $\mathrm{N}$-terminal de la secuencia deducida de aminoácidos del unigen aCL2450Contig2 se detectó un posible péptido señal de plastidio de 30 aminoácidos aguas arriba del motivo $\mathrm{RRx}_{8} \mathrm{~W}$ conservado en monoterpeno sintasas (Bohlmann et al, 1998). Aunque los unigenes aCL2450Contig1 y aC02013A08 carecían de la región $\mathrm{N}$-terminal completa fue posible identificar el motivo DDxxD conservado en terpeno sintasas (Starks et al, 1997) (Fig. 19). La secuencia de aminoácidos deducida del unigen aCL3564Contig1 fue muy similar a $\gamma$-terpineno sintasa (97\% de identidad, 99\% de similitud) de Citrus limon (Lücker et al, 2002) y presentó un posible péptido señal de plastidio de 40 aminoácidos aguas arriba del motivo conservado $\mathrm{RR} \mathrm{x}_{8} \mathrm{~W}$. El unigen aKNOAAI2CC06 fue muy similar a $\beta$-pineno sintasa de Citrus limon ( $97 \%$ de identidad, 98\% de similitud) (Lücker et al, 2002) y de Citrus unshiu (94\% de identidad, 96\% de similitud) (Shimada et al, 2004). La región $\mathrm{N}$-terminal de la secuencia de aminoácidos de este unigen mostró un posible péptido señal de plastidio de 22 aminoácidos y el motivo $\mathrm{RRx}_{8} \mathrm{~W}$.

Este trabajo permitió identificar, adicionalmente, unigenes cuyas secuencias son similares a monoterpeno sintasas que todavía no se han caracterizado en cítricos (Tabla Suplementaria XII). La secuencia deducida de aminoácidos de los unigenes aCL4530Contig1 y aCL4629Contig1 fue similar a linalol sintasa de Arabidopsis, At1g61680 (Chen et al, 2003b) (59\% de identidad, 75\% de similitud) y At1g61120 (44\% de identidad, $62 \%$ de similitud), respectivamente. Por otro lado, el unigen alC0AAA51DF11 fue similar a $\alpha$-terpineol sintasa (42\% de identidad, $66 \%$ de similitud) de Vitis vinifera (Martin y Bohlmann, 2004).

\section{$\underline{\text { Sesquiterpeno sintasas de cítricos }}$}

Las sesquiterpeno sintasas convierten el farnesil difosfato (FPP) en diferentes sesquiterpenos (C15) en el citosol, por lo que la región N-terminal carece de péptido señal de plastidio. En este trabajo se identificaron un total de 18 ESTs, agrupadas en 12 unigenes (4 contigs y 8 singletons), que codifican posibles sesquiterpeno sintasas en cítricos (Tabla 15, Tabla Suplementaria XII). Cinco unigenes de cítricos fueron muy similares a $\beta$-farneseno sintasa de Citrus junus (Maruyama et al, 2001): aCL9256Contig1 (99\% de identidad, 99\% de similitud), aKNOAAB3AE04 (97\% de identidad, 98\% de similitud), aC01017A08 (95\% de identidad, 98\% de similitud) y aKNOAAL1DG10 y aC06010C07 (que mostraron menor grado de similitud) (Tabla Suplementaria XII). La secuencia deducida de aminoácidos del unigen aCL9256Contig1 presentó el motivo $\mathrm{RRx}_{8} \mathrm{~W}$, a 21 aminoácidos del extremo N-terminal, 
y el motivo $\mathrm{DDxxD}$. La corta región $\mathrm{N}$-terminal aguas arriba del motivo $\mathrm{R} R \mathrm{x}_{8} \mathrm{~W}$ resultó indicadora de la ausencia de un péptido señal de plastidio, consistente con la localización citosólica de sesquiterpeno sintasas.

El unigen aCL7292Contig1 presentó una similitud elevada (99\% de identidad, 99\% de similitud) con valenceno sintasa de Citrus sinensis (Sharon-Asa et al, 2003). La región $\mathrm{N}$-terminal de la secuencia deducida de aminoácidos del mismo mostró el motivo $\mathrm{RRx}_{8} \mathrm{~W}$ conservado en sesquiterpeno sintasas. La secuencia de aminoácidos del unigen aC06019E08 resultó idéntica a valenceno sintasa de Citrus sinensis.

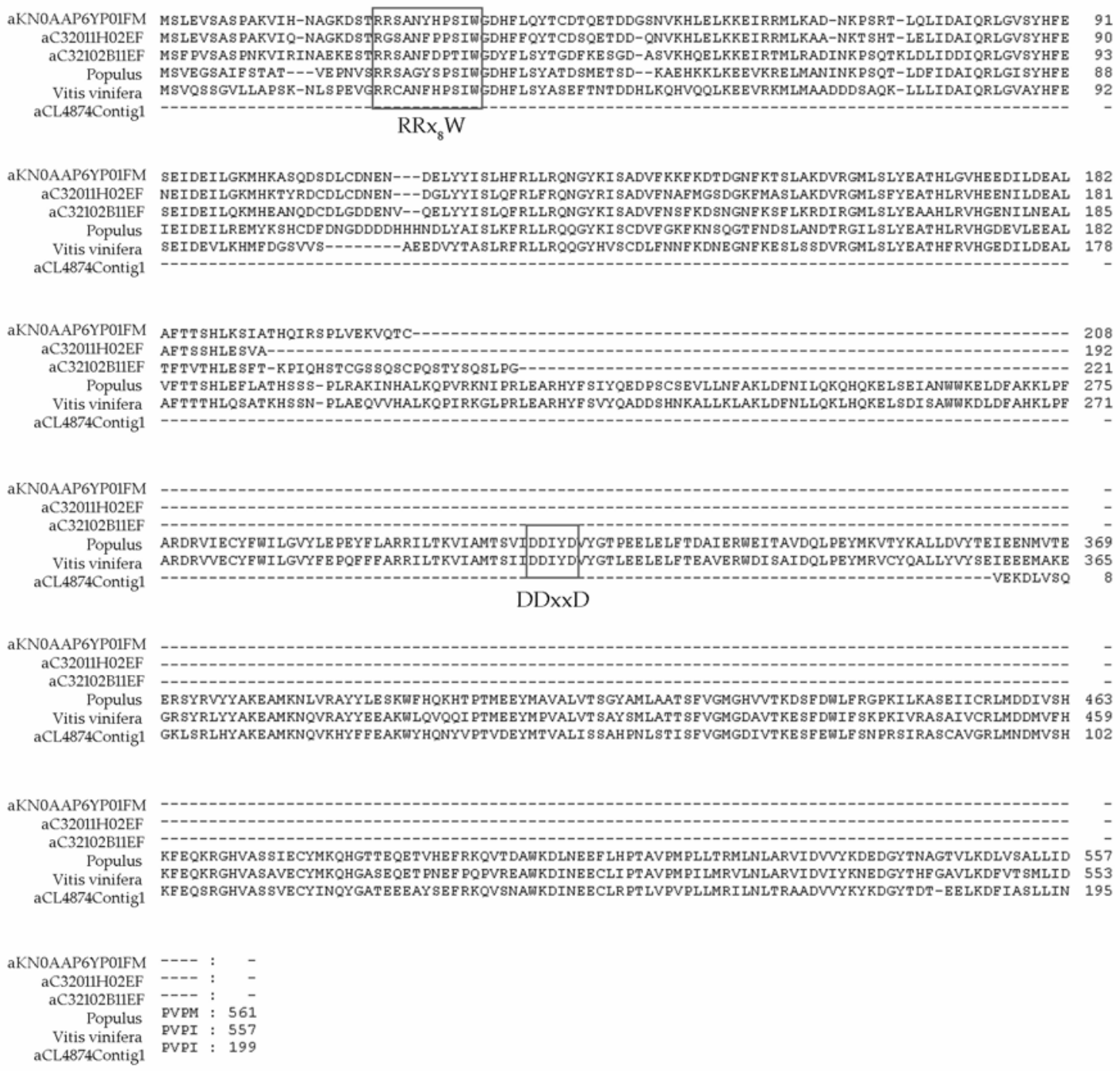

Fig. 20. Alineamiento de las secuencias de aminoácidos deducidas de los unigenes de cítricos identificados en este trabajo con germacreno D sintasa de Populus (AAR99061) y de Vitis vinifera (AAS66357). El alineamiento se creó con ClustalX 1.83 y se editó en GeneDoc. Las cajas huecas señalan los motivos $\mathrm{RRx}_{8} \mathrm{~W}$ y $\mathrm{DDxD}$ característicos de sesquiterpeno sintasas. 
En el análisis de los unigenes de cítricos que mostraron similitud de secuencia con diversas sesquiterpeno sintasas también fue posible identificar cinco unigenes con secuencias similares a germacreno sintasa (una sesquiterpeno sintasa) que, hasta el momento, no ha sido descrita ni caracterizada en cítricos (Tabla 15, Tabla Suplementaria XII). Las secuencias de los unigenes aC32011H02EF, aC32102B11, aKN0AAP6YP01FM y aCL4874Contig1 resultaron similares (Fig. 20) a germacreno D sintasa de chopo (Arimura et al, 2004) y de vid (Lücker et al, 2004). Los tres primeros presentaron el motivo $\mathrm{RRx}_{8} \mathrm{~W}$ conservado en sesquiterpeno sintasas y su región $\mathrm{N}$-terminal no mostró péptidos señal de plastidio. El unigen aCL4874Contig1 fue similar a germacreno D sintasa (61\% de identidad, $79 \%$ similitud) de vid (Fig. 20).

\section{Otras terpeno sintasas de cítricos}

Adicionalmente a las terpeno sintasas descritas en los apartados anteriores, en el conjunto de ESTs de cítricos del CFGP se identificaron 8 ESTs, agrupadas en 5 unigenes, que presentaron similitud con terpeno sintasas (Tabla Suplementaria XII). Los unigenes aCL4500Contig1 y alC0AAA81DA02 mostraron similitud con terpeno sintasas de Medicago truncatula (Gómez et al, 2005) y los unigenes alC0AAA1CC04 y alC0AAA53DC12 fueron similares a terpeno sintasas de Citrus junus (AF288465). La secuencia deducida de aminoácidos de alC0AAA1CC04, pese a contener la región $\mathrm{N}$-terminal completa, no mostró péptido señal de plastidio por lo que podría clasificarse como sesquiterpeno sintasa.

Los análisis de homología de terpeno sintasas (TPS) muestran que, aunque el grado de conservación a nivel de secuencia no es elevado entre TPS de distintas especies vegetales, existen algunos dominios conservados que sugieren una similitud significativa en estructura y función (Steele et al, 1998). Estos dominios conservados han sido la base para aislar genes que codifican TPS en diversas especies vegetales utilizando RT-PCR con oligonucleótidos degenerados (por ejemplo Bohlmann et al, 1998; Sharon-Asa et al, 2003). Actualmente, la existencia de bases de datos de ESTs de un número creciente de especies vegetales facilita la búsqueda de genes que codifican TPS. Esta aproximación ha permitido identificar diversas TPS en vid (Martin y Bohlmann, 2004; Lücker et al, 2004). En este trabajo se ha utilizado la colección de ESTs de cítricos generada por el CFGP junto con la información de secuencia de diferentes TPS de otras especies vegetales para identificar un total de 28 unigenes de cítricos que codifican posibles TPS. La identificación de estos unigenes muestra que la familia de TPS en Citrus es una de las más amplias y diversas en plantas. Sin embargo, resulta necesario señalar que la función atribuida a estos unigenes es una 
predicción que debe confirmarse mediante ensayos de actividad de las enzimas codificadas por los correspondientes unigenes.

La caracterización de los unigenes identificados en este trabajo permitirá abordar, con herramientas moleculares, la regulación de la formación del sabor y del aroma durante el desarrollo del fruto en cítricos. Estos genes pueden constituir, adicionalmente, marcadores moleculares para asistir la mejora de variedades de cítricos superiores en sabor, aroma y propiedades nutricionales. Finalmente, el aislamiento de genes que codifican terpeno sintasas en cítricos tiene interés en aplicaciones biotecnológicas como la producción de aromas en E. coli o en sistemas de fermentación de levaduras manipulados para la producción de terpenos (Martin et al, 2003; Reiling et al, 2004).

\subsubsection{Biosíntesis de triterpenos: brasinosteroides y limonoides}

\section{Biosíntesis de brasinosteroides}

Los brasinosteroides (BRs) son un grupo de hormonas vegetales que regulan el crecimiento y desarrollo de las plantas (Fujioka y Yokota, 2003). Los BRs pertenecen al grupo de triterpenos y constituyen un grupo de esteroles modificados, por lo que su biosíntesis puede dividirse en dos partes: 1) síntesis de campesterol (CR) a partir de escualeno y 2) síntesis de brasinólido (BL), BR biológicamente activo, a partir de CR (Fig. 21). La oxidación del escualeno, catalizada por escualeno monooxigenasa (EC 1.14.99.7; 4 unigenes), conduce a la formación de 2,3-oxidoescualeno (Fig. 18), que posteriormente es modificado para producir fitosteroles como sitosterol y campesterol. En el Anejo II se presenta la ruta de biosíntesis de esteroles en plantas así como los unigenes de cítricos identificados en este trabajo como candidatos a codificar las enzimas que catalizan cada uno de los pasos de dicha ruta.

La ruta específica de biosíntesis de $\mathrm{BL}$ comienza con la conversión de campesterol en campestanol mediante varios pasos de reducción del doble enlace del C5 (Fig. 21). Uno de estos pasos ha sido caracterizado en detalle en Arabidopsis y corresponde a una $5 a$ reductasa codificada por el gen DET2 (At2g38050). La secuencia deducida de aminoácidos del unigen aC31805H09 de cítricos fue similar a DET2 (64\% de identidad, 81\% de similitud) de Arabidopsis (Li et al, 1996). Los niveles endógenos de campestanol en el mutante det2 de Arabidopsis son del $10 \%$ respecto al control (Fujioka et al, 1997) lo que sugiere la existencia de otras $5 a$ reductasas que catalizan la misma reacción (Clouse, 2002). En Arabidopsis se han identificado 
homólogos funcionales a DET2 como At3g55360 y At5g16010 (AraCyc), para los que también se encontraron unigenes similares en cítricos (Tabla 16). A partir de campestanol se sintetiza BL mediante dos rutas paralelas: la ruta de la oxidación temprana en C-6 y la ruta de la oxidación tardía en C-6 (Fig. 21).

\section{BIOSÍNTESIS DE BRASINOSTEROIDES}

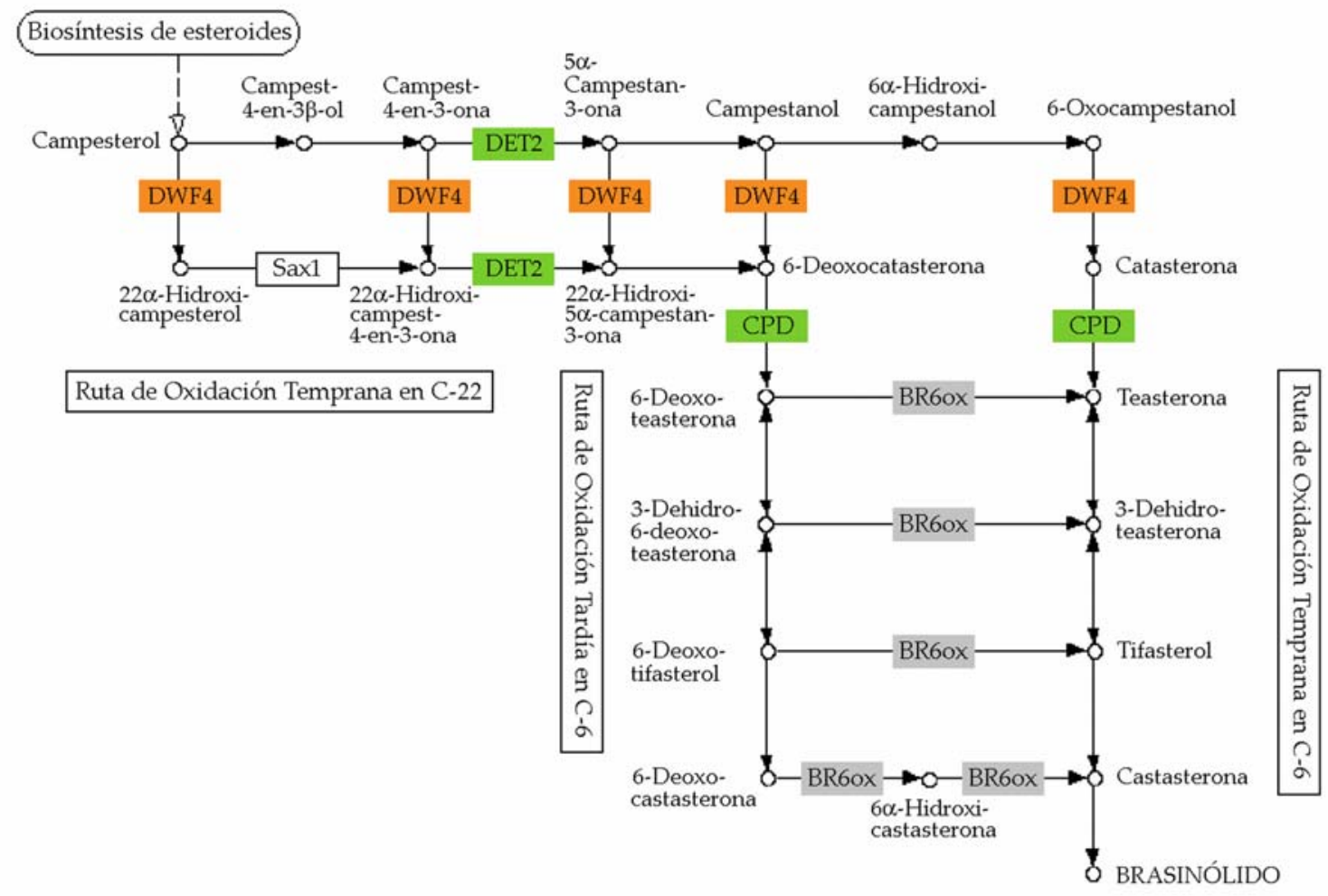

Fig. 21. Biosíntesis de brasinosteroides en cítricos. Las cajas señalan los pasos para los que se identificaron unigenes en el conjunto de ESTs del CFGP (en naranja), para los se encontró algún representante procedente de la genoteca Veg1 (en verde) o para los que ninguna EST de cítricos mostró similitud significativa de secuencia (en gris). El gen sax1 todavía no se ha clonado en ninguna especie vegetal.

La conversión de campestanol a 6-deoxocatasterona (ruta de la oxidación tardía en C-6) y de 6-oxocampestanol a catasterona (ruta de la oxidación temprana en C-6) está catalizada por una $22 \alpha$ hidroxilasa, función codificada en Arabidopsis por el gen DWF4 (At3g50660) (Choe et al, 1998). En la base de datos del CFGP se identificaron dos unigenes (aCL2095Contig1 y aCL2095Contig2), cuyas secuencias de aminoácidos fueron similares (66\% de identidad, $76 \%$ de similitud y $74 \%$ de identidad, $86 \%$ de similitud, respectivamente) a DWF4 de Arabidopsis (Tabla 16). El siguiente paso, en ambas ramas de la ruta, implica la hidroxilación del C-23, que en Arabidopsis está catalizada por el producto del gen CPD (At5g05690) (Szekeres et al, 1996). Recientemente se han caracterizado dos nuevas C-23 hidroxilasas en Arabidopsis 
(CYP90C1 y CYP90D1) codificadas por los genes At4g36380 y At3g13730, respectivamente (Ohnishi et al, 2006). Los unigenes de cítricos cuyas secuencias mostraron similitud con las C-23 hidroxilasas descritas en Arabidopsis se recogen en la Tabla 16.

\begin{tabular}{cccrr}
\hline Tabla 16. Unigenes de cítricos que codifican enzimas de la biosíntesis de BRs \\
\hline Enzimas & $\begin{array}{c}\text { Unigen } \\
\text { de cítricos }\end{array}$ & $\begin{array}{c}\text { Gen de ATH } \\
\text { más similar }\end{array}$ & Valor $E$ & $\begin{array}{c}N^{\circ} \text { total } \\
\text { ESTs }\end{array}$ \\
\hline Esteroide 5a reductasa (DET2) & aC31805H09 & At2g38050 & $2 \mathrm{E}-62$ & 1 \\
& aCL5912Contig1 & At3g55360 & $1 \mathrm{E}-145$ & 3 \\
aC01011F03 & At5g16010 & $7 \mathrm{E}-41$ & 1 \\
Esteroide C-22 $\alpha$ hidroxilasa & & & & \\
(DWF4, CYP90B1) & aCL2095Contig1 & At3g50660 & 0 & 4 \\
& aCL2095Contig2 & At3g50660 & $1 \mathrm{E}-154$ & 6 \\
Esteroide C-23a hidroxilasa & & & & \\
(CPD, CYP90A1) & aCL1811Contig1 & At5g05690 & 0 & 8 \\
& aCL1811Contig2 & At5g05690 & $1 \mathrm{E}-100$ & 2 \\
& aC08025D05 & At5g05690 & $7 \mathrm{E}-74$ & 1 \\
(CYP90D1) & alC0AAA98BE11 & At3g13730 & $2 \mathrm{E}-78$ & 1 \\
(CYP90C1) & - & At4g36380 & - & - \\
Esteroide C-6 oxidasa (BR6ox) & - & At5g38970 & - & - \\
& - & At3g30180 & - & - \\
\hline
\end{tabular}

En tomate, Arabidopsis y arroz se han caracterizado las enzimas que catalizan la conversión de 6-deoxocastasterona a castasterona mediante C-6 oxidación (Bishop et al, 1999; Shimada et al, 2001; Hong et al, 2002) (Fig. 21). En Arabidopsis, existen en dos isoformas (codificadas por los genes At5g38970 y At3g30180) para la enzima esteroide C-6 oxidasa (Tabla 16). La colección de ESTs del CFGP contiene 85,965 ESTs generadas a partir de 52 genotecas de cDNA que cubren un amplio rango de tejidos, estadios de desarrollo y condiciones de estrés biótico y abiótico. Sin embargo, no se identificó ninguna EST de cítricos cuya secuencia fuera similar a esteroide C-6 oxidasa (Tabla 16). En Arabidopsis, guisante y tomate abundan los intermediarios 6-deoxo (Nomura et al, 2001), lo que indica que la ruta de la oxidación tardía en C-6 es la principal. No obstante, la ausencia de ESTs de cítricos con similitud de secuencia a esteroide C-6 oxidasa puede indicar que la ruta de la oxidación temprana en C-6 es la ruta de biosíntesis de BRs predominante en cítricos.

Los BRs constituyen un grupo de compuestos polihidroxilados derivados de esteroles que se han identificado en un amplio rango de especies vegetales (Bajguz y Tretyn, 2003). Sin embargo, hasta la fecha, los BRs no han sido estudiados en cítricos. En nuestro trabajo hemos identificado, por primera vez, los unigenes de cítricos que codifican esteroide $5 \alpha$ reductasa, esteroide C-22 $\alpha$ hidroxilasa y esteroide C-23a hidroxilasa (Tabla 16); aunque resulta necesario señalar que la función atribuida a 
estos genes se basa en similitud de secuencia y debe confirmarse mediante ensayos de actividad de las correspondientes enzimas.

\section{Biosíntesis de limonoides en cítricos}

Los limonoides constituyen un grupo de triterpenos altamente oxigenados presentes sólo en el orden Rutales, principalmente en las familias Rutaceae (a la que pertenece el género Citrus) y Meliaceae (Moriguchi et al, 2003). En cítricos se dan dos formas químicas: agliconas (amargas) y glucósidos (no amargos). El precursor inicial de los limonoides conocidos en cítricos es la nomilina, que se sintetiza en el floema a partir de escualeno (Fig. 22). Este precursor migra a las hojas, frutos y semillas donde se sintetizan diversos limonoides, fundamentalmente obacunona y limonina. Estas agliconas amargas se convierten en 17- $\beta$-D-glucopiranósido derivados no amargos, como limonina 17- $\beta$-D-glucopiranósido, el limonoide glucósido más abundante en cítricos, durante la maduración del fruto (Moriguchi et al, 2003).

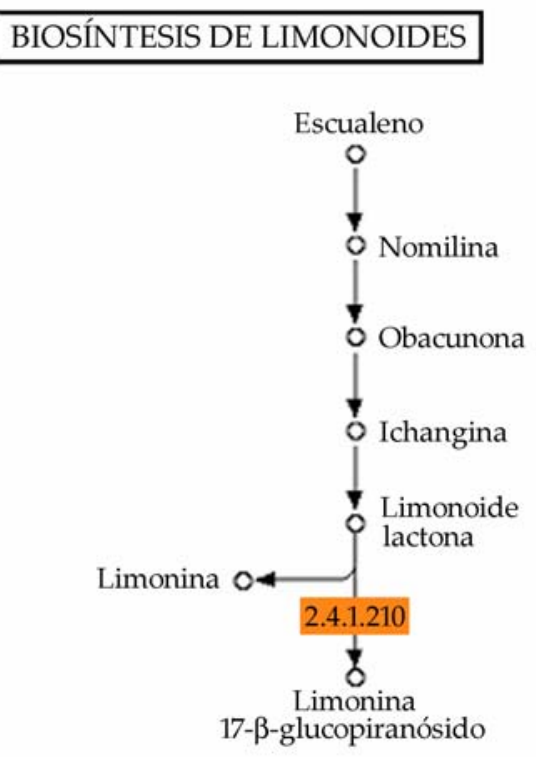

Fig. 22. Biosíntesis de limonoides en cítricos. El gen que codifica limonoide UDP-glucosiltransferasa (EC 2.4.1.210) está representado en la colección de ESTs del CFGP.

Este proceso natural de pérdida de amargor está catalizado por la enzima UDP-D-glucosa:limonoide glucosiltransferasa (LGT, EC 2.4.1.210). El gen que codifica esta enzima ha sido clonado y caracterizado a partir de frutos de Citrus unshiu (Kita et al, 2000). El unigen aCL770Contig1 del CFGP muestra una similitud de secuencia elevada ( $97 \%$ de identidad, $98 \%$ de similitud) con este gen. Este unigen está formado por 17 ESTs, ninguna de ellas procedente de genotecas generadas a partir de tejidos 
vegetativos, lo que es consistente con que el sitio de metabolización de limonoides agliconas a glucósidos está limitado a la semilla y al fruto maduro (Kita et al, 2000).

\subsubsection{Biosíntesis de diterpenos: giberelinas}

Las giberelinas (GAs) constituyen un grupo de hormonas vegetales que controlan diversos aspectos del desarrollo como la germinación, la expansión de las hojas, la elongación del tallo y de la raíz, el tiempo de floración y el desarrollo de la flor y del fruto (Sponsel y Hedden, 2004; Swain y Singh, 2005). Las GAs forman un grupo de diterpenos tetracíclicos que se sintetizan a partir del precursor común geranilgeranil difosfato (Fig. 23).

\section{METABOLISMO DE GIBERELINAS}

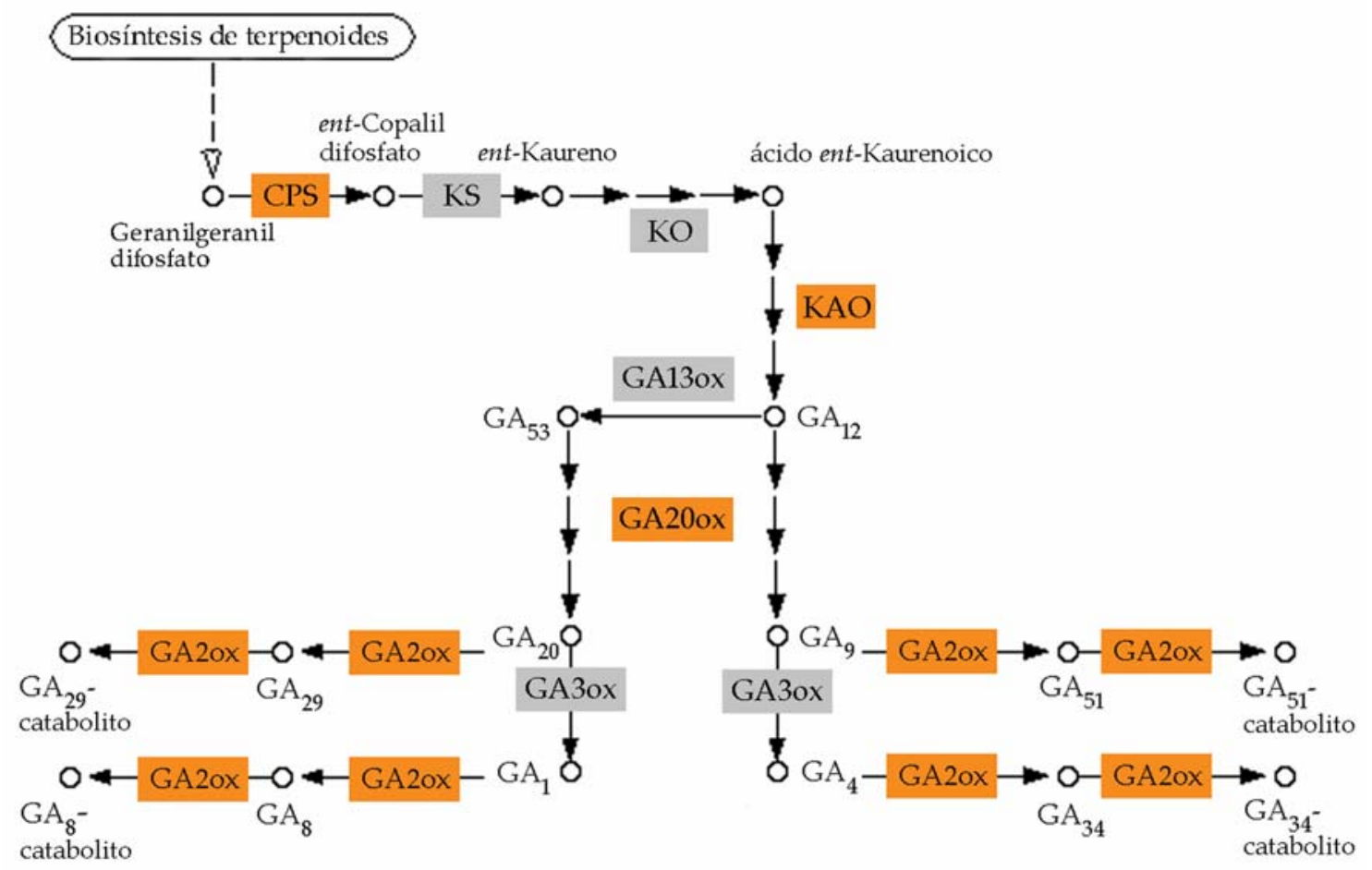

Fig. 23. Metabolismo de giberelinas en cítricos. Las cajas naranjas señalan los pasos para los que se identificaron unigenes en el conjunto de ESTs del CFGP y las grises los pasos para los que ninguna ESTs de cítricos mostró similitud significativa de secuencia.

Los dos primeros pasos de la biosíntesis de GAs están catalizados por dos diterpeno sintasas, copalil difosfato sintasa (CPS, EC 5.5.1.13) y ent-kaureno sintasa (KS, EC 4.2.3.19) y conducen a la formación de ent-kaureno. A continuación, dos monooxigenasas dependientes de citocromo P450, ent-kaureno oxidasa (KO, EC 1.14.13.78) y ácido ent-kaurenoico oxidasa (KAO, EC 1.14.13.79), catalizan la 
conversión de ent-kaureno en $\mathrm{GA}_{12}$ y $\mathrm{GA}_{53}$. Finalmente, dos dioxigenasas dependientes de 2-oxoglutarato, GA 20-oxidasas (GA20ox, EC 1.14.11.12) y GA 3-oxidasas (GA3ox, EC 1.14.11.15), actúan consecutivamente para producir las GAs bioactivas $\left(G_{1}\right.$ y $\left.G_{4}\right)$ a través de dos rutas paralelas: la ruta de la hidroxilación temprana en $\mathrm{C}-13$ (que conduce a la formación de $\mathrm{GA}_{1}$ ) y la ruta de la no hidroxilación en C-13 (mediante la que se sintetiza $\mathrm{GA}_{4}$ ). Una tercera clase de dioxigenasas, GA 2-oxidasas (GA2ox, EC 1.14.11.13), inactivan tanto las $G A s$ bioactivas $\left(G_{1}\right.$ y $\left.G A_{4}\right)$ como sus precursores inmediatos $\left(\mathrm{GA}_{20}\right.$ y $\left.\mathrm{GA}_{9}\right)$ (Fig. 23).

En el conjunto de ESTs generado a partir de la genoteca Veg1 de tejidos vegetativos no se identificó ninguna EST relacionada con el metabolismo de GAs. Sin embargo, en el conjunto de ESTs del CFGP se identificaron un total de 11 ESTs, agrupadas en 9 unigenes, que codifican enzimas de cítricos potencialmente implicadas en la biosíntesis de giberelinas. Dos unigenes de cítricos (aC08014B02 y aC18022B11) mostraron similitud de secuencia con CPS, cuatro unigenes (aC08012B11, aKNOAAL1BE10, aKN0AAP12YO22, aCL8938Contig1) con KAO, un unigen (aCL8642Contig1) con GA20ox y dos unigenes con GA2ox (aC08003D01 y aC18016F11) (Tabla 17).

\begin{tabular}{llcrr}
\hline Tabla 17. Unigenes de cítricos que codifican enzimas del metabolismo de giberelinas \\
\hline \multicolumn{1}{c}{ Enzimas } & $\begin{array}{c}\text { Unigen } \\
\text { de cítricos }\end{array}$ & $\begin{array}{c}\text { Gen de ATH } \\
\text { más similar }\end{array}$ & Valor $E$ & $\begin{array}{r}\text { No }^{\circ} \text { total } \\
\text { ESTs }\end{array}$ \\
\hline Copalil difosfato sintasa (CPS) & aC08014B02 & At4g02780 & $1 \mathrm{E}-39$ & 1 \\
& aC18022B11 & At4g02780 & $5 \mathrm{E}-27$ & 1 \\
Ácido ent-kaurenoico oxidasa & aC08012B11 & At1g05160 & $4 \mathrm{E}-56$ & 1 \\
(KAO) & aKN0AAL1BE10 & At2g32440 & $5 \mathrm{E}-73$ & 1 \\
& aKN0AAP12YO22 & At2g32440 & $2 \mathrm{E}-48$ & 1 \\
& aCL8938Contig1 & At2g32440 & $1 \mathrm{E}-119$ & 2 \\
Giberelina 20-oxidasa (GA20ox) & aCL8642Contig1 & At4g25420 & $1 \mathrm{E}-148$ & 2 \\
Giberelina 2-oxidasa (GA2ox) & aC08003D01 & At1g30040 & $6 \mathrm{E}-49$ & 1 \\
& aC18016F11 & At1g30040 & $6 \mathrm{E}-13$ & 1 \\
\hline
\end{tabular}

La colección de ESTs del CFGP consta de 85,965 ESTs generadas a partir de 52 genotecas de cDNA que cubren un amplio rango de tejidos, estadios de desarrollo y condiciones de estrés biótico y abiótico. Sin embargo, la proporción de ESTs relacionadas con el metabolismo de GAs es realmente baja (0.12 \%) lo que indica que el nivel de expresión de estos genes en el amplio rango de condiciones estudiadas es bajo. Aunque el número de ESTs relacionadas con la biosíntesis de GAs no es suficiente para analizar la expresión génica según la frecuencia de ESTs, resulta interesante destacar que 8 de las 11 ESTs (73\%) identificadas proceden de tres genotecas de cDNA generadas a partir de las raíces lo que puede indicar que, en cítricos, las raíces son órganos fundamentales en la síntesis de giberelinas. 


\subsection{Biosíntesis de flavonoides}

Los cítricos acumulan grandes cantidades de flavonoides, tanto en los frutos como en las hojas, especialmente flavanonas. La biosíntesis de flavanonas se produce en dos pasos: el primero, catalizado por chalcona sintasa (CHS, EC 2.3.1.74; 10 unigenes), consiste en la condensación de 4-cumaroil-CoA con tres moléculas de malonil-CoA para formar naringenina-chalcona, y el segundo, mediado por chalcona isomerasa ( $\mathrm{CHI}$, EC 5.5.1.6; 5 unigenes), conduce a la formación de naringenina (Fig. 24). En el conjunto de ESTs de cítricos del CFGP se identificaron 119 ESTs con elevada similitud de secuencia a CHS previamente caracterizada en Citrus sinensis (Moriguchi et al, 1999) y 12 ESTs similares a CHI de Citrus unshiu (Moriguchi et al, 2001) (Tabla 18, Tabla Suplementaria XIII).

\begin{tabular}{lcrrr}
\hline \multicolumn{4}{c}{ Tabla 18. Unigenes de cítricos que codifican enzimas de biosíntesis de flavonoides } \\
\hline \multicolumn{1}{c}{ Enzimas } & EC & Contigs & $\begin{array}{r}\text { Singletons } \\
\text { N }\end{array}$ & $\begin{array}{c}N^{\circ} \text { Total } \\
\text { ESTs }\end{array}$ \\
\hline Chalcona sintasa (CHS) & 2.3 .1 .74 & 5 & 5 & 119 \\
Chalcona isomerasa (CHI) & 5.5 .1 .6 & 2 & 3 & 12 \\
Flavanona 3-hidroxilasa (F3H) & 1.14 .11 .9 & 9 & 7 & 50 \\
Flavona sintasa II (FNS II) & - & 2 & 0 & 8 \\
Flavonoide 3'-hidroxilasa (F3'H) & 1.14 .13 .21 & 5 & 2 & 44 \\
Flavonol sintasa (FLS) & 1.14 .11 .23 & 1 & 3 & 29 \\
Dihidroflavonol 4-reductasae (DFR) & 1.1 .1 .219 & 6 & 2 & 23 \\
\hline
\end{tabular}

En cítricos, la naringenina puede sufrir las siguientes transformaciones:

1) Hidroxilación para formar el flavanol dihidroxikaempferol, reacción catalizada por flavanona 3-hidroxilasa (F3H, EC 1.14.11.9; 16 unigenes) (Fig. 24, Tabla Suplementaria XIII). Un total de 50 ESTs del CFGP mostraron similitud de secuencia con el gen de Citrus unshiu que codifica F3H (Moriguchi et al, 2001).

2) Dos glucosilaciones sucesivas: la primera está catalizada por 7-O-glucosiltransferasa (EC 2.4.1.185) cuya actividad ha sido estudiada en Citrus paradisi (Mclntosh et al, 1990) aunque todavía no se ha aislado el gen correspondiente. La segunda glucosilación está mediada bien por 1-2 rhamnosiltransferasa (EC 2.4.1.236) para formar naringina o bien por 1-6 rhamnosiltransferasa para formar narirutina (Fig. 24). El gen que codifica 1-2 rhamnosiltransferasa ha sido aislado y caracterizado en Citrus maxima (Frydmann et al, 2004) pero no se identificó ninguna EST en el CFGP cuya secuencia fuera similar a este gen. La actividad 1-6 rhamnosiltransferasa se ha descrito en cítricos pero todavía no se ha purificado dicha enzima ni se ha caracterizado el gen correspondiente. 


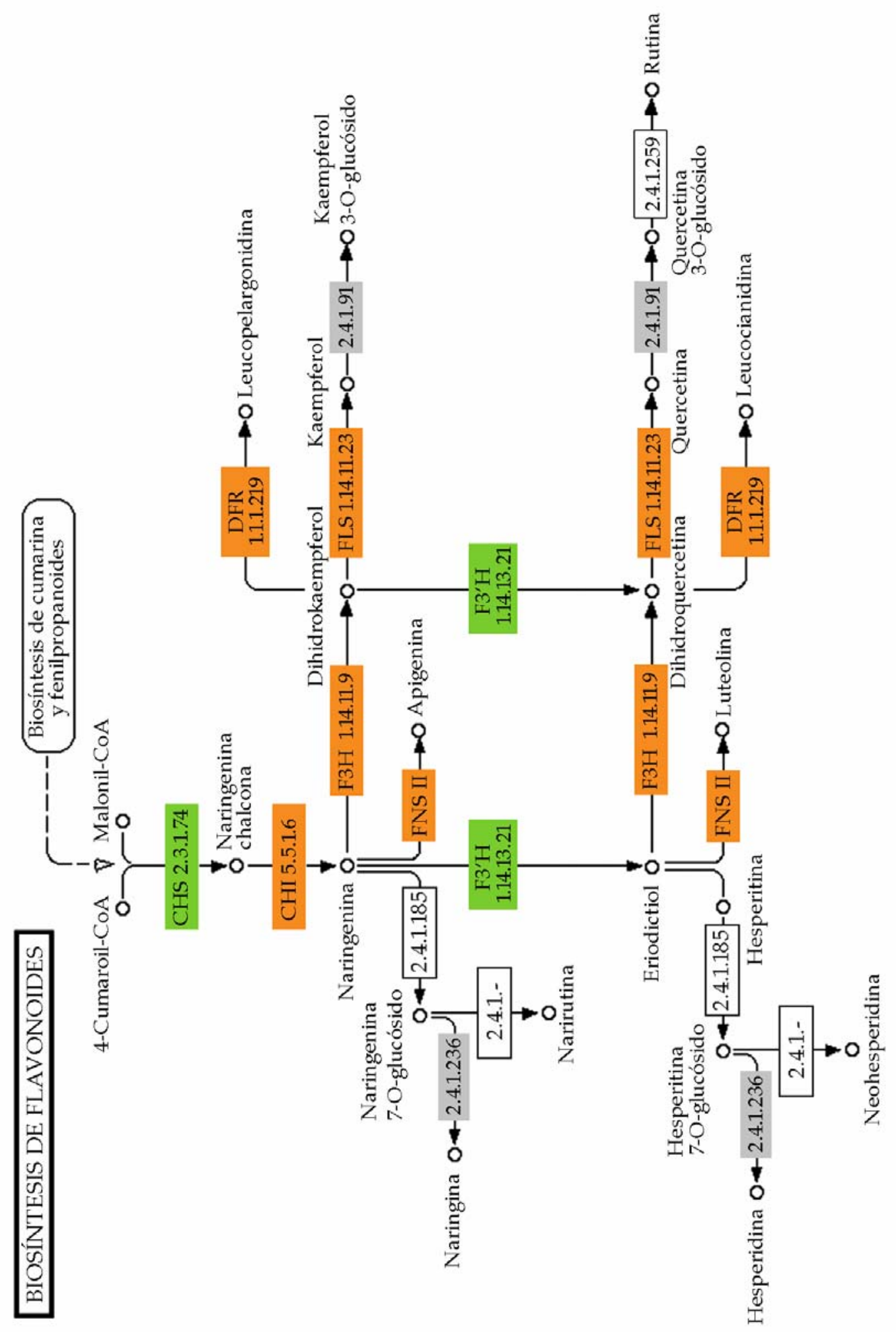

Fig. 24. Biosíntesis de flavonoides en cítricos. Las cajas coloreadas representan los pasos para los que se identificaron unigenes en el conjunto de ESTs del CFGP (en naranja), para los que se encontró algún representante procedente de la genoteca Veg1 (en verde) o para los que ninguna EST de cítricos mostró similitud significativa de secuencia (en gris). Las cajas vacías indican los pasos para los que todavía no se han clonado los genes implicados. 
3) Oxidación para formar la flavona apigenina, catalizada por flavona sintasa II (FNS II). Las plantas superiores han desarrollado dos sistemas independientes para catalizar la síntesis de flavona: flavona sintasa I (FNS I) presente sólo en la familia Apiaceae y flavona sintasa II (FNS II) más extendida en las plantas. El gen que codifica FNS II ha sido aislado y caracterizado en Gerbera (Martens y Forkmann, 1999) y en otras especies vegetales. En cítricos, este paso de la biosíntesis de flavonoides todavía no ha sido caracterizado. En el conjunto de ESTs de cítricos del CFGP se identificaron dos unigenes, aCL2638Contig1 y aCL2638Contig2, cuyas secuencias deducidas de aminoácidos fueron similares a FNS II, 54\% identidad, $76 \%$ similitud y $55 \%$ identidad, $76 \%$ similitud, respectivamente (Tabla 18, Tabla Suplementaria XIII).

4) Hidroxilación para formar eriodictiol, reacción catalizada por flavonoide 3'-hidroxilasa (F3'H, EC 1.14.13.21; 7 unigenes). La actividad enzimática de F3'H ha sido estudiada en cítricos (Doostdar et al, 1995) pero, hasta el momento, no se ha caracterizado el gen de cítricos correspondiente. En la colección de ESTs del CFGP se identificaron 44 ESTs, agrupadas en 7 unigenes, con similitud significativa de secuencia con el gen que codifica F3'H en Arabidopsis (At5g07990) (Tabla 18, Tabla Suplementaria XIII). En la colección de ESTs generada a partir de la genoteca Veg1 se encontró representado este gen. Este resultado es consistente con el hecho de que la actividad enzimática de F3'H de cítricos está presente en hojas jóvenes (Doostdar et al, 1995).

La naringina es la flavanona diglucosilada que más se acumula en frutos y hojas de especies como Citrus paradisi. Sin embargo, en otras especies de cítricos como la objeto de nuestro trabajo, Citrus clementina, la flavanona diglucosilada más abundante es hesperidina (Tabla 19, Kawaii et al, 1999; 2000).

\begin{tabular}{lrrrr}
\hline \multicolumn{5}{c}{ Tabla 19. Contenido en flavonoides en frutos y hojas (tomado de Kawaii et al, 1999, 2000) } \\
\cline { 2 - 5 } \multicolumn{1}{c}{ Especie } & Naringina & Narirutina & Hesperidina & Rutina \\
\hline Frutos & 1459 & 500 & 5 & 0 \\
C. paradisi & 0 & 51.1 & 852 & 0 \\
C. clementina & & & 0 & \\
Hojas & 402 & 80.5 & 763 & 0 \\
C. paradisi & 0 & 0 & 885 \\
C. clementina & & & & \\
\end{tabular}

La hesperidina, análogamente a la naringina, procede de la doble glucosilación de la hesperitina. La biosíntesis de hesperitina no se conoce totalmente pues el paso de eriodictiol a hesperitina todavía no está caracterizado. El eriodictiol puede ser 
oxidado para formar la flavona luteolina o hidroxilado formando el flavanol dihidroquercetina, de forma análoga a la naringenina (Fig. 24). Ambos flavanoles, dihidroxikaempferol y dihidroxiquercetina, son convertidos en los flavonoles kaempferol y quercetina, respectivamente, mediante la acción de flavonol sintasa (FLS, EC 1.14.11.23; 4 unigenes) (Fig. 24). Un total de 29 ESTs de cítricos del CFGP, agrupadas en 4 unigenes, mostraron similitud de secuencia con flavonol sintasa de Citrus unshiu (Moriguchi et al, 2002) (Tabla 18, Tabla Suplementaria XIII). Algunas especies de cítricos, como Citrus clementina, acumulan, especialmente en las hojas, elevadas cantidades de rutina (Tabla 19, Kawaii et al, 1999; 2000). La rutina es un flavonol glucósido con propiedades farmacológicas como antiinflamatorio (Manthey et al, 2001). La conversión de quercetina en rutina se produce en dos pasos (Fig. 24): 1) síntesis de quercetina 3-O-glucósido mediante flavonol 3-O-glucosiltransferasa (EC 2.4.1.91), para la que no se identificó ninguna EST en el CFGP y 2) conversión de 3-O-glucósido en rutina mediante flavonol 3-O-glucósido L-ramnosiltransferasa (EC 2.4.1.259), actividad que ha sido purificada parcialmente en Vigna radiata (Barber, 1962) pero para la que no se ha identificado el correspondiente gen.

La utilización de secuencias de genes implicados en la biosíntesis de flavonoides previamente caracterizados como motores de búsqueda en la base de datos de ESTs de cítricos del CFGP ha permitido caracterizar esta ruta en cítricos. Junto a genes ya descritos en cítricos como los correspondientes a CHS (Moriguchi et al, 1999) y $\mathrm{CHI}$ y $\mathrm{F} 3 \mathrm{H}$ (Moriguchi et al 2001), este trabajo ha permitido identificar, por primera vez en cítricos, los genes potencialmente correspondientes a flavona sintasa II (FNSII) y flavonoide 3'-hidroxilasa (F3'H). La identificación de estos genes constituye el paso inicial para completar nuestro conocimiento actual sobre la síntesis de flavonoides en cítricos. Resulta de especial interés la caracterización de FNSII, enzima clave en la biosíntesis de flavonas, para comprender el papel de este grupo de flavonoides en cítricos. 



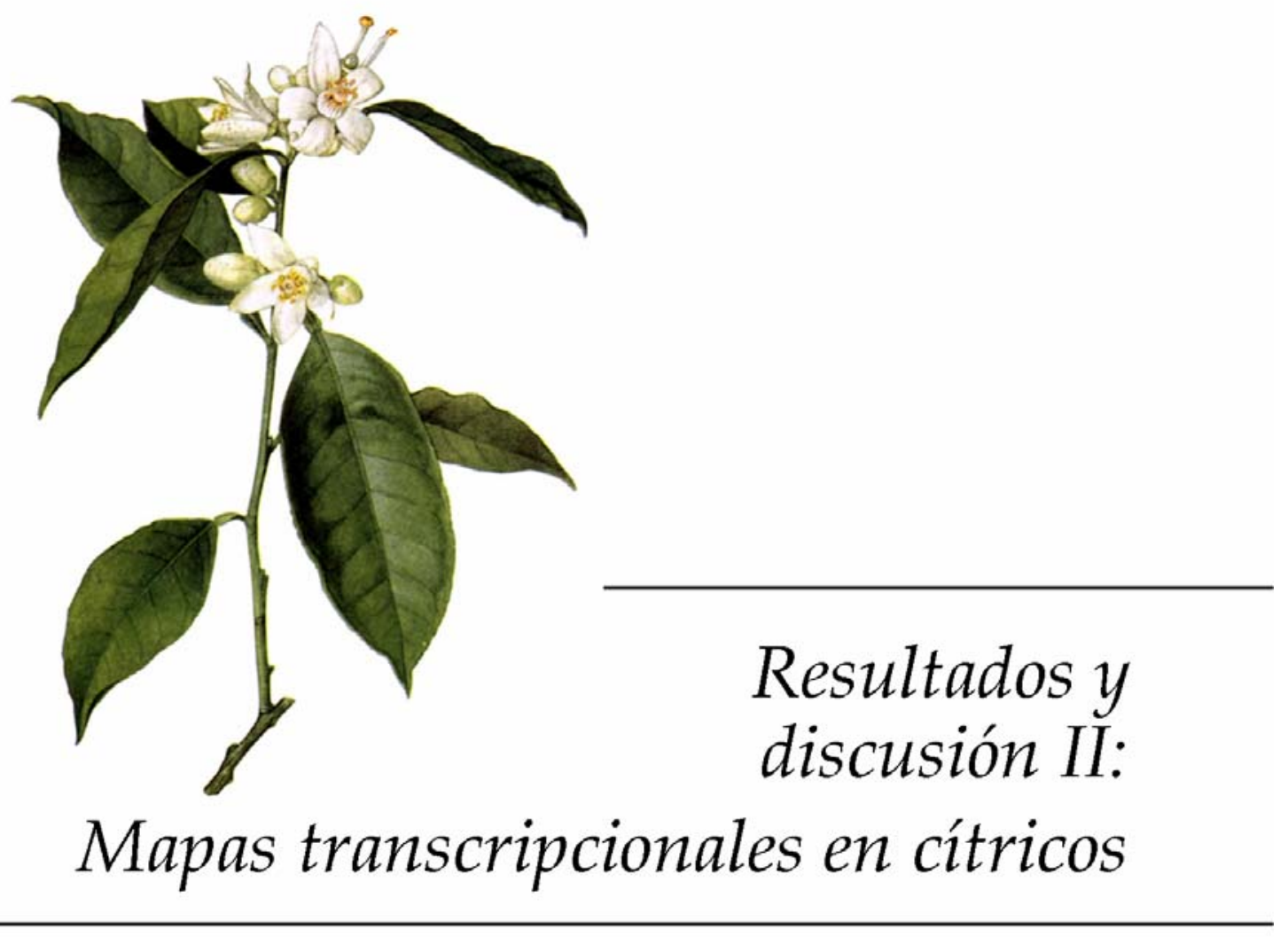





\section{CARACTERIZACIÓN DE LA MICROMATRIZ DE cDNA DE CÍTRICOS, CIT1, GENERADA EN EL CFGP}

\subsection{Caracterización técnica de la micromatriz CIT1}

Los análisis de expresión génica se realizaron utilizando la micromatriz de cDNA de cítricos construida por el Laboratorio de Genómica del CFGP que contiene 12,672 clones que corresponden a 6,875 posibles unigenes (Forment et al, 2005). Tal como se explicó anteriormente, el número de unigenes que resulta de un proceso computacional de agrupamiento o ensamblaje de ESTs varía a medida que el número de ESTs crece. Los 12,672 clones que contiene la micromatriz CIT1 correspondían a 6,875 posibles unigenes cuando la colección de ESTs de cítricos del CFGP contaba con 22,635 ESTs. Actualmente dicha colección contiene 85,965 ESTs, de modo que los 12,672 clones de la micromatriz CIT1 corresponden a 6,034 posibles unigenes. La anotación funcional de los unigenes de cítricos contenidos en la micromatriz CIT1 se recoge en la Tabla Suplementaria XIV. Todos los datos de expresión presentados en este trabajo se obtuvieron utilizando la micromatriz CIT1 y se redefinieron teniendo en cuenta los resultados del último ensamblaje realizado en el CFGP.

Los 12,672 clones contenidos en la micromatriz proceden de 18 genotecas de cDNA (ver Tabla 1 en Materiales y Métodos), entre ellas Veg1. De los 1,824 clones obtenidos a partir de la genoteca Veg1, un total de 1,152 clones fueron incluidos en la micromatriz CIT1 (9.1\%) (Tabla Suplementaria XV). El análisis de los productos de PCR mostró que un $90 \%$ de los 1,152 clones de la genoteca Veg1 incluidos en la micromatriz CIT1 producían una sola banda en la reacción de PCR (Tabla Suplementaria III). Una proporción elevada de los 6,034 posibles unigenes contenidos en la micromatriz CIT1 fueron impresos entre 2 y 5 veces, lo que permitió la confirmación intra-array de los datos de expresión. Por otro lado, alrededor de 4,600 unigenes estaban representados sólo una vez en la micromatriz CIT1.

Con objeto de valorar la fiabilidad de los datos generados utilizando la micromatriz CIT1 se llevó a cabo una caracterización técnica de la misma. Para ello, se realizaron 8 réplicas técnicas utilizando hojas jóvenes procedentes de plantas de invernadero de Citrus clementina. En cada una de las réplicas se extrajo el poli $\left(\mathrm{A}^{+}\right)$ RNA y se marcó con el compuesto fluorescente Cy5. El diseño del experimento consistió en la hibridación de cada una de las réplicas técnicas con una muestra de referencia, marcada con el compuesto fluorescente Cy3, formada por hojas procedentes de 40 plantas. Las hibridaciones se realizaron con micromatrices procedentes de un mismo lote. Los puntos que mostraron una intensidad neta menor a 
dos veces el valor medio del fondo en los dos canales no se consideraron en los análisis posteriores. Los controles negativos siempre se encontraron en este grupo (Tabla Suplementaria XVI). Los datos de expresión se normalizaron utilizando la función Lowess que corrige la dependencia sistemática según la intensidad (Yang et al, 2002; apartado 6.5 de Materiales y Métodos). La Figura 25 muestra los diagramas de caja (box plot) del logaritmo en base dos de los cocientes de expresión tras la normalización de los datos con la función Lowess (Yang et al, 2002; apartado 6.5 de Materiales y Métodos) para cada una de las ocho réplicas técnicas. Los diagramas de caja mostraron una amplitud o dispersión homogénea de los datos en todas las réplicas, lo que refleja una buena reproducibilidad entre éstas.

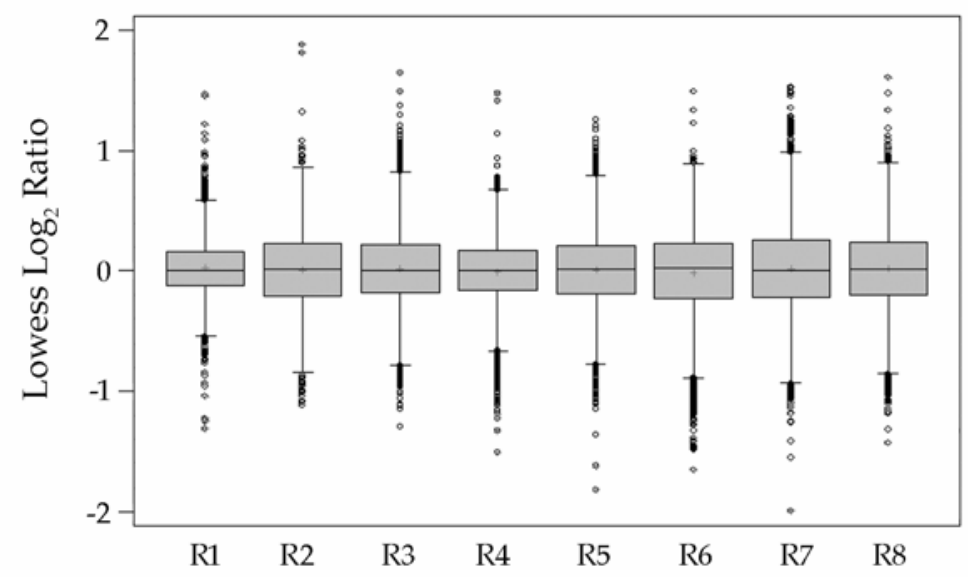

Fig. 25. Diagramas de caja de los datos de expresión. Para cada una de las réplicas técnicas (R1 a R8) se representan los valores correspondientes al logaritmo en base dos de los cocientes de expresión (Cy5/Cy3) tras la normalización de los datos con la función Lowess (Yang et al, 2002).

\subsubsection{Rango dinámico y niveles de sensibilidad}

El rango dinámico y los niveles de sensibilidad se determinaron utilizando los controles depositados en la micromatriz CIT1 (apartado 6.6.2 de Materiales y Métodos). Aunque en algunos casos fue posible detectar intensidades correspondientes al control de calibración 7 , es decir 15 pg de mRNA (Tabla 3 en Materiales y Métodos), se obtuvieron resultados reproducibles cuando se incluyeron, al menos, 50 pg mRNA en las muestras (Tabla Suplementaria XVI), lo que representa alrededor de 10 copias de mRNA por célula (Ruan et al, 1998). El rango de intensidades detectadas de modo consistente fue de 200 a 50,000, lo que corresponde a un rango dinámico de 2.5 órdenes de magnitud. 


\subsubsection{Reproducibilidad intra-array}

La reproducibilidad intra-array, es decir, la reproducibilidad de los datos procedentes de elementos depositados más de una vez en una micromatriz, se estimó, en primer lugar, comparando los niveles de intensidad y los cocientes de expresión de los controles distribuidos en la micromatriz. Los valores de los cocientes de expresión Cy5/Cy3 fueron bastante consistentes, de modo que, para la mayoría de los controles, los valores del coeficiente de variación (CV) no superaron el 14\% (Tabla 20, Tabla Suplementaria XVI).

\begin{tabular}{|c|c|c|c|c|c|c|c|c|}
\hline & Réplica1 & Réplica2 & Réplica3 & Réplica4 & Réplica5 & Réplica6 & Réplica7 & Réplica8 \\
\hline Control Ratio 1 & 0.20 & 0.15 & 0.13 & 0.13 & 0.14 & 0.12 & 0.08 & 0.12 \\
\hline Control Ratio 2 & 0.09 & 0.10 & 0.15 & 0.11 & 0.12 & 0.17 & 0.15 & 0.12 \\
\hline Control Ratio 3 & 0.09 & 0.14 & 0.13 & 0.20 & 0.14 & 0.11 & 0.09 & 0.09 \\
\hline Control Ratio 4 & 0.09 & 0.11 & 0.12 & 0.16 & 0.11 & 0.17 & 0.08 & 0.09 \\
\hline
\end{tabular}

El análisis de los valores de expresión de distintos clones de un mismo contig permitió obtener otra estimación de la reproducibilidad intra-array. Para ello se evaluaron 10 unigenes, seleccionados al azar, representados en la micromatriz CIT1 por 3, 4 ó 5 clones (Tabla Suplementaria XVII). Este análisis también se basó en la agrupación de las ESTs de la colección según el último ensamblaje realizado en el CFGP, de modo que los resultados que se presentan difieren sensiblemente de los obtenidos por Forment et al (2005). Para cada una de las 8 réplicas técnicas realizadas se calcularon los coeficientes de variación de los cocientes de expresión correspondientes a cada uno de los 10 unigenes estudiados (Tabla Suplementaria XVII). Los coeficientes de variación calculados oscilaron entre el $5 \%$ y el $16 \%$, y la mayoría de ellos no superaron el 13\% (Tabla Suplementaria XVII). La Figura 26 muestra los valores de los cocientes de expresión (Сy5/Cy3) obtenidos para 6 de los unigenes estudiados (aCL920Contig2 y aCL2162Contig1, representados por 3 clones en CIT1; aCL2738Contig1 y aCL436Contig1, por 4 clones; y aCL217Contig1 y aCL36Contig2, por 5 clones) en cada una de las 8 repeticiones técnicas realizadas. Los valores de los cocientes de expresión fueron similares para los diferentes miembros de un contig en cada una de las réplicas (Fig. 26). Los unigenes estudiados están representados por clones de diferente longitud y origen, es decir, proceden de diferentes genotecas generadas a partir de diversas condiciones ambientales y de desarrollo. Sin embargo, los resultados obtenidos indican que los niveles de expresión relativos entre las muestras marcadas con Cy5 y con Cy3 fueron consistentes entre los 
miembros del mismo contig independientemente, por tanto, de la longitud y del origen de los clones que representan cada contig.
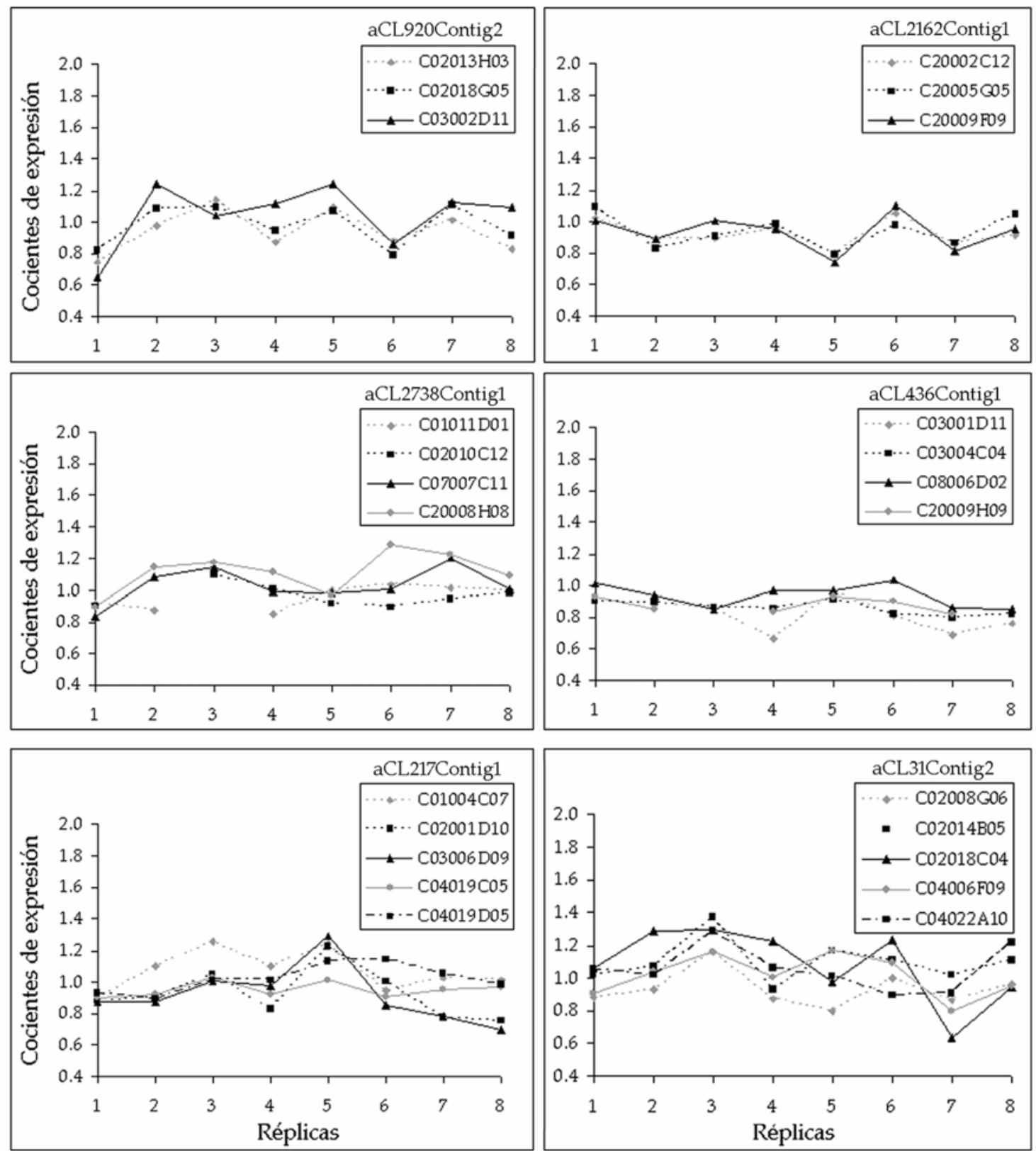

Fig. 26. Representación gráfica de los cocientes de expresión (Cy5/Cy3) correspondientes a cada uno de los clones que representan cada unigen en la micromatriz CIT1, en cada una de las réplicas realizadas. Los unigenes aCL920Contig2 y aCL2162Contig1 codifican, respectivamente, 9-cis-epoxicarotenoide dioxigenasa y beta-ketoacil-CoA sintasa; aCL2738Contig1 y aCL436Contig1 corresponden a la cadena $\beta-1$ de tubulina y aldehido dehidrogenasa y los unigenes aCL217Contig1 y aCL36Contig2 codifican la subunidad $\beta$ de chaperonina de $60 \mathrm{kDa}$ y peroxidasa, respectivamente. 


\subsubsection{Reproducibilidad inter-array}

La reproducibilidad inter-array, es decir, la reproducibilidad de los datos procedentes de un mismo elemento en cada una de las micromatrices, se evaluó comparando los resultados obtenidos en las 8 réplicas técnicas realizadas. La proporción de puntos cuya intensidad neta superó en, al menos, dos veces a la intensidad del fondo fue del $74 \%, 75 \%, 66 \%, 68 \%, 79 \%, 79 \%, 78 \%$ y $70 \%$, para cada una de las ocho réplicas técnicas. Además, se compararon los puntos cuya intensidad neta superaba el criterio establecido en las diferentes micromatrices. Es decir, se calculó cuántos de los puntos $(74 \%)$ que superaron el criterio de intensidad en la réplica $1(\mathrm{R} 1)$ también los superaban en las demás réplicas. Los resultados mostraron que el mismo conjunto de puntos fue consistentemente seleccionado en cada una de las ocho réplicas técnicas (Tabla 21, Tabla Suplementaria XVIII).

\begin{tabular}{|c|c|c|c|c|c|c|c|c|}
\hline \multirow{2}{*}{$\begin{array}{l}\text { Réplicas } \\
\text { técnicas }\end{array}$} & \multicolumn{8}{|c|}{ Réplicas técnicas } \\
\hline & R1 & $\mathrm{R} 2$ & R3 & $\mathrm{R} 4$ & R5 & R6 & R7 & R8 \\
\hline $\mathrm{R} 1$ & - & 92 & 82 & 84 & 94 & 91 & 93 & 85 \\
\hline R2 & 91 & - & 85 & 86 & 95 & 92 & 95 & 89 \\
\hline R3 & 92 & 96 & - & 92 & 95 & 93 & 97 & 93 \\
\hline R4 & 91 & 94 & 90 & - & 94 & 93 & 96 & 90 \\
\hline R5 & 88 & 90 & 79 & 81 & - & 90 & 92 & 84 \\
\hline R6 & 85 & 87 & 78 & 80 & 91 & - & 91 & 83 \\
\hline R7 & 87 & 91 & 82 & 83 & 93 & 92 & - & 87 \\
\hline $\mathrm{R} 8$ & 90 & 95 & 88 & 88 & 96 & 94 & 98 & - \\
\hline
\end{tabular}

Adicionalmente, la reproducibilidad inter-array se determinó mediante el cálculo del coeficiente de variación de los cocientes de expresión obtenidos, para cada uno de los puntos de la micromatriz CIT1, en las ocho réplicas técnicas (Tabla Suplementaria XIX). La representación gráfica de la distribución de frecuencias del coeficiente de variación mostró que, para la mayoría de los puntos, el coeficiente de variación fue del $8-15 \%$, con un valor promedio del $14 \%$, de modo que el $86 \%$ de puntos mostró un coeficiente inferior al 20\% (Tabla Suplementaria XIX, Fig. 27A). Finalmente, para cada punto de la micromatriz CIT1 se representaron los valores del coeficiente de variación obtenido en las ocho réplicas frente a la intensidad total, o suma de las intensidades de los dos canales, en función logarítmica (Tabla Suplementaria XIX, Fig. 27B). EI promedio del coeficiente de variación observado fue inferior al 14\% para los puntos con una intensidad total en $\log _{10}$ inferior a 4 , grupo que incluyó el $96 \%$ de los puntos. El coeficiente de variación obtenido a partir de réplicas técnicas utilizando 
micromatrices de cDNA suele ser del 10-12\% (Yue et al, 2001), lo que indica que la plataforma de micromatrices desarrollada en el CFGP permite obtener resultados reproducibles.

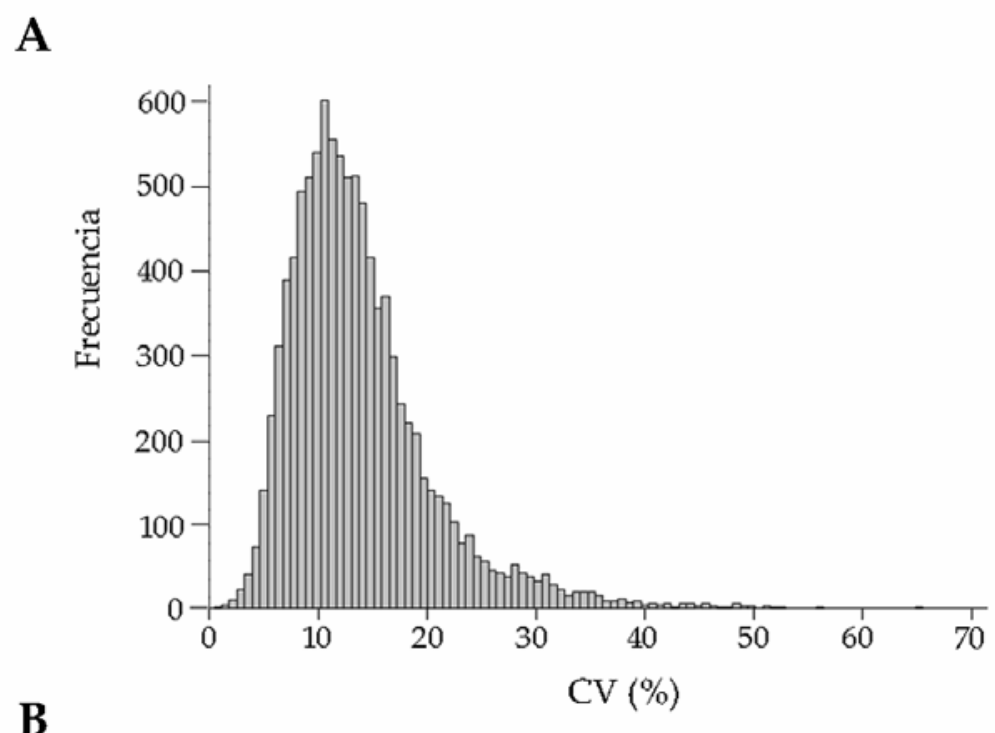

B

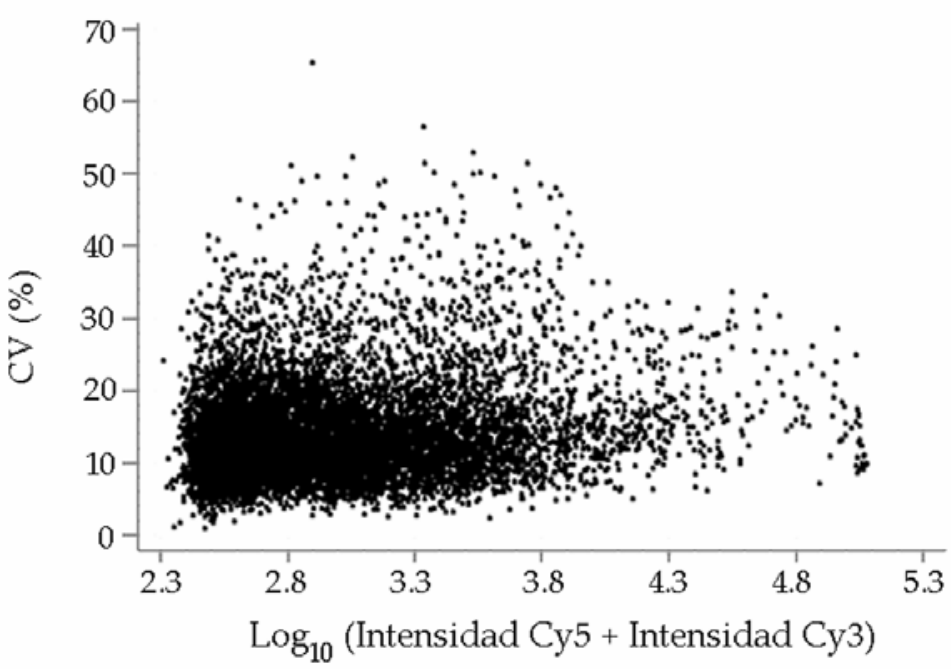

Fig. 27. Coeficiente de variación (CV) de cada uno de los puntos de la micromatriz CIT1 en las ocho réplicas técnicas realizadas. A, Distribución de frecuencias o histograma del coeficiente de variación. $B$, Representación del coeficiente de variación en función de la intensidad total, como $\log _{10}$ (Intensidad Cy5 + Intensidad Cy3).

\subsection{Validación de la micromatriz CIT1 como herramienta para identificar cambios en la expresión génica en cítricos}

El análisis de la expresión génica de hojas y entrenudos procedentes de brotes jóvenes de Citrus clementina se llevó a cabo con un doble objetivo de validar la utilización de la micromatriz CIT1 para identificar cambios en la expresión génica por comparación de los resultados obtenidos con análisis Northern y, por otro lado, como 
un experimento preliminar en la búsqueda de genes expresados diferencialmente en diferentes tejidos en cítricos. Las hojas y los entrenudos se recogieron a partir de brotes vegetativos de Citrus clementina en dos estadios del desarrollo vegetativo: estadio 1, con hojas de 1-2 cm y estadio 5, con hojas de 6-8 cm (Fig. 28A). EI RNA total procedente de las hojas de brotes en el estadio 1 y en el estadio 5 se mezcló a partes iguales y se comparó con el RNA total procedente de los entrenudos, obtenido del mismo modo. El diseño del experimento de micromatrices consistió en cuatro comparaciones directas, dos de ellas con marcaje reverso (Fig. 28B).

A

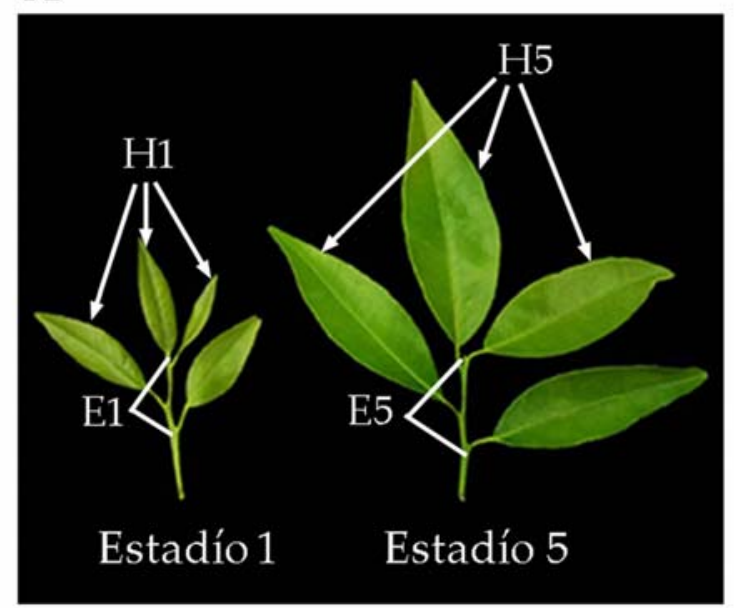

B

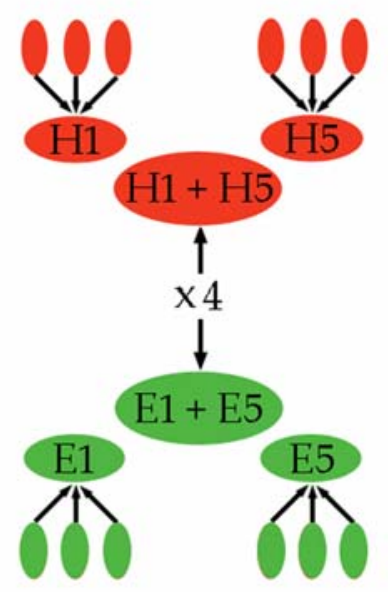

Fig. 28. Análisis de la expresión génica de hojas y entrenudos de brotes vegetativos de Citrus clementina. A, Los brotes vegetativos estudiados corresponden a dos estadios del desarrollo vegetativo diferentes: estadio 1 , brotes con hojas de $1-2 \mathrm{~cm}$ y estadio 5 , brotes con hojas de 6-8 cm. Las muestras de cada estadio proceden de, al menos, tres brotes vegetativos. $B$, El RNA total de las hojas de los brotes del estadio 1 y del estadio 5 se mezcló a partes iguales y se comparó con el RNA de entrenudos de los brotes del estadio 1 y del estadio 5 mezclado, asimismo, a partes iguales. Se realizaron cuatro hibridaciones, dos de ellas con marcaje reverso, es decir, las muestras marcadas con Cy5 se marcan con Cy3 en la hibridación reversa.

Los genes expresados diferencialmente en hojas o en entrenudos se identificaron mediante el análisis estadístico SAM (Significance Analysis of Microarrays) (Tusher et al, 2001) aplicando un criterio para delta de modo que el valor de FDR fuera menor al $5 \%(\Delta=0.337)$. De este modo se identificaron un total de 696 clones con cambios significativos en su expresión (Fig. 29; Tabla Suplementaria XX). Además de cumplir este criterio, los genes expresados diferencialmente se definieron como aquéllos cuyo valor de cambio de expresión fue de, al menos, 1.6 veces $\left(\mid \log _{2}\right.$ (Сy5/Cy3) $\mid \geq 0.678)$. Estas condiciones permitieron identificar un total de 262 unigenes diferencialmente expresados $(4.3 \%$ del total de unigenes de la micromatriz CIT1). De ellos, 159 unigenes estaban expresados diferencialmente en hojas y 103 unigenes se encontraron expresados diferencialmente en entrenudos (Tabla Suplementaria XX). 


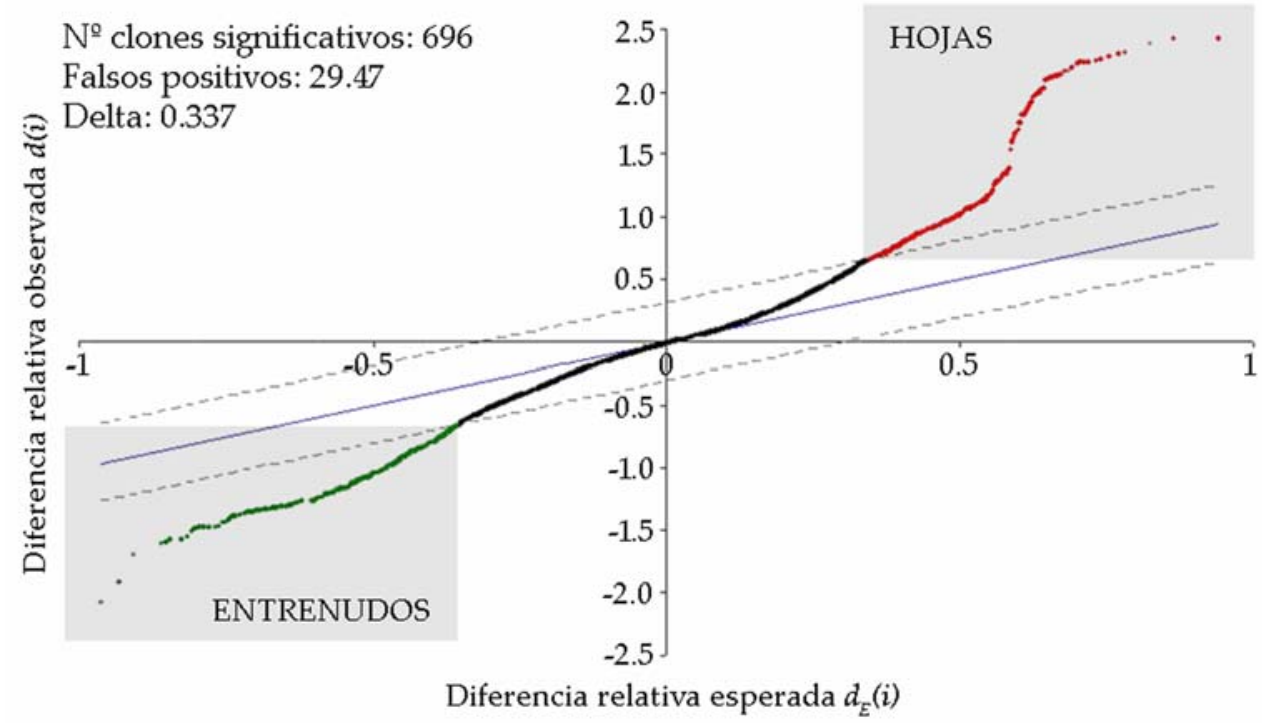

Fig. 29. Identificación de los clones con cambios significativos en su expresión mediante el análisis SAM. El gráfico representa las diferencias relativas observadas $d(i)$ frente a las diferencias relativas esperadas $d_{E}(i)$. La línea sólida indica la línea $d(i)=d_{E}(i)$ en la que las diferencias relativas observadas son idénticas a las diferencias relativas esperadas. Las líneas punteadas se encuentran a una distancia $\Delta=0.337$ de modo que los puntos que se encuentran fuera de esta franja corresponden a clones expresados diferencialmente con un FDR $<5 \%$.

La anotación funcional de los unigenes expresados diferencialmente (Tabla Suplementaria $X X)$ se desarrolló mediante el análisis de la similitud de dichas secuencias, tal como se describe en el apartado 4.3 de Materiales y Métodos. En el siguiente apartado de este capítulo se presentan los resultados obtenidos en la caracterización de diversos tejidos de cítricos mediante el análisis global de la expresión génica. Dado que en el diseño de dicho experimento se incluyeron los tejidos vegetativos comparados en este experimento preliminar (hojas y entrenudos) junto a otros tejidos de cítricos (como raíces y tejidos reproductivos), la interpretación funcional de los resultados obtenidos en ambos experimentos de expresión génica se realizará conjuntamente más adelante (apartado 2.5).

Los datos de expresión génica obtenidos, en la comparación hojas-entrenudos, utilizando la micromatriz de cDNA de cítricos, CIT1, se confirmaron mediante el análisis Northern de seis de los unigenes de cítricos diferencialmente expresados. Se seleccionaron tres unigenes diferencialmente expresados en hojas: aCL11Contig1 (proteína relacionada con lectina), aCL1819Contig1 (fosfoetanolamina $\mathrm{N}$-metiltransferasa) y aC20003A04 (unigen sin proteína similar en las bases de datos consultadas; ver aparado 4.3 de Materiales y Métodos) y tres unigenes diferencialmente expresados en entrenudos: aCL8Contig9 (unigen sin proteína similar), aCL3307Contig1 (xiloglucano:xiloglucosil transferasa) y aCL7Contig6 (metalotioneina). En el análisis Northern se incluyeron los mismos tejidos (hojas y 
entrenudos) en los mismos estadios de desarrollo (estadio 1 y 5), pero además se añadieron hojas y entrenudos procedentes de los estadios de desarrollo intermedios (estadios 2, 3, 4; ver apartado 1.2 de Materiales y Métodos) junto al peciolo y el nervio central de hojas procedentes del estadio de desarrollo 5. Los seis unigenes de cítricos analizados mostraron patrones de expresión similares a los obtenidos utilizando la micromatriz CIT1 (Fig. 30), de modo que la expresión de los unigenes aCL11Contig1, aCL1819Contig1 y aC20003A04 fue claramente superior en hojas y la de los unigenes aCL8Contig9, aCL3307Contig1 y aCL7Contig6 en entrenudos (Fig. 30). La confirmación cualitativa de los patrones de expresión obtenidos mediante análisis Northern indica que los datos de expresión obtenidos utilizando la micromatriz CIT1 son consistentes.

E1 E2 E3 E4 E5 H1 H2 H3 H4 H5 N5 P5

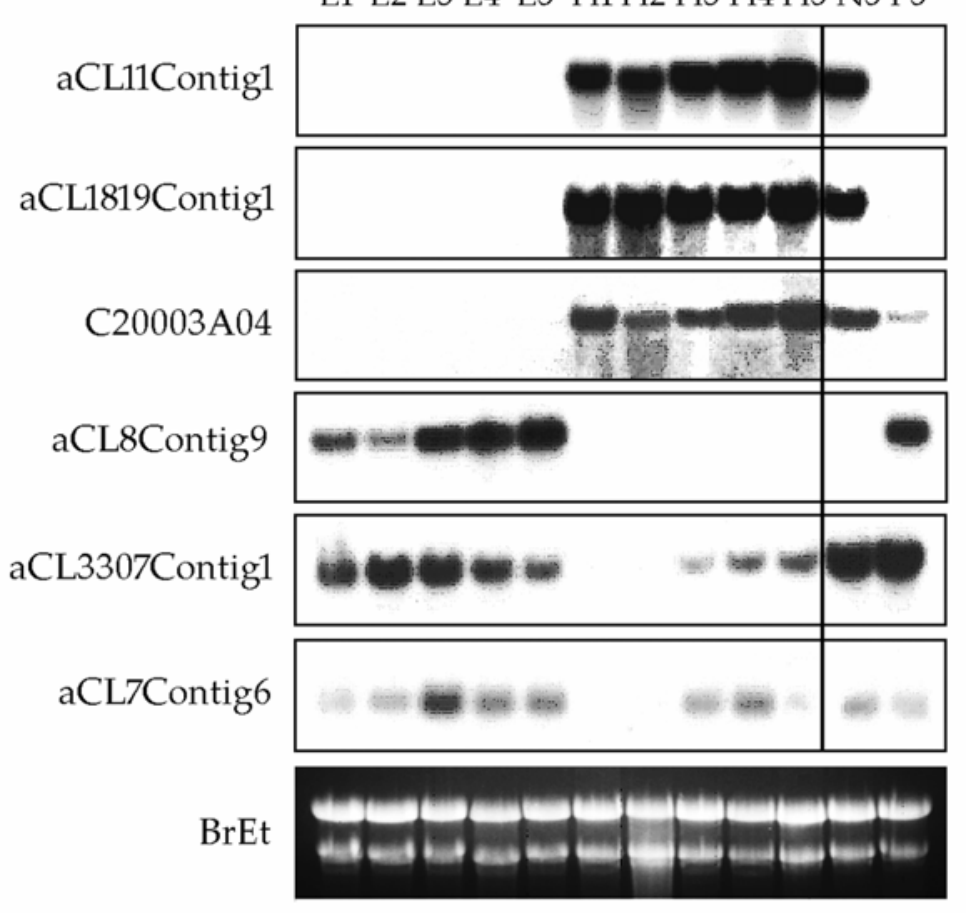

Fig. 30. Análisis Northern de los niveles de expresión de tres unigenes de cítricos diferencialmentes expresados en hojas $(\mathrm{H})$ : aCL11Contig1 (proteína relacionada con lectina), aCL1819Contig1 (fosfoetanolamina N-metiltransferasa) y aC20003A04 (unigen sin proteína similar) y tres unigenes diferencialmente expresados en entrenudos (E): aCL8Contig9 (unigen sin proteína similar), aCL3307Contig1 (xiloglucano:xiloglucosil transferasa) y aCL7Contig6 (metalotioneina) procedentes de brotes vegetativos de Citrus clementina en cinco estadios del desarrollo (apartado 1.2 de Materiales y Métodos). La tinción con bromuro de etidio (BrEt) se utilizó como control de carga. 


\section{CARACTERIZACIÓN DE DIVERSOS TEJIDOS DE CÍTRICOS MEDIANTE EL ANÁLISIS GLOBAL DE LA EXPRESIÓN GÉNICA}

\subsection{Identificación de los genes comúnmente expresados en diversos tejidos de cítricos}

Durante el ciclo de vida de las plantas se forman órganos vegetativos, como raíces, tallos y hojas, así como órganos reproductivos, como flores, frutos y semillas, de modo que cada órgano está especializado en llevar a cabo funciones biológicas concretas. En este trabajo, se estudiaron los patrones de expresión génica de diferentes órganos o tipos de tejidos en cítricos, utilizando la micromatriz CIT1. Para ello se seleccionaron muestras procedentes de diferentes tejidos vegetativos: raíces $(\mathrm{RA})$, lámina foliar (LA), nervio central (NE) y peciolo (PE) de la hoja y entrenudos (EN) de brotes vegetativos en desarrollo; así como muestras procedentes de diferentes tejidos reproductivos: flores en los estadios de desarrollo de botón blanco, bola hueca y antesis y frutos con y sin estilo de Citrus clementina (Fig. 31A). Dado que el objetivo general de este trabajo fue la caracterización en detalle del desarrollo vegetativo en cítricos, el diseño del experimento de micromatrices consistió en la comparación directa de RNA procedente de cada uno de los tejidos vegetativos descritos frente a una mezcla, a partes iguales, de RNA procedente de cada uno de los tejidos reproductivos. Se realizaron tres réplicas biológicas (Fig. 31B).

A
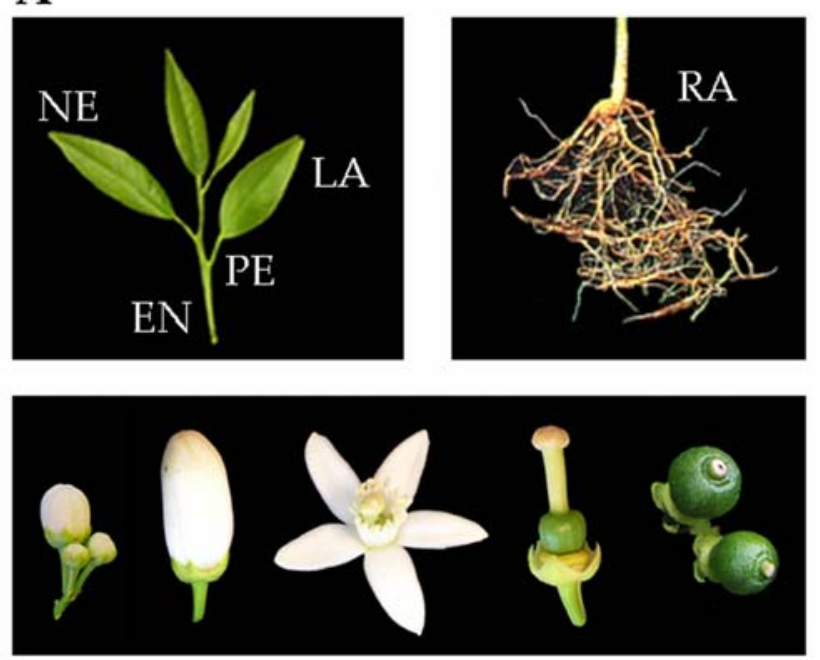

B

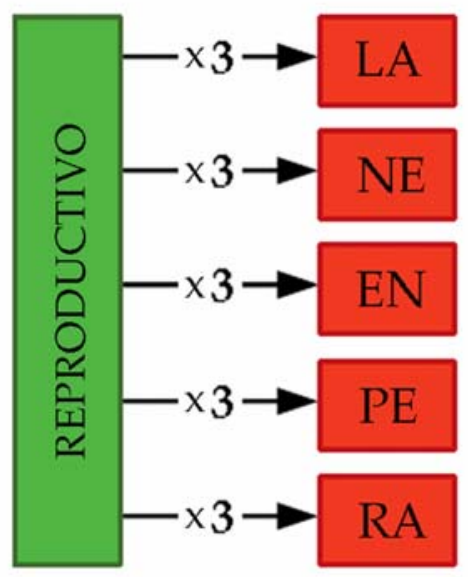

Fig. 31. Diseño del experimento de micromatrices. A, Tejidos vegetativos: raíces (RA), lámina foliar (LA), nervio central (NE) y peciolo (PE) de la hoja y entrenudos (EN) y tejidos reproductivos: flores en diferentes estadios de desarrollo de Citrus clementina, utilizados en los experimentos con micromatrices. B, EI RNA procedente de cada uno de los tejidos vegetativos se marcó con Cy5 y se comparó con una mezcla de RNA procedente de todos los tejidos reproductivos marcado con Cy3. Se realizaron tres réplicas biológicas para cada tejido. 
El número de unigenes de cítricos detectado en los diferentes tejidos estudiados fue similar, desde un $72 \%$ a un $84 \%$ de los clones de cDNA de la micromatriz CIT1. El número similar de mRNAs encontrado en cada muestra refleja un gran solapamiento en los transcritos presentes en los diferentes tejidos. Con objeto de estimar cuántos unigenes de cítricos presentan una expresión similar en todos los tejidos estudiados se determinó el subconjunto de unigenes cuyos valores de expresión se encontraban comprendidos entre -1.6 y $1.6\left(\mid \log _{2}(\right.$ Сy5/Cy3) $\mid \leq 0.678)$ en las 15 comparaciones realizadas. Un total de 2,725 unigenes $(45 \%$ de los contenidos en la micromatriz CIT1) mostraron niveles de expresión similares en los distintos tejidos estudiados (Tabla Suplementaria XXI). El análisis de enriquecimiento funcional, realizado con el programa FatiGO (Al-Shahrour et al, 2004), de los 2,725 unigenes comúnmente expresados en los distintos tejidos estudiados respecto al conjunto de los unigenes de cítricos representados en la micromatriz CIT1 mostró una sobrerepresentación de los genes que codifican proteínas implicadas en los procesos de 'traducción' y de 'biogénesis y ensamblaje de ribosomas' (Fig. 32). Este grupo de unigenes comúnmente expresados parece ser esencial para los procesos celulares fundamentales y podría considerarse como genes housekeeping en cítricos.

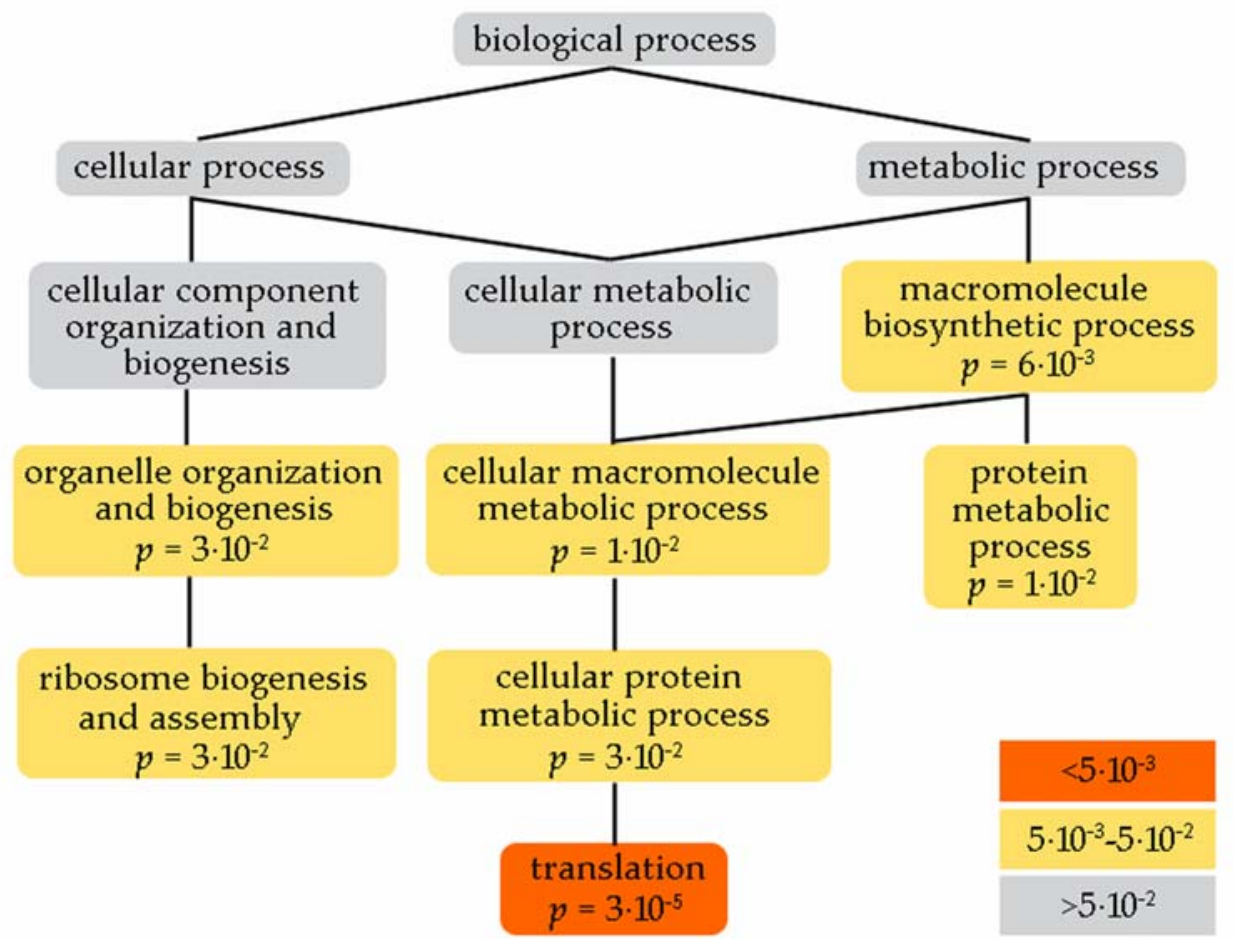

Fig. 32. Ontologías génicas de la componente 'proceso biológico' sobre-representadas en el conjunto de unigenes comúnmente expresados en los distintos tejidos analizados. La escala de color muestra el nivel de significatividad, considerando ontologías enriquecidas aquéllas cuyo valor $p$ corregido es inferior a 0.05 . 


\subsection{Relación entre los tejidos estudiados según los perfiles de expresión génica}

Los valores de expresión obtenidos para cada gen, en cada uno de los 5 tejidos vegetativos estudiados respecto al conjunto de los tejidos reproductivos, se utilizaron para examinar la relación existente entre los patrones de expresión génica en los diferentes tejidos vegetativos mediante el método de agrupamiento jerárquico (Eisen et al, 1998) utilizando el coeficiente de correlación de Pearson y ligamiento completo como parámetros. El subconjunto de los unigenes cuya expresión no cambia substancialmente en ninguno de los tejidos estudiados (ver apartado anterior) se excluyó del análisis para obtener un agrupamiento más robusto. Los algoritmos de agrupamiento jerárquico construyen un árbol o dendrograma que representa la estructura jerárquica de los datos, en este caso en base a los valores de expresión génica, de modo que la longitud de las ramas refleja el grado de similitud entre ellos (Fig. 33).

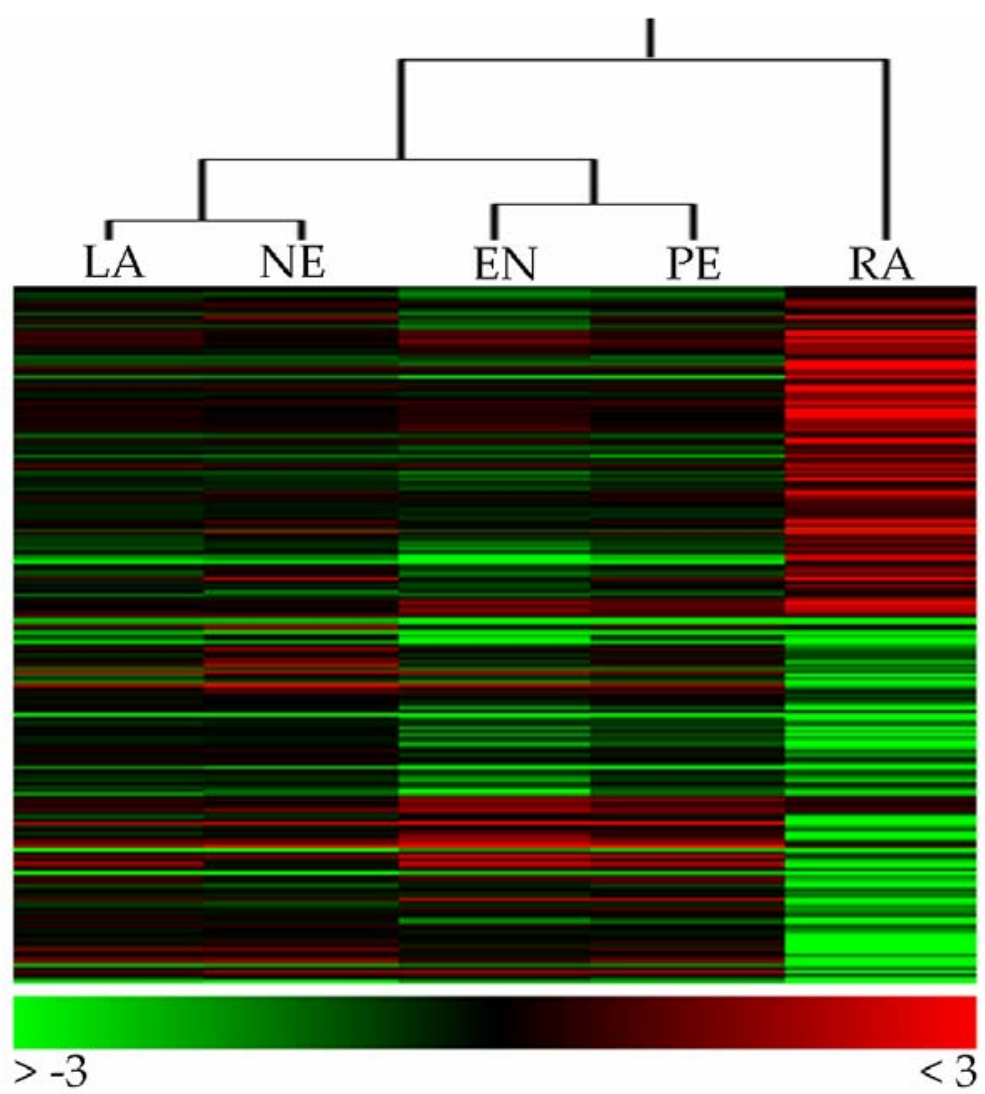

Fig. 33. Relación en los patrones de expresión génica entre los cinco tejidos vegetativos analizados, raíces (RA) y lámina foliar (LA), nervio central (NE) y peciolo (PE) de la hoja y entrenudo (EN) de brotes vegetativos en desarrollo. El agrupamiento jerárquico se realizó y visualizó con el programa Acuity (Axon) utilizando el coeficiente de Pearson y ligamiento completo como parámetros sobre los datos de expresión normalizados por Lowess y expresados en $\log _{2}$. El dendograma refleja la estructura jerárquica de los datos y el mapa de color representa los valores de expresión para cada gen (fila) y en cada uno de los tejidos (columna). 
El análisis de agrupamiento jerárquico mostró que los 4 tejidos vegetativos procedentes de brotes en desarrollo, lámina foliar, nervio central y peciolo de la hoja y entrenudos, tienen patrones de expresión génica similares por lo que quedan agrupados en una rama. En esta rama fue posible distinguir dos subgrupos; el formado por la lámina y el nervio central de la hoja y el formado por el peciolo de la hoja y el entrenudo. Sin embargo, el patrón de expresión génica de las raíces diverge considerablemente del grupo anterior (Fig. 33). Estos resultados indican que los tejidos más relacionados desde el punto de vista morfológico y fisiológico tienen perfiles de expresión génica similares que los distinguen de otros tejidos. Las principales diferencias en los perfiles de expresión génica se encuentran entre la raíz y las partes aéreas y entre los órganos vegetativos y los reproductivos, lo que indica la importancia de la identidad de tejido en la elaboración de los mapas transcripcionales. Finalmente, los resultados obtenidos confirman que la utilización de los datos globales de expresión génica constituye una potente herramienta para inferir jerarquías o relaciones entre los diferentes órganos o tejidos de la planta.

\subsection{Identificación de los genes preferentemente expresados en la raíz}

El diseño del experimento de micromatrices planteado (Fig. 31B) para la identificación de genes de cítricos diferencialmente expresados en los diferentes tejidos estudiados (Fig. 31A) implica que los genes preferentemente expresados en la raíz serán aquellos con expresión diferencial tanto frente al conjunto de los tejidos reproductivos como frente a los diferentes tejidos vegetativos estudiados. La identificación de los genes de cítricos con expresión diferencial en raíz se realizó mediante dos tipos de análisis SAM (Tusher et al, 2001): 1) análisis SAM de una clase para la comparación de la raíz con el conjunto de tejidos reproductivos y 2) análisis SAM de dos clases para la comparación de la raíz con el resto de los tejidos vegetativos, manteniendo un valor de FDR menor al $5 \%$ en ambos casos. Adicionalmente se aplicó un límite de expresión de al menos 1.6 veces de modo que el análisis fue más estricto (ver apartado 6.7 de Materiales y Métodos). En estas condiciones se identificaron un total de 734 unigenes de cítricos (12\% de los unigenes de CIT1) expresados diferencialmente en la raíz (Tabla Suplementaria XXII). De ellos, 622 unigenes (85\% del total de unigenes diferencialmente expresados en raíz) fueron anotados según la función de la proteína de Arabidopsis más similar (Tabla Suplementaria XXII). Con objeto de comprender los procesos biológicos relacionados con los unigenes diferencialmente expresados en la raíz se obtuvo su anotación funcional, basada en GO (Ashburner et al, 2000) (Tabla Suplementaria XXII) y se 
realizó un análisis de enriquecimiento funcional con la herramienta FatiGO (Al-Shahrour et al, 2004). El análisis de enriquecimiento funcional mostró que no existía ninguna ontología génica sobre-representada en ninguno de los tres componentes de 'proceso biológico', 'componente celular' y 'función molecular'. Sin embargo, la anotación GO mostró que la proporción de genes implicados en la respuesta a estrés fue relativamente superior en el conjunto de los genes diferencialmente expresados en la raíz (Tabla 22).

\begin{tabular}{lrr}
\hline Tabla 22. Genes diferencialmente expresados en la raíz implicados en la respuesta a estrés \\
\hline & \multicolumn{1}{c}{ Raíz } & \multicolumn{1}{c}{ CIT1 } \\
\cline { 2 - 3 } Unigenes de cítricos con proteína similar en Arabidopsis & 622 & 4465 \\
Unigenes de cítricos con anotación en 'proceso biológico' & 357 & 1634 \\
& & \\
Respuesta a estrés & $\mathbf{5 0 ( 1 4 \% )}$ & $\mathbf{1 5 0 ( 9 \% )}$ \\
$\quad$ respuesta a estrés osmótico & $10(2.8 \%)$ & $25(1.5 \%)$ \\
$\quad$ respuesta a estrés oxidativo & $14(4 \%)$ & $25(1.5 \%)$ \\
respuesta a estrés salino & $8(2.2 \%)$ & $20(1.2 \%)$ \\
$\quad$ respuesta a estrés hídrico & $11(3 \%)$ & $17(1 \%)$ \\
Respuesta a toxinas & $\mathbf{6 ( 1 . 7 \% )}$ & $\mathbf{6 ( 0 . 4 \% )}$ \\
\hline
\end{tabular}

El conjunto de genes expresados diferencialmente en raíz en respuesta a estrés osmótico o salino incluyó genes que codifican MAP kinasas, implicadas en la transducción de señal por estrés osmótico; genes que codifican proteínas de dedo de zinc y genes correspondientes a factores de transcripción de la familia MYB. Entre los genes de respuesta a estrés oxidativo se encontraron diversas peroxidasas, catalasas y proteínas LEA. En particular, se identificaron diversos unigenes de cítricos similares a la proteína LEA5 (At4g02380) que mostraron una expresión elevada en raíces $\left(\log _{2}>3\right.$; Tabla Suplementaria XXII). En Arabidopsis, la expresión del gen At4g02380 es, asimismo, muy elevada en raíz (Fizames et al, 2004). El grupo de genes de respuesta a estrés hídrico incluyó dos unigenes que codifican acuaporinas o proteínas PIP, implicadas en el transporte de agua a través de las membranas celulares. La secuencia de uno de los unigenes de cítricos presentó una similitud elevada con PIP2.2 (At2g37170). En Arabidopsis, se ha demostrado que el gen PIP2.2 se expresa predominantemente en raíz y que la proteína PIP2B es una de las isoformas PIP más abundantes en la raíz (Javot et al, 2003). El grupo de genes de respuesta a toxinas diferencialmente expresado en raíz incluyó, principalmente unigenes que codifican glutatión S-transferasas (GSTs), que catalizan la conjugación de glutatión con una variedad de sustratos electrofílicos, y están implicadas en la detoxificación tanto de compuestos xenobióticos como de compuestos endógenos tóxicos para las células vegetales. En Arabidopsis, la GST codificada por el gen At2g29420 muestra una mayor expresión en raíces (DeRidder y Goldsbrough, 2006). 
Adicionalmente, el conjunto de unigenes de cítricos expresados diferencialmente en la raíz incluyó genes implicados en el desarrollo de la raíz. La secuencia del unigen aCL503Contig1 es muy similar al gen RHD2 de Arabidopsis (At5g51060), que está implicado en la elongación de las raíces y los pelos radiculares, proceso esencial en la absorción de minerales y agua del suelo. En Arabidopsis, RHD2 se expresa en la epidermis y en la zona de elongación de la raíz y en los pelos radiculares en elongación (Foreman et al, 2003). El unigen aCL8376Contig1 corresponde al gen SOS4 de Arabidopsis (At5g37870), que controla la formación de los pelos radiculares y se expresa en dichas estructuras (Shi y Zhu, 2002). Otros unigenes de cítricos similares a SUR2 (At4g31500), relacionado con la formación de raíces adventicias (Sorin et al, 2006) y PGP1 (At2g36910), que interviene en el transporte de auxinas y se localiza en el ápice de la raíz (Geisler et al, 2005) se encontraron en el conjunto de los unigenes diferencialmente expresados en la raíz.

Los factores de transcripción (TFs) controlan muchos aspectos del desarrollo de las plantas pues especifican cuándo y dónde se expresa un conjunto de genes. Dado que muchos TFs están regulados a nivel de la transcripción, conocer dónde se expresan los genes que codifican TFs resulta de interés para comprender el papel biológico de dichos TFs (Czechowski et al, 2004). La micromatriz CIT1 contiene 197 unigenes de cítricos que codifican TFs, lo que supone un $3 \%$ del total de unigenes representados en CIT1 (Anejo III). En el conjunto de unigenes expresados diferencialmente en raíces de cítricos se identificaron 32 unigenes que codifican TFs (16\% de los representados en CIT1) (Tabla Suplementaria XXIII). En la Figura 34 se muestran los valores de expresión, representados como porcentaje de expresión en cada una de las partes aéreas estudiadas (lámina foliar, nervio central y peciolo de la hoja, entrenudo y conjunto de tejidos reproductivos) respecto a la expresión obtenida en la raíz, para 11 unigenes de cítricos que codifican TFs. Una de las familias más representadas entre los unigenes de cítricos diferencialmente expresados en raíz fue la familia MYB (Fig. 34A). En Arabidopsis, la expresión de la mayoría de los genes MYB aumenta en respuesta a estrés, por ejemplo, At1g72650, At5g67300 y At4g21440 responden a estrés salino (Yanhui et al, 2006). Adicionalmente, se identificaron unigenes diferencialmente expresados en la raíz que codifican TFs pertenecientes a otras familias (Fig. 34B). Hasta donde sabemos, no existen trabajos publicados acerca de la expresión de la mayoría de los genes que codifican los TFs identificados en este trabajo como diferencialmente expresados en raíz (Tabla Suplementaria XXIII). Sin embargo, el hecho de que estos genes se expresen diferencialmente en la raíz en cítricos puede indicar un papel en la regulación del 
desarrollo o de otros procesos específicos de la raíz. Esta información puede constituir la base para el estudio de las funciones de dichos genes.

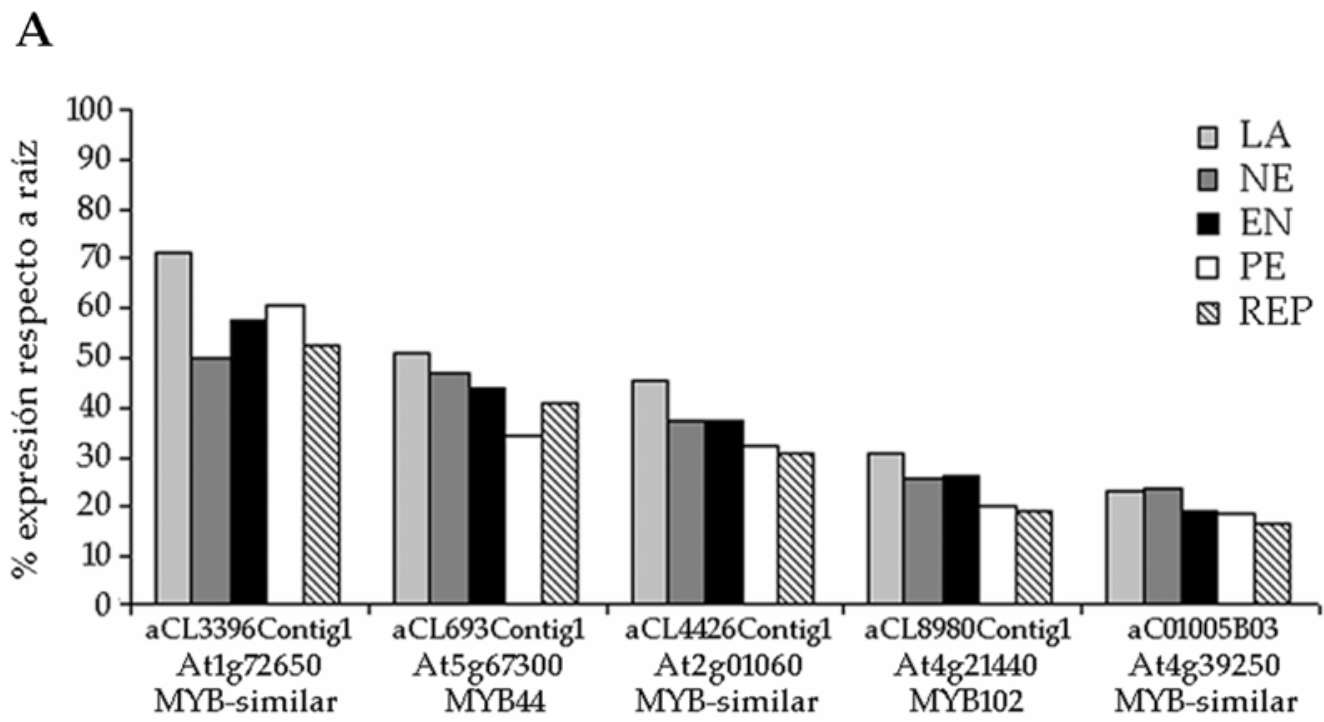

B

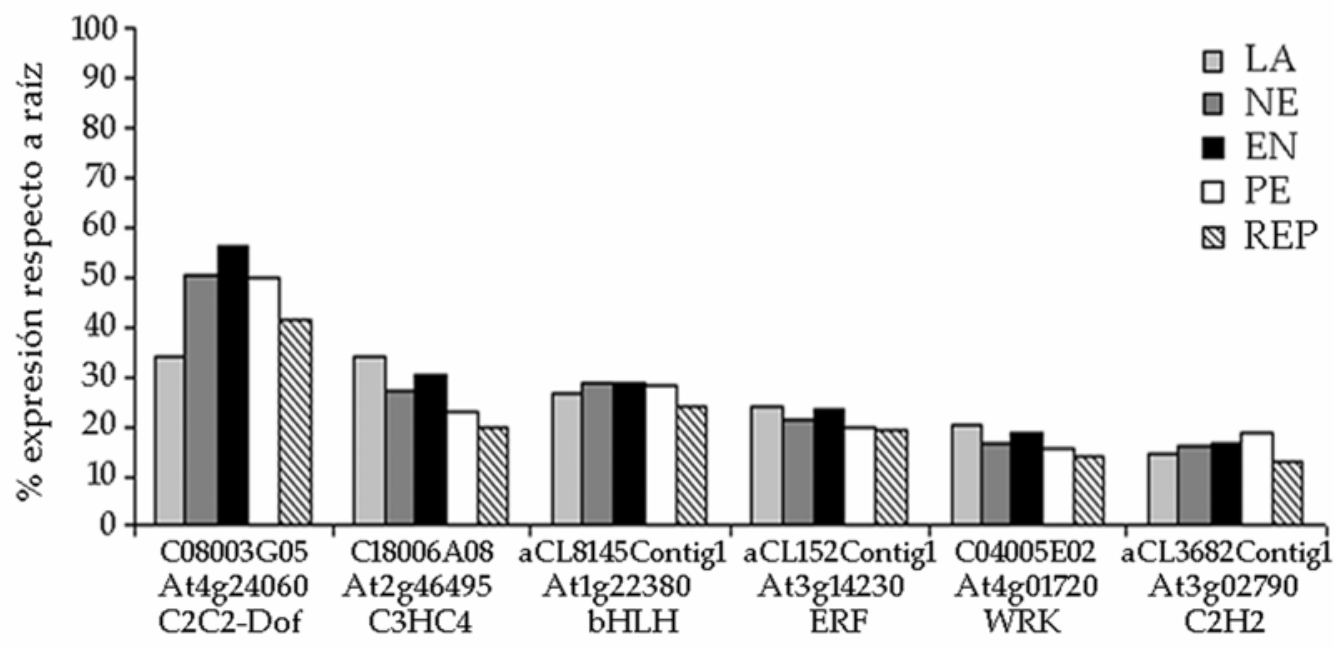

Fig. 34. Porcentaje de expresión en cada una de las partes aéreas estudiadas (lámina foliar, LA; nervio central de la hoja, NE; entrenudo, EN; peciolo, PE y conjunto de tejidos reproductivos, REP) respecto a la expresión obtenida en la raíz para los siguientes genes de cítricos que codifican factores de transcripción de la familia MYB (A) y de las familias C2C2Dof, C3HC4, bHLH, ERF, WRK y C2H2 (B).

\subsection{Identificación de los genes preferentemente expresados en los tejidos reproductivos}

La identificación de los genes diferencialmente expresados en los tejidos reproductivos se llevó a cabo siguiendo la misma metodología descrita en el apartado anterior. Los análisis SAM realizados permitieron identificar un total de 238 unigenes de cítricos (4\% de los unigenes de CIT1) expresados diferencialmente en el conjunto 
de los tejidos reproductivos de cítricos estudiados (Tabla Suplementaria XXIV). EI análisis de enriquecimiento funcional, realizado con el programa FatiGO (Al-Shahrour et al, 2004), de este grupo de genes respecto al conjunto de los unigenes representados en la micromatriz CIT1 mostró que las GO no redundantes de 'desarrollo del carpelo' (GO:0048440, $p=9 \cdot 10^{-3}$ ) 'biosíntesis de ácidos grasos' (GO:0006633, $p=4 \cdot 10^{-2}$ ) y 'transporte de lípidos' (GO:0006869, $p=2 \cdot 10^{-3}$ ) estaban significativamente sobre-representadas en el conjunto de unigenes diferencialmente expresados en los tejidos reproductivos (Fig. 35).

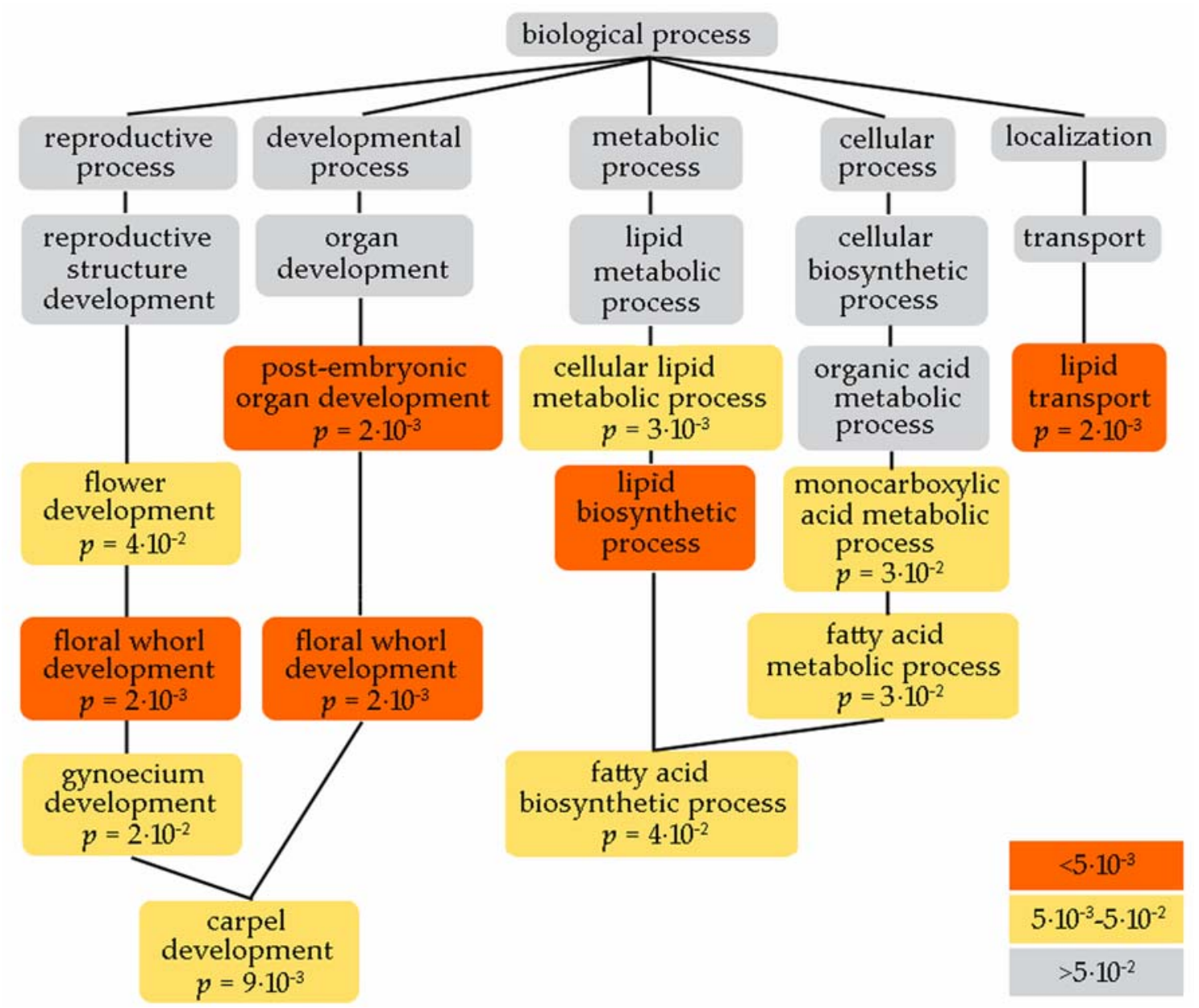

Fig. 35. Ontologías génicas de la componente 'proceso biológico' sobre-representadas en el conjunto de unigenes expresados diferencialmente en los tejidos reproductivos. La escala de color muestra el nivel de significatividad, considerando ontologías enriquecidas aquéllas cuyo valor $p$ corregido es inferior a 0.05 .

Las GO relacionadas con el desarrollo floral (Fig. 35) incluyeron los unigenes de cítricos implicados en especificar la identidad de los órganos florales como agamous (AG, aCL2625Contig1), pistillata ( $P$, aC20007B02), sepallata 3 (SEP3, aCL176Contig1) y los relacionados con el desarrollo del carpelo como shatterproof 1 
(SHP1, aCL4207Contig1) y crabs claw (CRC, C20019G10) (Tabla Suplementaria XXIV). Los patrones de expresión de estos genes en los distintos tejidos estudiados mostraron, como era de esperar, una expresión diferencial en el conjunto de los tejidos reproductivos (Fig. 36). Sin embargo, los patrones de expresión de otros genes implicados en el desarrollo floral (como apetala, leafy, cauliflower o terminal flower 1 , entre otros) no pudieron ser evaluados porque estos genes no se encuentran representados en la micromatriz CIT1.

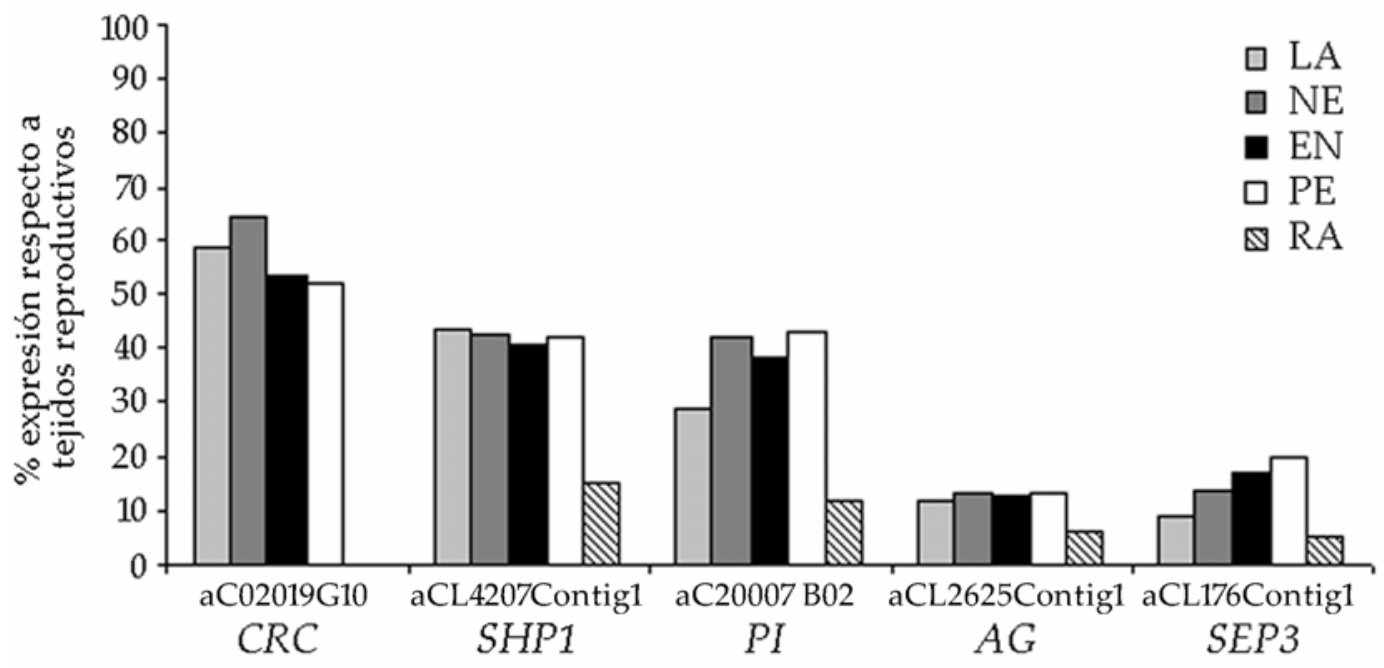

Fig. 36. Porcentaje de expresión en cada uno de los tejidos vegetativos analizados (lámina foliar, NA; nervio central de la hoja, NE; entrenudo, EN; peciolo, PE y raíz, RA) respecto al conjunto de los tejidos reproductivos para los siguientes genes de cítricos implicados en el desarrollo floral: AG (aCL2625Contig1), PI (aC20007B02), SEP3 (aCL176Contig1), SHP1 (aCL4207Contig1) y CRC (C20019G10).

Recientemente, se ha estudiado la expresión de los siguientes genes de cítricos implicados en la floración: leafy, apetala1, terminal flower 1, y diversos homólogos a flowering locus $T$ (Nishikawa et al, 2007). Sin embargo, los genes implicados en especificar la identidad de los órganos florales como agamous, pistillata, sepallata 3 y los relacionados con el desarrollo del carpelo como shatterproof 1 y crabs claw no habían sido identificados previamente en cítricos.

Adicionalmente, el análisis de enriquecimiento funcional mostró que las GO correspondientes a la biosíntesis de ácidos grasos y al transporte de lípidos estaban significativamente sobre-representadas en los tejidos reproductivos (Fig. 35; Tabla Suplementaria XXIV). La ontología génica de biosíntesis de ácidos grasos incluyó los genes CER1, que en Arabidopsis está relacionado con la fertilizadad del polen (Aarts et al, 1995) y JMT, cuya expresión es elevada en flores de Arabidopsis (Seo et al, 2001). La síntesis y el almacenamiento de lípidos son procesos de conocida importancia durante la microsporogénesis y el desarrollo del polen (Ferreira et al, 
1997), lo que resulta coherente con la sobre-representación de los genes implicados en la biosíntesis de ácidos grasos en los tejidos reproductivos de cítricos. La categoría de 'transporte de lípidos' incluyó, principalmente, genes que codifican proteínas de transferencia de lípidos (LTPS) (Tabla Suplementaria XXIV). Las LTPs constituyen un grupo de proteínas abundantes en plantas. La capacidad de unión de las LTPs con ácidos grasos y de transferencia de fosfolípidos entre membranas ha sido demostrada in vitro pero su función biológica todavía no se conoce. Sin embargo, se ha sugerido un posible papel en el ensamblaje de la cutina y las ceras y en la defensa de las plantas frente al ataque por patógenos (Arondel et al, 2000). La caracterización de la expresión de los miembros de la familia LTP en Arabidopsis ha mostrado una expresión elevada en flores (Clark y Bohnert, 1999; Arondel et al, 2000). La identificación de los unigenes de cítricos que codifican LTPs como diferencialmente expresados en tejidos reproductivos resulta consistente con los estudios de expresión realizados previamente en Arabidopsis.

Finalmente, en el conjunto de unigenes diferencialmente expresados en los tejidos reproductivos de cítricos se identificaron diversos TFs (Tabla Suplementaria XXIII). En la Figura 37 se muestran los valores de expresión, representados como porcentaje de expresión en cada uno de los tejidos estudiados (lámina foliar, nervio central y peciolo de la hoja, entrenudo y raíz) respecto a la expresión obtenida en el conjunto de los tejidos reproductivos, para 6 unigenes de cítricos que codifican TFs.

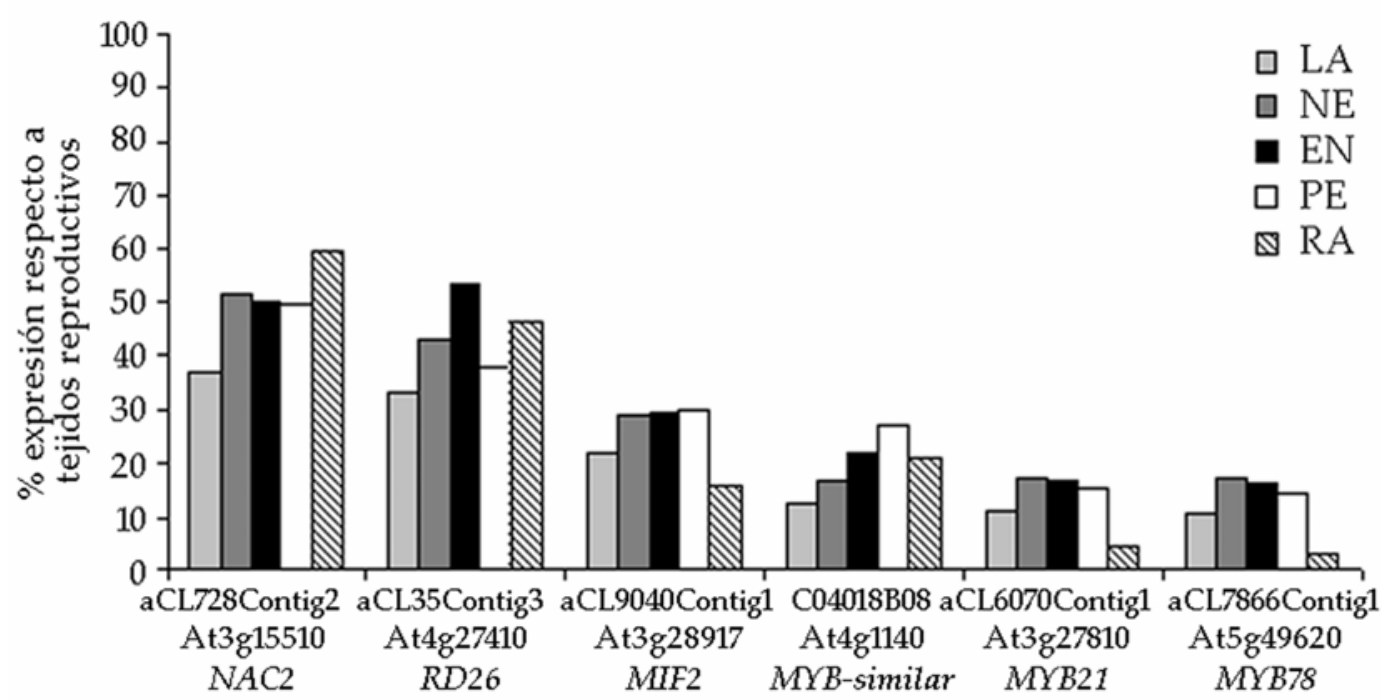

Fig. 37. Porcentaje de expresión en cada uno de los tejidos vegetativos analizados (lámina foliar, NA; nervio central de la hoja, NE; entrenudo, EN; peciolo, PE y raíz, RA) respecto a la expresión obtenida en el conjunto de los tejidos reproductivos para los siguientes genes de cítricos que codifican factores de transcripción de la familia NAC: aCL728Contig2 y aCL35Contig3; de la subfamilia MIF (aCL9040Contig1) y de la familia MYB: aC04018B08, aCL6070Contig1 y aCL7866Contig1. 
La familia MYB de TFs es una de las más extensas en plantas, con 198 miembros en Arabidopsis. En los últimos años, los genes de dicha familia MYB han sido implicados en diversos procesos fisiológicos y bioquímicos (Yanhui et al, 2006). Sin embargo, para muchos de los miembros de la familia todavía no se dispone de información funcional. La secuencia del unigen de cítricos aCL6070Contig1 fue similar a la del gen MYB21 (At3g27810) de Arabidopsis, especie en la que se ha demostrado que dicho gen codifica un TF específico de flor (Shin et al, 2002) y regula importantes aspectos de la respuesta a jasmonato durante el desarrollo de los estambres (Mandaokar et al, 2006). El unigen aCL7866Contig1 mostró una elevada similitud de secuencia con el gen MYB78 de Arabidopsis. La función de dicho gen aún no ha sido estudiada, pero los patrones de expresión obtenidos en nuestro trabajo muestran una clara expresión diferencial en tejidos reproductivos de cítricos. La secuencia del unigen aCL9040Contig1 fue similar al gen MIF2 de Arabidopsis, cuya expresión es elevada en flores y frutos (Hu y Ma, 2006). La identificación de nuevos TFs diferencialmente expresados en los tejidos reproductivos supone la base para el estudio de su posible papel en la regulación del desarrollo reproductivo en cítricos.

\subsection{Identificación de los genes preferentemente expresados en los tejidos vegetativos}

La identificación de los genes de cítricos con expresión diferencial en tejidos vegetativos se realizó mediante dos tipos de análisis SAM (Tusher et al, 2001): 1) análisis SAM de una clase para la comparación del conjunto de tejidos vegetativos con el conjunto de tejidos reproductivos y 2) análisis SAM de dos clases para la comparación del conjunto de tejidos vegetativos con la raíz, manteniendo un valor de FDR menor al $5 \%$ en ambos casos. Adicionalmente se aplicó un límite de expresión de al menos 1.6 veces de modo que el análisis fue más estricto (ver apartado 6.7 de Materiales y Métodos). En estas condiciones se identificaron un total de 185 unigenes de cítricos ( $3 \%$ de los unigenes de CIT1) expresados diferencialmente en tejidos vegetativos (Tabla Suplementaria XXV). El análisis de enriquecimiento funcional, realizado con el programa FatiGO (Al-Shahrour et al, 2004), mostró una sobrerepresentación significativa de los genes implicados en la GO no redundante de 'transporte fotosintético de electrones en el fotosistema l' (GO:0009773, $p=1 \cdot 10^{-2}$ ) (Fig. 38). Los genes relacionados con la cadena de transporte electrónico, como los que codifican las diferentes subunidades de los fotosistemas I y II, ferredoxina o plastocianina, junto a los que codifican diferentes proteínas de unión a clorofila 
mostraron, como cabía esperar, una expresión diferencial en los tejidos vegetativos (Tabla Suplementaria XXV).

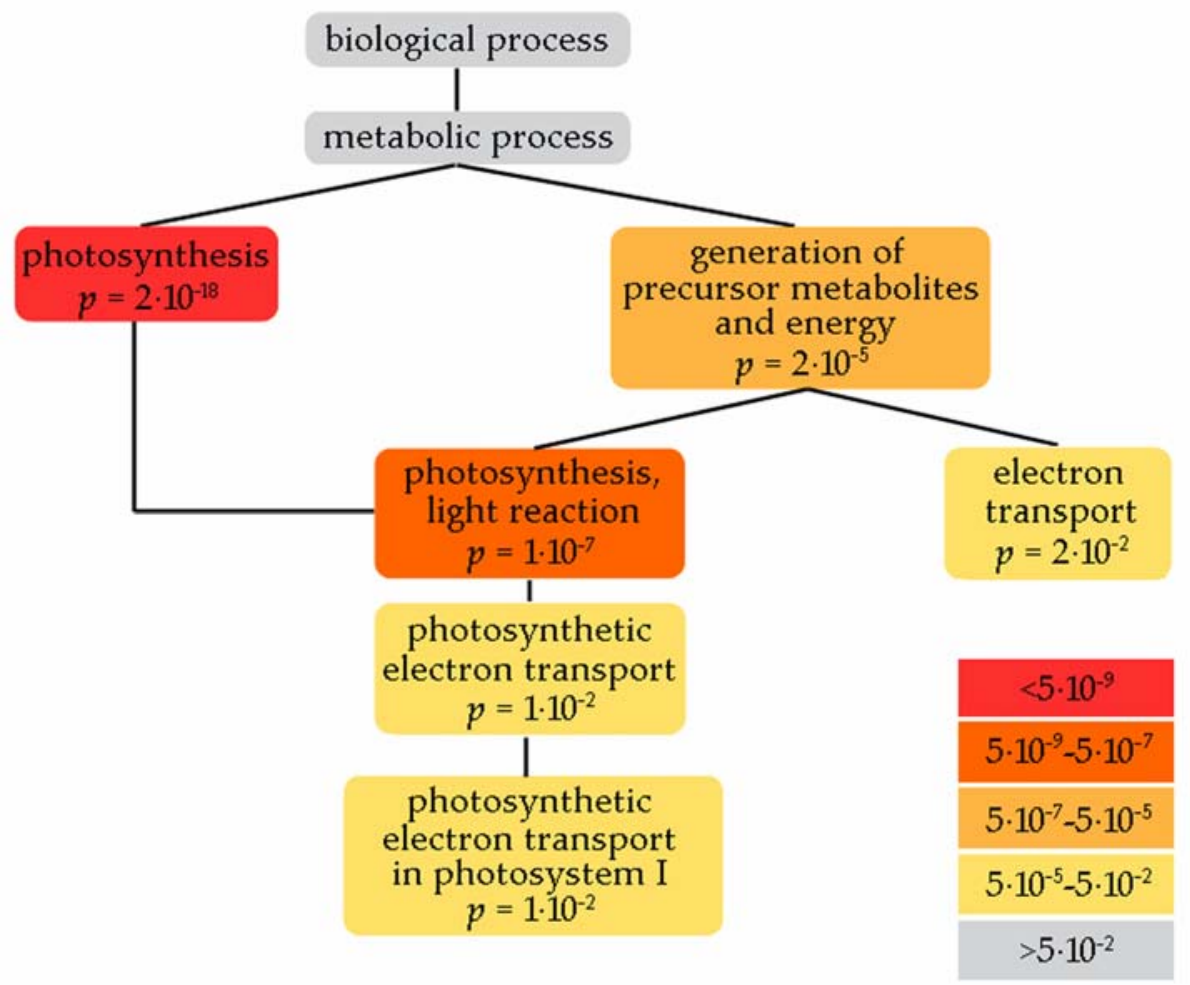

Fig. 38. Ontologías génicas de la componente 'proceso biológico' sobre-representadas en el conjunto de unigenes expresados diferencialmente en los tejidos vegetativos. La escala de color muestra el nivel de significatividad, considerando ontologías enriquecidas aquéllas cuyo valor $p$ corregido es inferior a 0.05 .

En el conjunto de unigenes expresados diferencialmente en tejidos vegetativos se identificaron 4 unigenes que codifican TFs y reguladores de la transcripción ( $2 \%$ de los TFs representados en CIT1) (Tabla Suplementaria XXIII). La secuencia del unigen aCL2656Contig1 fue similar al gen CCA1. En Arabidopsis, la mayor expresión de este gen se encuentra en hojas (Wang et al, 1997). El unigen aCL6460Contig1 mostró una secuencia similar al gen ICU4, que está implicado en la morfogénesis de las hojas en Arabidopsis (Serrano-Cartagena et al, 2000). El unigen aCL198Contig1 corresponde con el gen XERICO, un regulador del metabolismo de ABA cuya expresión es mayor en el meristemo apical del brote (Ko et al, 2006). En cuanto a los genes expresados diferencialmente en entrenudos o en hojas (ver apartado 1.2), cabe señalar que ninguno de ellos, excepto el unigen aCL11Contig1, que codifica una proteína relacionada con lectina, mostró una expresión diferencial en tejidos vegetativos. 



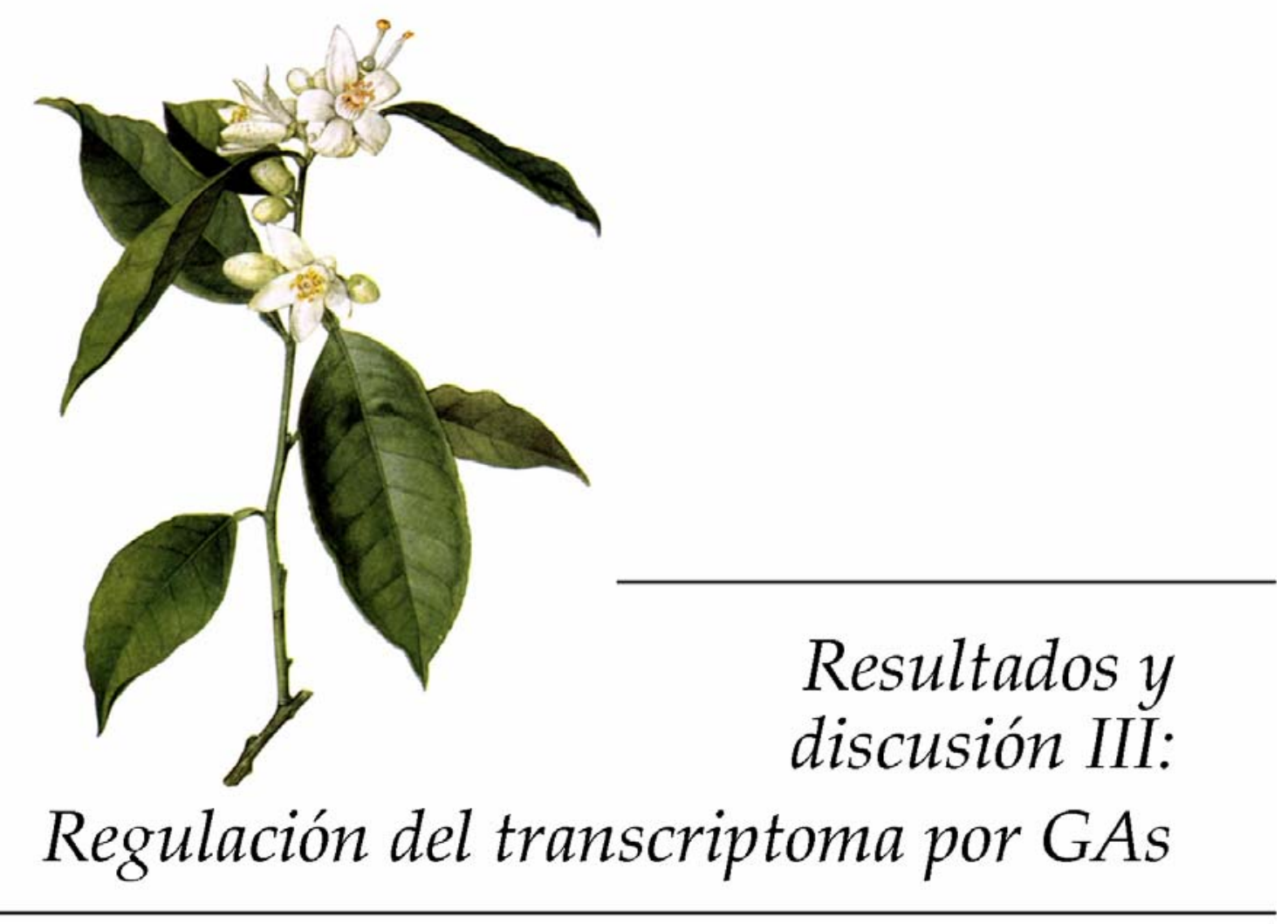





\section{CAMBIOS EN LA EXPRESIÓN GÉNICA DE ENTRENUDOS DE PLANTAS TRANSGÉNICAS DE CÍTRICOS QUE SOBRE-EXPRESAN UNA GA 20-oxidasa}

\subsection{La sobre-expresión en sentido y en antisentido del gen CCGA20ox1 modifica los niveles de transcritos endógenos de CCGA200x1}

Las plantas transgénicas de citrange Carrizo, un importante patrón de cítricos, que sobre-expresan un gen de cítricos que codifica una GA 20-oxidasa (CcGA20ox1), tanto en sentido como en antisentido, muestran una arquitectura modificada que se correlaciona con mayores (sentido) o menores (antisentido) niveles de GAs (Fagoaga et al, 2007). En este trabajo se seleccionaron dos líneas representativas; la línea S23, de sobre-expresión de CCGA20ox1 en sentido y la línea A4, que sobre-expresa dicho gen en antisentido. El contenido de $\mathrm{GA}_{1}$ en estas líneas está significativamente alterado en brotes en desarrollo, de modo que mientras los niveles de $\mathrm{GA}_{1}$ en el control son de $8.0 \mathrm{ng} / \mathrm{g}$ peso fresco, en las plantas S23 y A4 son de $22.3 \mathrm{ng} / \mathrm{g}$ peso fresco y $4.6 \mathrm{ng} / \mathrm{g}$ peso fresco, respectivamente (Fagoaga et al, 2007). En concreto, se estudiaron los entrenudos procedentes de brotes jóvenes de estas plantas porque se sabe que el crecimiento de estos órganos depende de GAs (Reid y Howell, 1995; Israelsson et al, 2004; Sun, 2004).

Previamente a la caracterización del transcriptoma de estas plantas, se confirmó que las líneas transgénicas seleccionadas en este trabajo contenían niveles elevados de transcritos correspondientes al transgén CcGA20ox1 (Fig. 39A). Los niveles de transcritos de CCGA20ox1 en la línea S23 fueron 11 veces superiores a los obtenidos en las plantas control. Asimismo, se observó un aumento de 13 veces en la línea A4 respecto a los niveles de transcritos de CCGA200x1 obtenidos en las plantas control. Por otro lado, se analizaron mediante RT-PCR los niveles endógenos de transcritos de CCGA20ox1 utilizando una secuencia de la región 3' no codificante del gen que no está incluida en el transgén (Fig. 39B). En la línea S23 no fue posible detectar los transcritos correspondientes al gen CCGA200x1 endógeno; probablemente como resultado del mecanismo de regulación por retroalimentación negativa que, previamente se ha mostrado que regula la transcripción de este gen utilizando aplicaciones de $\mathrm{GA}_{3}$ y paclobutrazol (Vidal et al, 2003). En el caso de la línea A4, la reducción observada en los niveles endógenos de transcritos de CCGA200x1 fue variable entre las réplicas biológicas, con una reducción promedio del 50\% (Fig. 39B). El mismo tipo de material que el descrito en este análisis se utilizó para evaluar los cambios de expresión génica en las líneas transgénicas seleccionadas. 
A

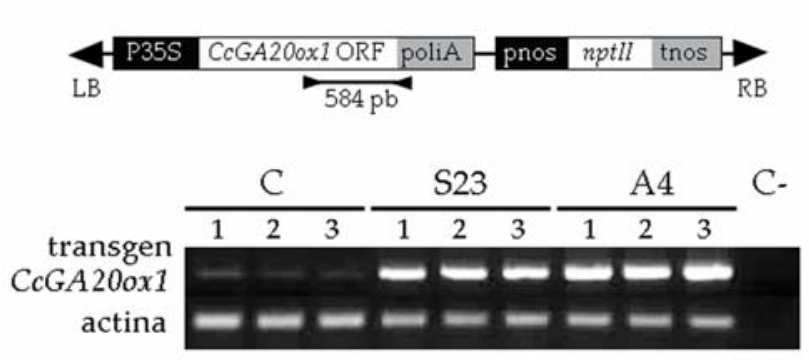

B
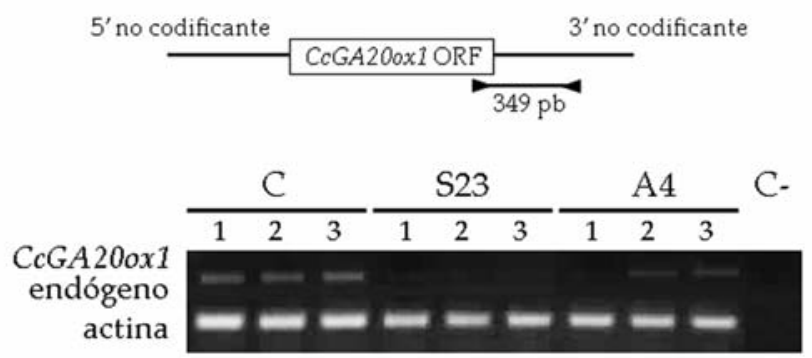

Fig. 39. Niveles de transcritos del transgén CcGA20ox1 (A) y del gen CcGA20ox1 endógeno $(B)$ en tres réplicas biológicas de las líneas representativas de sobre-expresión en sentido (S23), en antisentido (A4) y en la línea control (C). Los niveles de transcritos se determinaron mediante RT-PCR semicuantitativa tal como se describe en el apartado 7.2 de Materiales y Métodos, utilizando una actina de cítricos (CX289161) como control interno.

\subsection{La sobre-expresión en sentido del gen CCGA200x1 causa un remodelado substancial del transcriptoma}

La caracterización del transcriptoma de plantas transgénicas de cítricos que presentan niveles modificados de GA (por sobre-expresión en sentido y en antisentido del gen CCGA20ox1), y por tanto una arquitectura de la planta modificada (Fig. 40A) (Fagoaga et al, 2007), se llevó a cabo utilizando la micromatriz CIT1 (Forment et al, 2005; ver apartado 5 de Materiales y Métodos). El diseño del experimento consistió en comparaciones directas, es decir, las muestras procedentes de las plantas que sobreexpresan el gen CCGA20ox1 se compararon con los controles, plantas transformadas con el vector vacío, en la misma micromatriz (Fig. 40B). Se realizaron tres réplicas biológicas, cada una de ellas compuesta de tres entrenudos procedentes de brotes jóvenes en desarrollo de la línea representativa de sobre-expresión en sentido (S23) o en antisentido (A4). EI RNA de entrenudos de brotes jóvenes en desarrollo de plantas transformadas con el vector vacío (plantas control) se juntó y se utilizó como referencia con significado biológico. Los criterios de diseño se especifican con más detalle en el apartado 6 de Materiales y Métodos. 
A

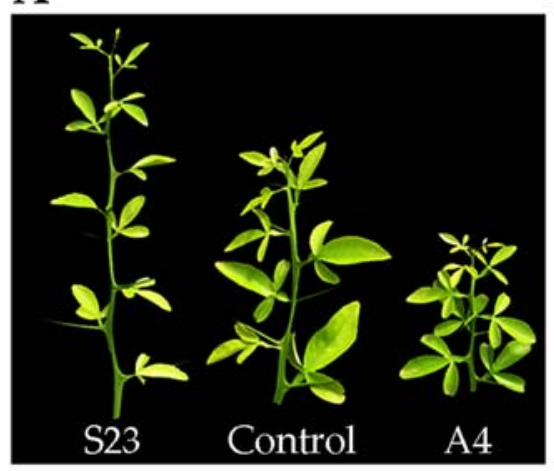

B

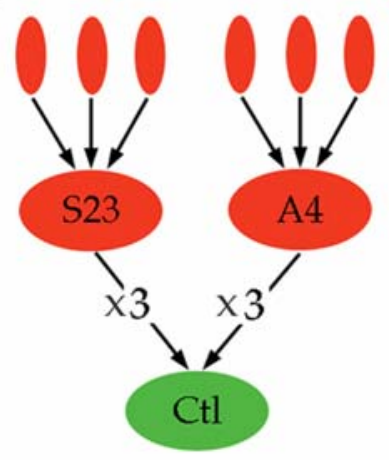

Fig. 40. Diseño del experimento. A, El transcriptoma de las plantas transgénicas que sobre-expresan el gen CcGA20ox1 se analizó a partir de los entrenudos de brotes en desarrollo de las líneas S23 y A4. B, Las muestras procedentes de las líneas transgénicas se marcaron con el compuesto fluorescente Cy5 y se compararon con las procedentes de plantas control, marcadas con Cy3, mediante la co-hibridación en la misma micromatriz. Se realizaron tres réplicas biológicas para cada comparación directa.

La Figura 41A muestra los diagramas de caja del $\log _{2}$ de los cocientes de expresión (Cy5/Cy3) tras la normalización de los datos con la función Lowess (Yang et al, 2002; ver apartado 6.5 de Materiales y Métodos) para cada una de las tres réplicas correspondientes a la línea de sobre-expresión en sentido ( $\mathrm{S} 1, \mathrm{~S} 2, \mathrm{~S} 3$ ) y en antisentido (A1, A2, A3). Los diagramas de caja mostraron una dispersión muy similar en cada grupo de datos, lo que refleja una buena reproducibilidad en cada uno de los dos grupos de réplicas. Las réplicas de la línea A4 presentaron una amplitud menor que las réplicas de la línea $\mathbf{S 2 3}$, lo que indica que los cambios en el transcriptoma correspondientes a la línea en antisentido son menores que los observados para la línea en sentido. La representación de los datos de expresión correspondientes a ambos grupos de réplicas mediante 'gráficos de volcán' confirmó esta observación (Fig. 41B). Los 'gráficos de volcán' representan, para cada uno de los genes de la micromatriz, la relación entre los cocientes de expresión y los valores de probabilidad de que las diferencias observadas ocurran por casualidad (valor $p$ ), de modo que los sectores superior izquierdo y derecho incluyen los cambios de expresión estadísticamente significativos. El gráfico correspondiente a las réplicas de la línea en sentido mostró un elevado número de datos en dichos sectores mientras que aparecieron casi vacíos en el caso de las réplicas correspondientes a la sobreexpresión en antisentido de CcGA200x1 (Fig. 41B). Por tanto, como era de esperar, se observó un elevado número de genes expresados diferencialmente en la línea S23 mientras que no se encontraron diferencias significativas entre el transcriptoma de la línea A4 y del control. La ausencia de cambios en el transcriptoma de la línea A4 puede deberse a la relativamente baja reducción del contenido de GAs en estas 
plantas (8.0 ng/g peso fresco en el control frente a $4.6 \mathrm{ng} / \mathrm{g}$ peso fresco en la línea A4, Fagoaga et al, 2007). Por lo tanto, sólo se describirán los resultados obtenidos con las plantas que sobre-expresan el gen CcGA20ox1 en sentido, en adelante, plantas CCGA200x.

A

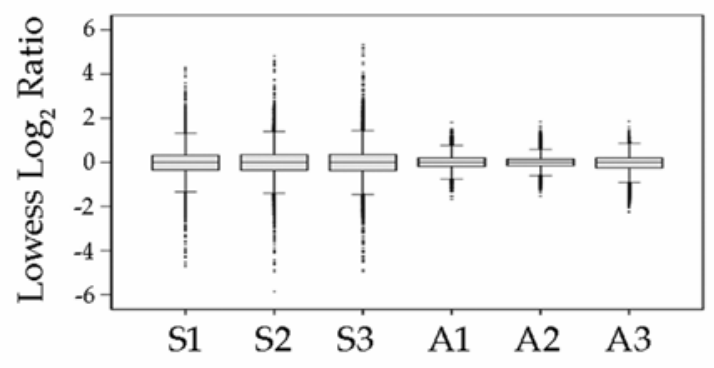

B

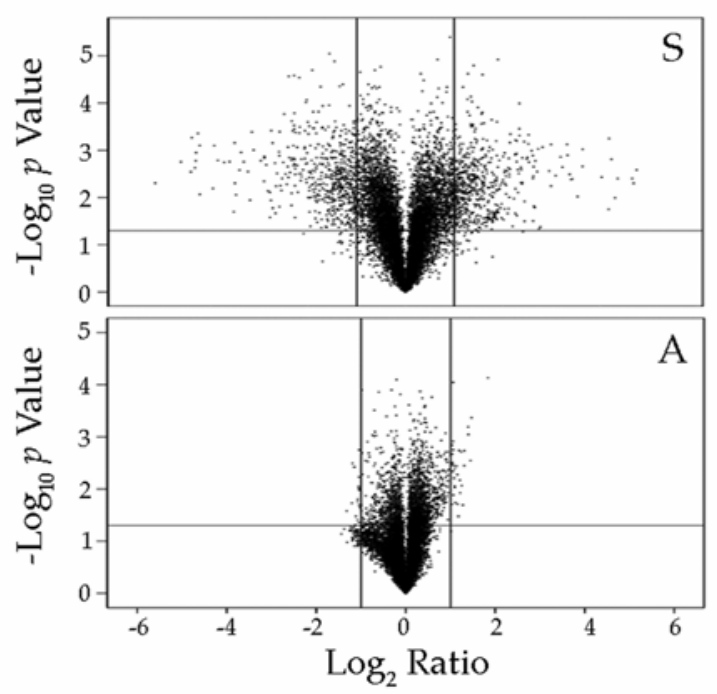

Fig. 41. Cambios globales en la expresión génica de entrenudos de citrange Carrizo que sobre-expresan el gen CCGA20ox1 en sentido y en antisentido. A, Los diagramas de caja muestran la distribución del $\log _{2}$ del cociente de intensidades tras la normalización Lowess para cada una de las tres réplicas en sentido $(S 1, S 2, S 3)$ y de las tres en antisentido (A1, A2, A3). $B$, Los gráficos de volcán representan el efecto de la sobre-expresión del gen CcGA20ox1 en sentido (S) y en antisentido (A). El eje $x$ muestra el promedio de la expresión relativa entre las plantas transgénicas y los controles en las tres réplicas, expresado en $\log _{2}$. El eje y muestra la significatividad de la $t$ de Student. La linea horizontal representan el umbral de $p=0.05$ y la barra vertical los cambios de expresión de dos veces.

En las plantas CCGA20ox, se identificaron un total de 1,228 ESTs que corresponden a 726 unigenes $(12 \%$ del total de unigenes de la micromatriz CIT1) con expresión diferencial ( $p$ valor del test $t$ de Student corregido según BenjaminiHochberg $\leq 0.05$ y un valor de cambio de expresión de al menos 1.6 veces). Adicionalmente, se detectaron otros 249 clones de cDNA de los cuales no se dispone 
de información de secuencia (es decir, no presentan más de 100 pb de secuencia de alta calidad) como diferencialmente expresados, pero no se consideraron en los análisis posteriores. Estos resultados indican que la modificación genética del metabolismo de GAs provoca una remodelación considerable del transcriptoma. En el total de los genes expresados diferencialmente, 336 (46.3\%) correspondieron a genes inducidos (Tabla Suplementaria XXVI) y 390 (53.7\% del total) a genes reprimidos (Tabla Suplementaria XXVII). El hecho de que ambas proporciones sean similares sugiere que ambos modos de regulación, inducción y represión, tienen una importancia similar en la respuesta a la sobre-expresión del gen CCGA20ox1. Resulta de interés destacar que un $14.6 \%$ de los genes expresados diferencialmente (106) no mostraron similitud de secuencia significativa con ninguna proteína de Arabidopsis. Este grupo probablemente incluye los genes específicos de cítricos y el valor relativamente elevado obtenido refleja la importancia de la secuenciación de ESTs en diferentes especies vegetales. Algunos de estos genes podrían estar implicados en funciones o rutas metabólicas específicas de cítricos.

La anotación de los unigenes expresados diferencialmente (Tablas Suplementarias XXVI y XXVII) se desarrolló mediante análisis de similitud de dichas secuencias, tal como se describe en el apartado 4.3 de Materiales y Métodos. En el análisis funcional y en la discusión de los unigenes de cítricos expresados diferencialmente, se utilizó la proteína de Arabidopsis más similar para cada unigen, de modo que fue posible realizar esta asignación en un $85.4 \%$ de los genes expresados diferencialmente (620 unigenes). Con el objetivo de obtener una visión más integrada de los cambios de expresión génica observados y para explorar los procesos biológicos en los que los genes expresados diferencialmente se encuentran implicados, se obtuvo la anotación funcional del MIPS mediante la herramienta FunCat (Ruepp et al, 2004; ver Tabla Suplementaria XXVIII para los unigenes inducidos y Tabla Suplementaria XIX para los unigenes reprimidos). En la mayoría de las categorías funcionales, la proporción de genes inducidos fue similar a la proporción de genes reprimidos (Tabla 23). Sin embargo, se observó una tendencia hacia la inducción en las categorías de 'Energía' (4.4\% frente a 1.8\%) e 'Interacción con el Ambiente' $(7.0 \%$ frente a $3.9 \%)$. Por otro lado, se observó una tendencia hacia la represión en la categoría de 'Síntesis de Proteínas' (1.4\% frente a 7.9\%). 


\begin{tabular}{|c|c|c|c|c|}
\hline \multirow{2}{*}{ CATEGORÍA FUNCIONAL } & \multicolumn{2}{|c|}{ Inducidos } & \multicolumn{2}{|c|}{ Reprimidos } \\
\hline & No. & $\%$ & No. & $\%$ \\
\hline 01 Metabolismo & 73 & 14.6 & 66 & 10.6 \\
\hline 02 Energía & 22 & 4.4 & 11 & 1.8 \\
\hline 04 Proteínas de Reserva & 1 & 0.2 & - & 0.0 \\
\hline 10 Ciclo Celular y Procesamiento del DNA & 5 & 1.0 & 11 & 1.8 \\
\hline 11 Transcripción & 10 & 2.0 & 9 & 1.4 \\
\hline 12 Síntesis de Proteínas & 7 & 1.4 & 49 & 7.9 \\
\hline 14 Procesado de proteínas (plegamiento, modificación, destino) & 23 & 4.6 & 35 & 5.6 \\
\hline 16 Proteínas con Función de Unión o Necesidad de Cofactores & 60 & 12.0 & 99 & 15.9 \\
\hline 18 Regulación del Metabolismo & 5 & 1.0 & 7 & 1.1 \\
\hline 20 Transporte Celular & 32 & 6.4 & 32 & 5.1 \\
\hline 30 Comunicación Celular - Transducción de Señal & 8 & 1.6 & 9 & 1.4 \\
\hline 32 Defensa & 32 & 6.4 & 32 & 5.1 \\
\hline 34 Interacción con el Ambiente & 35 & 7.0 & 24 & 3.9 \\
\hline 36 Interacción Sistémica con el Ambiente & 11 & 2.2 & 14 & 2.2 \\
\hline 40 Procesado Celular & 3 & 0.6 & 6 & 1.0 \\
\hline 41 Desarrollo (Sistémico) & 8 & 1.6 & 13 & 2.1 \\
\hline 42 Biogénesis de Componentes Celulares & 8 & 1.6 & 14 & 2.2 \\
\hline 43 Diferenciación de Tipos Celulares & 2 & 0.4 & 3 & 0.5 \\
\hline 47 Diferenciación de Órganos & - & - & 3 & 0.5 \\
\hline 70 Localización Subcelular & 111 & 22.2 & 142 & 22.8 \\
\hline 77 Localización en Órganos & 3 & 0.6 & - & - \\
\hline 99 Proteínas sin Clasificación & 40 & 8.0 & 44 & 7.1 \\
\hline TOTAL & 499 & 100.0 & 623 & 100.0 \\
\hline
\end{tabular}

Los resultados obtenidos en los análisis de expresión génica con la micromatriz CIT1 se confirmaron mediante el análisis de la expresión, por RT-PCR con oligonucleótidos específicos, de 6 unigenes expresados diferencialmente en las plantas CCGA200x1 y en los controles. Se seleccionaron unigenes relacionados con la fotosíntesis (aCL48Contig1, RuBisCo activasa; y aCL43Contig3, subunidad pequeña de RuBisCo), con estrés de origen abiótico (aCL172Contig2, RD22), con la pared celular (aCL3307Contig1, xiloglucano endotransglucosilasa/hidrolasa), con el metabolismo secundario (aCL960Contig1, geranilgeranil difosfato sintasa) y un unigen (aCL8Contig9) cuya secuencia no muestra similitud significativa con ninguna secuencia de las bases de datos consultadas (ver apartado 4.3 de Materiales y Métodos). Los niveles de transcritos de los 6 genes examinados (Fig. 42A) mostraron un alto grado de concordancia con los cambios de expresión génica detectados en el análisis transcriptómico, que se expresa mediante la buena correlación $(R=0.96)$ obtenida entre ambos métodos (Fig. 42B). Así pues, los resultados obtenidos mediante RT-PCR apoyan los generados con la aproximación transcriptómica utilizando la micromatriz CIT1, demostrando la reproducibilidad de los datos obtenidos en nuestras condiciones experimentales. 
A

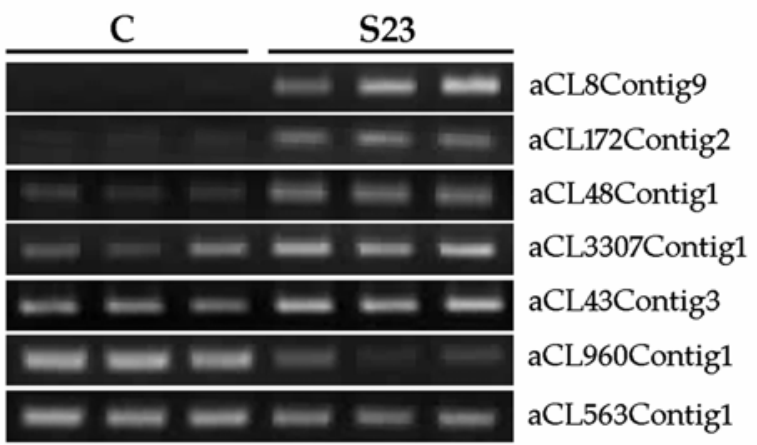

B

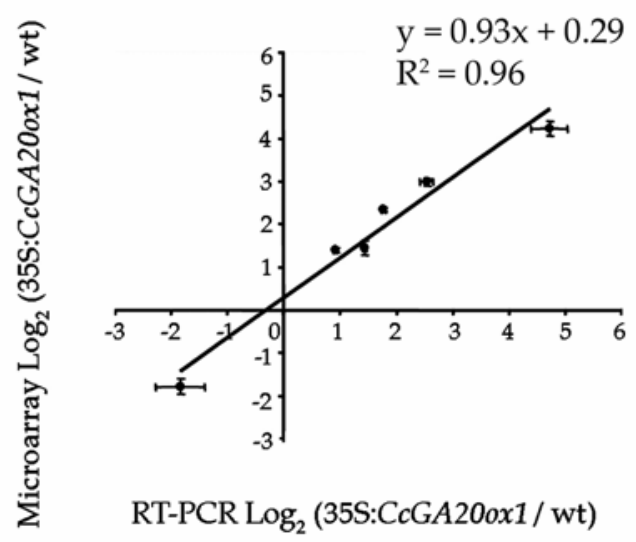

Fig. 42. Confirmación de los datos obtenidos con la micromatriz CIT1 mediante RT-PCR. A, La expresión de seis unigenes expresados diferencialmente en las plantas CCGA20ox se ha estudiado por RT-PCR semicuantitativa utilizando oligonucleótidos específicos. El gen utilizado como control interno fue una actina de cítricos (CX289161). aCL8Contig9, sin anotación; aCL172Contig2, RD22; aCL48Contig1, RuBisCo activasa; aCL3307Contig1, xiloglucano:xiloglucosil transferasa; aCL43Contig3, RuBisCo subunidad pequeña; aCL960Contig1, geranilgeranil difosfato sintasa; aCL563contig1, actina. $\mathrm{B}$, Correlación entre los resultados obtenidos mediante RT-PCR y análisis transcriptómico para seis genes expresados diferencialmente en las plantas CCGA20ox. Los valores representados corresponden a la media de tres réplicas biológicas $\pm \mathrm{SE}$.

\subsection{La sobre-expresión del gen CcGA20ox1 implica la sobre-representación de diversas ontologías génicas}

Con el objetivo de identificar procesos clave alterados en las plantas CCGA20ox realizamos un análisis de enriquecimiento funcional en el conjunto de genes expresados diferencialmente utilizando la herramienta FatiGO (Al-Shahrour et al, 2004), que está basada en Ontologías Génicas (GO) (Ashburner et al, 2000), tal como se describe en el apartado 4.3 Materiales y Métodos. 
A

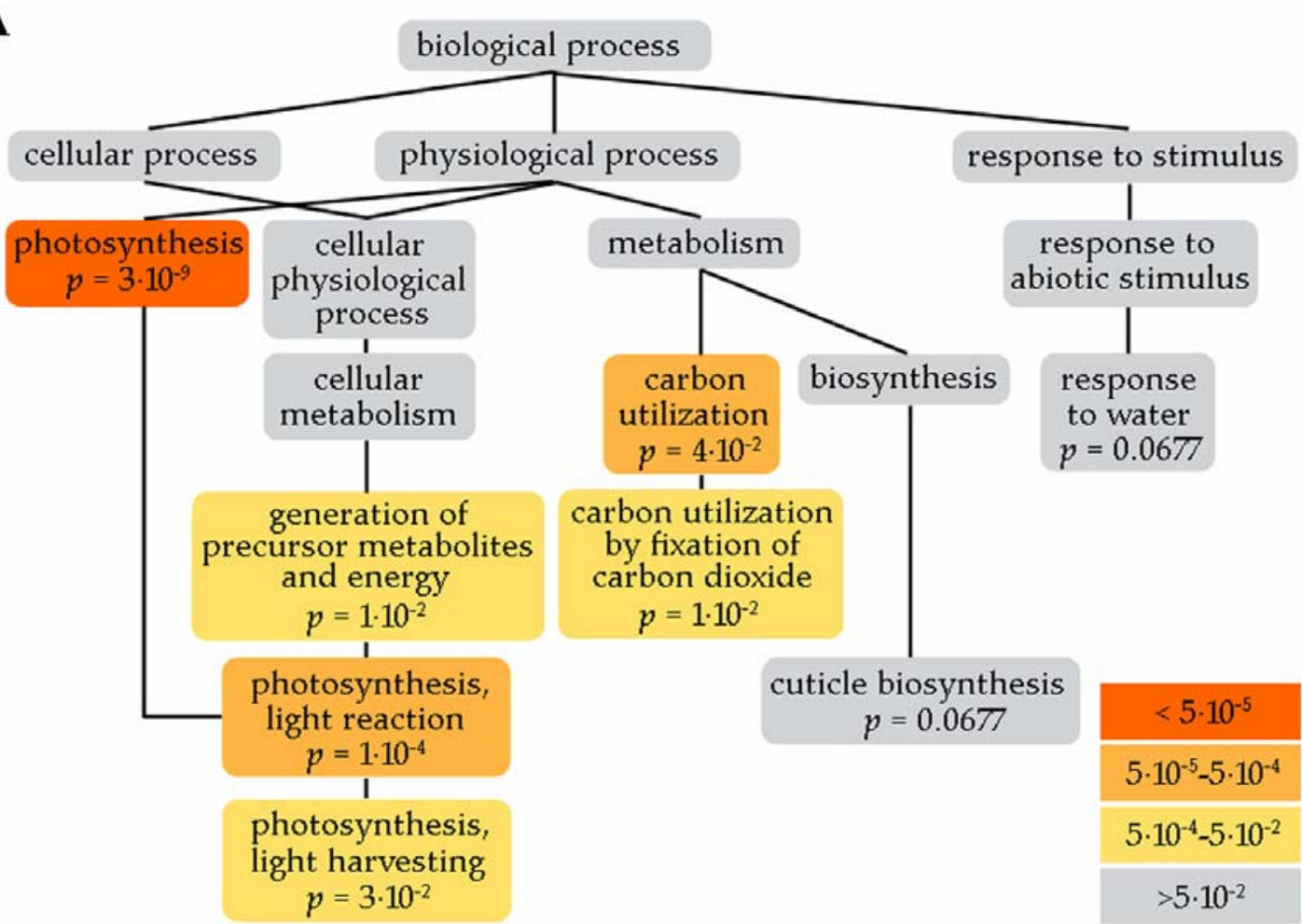

B

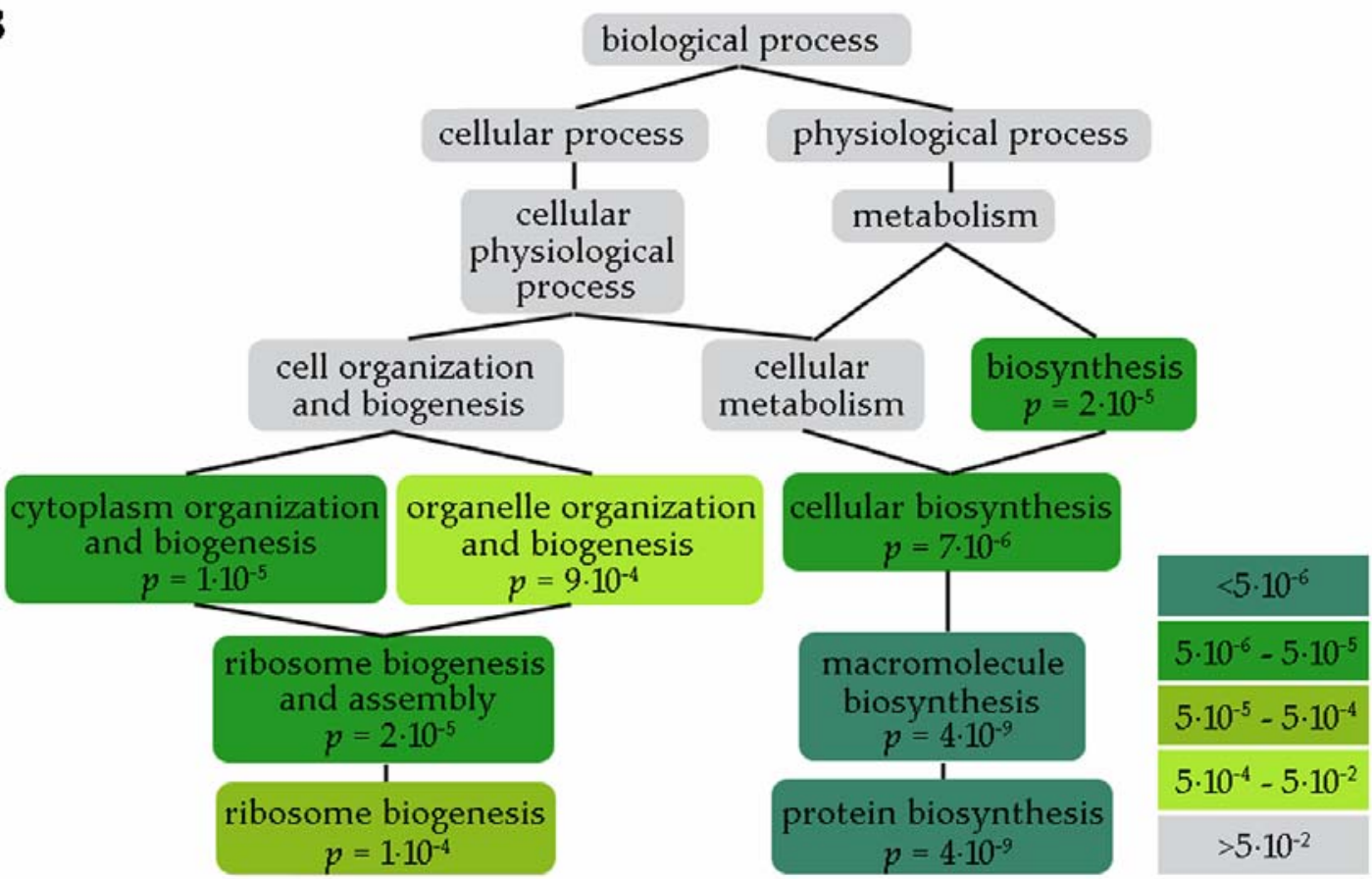

Fig. 43. Representación jerárquica de las ontologías génicas de la componente 'proceso biológico' significativamente sobre-representados en el conjunto de genes inducidos (A) y reprimidos (B) realizada a partir de los resultados obtenidos utilizando la herramienta FatiGO. Las categorías significativas (valor $p$ de un test de Fisher corregido por test múltiples $\leq 0.05$ ) se muestran utilizando una escala de colores de acuerdo a su nivel de significatividad. Las categorías necesarias para completar la jerarquía se muestran en gris. 
Las categorías GO identificadas como significativamente sobre-representadas en el conjunto de genes inducidos (Fig. 43A, Tabla Suplementaria XXX) fueron 'fotosíntesis, captación de luz' (GO:0009765, $p=0.03$ ) y 'utilización de carbono por fijación de dióxido de carbono' (GO:0015977, $p=0.01$ ), mientras que en el conjunto de genes reprimidos encontramos sobre-representadas las categorías de 'biosíntesis de proteínas' (GO:0006412, $p=4 \cdot 10^{-9}$ ) y 'biogénesis de ribosomas' (GO:0007046, $p=1 \cdot 10^{-4}$ ) (Fig. 43B, Tabla Suplementaria XXXI). Las categorías GO correspondientes a 'respuesta a agua' (GO:0009414, $p=0.0677$ ) y 'biosíntesis de la cutícula' (GO:0042335, $p=0.0677$ ) (Tabla Suplementaria XXX), se encontraron cerca del límite de significatividad establecido $(p \leq 0.05)$ por lo que se incluyeron en la Fig. $43 \mathrm{~A}$ y se discutirán más adelante.

\subsubsection{Fotosíntesis y Utilización de Carbono}

En las plantas CCGA200x se encontraron inducidos diversos genes incluidos en las categorías de 'captación de luz' (ej. proteínas de unión a clorofila a/b) y en las reacciones de transferencia de electrones (ej. ferredoxina y fotosistemas I y II), así como en las categorías de 'generación de metabolitos precursores y energía' (ej. glicolato oxidasa, fructosa-bifosfato aldolasa, tioredoxinas y ferredoxinas) y en la utilización de carbono (ej. anhidrasas carbónicas, RuBisCo y gliceraldehido 3-fosfato deshidrogenasas) (Fig. 43A, Tabla Suplementaria XXX). Dado que la categoría de 'utilización de carbono por fijación de dióxido de carbono' apareció significativamente sobre-representada, quisimos saber si otros genes del ciclo de Calvin-Benson, además de los presentes en la categoría enriquecida, estaban también inducidos. Tal como se muestra en la Figura 44, la mayoría de los genes implicados en el ciclo de Calvin-Benson estaban inducidos en las plantas CCGA20ox, incluyendo RuBisCo (2.7 veces, $p<0.05)$, GADPH (2.6 veces, $p<0.05)$, fructosa-bifosfato aldolasa (3.9 veces, $p<0.05)$ y fructosa-bifosfatasa $(1.9$ veces, $p<0.05)$. Los genes que codifican fosforibuloquinasa (3.7 veces, $p=0.059)$ y transquetolasa (1.5 veces, $p<0.05)$ se consideraron inducidos, aunque no cumplían los valores establecidos para identificarlos como diferencialmente expresados. Adicionalmente, dos unigenes de cítricos que codifican RubisCo activasa, enzima que regula la actividad de la RuBisCo, se encontraron asimismo inducidos (4.8 veces, $p<0.05)$ en las plantas CCGA20ox. Los posibles cambios en la expresión de otros genes implicados en dicha ruta, que codifican fosfoglicerato kinasa, sedoheptulosa-bifosfatasa y ribulosa-5-fosfato isomerasa, no pudieron ser evaluados porque estos genes no se encuentran 
representados en la micromatriz CIT1. Estos resultados sugieren que la sobreexpresión de CCGA20ox1 provoca un aumento en la capacidad de fijación de carbono de las plantas transgénicas.

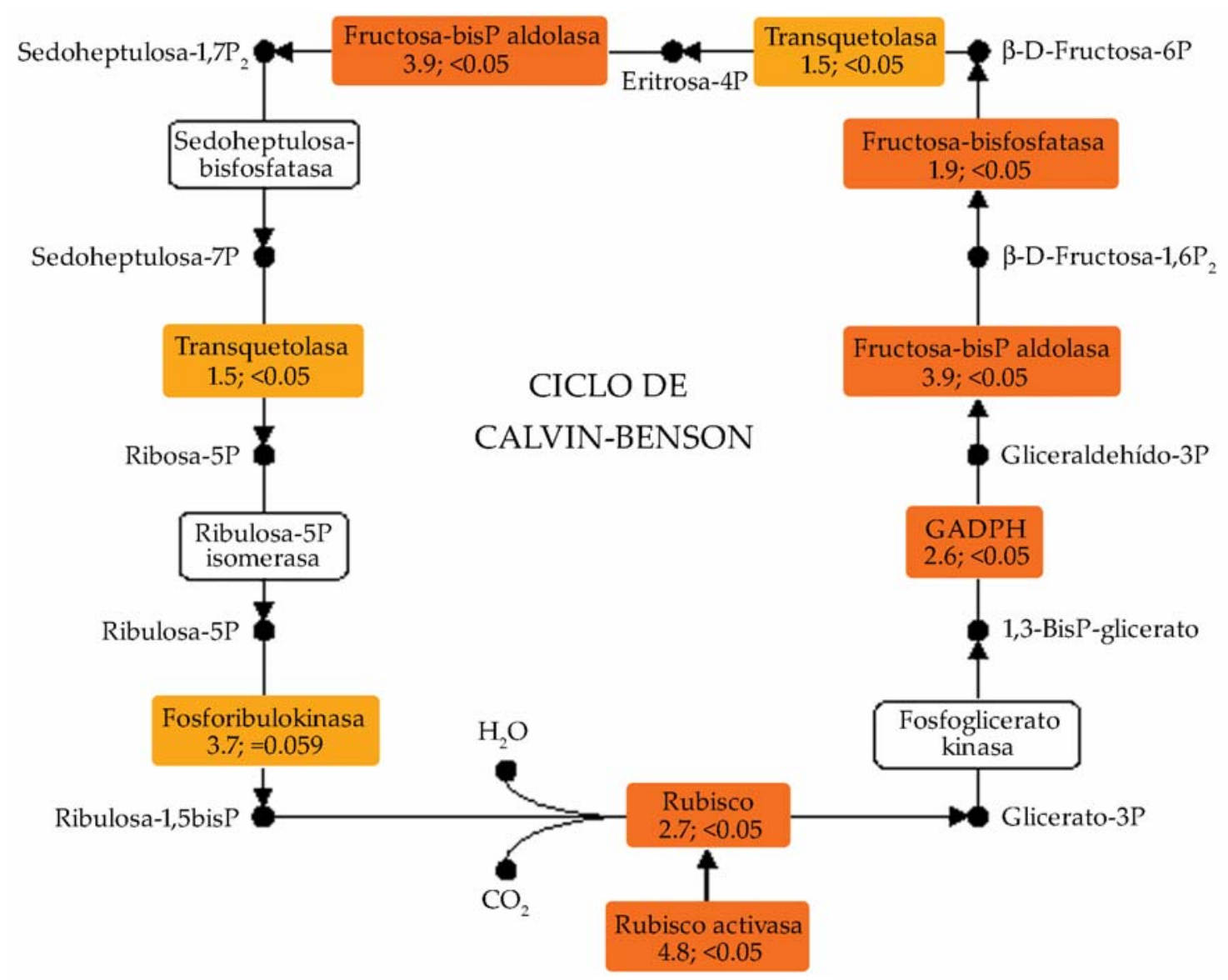

Fig. 44. Cambios en los niveles de transcritos de los genes implicados en el ciclo de Calvin-Benson en entrenudos de citrange Carrizo entre las plantas CCGA20ox y las plantas control. Los genes diferencialmente expresados (al menos un cambio de expresión de 1.6 veces y un valor $p \leq 0.05$ ) se muestran en cajas de color rojo oscuro. Las cajas de color rojo más claro corresponden a genes inducidos aunque no cumplen uno de los dos criterios.

Hasta el momento, no existen evidencias previas que muestren una activación transcripcional de los genes relacionados con la fotosíntesis y la fijación de carbono en plantas transgénicas con el metabolismo de GAs modificado. Sin embargo, diversos trabajos han señalado que el contenido de algunas proteínas implicadas en el ciclo de Calvin-Benson y en la utilización de carbono aumenta tras la aplicación de $\mathrm{GA}_{3}$. Los niveles de RuBisCo en hojas de haba y soja son mayores tras $1 \mathrm{~h}$ de tratamiento con $\mathrm{GA}_{3}$ como resultado de un aumento en la traducción (Yuan y $\mathrm{Xu}, 2001$ ). Los niveles de frutosa-bifosfato aldolasa aumentan en raíces de arroz $24 \mathrm{~h}$ después de la aplicación de $\mathrm{GA}_{3}$ (Konishi et al, 2004). Asimismo, la anhidrasa carbónica (que cataliza la hidratación reversible de $\mathrm{CO}_{2} \mathrm{y}$, por tanto, la disponibilidad de $\mathrm{CO}_{2}$ para RuBisCo) 
aumenta en hojas de Brassica juncea tras el tratamiento con $\mathrm{GA}_{3}$ (Hayat et al, 2001). Además, se ha encontrado que RuBisCo activasa tiene propiedades de unión a GAs (Komatsu et al, 1996) y que su sobre-expresión en arroz promueve un mayor crecimiento de la planta (Sharma and Komatsu, 2002).

\subsubsection{Biosíntesis de Proteínas}

Las categorías de 'biosíntesis de proteínas' y 'biogénesis de ribosomas' incluyeron, principalmente, genes que codifican proteínas ribosomales (al menos 25 pertenecientes a la subunidad ribosomal $60 S$ y 15 a la subunidad 40S) (Fig. 43B, Tabla Suplementaria XXXI). Adicionalmente, en la categoría de 'biosíntesis de proteínas' se encontraron tres factores de elongación (Tabla Suplementaria XXXI). La amplia represión de genes que corresponden a estas categorías funcionales sugiere que la maquinaria de síntesis de proteínas puede estar afectada en las plantas CCGA20ox. Sin embargo, la menor expresión de los genes incluidos en la 'biosíntesis de proteínas' y en la 'biogénesis de ribosomas' no parece afectar a la síntesis de todas las proteínas porque al menos las implicadas en la fotosíntesis y en la fijación de carbono probablemente están aumentadas. La reducción en la expresión de los genes englobados en estas categorías puede interpretarse como un cambio en el patrón de síntesis de proteínas. De acuerdo con esta hipótesis, se ha mostrado que, en células de aleurona de cebada tratadas con $\mathrm{GA}_{3}$, la síntesis proteica global es modificada para producir importantes cantidades de a-amilasa y otras proteínas inducidas por $\mathrm{GA}_{3}$, mientras que la síntesis de otras proteínas queda reducida o detenida (Mozer, 1980; Jacobsen and Beach, 1985).

La categoría de 'biosíntesis celular' también se encontró sobre-representada en el conjunto de genes reprimidos en las plantas CCGA20ox (Fig. 43B), e incluyó genes que codifican limoneno sintasa (que cataliza la ciclación de geranil difosfato en la biosíntesis de monoterpenos), sesquiterpeno sintasa (relacionada con la biosíntesis de sesquiterpenos), y flavonol 3-O-metiltransferasa, chalcona sintasa, y una oxidoreductasa 2-oxoglutarato-Fe(II) oxigenasa (estos tres últimos genes están implicados en la biosíntesis de flavonoides) (Tabla Suplementaria XXXI). La represión de todos estos genes es interesante debido a la relevancia de las rutas de biosíntesis de isoprenoides y flavonoides en cítricos (Rodrigo y Zacarías, 2006). 


\subsection{La activación transcripcional de los genes relacionados con la fotosíntesis conduce a un aumento en la capacidad fotosintética de las plantas CCGA20ox}

La inducción global observada en los genes que codifican proteínas de los fotosistemas y de unión a clorofila (Fig. 43A, Tabla Suplementaria XXX), así como en los genes implicados en la fijación de carbono (Fig. 44), nos condujo a la hipótesis de que estos cambios en la expresión génica podrían estar asociados a un aumento en la capacidad fotosintética de las plantas CcGA20ox. Para confirmar esta hipótesis, se midió la absorción neta de $\mathrm{CO}_{2}$ en hojas jóvenes de plantas CCGA20ox y en plantas control. Como muestra la Tabla 24, la absorción fotosintética de $\mathrm{CO}_{2}$ en hojas jóvenes de plantas CCGA20ox fue significativamente mayor que en las plantas control a una radiación fotosintética activa (PAR) de 800 y $1,000 \mu \mathrm{mol} \cdot \mathrm{m}^{-2} \cdot \mathrm{s}^{-1}$ mientras que no se encontraron diferencias significativas a $600 \mu \mathrm{mol} \cdot \mathrm{m}^{-2} \cdot \mathrm{s}^{-1}$ (Tabla 24). Estos resultados apoyan la conclusión de que, aunque no tenemos datos sobre la producción de biomasa de estas plantas, la inducción global de los genes que corresponden a las categorías GO sobre-representadas de 'fotosíntesis' y 'utilización de carbono' en las plantas CCGA20ox ciertamente tiene un efecto fisiológico.

El efecto observado de la sobre-expresión de CcGA20ox1 sobre la fotosíntesis puede estar relacionado con que el mesófilo (parénquima en empalizada y esponjoso) de las hojas de estas plantas es más compacto (Fagoaga et al, 2007). Resulta interesante señalar que, en tabaco, se ha observado un efecto positivo de las GAs sobre la fotosíntesis neta cuando ésta se midió en plantas enteras que sobre-expresan una GA20ox, pero no cuando se midió en hojas individuales (Biemelt et al, 2004). En este caso, sin embargo, el mesófilo de las plantas transgénicas no presentaba diferencias respecto al control. El efecto de las GAs sobre la fotosíntesis ha sido ciertamente controvertido, de modo que algunos autores han encontrado que la aplicación de $\mathrm{GA}_{3}$ tiene un efecto positivo (Yuan y Xu, 2001; Hayat et al, 2001), negativo (Dijkstra et al, 1990) o ningún efecto (Cramer et al, 1995). Estos resultados aparentemente contradictorios pueden ser debidos a los diferentes sistemas experimentales y métodos utilizados por los autores para determinar la fotosíntesis (Nagel y Lambers, 2002). La sobre-expresión de CcGA20ox1 también incrementa significativamente tanto la conductancia estomática $\left(\mathrm{g}_{\mathrm{s}}\right)$ como la tasa de transpiración (E), con independencia del valor de PAR (Tabla 24). Sin embargo, la eficiencia en el uso del agua, estimada como el cociente entre $\mathrm{Pn} / \mathrm{E}$, fue similar en las plantas CCGA20ox1 y en los controles. Únicamente a un valor de PAR de 1000 este parámetro fue algo inferior en las plantas CCGA20ox1. 


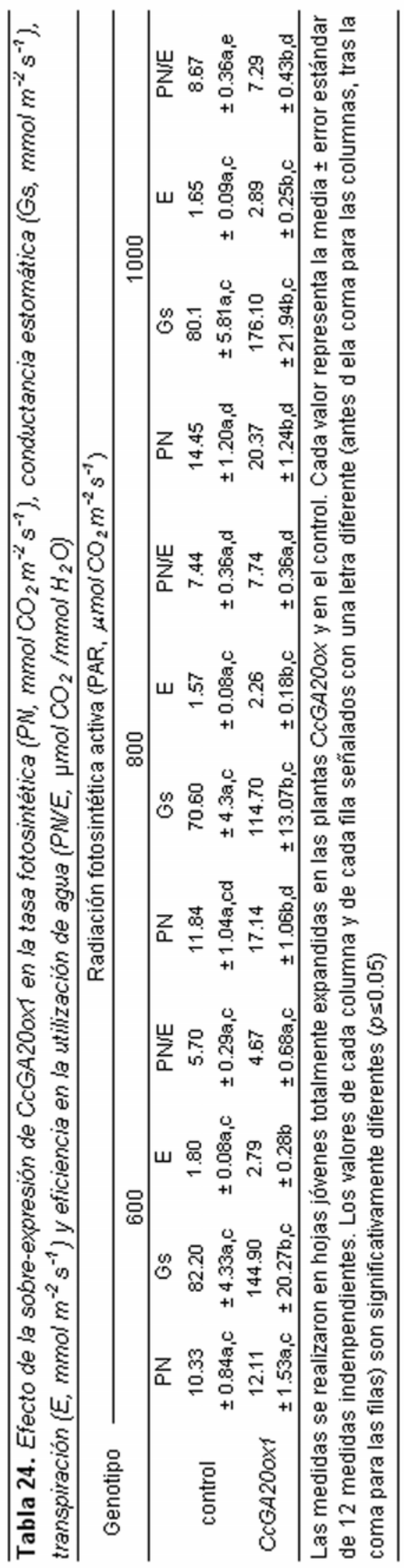




\subsection{La sobre-expresión en sentido del gen CcGA200x1 provoca cambios en los niveles de expresión de genes específicos}

Con el propósito de identificar otros procesos metabólicos y fisiológicos relacionados con el fenotipo de las plantas CCGA20ox, resultó de interés examinar los genes expresados diferencialmente en dichas plantas (Tablas Suplementarias XXVI y $\mathrm{XXVII})$ que no formaban parte de las categorías enriquecidas descritas anteriormente.

\subsubsection{Metabolismo de GAs}

Respecto a los genes implicados en el metabolismo de GAs, la micromatriz CIT1 contiene dos unigenes, aC08003D01 y aC18016F11, cuya secuencia es similar a GA 2-oxidasa2 de Arabidopsis (GA2ox2, At1g30040). Sin embargo, ninguno de ellos mostró una expresión diferencial ni en las plantas transgénicas ni en los explantes tratados con $\mathrm{GA}_{3}$ comparados con el control. El hecho de que estos unigenes de cítricos no parezcan inducirse por GAs indica que no están sujetos a la regulación por retroalimentación positiva, contrariamente a lo que sucede con el gen GA2ox2 de Arabidopsis (Thomas et al, 1999). El único gen del metabolismo de GAs de cítricos del que se conoce su regulación por retroalimentación negativa es CcGA20ox1 (Vidal et al, 2003), pero este gen no se encuentra en la micromatriz de cDNA de cítricos utilizada en este análisis transcriptómico. Sin embargo, los datos obtenidos mediante RT-PCR (Fig. 39B) confirmaron que en las plantas CcGA20ox la expresión del gen enndógeno CCGA200x1 es muy reducida; probablemente como resultado del mecanismo de regulación por retroalimentación negativa.

\subsubsection{Biosíntesis y modificación de la pared celular}

La pared celular vegetal es una entidad compleja, diversa y dinámica, puesto que cambia durante los procesos de división, crecimiento y diferenciación celular. La dinámica de la pared celular depende de numerosas enzimas y proteínas estructurales, la mayoría de ellas codificadas por familias multigénicas que, con frecuencia, exhiben perfiles de expresión y funciones fisiológicas diferentes (Imoto et al, 2005). Las GAs inducen la elongación y/o división celular y se ha sugerido que las plantas CCGA20ox presentan un aumento en las divisiones celulares en los entrenudos en elongación (Fagoaga et al, 2007). Por lo tanto, cabía esperar que los niveles de transcritos correspondientes a las enzimas implicadas en la división celular estuvieran modificados en esas plantas. Sin embargo, en el conjunto de genes 
expresados diferencialmente en las plantas CCGA20ox no se observaron genes relacionados con la división celular sino con la biosíntesis y modificación de la pared celular. Así pues, en las plantas CcGA20ox se observó la inducción de los unigenes que codifican una endo-1,4- $\beta$-D-glucanasa, requerida para la formación normal de celulosa, una proteína similar a celulosa sintasa, implicada en la síntesis de polisacáridos de la matriz (Cosgrove, 2005), y cuatro $\beta$-1,3-glucanasas, que rompen la callosa, polisacárido abundante en la placa celular de las células en división y que también se deposita tras la exposición a estrés de tipo abiótico o biótico (Scheible y Pauly, 2004) (Tabla 25). Además, se observó la inducción de tres unigenes que codifican xiloglucano endotransglucosilasa-hidrolasa $(\mathrm{XTH})$, enzima que regula la extensión de la pared celular (Tabla 25). Previamente, se ha descrito un efecto positivo del tratamiento con $\mathrm{GA}_{3}$ tanto en la actividad de XTH (Potter y Fry, 1993; Smith et al, 1996) como en la expresión de XTH (Uozu et al, 2000; Jan et al, 2004). Los resultados obtenidos indican que la elongación de los entrenudos de las plantas CcGA200x es consecuencia de procesos de elongación celular, resultado tanto de la relajación de la pared celular (indución de genes $X T H$ ) como de la síntesis de celulosa (inducción de endo-1,4- $\beta$-D-glucanasa y proteína similar a celulosa sintasa).

\begin{tabular}{|c|c|c|c|}
\hline Enzimas & $\begin{array}{l}\text { Unigen de } \\
\text { cítricos }\end{array}$ & $\begin{array}{l}\text { Cambio de } \\
\text { expresión }\end{array}$ & $\begin{array}{l}\text { Gen de ATH } \\
\text { más similar }\end{array}$ \\
\hline \multicolumn{4}{|l|}{ Celulosa } \\
\hline Celulosa sintasa-like (GT2) & aCL1355Contig1 & 2.58 & At2g32540 \\
\hline Endo-1,4- $\beta$-glucanasa, KORRIGAN (GH9) & aCL5359Contig1 & 1.72 & At5g49720 \\
\hline \multicolumn{4}{|l|}{ Hemicelulosa } \\
\hline Xiloglucano endotransglucosilasa- & aCL156Contig1 & 4.44 & At1g14720 \\
\hline \multirow{3}{*}{ hidrolasa $(\mathrm{GH} 16)$} & aCL3307Contig1 & 3.68 & At5g65730 \\
\hline & aCL6772Contig1 & 2.75 & At4g37800 \\
\hline & aCL6641Contig1 & -2.51 & At5g13870 \\
\hline \multicolumn{4}{|l|}{ Callosa } \\
\hline \multirow[t]{5}{*}{$\beta-1,3-$ glucanasa $(\mathrm{GH} 17)$} & $\mathrm{aC} 04017 \mathrm{~A} 07$ & 5.17 & At4g16260 \\
\hline & aCL20Contig2 & 3.56 & At3g57270 \\
\hline & aCL20Contig7 & 2.62 & At3g57270 \\
\hline & aCL168Contig3 & 1.62 & At2g27500 \\
\hline & aCL2349Contig1 & -2.46 & At2g16230 \\
\hline \multicolumn{4}{|l|}{ Pectina } \\
\hline \multirow[t]{6}{*}{ Pectin metil esterasa (CE8) } & aCL3567Contig1 & 3.48 & At2g26440 \\
\hline & aCL1215Contig1 & 2.16 & At5g20860 \\
\hline & aCL120Contig3 & -3.20 & At3g14310 \\
\hline & aCL120Contig2 & -2.68 & At3g14310 \\
\hline & aCL120Contig1 & -2.57 & At3g14310 \\
\hline & aCL1691Contig1 & -2.68 & At1g11580 \\
\hline \multirow[t]{2}{*}{ Pectato liasa (PL1) } & aCL3827Contig2 & -2.79 & At1g04680 \\
\hline & aCL4999Contig1 & -2.01 & At1g04680 \\
\hline
\end{tabular}


Finalmente, diversos genes que codifican enzimas que modifican pectinas como pectin metil esterasa (PME) y pectato liasa $(\mathrm{PL})$ se expresaron diferencialmente (Tabla 25), lo que sugiere que el metabolismo de pectinas pudiera estar alterado en las plantas CCGA20ox. En el xilema en desarrollo de plantas transgénicas de álamo que sobre-expresan una GA 20-oxidasa de Arabidopsis (AtGA20ox1), se ha descrito la inducción de los genes que codifican PME y PL (Israelsson et al, 2003), lo que indica que el aumento observado en el crecimiento secundario de esas plantas requiere, probablemente, una mayor actividad de las enzimas que modifican pectinas. De acuerdo con esta idea, la represión de los genes $P M E$ y $P L$ de cítricos podría explicar la reducción del desarrollo del xilema observada en las plantas CcGA20ox (Fagoaga et al, 2007).

\subsubsection{Biosíntesis de lignina}

La sobre-expresión del gen AtGA20ox1 de Arabidopsis en tabaco produce un aumento en la expresión de diversos genes implicados en la biosíntesis de lignina, acompañado de un mayor contenido de lignina (Biemelt et al, 2004). Por otro lado, las plantas transgénicas de álamo que sobre-expresan el gen AtGA200x1 presentan más fibras de xilema y de mayor longitud, lo que sugiere que los niveles elevados de GA estimulan el crecimiento secundario (Eriksson et al, 2000), probablemente asociado a la mayor deposición de lignina en la pared celular. En el caso de cítricos, no se ha observado un aumento en el desarrollo del xilema, al menos en brotes jóvenes en desarrollo (Fagoaga et al, 2007). Además, entre los genes expresados diferencialmente en las plantas CCGA20ox encontramos 7 unigenes implicados en la biosíntesis de lignina, 3 inducidos y 4 reprimidos (Tabla 26), lo que no nos permite concluir si estos cambios de expresión conllevan una alteración en el contenido de lignina en cítricos.

Tabla 26. Genes expresados diferencialmente en la plantas CcGA20ox implicados en la biosíntesis de lignina

\begin{tabular}{llll}
\hline \multicolumn{1}{c}{ Enzimas } & \multicolumn{1}{c}{$\begin{array}{c}\text { Unigen de } \\
\text { Cítricos }\end{array}$} & $\begin{array}{c}\text { Cambio de } \\
\text { expresión }\end{array}$ & $\begin{array}{c}\text { Gen de ATH } \\
\text { más similar }\end{array}$ \\
\hline Fenilalanina amonio liasa (PAL) & aC02002A11 & 2.28 & At3g10340 \\
Cinamato 4-hidroxilasa (C4H) & aCL959Contig1 & 2.04 & At2g30490 \\
4-cumarato-CoA ligasa (4CL) & aCL5408Contig1 & -1.66 & At1g62940 \\
Hidroxicinamoil-CoA siquimato/quinato & aCL4633Contig1 & -3.07 & At5g48930 \\
Hidroxicinamoil transferasa (HCT) & aCL6878Contig1 & -2.13 & At5g48930 \\
& aCL602Contig1 & -1.89 & At5g48930 \\
Cafeoil-CoA O-metiltransferasa (CCoAMT) & aCL139Contig2 & 1.92 & At4g34050 \\
\hline
\end{tabular}




\subsubsection{Estrés de origen abiótico}

Diversos trabajos sugieren que las GAs podrían estar implicadas en el estrés originado por diferentes tipos de factores abióticos (Achard et al, 2006; Magome et al, 2004). Puesto que las categorías GO de 'respuesta a agua' y 'biosíntesis de la cutícula' (proceso alterado por la sequía; Aharoni et al, 2004a) estaban casi significativamente sobre-representadas en el conjunto de los genes inducidos (Fig. 43A; Tabla Suplementaria XXX), buscamos genes expresados diferencialmente en las plantas CCGA20ox implicados en la respuesta originada por estrés por desecación, osmótico, salino y oxidativo (Tabla 27). En el conjunto de genes expresados diferencialmente en las plantas CcGA20ox (Tabla 27) encontramos que 23 unigenes (15 de ellos relacionados con la 'respuesta a agua') estaban inducidos mientras que 11 aparecieron reprimidos. Así pues, en las plantas CcGA20ox se observó una inducción de los genes que codifican LEA5, dehidrina, delta 1-pirrolina-5-carboxilato sintasa (P5CS) y proteínasas tipo cisteína (RD19, RD21). Con anterioridad a este trabajo, no se habían descrito cambios en la expresión de genes implicados en estrés por déficit hídrico en plantas con el metabolismo de GAs modificado. La acumulación de miembros de la familia de dehidrinas y de proteínas LEA en arroz (Xu et al, 1996), girasol (Cellier et al, 1998), cebada (Zhu et al, 2000) y trigo (Sivamani et al, 2000; López et al, 2001) así como la sobre-expresión de delta 1-pirrolina-5-carboxilato sintasa en tabaco (Kavi Kishor et al, 1995) aumenta la tolerancia a la sequía. Así pues, los resultados obtenidos en este trabajo sugieren la posibilidad de que las plantas CCGA20ox también puedan mostrar una mayor tolerancia al estrés originado por déficit hídrico.

La superficie de las plantas está protegida por la cutícula, una compleja estructura lipídica compuesta por una capa externa de cera (epicuticular), que constituye una barrera protectora frente al estrés debido a diferentes factores ambientales, principalmente a sequía y patógenos (Chen et al, 2003a). De acuerdo con esta idea, el análisis transcriptómico de Populus en respuesta a estrés originado por déficit hídrico está asociado a una regulación positiva no sólo de la ontología génica de 'respuesta a agua' sino también de 'biosíntesis de cera' y 'biosíntesis de la cutícula' (Street et al, 2006). En el caso de las plantas de cítricos CcGA20ox se encontraron inducidos, además de los genes implicados en la respuesta a agua (Tabla 27), otros genes relacionados con lípidos (ej. GDSL lipasas/hidrolasas y acil-ACP tioesterasa), ceras (Wax2) y biosíntesis de la cutícula como la enzima de condensación de ácidos grasos de cadena muy larga (VLCFA) y proteínas de 
transferencia de lípidos (LTP) (Tabla 28), lo que sugiere que en estas plantas probablemente exista una modificación de la cutícula para evitar la pérdida de agua.

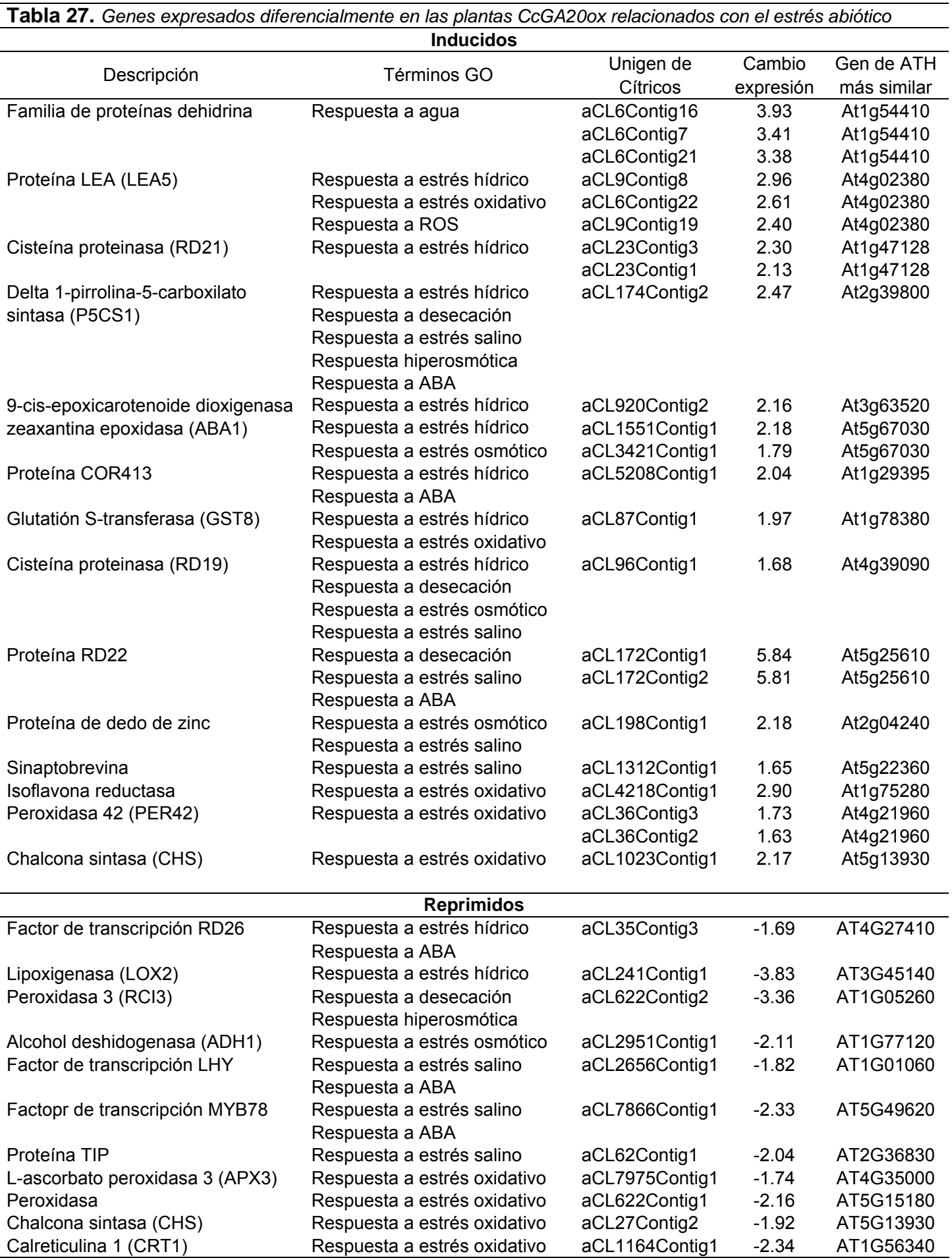

Nuestros resultados apoyan la conclusión de que la sobre-expresión del gen CcGA200x1 en cítricos produce una re-programación transcripcional que coincide parcialmente con la originada por la sequía (Street et al, 2006). Sin embargo, resulta 
importante señalar que una diferencia considerable entre la respuesta a sequía y a la sobre-expresión de GA20ox es la reducción en la fotosíntesis observada en el primer caso (Street et al, 2006), contrariamente al aumento encontrado en el segundo.

\begin{tabular}{|c|c|c|c|}
\hline Descripción & $\begin{array}{l}\text { Unigen de } \\
\text { Cítricos }\end{array}$ & $\begin{array}{l}\text { Cambio de } \\
\text { expresión }\end{array}$ & $\begin{array}{l}\text { Gen de ATH } \\
\text { más similar }\end{array}$ \\
\hline \multirow[t]{6}{*}{ GDSL lipasa/hidrolasa } & aCL2438Contig1 & 2.40 & At2g04570 \\
\hline & aCL273Contig1 & 1.67 & At5g33370 \\
\hline & aCL3133Contig2 & 1.23 & At3g16370 \\
\hline & aCL3133Contig1 & 1.17 & At3g16370 \\
\hline & aC02007G06SK_c & 0.84 & At3g16370 \\
\hline & aC05014A08SK_c & -0.95 & At5g55050 \\
\hline Acil-tioesterasa & aCL2357Contig 1 & 0.71 & At1g08510 \\
\hline \multicolumn{4}{|l|}{ Biosíntesis de glicerolípidos } \\
\hline Glicerol-3-fosfato aciltransferasa & aCL288Contig1 & 1.48 & At2g38110 \\
\hline Diacilglicerol aciltransferasa & aC04022C03SK_c & 0.85 & At3g51520 \\
\hline \multicolumn{4}{|l|}{ Biosíntesis de fosfolípidos } \\
\hline Colina-fosfato citidililtransferasa & aCL3347Contig1 & -0.70 & At2g32260 \\
\hline Inositol-3-fosfato sintasa & aCL25Contig1 & -1.34 & At2g22240 \\
\hline Fosfoetanolamina N-metiltransferasa & aCL1819Contig1 & -2.26 & At3g18000 \\
\hline \multicolumn{4}{|l|}{ Biosíntesis de glicolípidos } \\
\hline UDP-galactosa:MGDG galactosiltransferasa & aC02006F12SK_c & -0.76 & At4g00550 \\
\hline \multicolumn{4}{|c|}{ Biosíntesis de ácidos grasos de cadena muy larga (VLCFA) } \\
\hline Enzima de condensación de VLCFA (CUT1) & aCL2743Contig1 & 1.75 & At1g68530 \\
\hline Beta-ketoacil-CoA sintasa (FID) & aCL2162Contig1 & 1.45 & At2g26250 \\
\hline Beta-ketoacil-CoA sintasa & aC07007G06SK_c & 0.94 & At5g04530 \\
\hline \multicolumn{4}{|l|}{ Transporte de lípidos } \\
\hline Proteína de transferencia de lípidos 1 (LTP1) & aC02009H06SK_c & 0.69 & At2g38540 \\
\hline Proteína de transferencia de lípidos 4 (LTP4) & aCL3Contig9 & 1.45 & At5g59310 \\
\hline Proteína de transferencia de lípidos 4 (LTP4) & aCL3Contig25 & 1.44 & At5g59310 \\
\hline Proteína de transferencia de lípidos 6 (LTP6) & aCL2327Contig1 & -1.46 & At3g08770 \\
\hline \multirow[t]{6}{*}{ Proteína de transferencia de lípidos (LTP) } & aCL12Contig7 & 3.54 & At3g18280 \\
\hline & aCL12Contig9 & 2.99 & At3g18280 \\
\hline & aCL12Contig8 & 2.67 & At3g18280 \\
\hline & aCL369Contig2 & 2.06 & At3g18280 \\
\hline & aCL2301Contig1 & -1.27 & At3g18280 \\
\hline & aCL595Contig2 & -0.79 & At2g10940 \\
\hline \multicolumn{4}{|l|}{ Biosíntesis de ceras } \\
\hline Wax2 & aCL2973Contig1 & 0.99 & AT5G57800 \\
\hline
\end{tabular}

El ácido abscísico (ABA) regula el desarrollo vegetativo en respuesta al estrés causado por diversos factores ambientales como condiciones de sequía o de elevada salinidad. Bajo condiciones de estrés por déficit hídrico, el contenido en ABA aumenta e induce el cierre de los estomas, para evitar la pérdida de agua por transpiración, a través de una compleja cascada de señalización (Blatt, 2000). Aunque el contenido en ABA en las plantas CCGA20ox se desconoce, la posibilidad de un aumento del mismo no parece consistente con la observación de que tanto la apertura estomática (estimada mediante la conductancia estomática) como la tasa de transpiración se encuentran aumentadas en las hojas de las plantas transgénicas de cítricos 
(Tabla 24). Además la expresión de dos genes que codifican las enzimas clave en la biosíntesis de ABA (NCED3 y ABA2; Nambara y Marion-Poll, 2005), presentes en la micromatriz CIT1, no se vió afectada (datos no presentados); mientras que tres factores de transcripción, que responden a ABA en Arabidopsis (uno de tipo NAC y dos MYB) se encontraron reprimidos en las plantas CcGA20ox (Tabla 27). Por lo tanto, los cambios de expresión observados en los genes relacionados con estrés por déficit hídrico no parecen estar mediados por ABA en las plantas CcGA20ox.

\subsubsection{Estrés de origen biótico}

Diversos tipos de genes relacionados con el estrés producido por factores bióticos (ej. 6 quitinasas y 10 inhibidores de proteasas de tipo Kunitz) aparecieron reprimidos en las plantas CcGA20ox (Tabla Suplementaria XXVII). Las quitinasas son conocidas proteínas PR (pathogenesis-related) codificadas por familias multigénicas (Neuhaus, 1999), y su sobre-expresión en plantas transgénicas pueden aumentar la protección frente a hongos fitopatógenos (Kim et al, 2003). Nuestros resultados sugieren que una posible función de la producción de GAs en plantas de arroz infectadas con Gibberella fujikuroi, que causa una enfermedad llamada 'bakanae' que condujo al descubrimiento de las GAs (Sponsel y Hedden, 2004), podría ser la de facilitar la infección de dicho hongo por una disminución en la expresión de las quitinasas de la planta.

\subsubsection{Factores de transcripción}

Los genes que codifican factores de transcripción constituyen una parte importante del genoma de los organismos eucariotas, y la mayoría de estos genes pueden agruparse en diferentes familias génicas según el tipo de dominio de unión al DNA (Riechmann y Ratcliffe, 2000). Los factores de transcripción integran la expresión de otros genes en respuesta a diversos estímulos ambientales y estados de desarrollo, aunque se desconocen muchos de los genes regulados por los factores de transcripción. La Tabla 29 resume los cambios de expresión de los genes de cítricos que codifican posibles factores de transcripción y que muestran una expresión diferencial en las plantas CCGA20ox, 11 de ellos inducidos y 8 reprimidos.

Muchos de los factores de transcripción codificados por genes expresados diferencialmente en las plantas CCGA20ox parecen regular procesos relacionados con las alteraciones fenotípicas observadas en dichas plantas (por ejemplo, cambio en la arquitectura de la planta y resistencia a estrés). Así pues, entre los genes inducidos 
que codifican factores de transcripción encontramos los correspondientes a BEL1-like homeodomain1 (BLH1) (la mutación de este gen causa una fenotipo enano en Arabidopsis; Bhatt, 2004), a WRKY (muchos WRKY tienen funciones de regulación en respuesta a la infección por patógenos y otros tipos de estrés; Eulgem et al, 2000), a bHLH (en concreto, bHLH062, que responde a diversos tipos de estrés; Heim et al, 2003) y a YABBY.

\begin{tabular}{|c|c|c|c|}
\hline Descripción & $\begin{array}{l}\text { Unigen de } \\
\text { cítricos }\end{array}$ & $\begin{array}{l}\text { Cambio de } \\
\text { expresión }\end{array}$ & $\begin{array}{l}\text { Gen de ATH } \\
\text { más similar }\end{array}$ \\
\hline Factor de transcripción de la familia IIB (TFIIB) & aCL656Contig3 & 2.41 & At4g36650 \\
\hline Proteína con un grupo B de alta movilidad (HMGB4) & aCL138Contig4 & -1.60 & At2g17560 \\
\hline Subfamilia relacionada con kinasa CDC2 (AFC1) & aCL3136Contig1 & -6.77 & At3g53570 \\
\hline \multicolumn{4}{|l|}{ Familia de Factores de Transcripción MYB } \\
\hline Factor de transcripción de la familia Myb (MYB52) & aCL5017Contig1 & 1.94 & At1g17950 \\
\hline Factor de transcripción de la familia Myb (MYB121) & aCL2843Contig1 & -3.13 & At3g30210 \\
\hline Factor de transcripción de la familia Myb (MYB78) & aCL7866Contig1 & -2.33 & At5g49620 \\
\hline Factor de transcripción relacionado con Myb (CCA1) & aCL2656Contig1 & -1.82 & At1g01060 \\
\hline \multicolumn{4}{|l|}{ Familia de Factores de Transcripción CCAAT-HAP5 } \\
\hline Heme activated protein (HAP5c) & aCL665Contig2 & 1.92 & At1g08970 \\
\hline \multicolumn{4}{|l|}{ Familia de Factores de transcripción C2C2-YABBY } \\
\hline Factor de transcripción de la familia YABBY & aCL4648Contig1 & 1.78 & At2g26580 \\
\hline \multicolumn{4}{|l|}{ Familia de Factores de transcripción Homeobox } \\
\hline BEL1-like homeodomain 1 (BLH1) & aCL157Contig1 & 2.81 & At2g35940 \\
\hline BEL1-like homeodomain 1 (BLH1) & aCL1577Contig1 & 1.94 & At2g35940 \\
\hline Class II knotted1-like homeobox (KNAT3) & aCL1472Contig1 & 1.94 & At5g25220 \\
\hline \multicolumn{4}{|l|}{ Familia de Factores de transcripción bHLH } \\
\hline Basic helix-loop-helix (bHLH) family protein & aCL9380Contig1 & 1.68 & At3g07340 \\
\hline \multicolumn{4}{|l|}{ Familia de Factores de transcripción WRKY } \\
\hline Factor transcripción de la familia WRKY (WRKY31) & aCL1201Contig1 & 1.64 & At4g22070 \\
\hline \multicolumn{4}{|l|}{ Familia de Factores de transcripción ABI3VP1 } \\
\hline Factor de transcripción de la familia B3 (VRN1) & aCL7325Contig1 & 1.70 & At3g18990 \\
\hline \multicolumn{4}{|l|}{ Familia de Factores de transcripción bZIP } \\
\hline Factor de transcripción de la familia bZIP & aCL6889Contig1 & -5.32 & At1g08320 \\
\hline \multicolumn{4}{|l|}{ Familia de Factores de transcripción $\mathrm{C} 2 \mathrm{H} 2$} \\
\hline Factor transcripción familia dedo de zinc (SUF4) & aCL335Contig1 & -1.62 & At1g30970 \\
\hline \multicolumn{4}{|l|}{ Familia de Factores de transcripción NAC } \\
\hline Factor de transcripción de la familia NAC (RD26) & aCL35Contig3 & -1.69 & At4g27410 \\
\hline \multicolumn{4}{|l|}{ Response Regulador Gene Family } \\
\hline pseudo-response regulator 5 (APRR5) & aCL5406Contig1 & 1.60 & At5g24470 \\
\hline
\end{tabular}

En el conjunto de genes reprimidos que codifican factores de transcripción encontramos una proteína HMGB (high mobility group $B$ ) (cuya sobre-expresión en Arabidopsis altera el crecimiento de la plántula bajo diferentes condiciones de estrés; Kwak et al, 2007), un factor de transcripción de tipo NAC (RD26) (implicado en la respuesta a la desecación en Arabidopsis; Yamaguchi-Shinozaki et al, 1992) y varios miembros de la familia de factores de transcripción de tipo MYB (CCA2 y MYB78 y MYB121, que responden a estrés salino y a ABA en Arabidopsis, respectivamente; Yanhui et al, 2006). Recientemente, se ha demostrado que un gen que codifica el 
factor de transcripción tipo YABBY (YAB1) de arroz, con elevada similitud de secuencia al inducido en las plantas CCGA20ox (Tabla 29), está implicado en la regulación negativa de la biosíntesis de GA (Dai et al, 2007).

\section{CAMBIOS EN LA EXPRESIÓN GÉNICA DE ENTRENUDOS DE EXPLANTES TRATADOS CON GA}

\subsection{La aplicación de $\mathrm{GA}_{3}$ a tiempos cortos altera el transcriptoma de los entrenudos de explantes de cítricos}

Con objeto de comprender mejor cómo controlan las GAs el desarrollo de los brotes vegetativos en citrange Carrizo, se diseñó un experimento para conocer cómo se ve alterado el transcriptoma tras una aplicación de $\mathrm{GA}_{3}$ a tiempos cortos. El tratamiento con $\mathrm{GA}_{3}$ regula negativamente la expresión del gen CCGA20ox1 en cítricos, mientras que el tratamiento con paclobutrazol (PCB) tiene el efecto contrario (Vidal et al, 2003). La expresión de dicho gen se analizó, mediante RT-PCR, en entrenudos procedentes de brotes jóvenes de citrange Carrizo, en el mismo estadío de desarrollo que los utilizados en el análisis del transcriptoma anteriormente descrito, cultivados en presencia de $10 \mu \mathrm{M} \mathrm{GA}_{3}$ y recogidos 6,12 y $24 \mathrm{~h}$ después del tratamiento con $\mathrm{GA}_{3}$. Los resultados mostraron una clara reducción de los niveles de transcritos de CCGA200x1 tras $24 \mathrm{~h}$ de tratamiento con $\mathrm{GA}_{3}$ (Fig. 45), lo que indica que $\mathrm{GA}_{3}$ había sido transportado y metabolizado eficientemente en los explantes tratados con $\mathrm{GA}_{3}$. Por otro lado, el tratamiento con PCB aumentó ligeramente los niveles de expresión del gen CCGA20ox1 (Fig. 45), aunque el efecto no fue tan claro como el obsevado con $\mathrm{GA}_{3}$. Por este motivo, en el análisis del transcriptoma se utilizaron entrenudos procedentes de explantes recogidos tras $24 \mathrm{~h}$ de la aplicación de $\mathrm{GA}_{3}$.

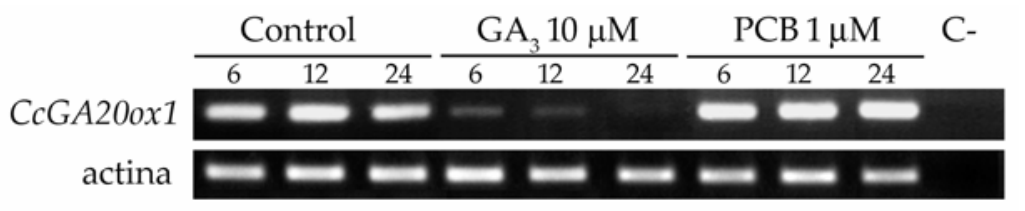

Fig. 45. Análisis de la expresión del gen CCGA20ox1 en entrenudos de citrange Carrizo procedentes de explantes recogidos tras 6,12 y $24 \mathrm{~h}$ del tratamiento con $10 \mu \mathrm{M}$ de $\mathrm{GA}_{3}$ o con $1 \mu \mathrm{M}$ de PCB. Los niveles de transcrito se determinaron mediante RT-PCR semicuantitativa, tal como se describe en Materiales y Métodos, utilizando una actina de cítricos (CX289161) como control interno. 
El diseño del experimento de análisis del transcriptoma de entrenudos de citrange Carrizo procedentes de explantes recogidos a las $24 \mathrm{~h}$ del tratamiento con $10 \mu \mathrm{M} \mathrm{GA}{ }_{3}$ consistió en dos comparaciones directas, tiempo $24 \mathrm{~h}$ frente a tiempo $0 \mathrm{~h}$ y tiempo $24 \mathrm{~h}$ con tratamiento de $\mathrm{GA}_{3}$ frente a tiempo $0 \mathrm{~h}$, de modo que fuera posible estimar el efecto tiempo y el efecto tratamiento (Fig. 46). Se realizaron 4 réplicas biológicas, cada una de ellas formada por entrenudos procedentes de 5 explantes, para cada una de las tres condiciones: tiempo $0 \mathrm{~h}$, tiempo $24 \mathrm{~h}$ y tiempo $24 \mathrm{~h}$ con tratamiento de $\mathrm{GA}_{3}$. El RNA de las réplicas biológicas correspondientes al tiempo $0 \mathrm{~h}$ se juntó y se utilizó como material de referencia (Fig. 46).

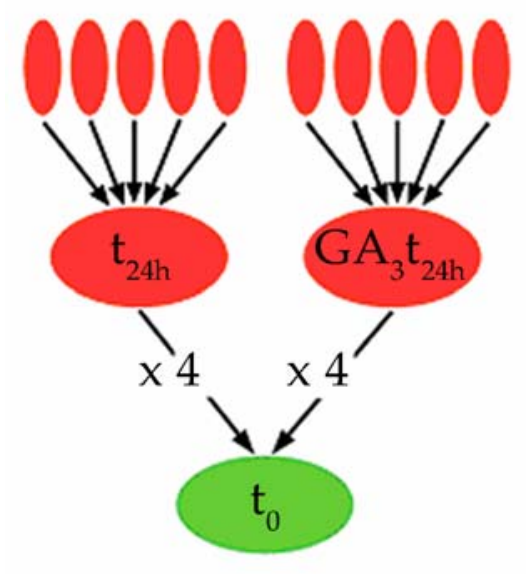

Fig. 46. Diseño del experimento. El efecto de la aplicación de $\mathrm{GA}_{3}$ en el transcriptoma de entrenudos procedentes de brotes en desarrollo de citrange Carrizo se obtuvo de la doble comparación 'muestras procedentes de entrenudos recogidos a las $24 \mathrm{~h}$ de la aplicación de $\mathrm{GA}_{3}$, marcadas con Cy5, con muestras control, marcadas con Cy3' y 'muestras procedentes de entrenudos recogidos a las 24 h, marcadas con Cy5, con muestras control, marcadas con Cy3'.

La identificación de los genes expresados diferencialmente se realizó mediante el análisis SAM (Tusher et al, 2001). Los genes regulados por GAs se identificaron utilizando un límite de FDR del $5 \%$ y un valor de cambio de expresión de al menos 1.6. De este modo, se identificaron 123 ESTs significativamente reguladas en respuesta al tratamiento de $\mathrm{GA}_{3}$ que correspondieron a 75 unigenes, 26 inducidos y 49 reprimidos (Tabla 30). Tal como sucedía en el análisis transcriptómico de las plantas transgénicas, un $14.7 \%$ de los genes expresados diferencialmente (11 genes) no mostraron similitud de secuencia significativa con ninguna proteína de Arabidopsis (Tabla 30). En este caso también se realizó un análisis de enriquecimiento funcional con FatiGo (Al-Shahrour et al, 2004) pero no se encontró ninguna categoría significativamente sobre-representada. Los genes expresados diferencialmente tras el tratamiento con $\mathrm{GA}_{3}$ se clasificaron en categorías MIPS con la intención de 
comprender su posible función biológica (Tabla Suplementaria XXXII para los genes inducidos y Tabla Suplementaria XXXIII para los reprimidos).

Tal como sucedía en las plantas CcGA20ox (Tabla Suplementaria XXVII), diversos genes implicados en la síntesis de proteínas (dos que codifican proteínas ribosomales y uno que codifica un factor de iniciación de la traducción) también aparecieron reprimidos tras la aplicación de $\mathrm{GA}_{3}$ (Tabla 30). Estos resultados apoyan la idea de que las GAs parecen inducir una traducción diferencial de las proteínas. Sin embargo, en contraste con las plantas CCGA20ox, no se detectó un aumento en los transcritos de RuBisCo tras $24 \mathrm{~h}$ de la aplicación de $\mathrm{GA}_{3}$ utilizando explantes de cítricos cultivados in vitro, así como de ningún otro gen implicado en la fijación de carbono. Esto significa que el aumento de la expresión de los genes relacionados con la fotosíntesis y la fijación de carbono en las plantas CCGA20ox fue, probablemente, resultado de un efecto a largo plazo de la modificación de los niveles de GAs en las plantas transgénicas.

\begin{tabular}{|c|c|c|c|c|c|}
\hline \multicolumn{6}{|c|}{ Inducidos } \\
\hline $\begin{array}{l}\text { Unigen de } \\
\text { Cítricos }\end{array}$ & $\begin{array}{c}\text { Cambio } \\
\text { expresión }\end{array}$ & $\begin{array}{c}\text { Valor } q \\
(\%)\end{array}$ & & Gen de Arabidopsis más similar & Valor $E$ \\
\hline aCL32Contig2 & 4.16 & 0.211 & At1g19640 & Ácido jasmónico carboxil metiltransferasa (JMT) & $3 \mathrm{E}-79$ \\
\hline aCL32Contig1 & 2.99 & $0.211-1.137$ & At1g19640 & Ácido jasmónico carboxil metiltransferasa (JMT) & $2 \mathrm{E}-90$ \\
\hline aCL25Contig1 & 2.79 & 0.211 & At2g22240 & Inositol-3-fosfato sintasa (IPS 2) & 0 \\
\hline aCL76Contig1 & 2.55 & $0.211-3.399$ & At4g11650 & Proteína similar a osmotina (OSM34) & $3 E-78$ \\
\hline aCL2301Contig1 & 2.42 & 0.211 & At3g18280 & Proteína de transferencia de lípidos (LTP) & $7 \mathrm{E}-27$ \\
\hline aCL5030Contig1 & 2.29 & 1.628 & At4g11650 & Proteína similar a osmotina (OSM34) & $3 E-86$ \\
\hline aCL5853Contig1 & 2.12 & 0.600 & At1g30820 & CTP sintasa & $1 \mathrm{E}-136$ \\
\hline aCL3705Contig1 & 1.87 & 0.211 & At2g01570 & Proteína de respuesta a GAs (RGA1) & 0 \\
\hline aCL3827Contig2 & 1.86 & 0.211 & At1g04680 & Pectato liasa & $1 \mathrm{E}-102$ \\
\hline aCL39Contig3 & 1.80 & 0.211 & & & \\
\hline aCL39Contig2 & 1.79 & 0.211 & & & \\
\hline aCL23Contig1 & 1.75 & $0.211-1.137$ & At1g47128 & Cisteína proteinasa (RD21A) & 0 \\
\hline aCL37Contig2 & 1.74 & 0.211 & At2g32210 & Proteína de función desconocida & $2 \mathrm{E}-11$ \\
\hline aCL39Contig1 & 1.70 & $0.211-1.628$ & & & \\
\hline aCL23Contig3 & 1.68 & 0.211 & At1g47128 & Cisteína proteinasa (RD21A) & 0 \\
\hline aCL12Contig4 & 1.67 & 0.211 & At5g26330 & Plastocianina & $2 \mathrm{E}-20$ \\
\hline aCL5Contig2 & 1.66 & 0.211 & & & \\
\hline aCL6Contig7 & 1.65 & $1.628-2.236$ & At1g54410 & Dehidrina & $8 \mathrm{E}-09$ \\
\hline aCL5Contig3 & 1.64 & $0.597-0.600$ & At5g47560 & Transportador de malato & 0 \\
\hline aCL2773Contig1 & 1.64 & 0.211 & At2g42590 & Proteína 14-3-3 (GRF12) & $1 \mathrm{E}-113$ \\
\hline aCL6Contig16 & 1.64 & $0.958-3.399$ & At1g54410 & Dehidrina & $8 \mathrm{E}-09$ \\
\hline aCL5Contig4 & 1.62 & 1.628 & At5g05580 & Omega-3 ácido graso desaturasa (FAD8) & $6 \mathrm{E}-60$ \\
\hline aCL129Contig1 & 1.61 & 1.138 & At2g03440 & Proteína relacionada con nodulina & $6 \mathrm{E}-07$ \\
\hline aCL5Contig7 & 1.61 & 0.852 & At1g05870 & Proteína de función desconocida & $2 \mathrm{E}-49$ \\
\hline aCL6Contig21 & 1.61 & 1.628 & At1g54410 & Dehidrina & $8 \mathrm{E}-09$ \\
\hline aCL4194Contig1 & 1.60 & 1.138 & At1g77280 & Proteína kinasa & 0 \\
\hline
\end{tabular}




\begin{tabular}{|c|c|c|c|c|c|}
\hline \multicolumn{6}{|c|}{ Reprimidos } \\
\hline aC08007H11 & -4.54 & 0.211 & & & \\
\hline aCL190Contig4 & -3.78 & 0.211 & At1g17860 & Proteína de la familia Kunitz & $4 \mathrm{E}-26$ \\
\hline aCL10Contig1 & -2.04 & 0.211 & At3g12500 & Endoquitinasa básica & $3 \mathrm{E}-87$ \\
\hline aCL251Contig1 & -2.02 & 0.211 & & & \\
\hline aCL10Contig3 & -1.95 & 0.211 & At3g12500 & Endoquitinasa básica & $1 \mathrm{E}-100$ \\
\hline aCL10Contig9 & -1.94 & $0.211-2.356$ & At3g12500 & Endoquitinasa básica & $3 E-82$ \\
\hline aC08001B11 & -1.86 & 0.211 & At1g09630 & Proteína Ras de unión a GTP & $5 \mathrm{E}-25$ \\
\hline aCL1Contig33 & -1.81 & 1.483 & At1g17860 & Proteína de la familia Kunitz & $3 \mathrm{E}-26$ \\
\hline aCL11Contig1 & -1.81 & $0.211-1.483$ & At5g06740 & Proteína lectina kinasa & $8 \mathrm{E}-14$ \\
\hline aC08008G03 & -1.81 & 0.211 & At4g17380 & Proteína MSH2 (MSH2) & $3 \mathrm{E}-18$ \\
\hline aC08001H03 & -1.79 & 0.211 & At4g09340 & Proteína SPRY & $2 \mathrm{E}-20$ \\
\hline aCL10Contig7 & -1.77 & $0.363-1.628$ & At3g12500 & Endoquitinasa básica & $1 \mathrm{E}-100$ \\
\hline aCL2152Contig1 & -1.77 & 0.211 & At1g10840 & Factor 3 de iniciación de la traducción & $1 \mathrm{E}-164$ \\
\hline aC08015B11 & -1.74 & 0.211 & & & \\
\hline aCL11Contig4 & -1.73 & 0.211 & At5g03140 & Proteína lectina kinasa & $3 \mathrm{E}-08$ \\
\hline aCL10Contig4 & -1.72 & $0.211-1.483$ & At3g12500 & Endoquitinasa básica & $5 \mathrm{E}-87$ \\
\hline aCL4076Contig1 & -1.72 & 0.211 & At2g20340 & Tirosina descarboxilasa & $1 \mathrm{E}-170$ \\
\hline aCL5231Contig1 & -1.71 & 0.211 & & & \\
\hline aCL7529Contig1 & -1.71 & 0.211 & At3g29450 & Proteína de función desconocida & $4 \mathrm{E}-09$ \\
\hline aCL2797Contig2 & -1.68 & 0.211 & At1g04300 & Proteína mefrina & $3 \mathrm{E}-57$ \\
\hline aCL1Contig10 & -1.68 & 1.628 & At1g17860 & Proteína de la familia Kunitz & 9E-24 \\
\hline aCL4111Contig1 & -1.68 & 0.211 & At2g42710 & Proteína ribosomal L1 & $2 \mathrm{E}-64$ \\
\hline aC03002C05 & -1.68 & 0.211 & At1g78280 & Factor de transcripción jumonji (jmjC) & $6 \mathrm{E}-12$ \\
\hline aC08013E08 & -1.67 & 0.211 & & & \\
\hline aCL7581Contig1 & -1.67 & 0.211 & At1g62710 & Enzima vacuolar (beta-VPE) & $2 \mathrm{E}-32$ \\
\hline aC02013A07 & -1.67 & 0.211 & At5g55760 & Regulador transcripcional Sir2 & $1 \mathrm{E}-103$ \\
\hline aCL6631Contig1 & -1.66 & 0.211 & At2g42730 & Proteína F-box & $2 \mathrm{E}-19$ \\
\hline aCL829Contig1 & -1.66 & 0.211 & At1g70540 & Inhibidor de invertasa & $4 \mathrm{E}-20$ \\
\hline aCL8391Contig1 & -1.66 & 0.211 & At5g52590 & Proteína RabGAP/TBC & $1 \mathrm{E}-129$ \\
\hline aCL7155Contig1 & -1.66 & 0.211 & At3g52500 & Aspartil proteasa & $1 \mathrm{E}-07$ \\
\hline aCL7099Contig1 & -1.66 & 0.211 & At3g47160 & Proteína de función desconocida & $4 \mathrm{E}-46$ \\
\hline aCL705Contig1 & -1.65 & 0.597 & At3g26740 & Proteína de respuesta a luz CCR & $6 \mathrm{E}-30$ \\
\hline aC02009D08 & -1.65 & 0.363 & At2g26790 & Pentatricopéptido (PPR) & $1 \mathrm{E}-26$ \\
\hline aCL1656Contig1 & -1.65 & 0.211 & At1g49320 & Proteína con dominio BURP & $1 \mathrm{E}-57$ \\
\hline $\mathrm{aC} 16011 \mathrm{H} 07$ & -1.65 & 0.211 & At1g01490 & Proteína de unión a metales pesados & $9 \mathrm{E}-08$ \\
\hline aC02019F03 & -1.64 & 0.211 & & & \\
\hline aC02002A01 & -1.64 & 0.211 & At1g21410 & Proteína F-box & $1 \mathrm{E}-07$ \\
\hline aCL9011Contig1 & -1.64 & 0.211 & At5g24560 & Proteína F-box & $2 \mathrm{E}-36$ \\
\hline aC05004G01 & -1.64 & 0.211 & & & \\
\hline aCL5247Contig1 & -1.64 & 0.211 & At3g05590 & Proteína ribosomal 60S (RPL18B) & $1 \mathrm{E}-41$ \\
\hline aCL16Contig1 & -1.64 & $0.211-0.363$ & At5g54770 & Tiazol (ARA6) & $1 \mathrm{E}-151$ \\
\hline aC02019D11 & -1.64 & 0.211 & At4g22720 & Glicoproteasa M22 & $2 \mathrm{E}-20$ \\
\hline aCL3781Contig1 & -1.63 & 0.852 & At5g42740 & Glucosa-6-fosfato isomerasa (PGIC) & $1 \mathrm{E}-131$ \\
\hline aC16011E01 & -1.62 & 0.726 & At5g65690 & Fosfoenolpiruvato carboxikinasa (ATP) & $2 \mathrm{E}-11$ \\
\hline aC01009G11 & -1.62 & 0.211 & At5g48790 & Proteína de función desconocida & $8 \mathrm{E}-56$ \\
\hline aCL3172Contig1 & -1.62 & 0.211 & At5g41990 & Proteína kinasa & $1 \mathrm{E}-60$ \\
\hline aCL7137Contig1 & -1.62 & 0.211 & At5g59380 & Proteína con dominio de unión a metil-CpG & $3 \mathrm{E}-06$ \\
\hline aCL7667Contig1 & -1.61 & 0.211 & At2g35680 & Fosfatasa & $1 \mathrm{E}-18$ \\
\hline aC08013F08 & -1.61 & 0.211 & At3g14290 & 20S proteasoma (PAE2) & $2 \mathrm{E}-69$ \\
\hline
\end{tabular}


El resultado más destacado obtenido con los entrenudos tratados con $\mathrm{GA}_{3}$ fue que la mayoría de los genes expresados diferencialmente estaban implicados en estrés de origen tanto abiótico como biótico (Tabla 30), efecto que también se observó en el análisis transcriptómico de las plantas CCGA20ox. En el caso de los genes inducidos, se encontró que de un total de 22 genes, 14 de ellos codifican proteínas implicadas en la respuesta a estrés hídrico (dehidrinas y cisteína proteinasa), en la percepción y en la respuesta a la temperatura (inositol-3-fosfato sintasa y omega-3 ácido graso desaturasa), y en la respuesta de la planta a estímulos bióticos y defensa (proteína similar a osmotina). Además, los genes correspondientes a dos grupos de proteínas implicadas en los mecanismos de defensa de la planta (endoquitinasas básicas y proteínas de la familia Kunitz) estaban reprimidos, tal como sucedía en las plantas CCGA200x.

Las proteínas DELLA están localizadas en el núcleo y son reguladores negativos de la transducción de señal de GAs cuya degradación está promovida por las propias GAs (Fleet and Sun, 2005). Recientemente, se ha propuesto que las proteínas DELLA son integradores de la respuesta a señales ambientales en Arabidopsis (Achard et al, 2006). De acuerdo con esta idea, sugerimos que la sobrerepresentación de genes de respuesta a estrés hídrico (Tabla Suplementaria XXX y Fig. 43A) así como la expresión diferencial de otros genes relacionados con el estrés de origen biótico (Tabla Suplementaria XXVII y XXXIII) y abiótico (Tabla 27) puede ser consecuencia de un descenso en el contenido de proteínas DELLA causado por los niveles elevados de GAs. No obstante, esta hipótesis debe ser confirmada comprobando los niveles de proteínas DELLA en las plantas CCGA20ox. Desafortunadamente, todavía no se conoce la complejidad de la familia DELLA en cítricos, ni se dispone de herramientas moleculares para evaluar los niveles de proteínas DELLA en las plantas CCGA20ox o en respuesta a estrés en cítricos. En este sentido, resulta interesante destacar que el unigen de cítricos aCL3705Contig1, que codifica una proteína similar a RGA1 de Arabidopsis (At2g01570), no mostró cambios de expresión en las plantas CCGA20ox pero se observó una inducción significativa en los entrenudos tratados con $\mathrm{GA}_{3}$ (Tabla Suplementaria XXXII). Así pues, el gen RGA1 de cítricos parece estar regulado positivamente a nivel de mRNA tras la aplicación a tiempos cortos de GAs, de acuerdo con los resultados obtenidos previamente con el gen OsGAl de arroz (Ogawa et al, 2000). 


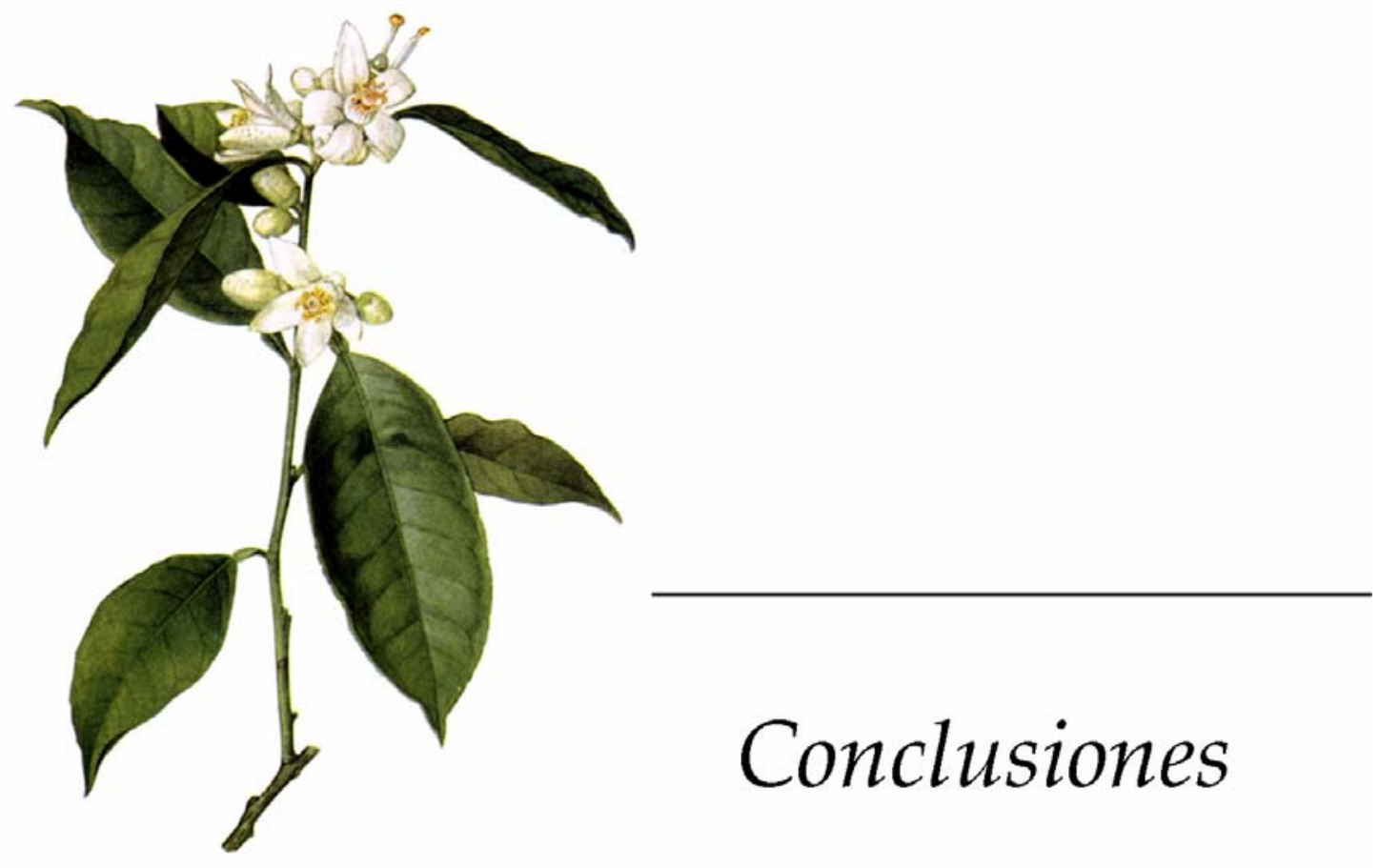





\section{CONCLUSIONES}

1. La construcción de la genoteca de cDNA Veg1, la generación de 1,689 ESTs y el análisis funcional de dicha colección permitió caracterizar los componentes de la cadena de transporte electrónico y los complejos antena de captación de luz en cítricos. El análisis de los datos de expresión puso de manifiesto dos grupos de genes Lhc; uno que codifica proteínas Lhc abundantes, cuya expresión fue diferencial en los tejidos vegetativos, y otro que codifica proteínas Lhc poco abundantes, cuya expresión sólo se detectó en los tejidos vegetativos bajo condiciones de estrés. Este patrón de expresión parece indicar una regulación distinta de los dos grupos de genes $L h c$.

2. El análisis funcional de la colección de 85,965 ESTs del Proyecto de Genómica Funcional de Cítricos (CFGP) permitió identificar la mayoría de los genes del metabolismo de isoprenoides y flavonoides en cítricos. La mayor parte de los genes de biosíntesis de fitohormonas derivadas de isoprenoides, como giberelinas, brasinosteroides y ácido abscísico no habían sido caracterizados antes en cítricos. Por otro lado, la identificación de los genes de biosíntesis de monoterpenos y sesquiterpenos, responsables del aroma tanto de las hojas como del fruto, mostró que la familia de terpeno sintasas en cítricos es una de las más amplias y diversas en plantas.

3. Los datos de expresión obtenidos en la caracterización técnica de la micromatriz CIT1 demostraron que los resultados derivados de la plataforma de micromatrices generada en el CFGP son reproducibles.

4. El análisis global de la expresión génica de diferentes tejidos de cítricos mediante la micromatriz CIT1 mostró que la raíz es el órgano con un mayor número de genes expresado diferencialmente, seguida de los tejidos reproductivos y los vegetativos, lo que posiblemente refleja la naturaleza más especializada de la raíz y de los órganos reproductivos.

5. El aumento del contenido de GAs, producido por la sobre-expresión del gen CCGA20ox1 produjo una reorganización del transcriptoma en los entrenudos de citrange Carrizo. En este trabajo, se describe por primera vez que, plantas con un contenido elevado de GAs poseen una inducción global de los genes implicados en la fotosíntesis y en el ciclo de Calvin. Esta manipulación genética 
del metabolismo de GAs está relacionada con un aumento en la capacidad de fijación fotosintética de $\mathrm{CO}_{2}$ de las plantas transgénicas. La represión general de los genes relacionados con la síntesis de proteínas y con la biogénesis de ribosomas, que no había sido descrita previamente, sugiere que dichos procesos también están regulados por GAs.

6. El análisis del transcriptoma de entrenudos tras $24 \mathrm{~h}$ de aplicación de $\mathrm{GA}_{3}$ mostró pocos cambios. La aplicación a corto plazo de $\mathrm{GA}_{3}$ no tuvo efecto sobre la fotosíntesis, por lo que la activación transcripcional observada en las plantas transgénicas es, probablemente, el resultado de una adaptación a largo plazo a la modificación del contenido de GAs. Por el contrario, la inducción de genes relacionados con estrés de origen abiótico y la represión de genes implicados en estrés de origen biótico fue observada en ambos casos, lo que sugiere que la regulación de la expresión de estos genes debe ser un efecto temprano del modo de acción de GAs en cítricos. 


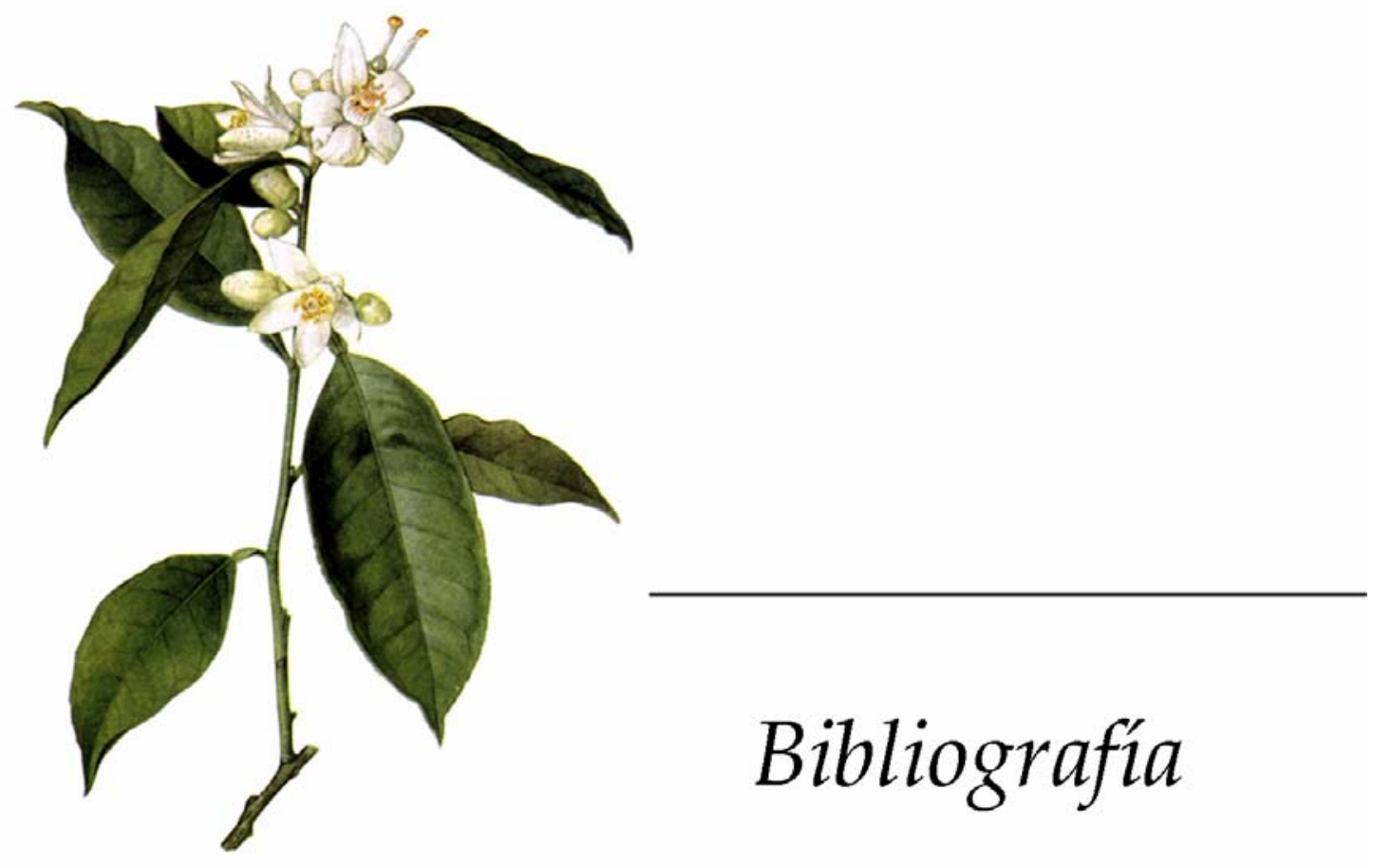





\section{BIBLIOGRAFÍA}

Aarts MG, Keijzer CJ, Stiekema WJ, Pereira A (1995) Molecular characterization of the CER1 gene of Arabidopsis involved in epicuticular wax biosynthesis and pollen fertility. Plant Cell 7: 2115-2127

Achard P, Cheng H, De Grauwe L, Decat J, Schoutteten H, Moritz T, Van Der Straeten D, Peng J, Harberd NP (2006) Integration of plant responses to environmentally activated phytohormonal signals. Science 5757: 91-94

Adams MD, Kelley JM, Gocayne JD, Dubnick M, Polymeropoulos MH, Xiao H, Merril CR, Wu A, Olde B, Moreno RF, et al (1991) Complementary DNA sequencing: expressed sequence tags and human genome project. Science 252: $1651-1656$

Agustí M (2000) Citricultura. Ed. Mundi-Prensa, Madrid, España

Agustí M, Zaragoza S, Bleiholder H, Buhr L, Hack H, Klose R, Stauß R (1995) Escala $\mathrm{BBCH}$ para la descripción de los estadios fenológicos del desarrollo de los agrios (Gén. Citrus). Levante Agrícola 332: 189-199

Aharoni A, Dixit S, Jetter R, Thoenes E, van Arkel G, Pereira A (2004a) The SHINE clade of AP2 domain transcription factors activates wax biosynthesis, alters cuticle properties, and confers drought tolerance when overexpressed in Arabidopsis. Plant Cell 16: 2463-2480

Aharoni A, Giri AP, Verstappen FW, Bertea CM, Sevenier R, Sun Z, Jongsma MA, Schwab W, Bouwmeester HJ (2004b) Gain and loss of fruit flavor compounds produced by wild and cultivated strawberry species. Plant Cell 16: 3110-3131

Ainsworth EA, Rogers A, Vodkin LO, Walter A, Schurr U (2006) The effects of elevated $\mathrm{CO}_{2}$ concentration on soybean gene expression. An analysis of growing and mature leaves. Plant Physiol 142: 135-147

Alba R, Fei Z, Payton P, Liu Y, Moore SL, Debbie P, Cohn J, D'Ascenzo M, Gordon JS, Rose JK, et al (2004) ESTs, cDNA microarrays, and gene expression profiling: tools for dissecting plant physiology and development. Plant J 39: 697-714

Alba R, Payton P, Fei Z, McQuinn R, Debbie P, Martin GB, Tanksley SD, Giovannoni J (2005) Transcriptome and selected metabolite analyses reveal multiple points of ethylene control during tomato fruit development. Plant Cell 17: $2954-2965$

Alexandrov NN, Troukhan ME, Brover VV, Tatarinova T, Flavell RB, Feldmann KA (2006) Features of Arabidopsis genes and genome discovered using full-length cDNAs. Plant Mol Biol 60: 69-85 
Allemeersch J, Durinck S, Vanderhaeghen R, Alard P, Maes R, Seeuws K, Bogaert T, Coddens K, Deschouwer K, Van Hummelen P, et al (2005) Benchmarking the CATMA microarray. A novel tool for Arabidopsis transcriptome analysis. Plant Physiol 137: 588-601

Al-Shahrour F, Díaz-Uriarte R, Dopazo J (2004) FatiGO: a web tool for finding significant associations of Gene Ontology terms with groups of genes. Bioinformatics 20: 578-580

Altschul SF, Madden TL, Schäffer AA, Zhang J, Zhang Z, Miller W, Lipman DJ (1997) Gapped BLAST and PSI-BLAST: a new generation of protein database search programs. Nucleic Acids Res 25: 3389-3402

Ancillo G, Gadea J, Forment J, Guerri J, Navarro L (2007) Class prediction of closely related plant varieties using gene expression profiling. J Exp Bot 58: 1927-1933

Andersen JR, Lübberstedt T (2003) Functional markers in plants. Trends Plant Sci 8: 554-560

Arabidopsis Genome Initiative (2000) Analysis of the genome sequence of the flowering plant Arabidopsis thaliana. Nature 408: 796-815

Arimura G, Huber DP, Bohlmann J (2004) Forest tent caterpillars (Malacosoma disstria) induce local and systemic diurnal emissions of terpenoid volatiles in hybrid poplar (Populus trichocarpa $x$ deltoides): cDNA cloning, functional characterization, and patterns of gene expression of (-)-germacrene $D$ synthase, PtdTPS1. Plant J 37: 603-616

Arondel V, Vergnolle C, Cantrel C, Kader JC (2000) Lipid transfer proteins are encoded by a small multigene family in Arabidopsis thaliana. Plant Sci 157: 112

Arumuganathan K, Earle ED (1991) Nuclear DNA content of some important plant species. Plant Mol Biol Rep 9:208-218

Ashburner M, Ball CA, Blake JA, Botstein D, Butler H, Cherry JM, Davis AP, Dolinski K, Dwight SS, Eppig JT, et al (2000) Gene Ontology: tool for the unification of biology. The Gene Ontology Consortium. Nat Genet 25: 25-29

Audic S, Claverie JM (1997) The significance of digital gene expression profiles. Genome Res 7: 986-995

Bajguz A, Tretyn A (2003) The chemical characteristic and distribution of brassinosteroids in plants. Phytochemistry 62: 1027-1046

Barber GA (1962) Enzymatic glycosylation of quercetin to rutin. Biochemistry 25: 463468 
Barkley NA, Roose ML, Krueger RR, Federici CT (2006) Assessing genetic diversity and population structure in a citrus germplasm collection utilizing simple sequence repeat markers (SSRs). Theor Appl Genet 112: 1519-1531

Bateman A, Coin L, Durbin R, Finn RD, Hollich V, Griffiths-Jones S, Khanna A, Marshall M, Moxon S, Sonnhammer EL, et al (2004) The Pfam protein families database. Nucleic Acids Res 1: 138-141

Ben-Cheikh W (1997a) Giberelinas y regulación del desarrollo en cítricos. Influencia de la polinización y brotación sobre la abscisión de frutos. Efecto del viroide de la exocortis y la temperatura sobre el crecimiento del tallo. Tesis Doctoral, Escuela Técnica Superior de Ingenieros Agrónomos, Universidad Politécnica de Valencia.

Ben-Cheikh W, Pérez-Botella J, Tadeo FR, Talón M, Primo-Millo E (1997b) Pollination increases gibberellin levels in developing ovaries of seeded varieties of Citrus. Plant Physiol 114: 557-564

Benjamini Y, Hochberg Y (1995) Controlling the false discovery rate: a practical and powerful approach to multiple testing. J R Statist Soc 57: 289-300

Bhatt AM, Etchells JP, Canales C, Lagodienko A, Dickinson H (2004) VAAMANA-a BEL1-like homeodomain protein, interacts with KNOX proteins BP and STM and regulates inflorescence stem growth in Arabidopsis. Gene 17: 103-111

Biemelt S, Tschiersch H, Sonnewald U (2004) Impact of altered gibberellin metabolism on biomass accumulation, lignin biosynthesis, and photosynthesis in transgenic tobacco plants. Plant Physiol 135: 254-265

Birnbaum K, Jung JW, Wang JY, Lambert GM, Hirst JA, Galbraith DW, Benfey PN (2005) Cell type-specific expression profiling in plants via cell sorting of protoplasts from fluorescent reporter lines. Nat Methods 2: 615-619

Birnbaum K, Shasha DE, Wang JY, Jung JW, Lambert GM, Galbraith DW, Benfey PN (2003) A gene expression map of the Arabidopsis root. Science 302: 19561960

Bishop GJ, Nomura T, Yokota T, Harrison K, Noguchi T, Fujioka S, Takatsuto S, Jones JDG, Kamiya Y (1999) The tomato DWARF enzyme catalyses C-6 oxidation in brassinosteroid biosynthesis. Proc Natl Acad Sci USA 96: 17611766

Blatt MR (2000) Cellular signaling and volume control in stomatal movements in plants. Annu Rev Cell Dev Biol 16: 221-241

Boguski MS, Lowe TM, Tolstoshev CM (1993) dbEST-database for expressed sequence tags. Nat Genet 4: 332-333 
Bohlmann J, Meyer-Gauen G, Croteau R (1998) Plant terpenoid synthases: molecular biology and phylogenetic analysis. Proc Natl Acad Sci USA 95: 41264133

Bonaldo MF, Lennon G, Soares MB (1996) Normalization and subtraction: two approaches to facilitate gene discovery. Genome Res 6: 791-806

Borevitz JO, Ecker JR (2004) Plant genomics: the third wave. Annu Rev Genomics Hum Genet 5: 443-477

Brady SM, Orlando DA, Lee JY, Wang JY, Koch J, Dinneny JR, Mace D, Ohler U, Benfey PN (2007) A high-resolution root spatiotemporal map reveals dominant expression patterns. Science 318: 801-806

Bulley SM, Wilson FM, Hedden P, Phillips AL, Croker SJ, James DJ (2005) Modification of gibberellin biosynthesis in the grafted apple scion allows control of tree height independent of the rootstock. Plant Biotechnol J 3: 215-223

Busch W, Lohmann JU (2007) Profiling a plant: expression analysis in Arabidopsis. Curr Opin Plant Biol 10: 136-141

Cao D, Cheng H, Wu W, Soo HM, Peng J (2006) Gibberellin mobilizes distinct DELLA-dependent transcriptomes to regulate seed germination and floral development in Arabidopsis. Plant Physiol 142: 509-525

Casson S, Spencer M, Walker K, Lindsey K (2005) Laser capture microdissection for the analysis of gene expression during embryogenesis of Arabidopsis. Plant $J$ 42: $111-123$

Causton HC, Quackenbush J, Brazma A (2003) Microarray gene expression data analysis: a beginner's guide. Blackwell Pub. Oxford, UK. 24-25.

Cellier F, Conejero G, Breitler JC, Casse F (1998) Molecular and physiological responses to water deficit in drought-tolerant and drought-sensitive lines of sunflower. Accumulation of dehydrin transcripts correlates with tolerance. Plant Physiol 116: 319-328

Cercós M, Soler G, Iglesias DJ, Gadea J, Forment J, Talon M (2006) Global analysis of gene expression during development and ripening of citrus fruit flesh. A proposed mechanism for citric acid utilization. Plant Mol Biol 62: 513527

Chen C, Gmitter FG (2008) Citrus EST characterization and integrated genome mapping. In Plant \& Animal Genomes XVI Conference. Town \& Country Convention Center. San Diego, CA. USA

Chen X, Goodwin SM, Boroff VL, Liu X, Jenks MA (2003a) Cloning and characterization of the WAX2 gene of Arabidopsis involved in cuticle membrane and wax production. Plant Cell 15: 1170-1185 
Chen F, Tholl D, D'Auria JC, Farooq A, Pichersky E, Gershenzon J (2003b) Biosynthesis and emission of terpenoid volatiles from Arabidopsis flowers. Plant Cell 15: 481-494

Childs KL, Hamilton JP, Zhu W, Ly E, Cheung F, Wu H, Rabinowicz PD, Town CD, Buell CR, Chan AP (2007) The TIGR Plant Transcript Assemblies database. Nucleic Acids Res 35: 846-851

Choe S, Dilkes BP, Fujioka S, Takatsuto S, Sakurai A, Feldmann KA (1998) The DWF4 gene of Arabidopsis encodes a cytochrome P450 that mediates multiple 22alpha-hydroxylation steps in brassinosteroid biosynthesis. Plant Cell 10: 231243

Chou HH, Holmes MH (2001) DNA sequence quality trimming and vector removal. Bioinformatics 17: 1093-1104

Clark AM, Bohnert HJ (1999) Cell-specific expression of genes of the lipid transfer protein family from Arabidopsis thaliana. Plant Cell Physiol 40: 69-76

Clarke B, Rahman S (2005) A microarray analysis of wheat grain hardness. Theor Appli Genet 110: 1259-1267

Close TJ, Wanamaker S, Lyon M, Mei G, Davies C, Roose ML (2006) A GeneChip ${ }^{\circledR}$ for Citrus. In Plant \& Animal Genomes XIV Conference. Town \& Country Convention Center. San Diego, CA. USA

Close TJ, Wanamaker S, Lyon M, Roose ML (2007) HarvEST: A portable and companion online browser for genome research. In Plant \& Animal Genomes XV Conference. Town \& Country Convention Center. San Diego, CA. USA

Clouse SD (2002) Brassinosteroids. In: Somerville CR, Meyerowitz EM (ed) The Arabidopsis Book. American Society of Plant Biologists, Rockville, MD, USA

Coles JP, Phillips AL, Croker SJ, García-Lepe R, Lewis MJ, Hedden P (1999) Modification of gibberellin production and plant development in Arabidopsis by sense and antisense expression of gibberellin 20-oxidase genes. Plant $\mathrm{J}$ 17: 547-556

Cosgrove DJ (2005) Growth of the plant cell wall. Nat Rev Mol Cell Biol 6: 850-861

Cramer MD, Nagel OW, Lips SH, Lambers H (1995) Reduction, assimilation and transport of $\mathrm{N}$ in normal and gibberellin-deficient tomato plants. Physiol Plant 95: $347-354$

Croteau R, Kutchan T, Lewis N (2000) Natural Products (Secondary Metabolism). In: Buchanan RB, Gruissem W, Jones RL (eds) Biochemistry and Molecular Biology of Plants, American Society of Plant Biologists, Rockville, MD, USA, 1250-1318 
Crowell DN (2000) Functional implications of protein isoprenylation in plants. Prog Lipid Res 39: 393-408

Cunillera N, Arro M, Fores O, Manzano D, Ferrer A (2000) Characterization of dehydrodolichol diphosphate synthase of Arabidopsis thaliana, a key enzyme in dolichol biosynthesis. FEBS Lett 477: 170-174

Cunningham FX Jr, Gantt E (2000) Identification of multi-gene families encoding isopentenyl diphosphate isomerase in plants by heterologous complementation in Escherichia coli. Plant Cell Physiol 41: 119-123

Czechowski T, Bari RP, Stitt M, Scheible WR, Udvardi MK (2004) Real-time RT-PCR profiling of over 1400 Arabidopsis transcription factors: unprecedented sensitivity reveals novel root- and shoot-specific genes. Plant J 38: 366-379

da Silva FG, landolino A, Al-Kayal F, Bohlmann MC, Cushman MA, Lim H, Ergul A, Figueroa R, Kabuloglu EK, Osborne C, et al (2005) Characterizing the grape transcriptome. Analysis of expressed sequence tags from multiple Vitis species and development of a compendium of gene expression during berry development. Plant Physiol 139: 574-597

Dai M, Zhao Y, Ma Q, Hu Y, Hedden P, Zhang Q, Zhou DX (2007) The rice YABBY1 gene is involved in the feedback regulation of gibberellin metabolism. Plant Physiol 144: 121-133

Davies FS, Albrigo LG (1994) Cítricos. Ed Acribia, Zaragoza, España.

DeRidder BP, Goldsbrough PB (2006) Organ-specific expression of glutathione S-transferases and efficacy of herbicide safeners in Arabidopsis. Plant Physiol 140: $167-175$

Dijkstra P, Ter Reegen H, Kuiper PJC (1990) Relation between relative growth rate, endogenous gibberellins and the response to applied gibberellic acid for Plantago major. Physiol Plant 79: 629-634

Dong Q, Kroiss L, Oakley FD, Wang BB, Brendel V (2005) Comparative EST analyses in plant systems. Methods Enzymol 395: 400-418

Doostdar H, Shapiro JP, Niedz R, Burke MD, McCollum TG, McDonald RE, Mayer RT (1995) A cytochrome P450 mediated naringenin 3'-hydroxylase from sweet orange cell cultures. Plant Cell Physiol 36: 69-77

Dopazo J, Al-Shahrour F (2007) Functional annotation of microarray experiments. In: Falciani F (ed) Microarray Technology Through Applications. Taylor \& Francis Group, New York, USA, 155-171

Ducreux LJ, Morris WL, Hedley PE, Shepherd T, Davies HV, Millam S, Taylor MA (2005) Metabolic engineering of high carotenoid potato tubers containing enhanced levels of beta-carotene and lutein. J Exp Bot 56: 81-89 
Eddy SR (1998) Profile hidden Markov models. Bioinformatics 14: 755-763

Emanuelsson O, Brunak S, von Heijne G, Nielsen H (2007) Locating proteins in the cell using TargetP, SignalP and related tools. Nat Protoc 2: 953-971

Emanuelsson O, Nielsen H, Brunak S, von Heijne G (2000) Predicting subcellular localization of proteins based on their $\mathrm{N}$-terminal amino acid sequence. $\mathrm{J}$ Mol Biol 300: 1005-1016

Emanuelsson O, Nielsen H, von Heijne G (1999) ChloroP, a neural network-based method for predicting chloroplast transit peptides and their cleavage sites. Protein Sci 8: 978-984

Eriksson ME, Israelsson M, Olsson O, Moritz T (2000) Increased gibberellin biosynthesis in transgenic trees promotes growth, biomass production and xylem fiber length. Nat Biotechnol 18: 784-788

Eulgem T, Rushton PJ, Robatzek S, Somssich IE (2000) The WRKY superfamily of plant transcription factors. Trends Plant Sci 5: 199-206

Ewing RM, Ben Kahla A, Poirot O, Lopez F, Audic S, Claverie JM (1999) Largescale statistical analyses of rice ESTs reveal correlated patterns of gene expression. Genome Res 9: 950-959

Ewing B, Hillier L, WendI MC, Green P (1998) Base-calling of automated sequencer traces using phred. I. Accuracy assessment. Genome Res 8: 175-185

Fagoaga C, Tadeo FR, Iglesias DJ, Huerta L, Lliso I, Vidal AM, Talón M, Navarro L, García-Martínez JL, Peña L (2007) Engineering of gibberellin levels in citrus by sense and antisense overexpression of a GA 20-oxidase gene modifies plant architecture. J Exp Bot 58: 1407-1420

Fei Z, Tang X, Alba RM, White JA, Ronning CM, Martin GB, Tanksley SD, Giovannoni JJ (2004) Comprehensive EST analysis of tomato and comparative genomics of fruit ripening. Plant J 40: 47-59

Fernandes J, Brendel V, Gai X, Lal S, Chandler VL, Elumalai RP, Galbraith DW, Pierson EA, Walbot V (2002) Comparison of RNA expression profiles based on maize expressed sequence tag frequency analysis and micro-array hybridization. Plant Physiol 128: 896-910

Ferreira MA, Engler JD, Miguens FC, VanMontagu M, Engler G, deOliveira DE (1997) Oleosin gene expression in Arabidopsis thaliana tapetum coincides with accumulation of lipids in plastids and cytoplasmic bodies. Plant Physiol Biochem 35: 729-739 
Fizames C, Muños S, Cazettes C, Nacry P, Boucherez J, Gaymard F, Piquemal D, Delorme V, Commes T, Doumas P, et al (2004) The Arabidopsis root transcriptome by serial analysis of gene expression. Gene identification using the genome sequence. Plant Physiol 134: 67-80

Fleet CM, Sun TP (2005) A DELLAcate balance: the role of gibberellin in plant morphogenesis. Curr Op Plant Biol 8: 77-85

Foreman J, Demidchik V, Bothwell JH, Mylona P, Miedema H, Torres MA, Linstead P, Costa S, Brownlee C, Jones JD, et al (2003) Reactive oxygen species produced by NADPH oxidase regulate plant cell growth. Nature 422: 442-446

Forment J, Gadea J, Huerta L, Abizanda L, Agustí J, Alamar S, Alós E, Andrés F, Arribas R, Beltrán JP, Berbel A, Blázquez MA, Brumós J, Cañas LA, Cercós M, Colmenero-Flores JM, Conesa A, Estables B, Gandía M, GarcíaMartínez JL, Gimeno J, Gisbert A, Gómez G, González-Candelas L, Granell A, Guerra J, Lafuente MT, Madueño F, Marcos JF, Marqués MC, Martínez F, Martínez-Godoy MA, Miralles S, Moreno P, Navarro L, Pallás V, PérezAmador MA, Pérez-Valle J, Pons C, Rodrigo I, Rodríguez PL, Royo C, Serrano R, Soler G, Tadeo F, Talón M, Terol J, Trenor M, Vaello L, Vicente O, Vidal C, Zacarías L, Conejero V (2005) Development of a citrus genomewide EST collection and cDNA microarray as resources for genomic studies. Plant Mol Biol 57: 375-391

Forment J, Gilabert F, Robles A, Conejero V, Nuez F, Blanca JM (2008) EST2uni: an open, parallel tool for automated EST analysis and database creation, with a data mining web interface and microarray expression data integration. BMC Bioinformatics 9: 5

Fraser PD, Enfissi EM, Halket JM, Truesdale MR, Yu D, Gerrish C, Bramley PM (2007) Manipulation of phytoene levels in tomato fruit: effects on isoprenoids, plastids, and intermediary metabolism. Plant Cell 19: 3194-3211

Frydman A, Weisshaus O, Bar-Peled M, Huhman DV, Sumner LW, Marin FR, Lewinsohn E, Fluhr R, Gressel J, Eyal Y (2004) Citrus fruit bitter flavors: isolation and functional characterization of the gene $\mathrm{Cm} 1,2 \mathrm{RhaT}$ encoding a 1,2-rhamnosyltransferase, a key enzyme in the biosynthesis of the bitter flavonoids of citrus. Plant J 40: 88-100

Fujii H, Shimada T, Endo T, Shimizu T, Omura M (2006) 29,228 Citrus ESTscollection and analysis toward the functional genomics phase. In: Plant \& Animal Genomes XIV Conference. Town \& Country Convention Center. San Diego, CA. USA 
Fujioka S, Li J, Choi YH, Seto H, Takatsuto S, Noguchi T, Watanebe T, Kuriyama H, Yokota T, Chory J, Sakurai A (1997) The Arabidopsis deetiolated2 mutant is blocked early in brassinosteroid biosynthesis. Plant Cell 9: 1951-1962

Fujioka S, Yokota K (2003) Biosynthesis and metabolism of brassinosteroids. Annu Rev Plant Biol 54: 137-164

Galbraith DW, Birnbaum K (2006) Global studies of cell type-specific gene expression in plants. Annu Rev Plant Biol 57: 451-475

Gandía M, Conesa A, Ancillo G, Gadea J, Forment J, Pallás V, Flores R, DuranVila N, Moreno P, Guerri J (2007) Transcriptional response of Citrus aurantifolia to infection by Citrus tristeza virus. Virology 367: 298-306

Geisler M, Blakeslee JJ, Bouchard R, Lee OR, Vincenzetti V, Bandyopadhyay A, Titapiwatanakun B, Peer WA, Bailly A, Richards EL, et al (2005) Cellular efflux of auxin catalyzed by the Arabidopsis MDR/PGP transporter AtPGP1. Plant J 44: 179-194

Gmitter FG, Hu X (1990) The possible role of Yunnan, China, in the origin of comtemporany Citrus species (Rutaceae). Econ Bot 44: 267-277

Goff SA, Ricke D, Lan TH, Presting G, Wang R, Dunn M, Glazebrook J, Sessions A, Oeller P, Varma $\mathbf{H}$, et al (2002) A draft sequence of the rice genome (Oryza sativa L. ssp. japonica). Science 296: 92-100

González-Ibeas D, Blanca J, Roig C, González-To M, Picó B, Truniger V, Gómez P, Deleu W, Caño-Delgado A, Arús P, et al (2007) MELOGEN: an EST database for melon functional genomics. BMC Genomics 8: 306

Goto A, Yamane H, Takahashi N, Hirose K (1989) Identification of nine gibberellins from young fruit of Satsuma mandarin (Citrus unshiu Marc.) Agric Biol Chem 53: 2817-2818

Gupta PK, Rustgi S (2004) Molecular markers from the transcribed/expressed region of the genome in higher plants. Funct Integr Genomics 4: 139-162

Haas BJ, Delcher AL, Mount SM, Wortman JR, Smith RK Jr, Hannick LI, Maiti R, Ronning CM, Rusch DB, Town CD, et al (2003) Improving the Arabidopsis genome annotation using maximal transcript alignment assemblies. Nucleic Acids Res 31: 5654-5666

Hayat S, Ahmad A, Mobin M, Fariduddin Q, Azam ZM (2001) Carbonic anhydrase, photosynthesis, and seed yield in mustard plants treated with phytohormones. Photosynthetica 39: 111-114

Hedden P (2003) The genes of the Green Revolution. Trends Genet 19: 5-9

Hedden P, Kamiya Y (1997) Gibberellin biosynthesis: enzymes, genes and their regulation. Annu Rev Plant Physiol Plant Mol Biol 48: 431-460 
Hedden P, Phillips AL (2000a) Manipulation of hormone biosynthetic genes in transgenic plants. Curr Opin Biotechnol 11: 130-137

Hedden P, Phillips AL (2000b) Gibberellin metabolism: new insights revealed by the genes. Trends Plant Sci 5: 523-530

Heim MA, Jakoby M, Werber M, Martin C, Weisshaar B, Bailey PC (2003) The basic helix-loop-helix transcription factor family in plants: a genome-wide study of protein structure and functional diversity. Mol Biol Evol 20: 735-747

Herrero R, Asins MJ, Carbonell EA, Navarro L (1996) Genetic diversity in the orange subfamily Aurantioideae. I. Intraspecies and intragenus genetic variability. Theor Appl Gen 92: 599-609

Hirooka K, Bamba T, Fukusaki E, Kobayashi A (2003) Cloning and kinetic characterization of Arabidopsis thaliana solanesyl diphosphate synthase. Biochem J 370: 679-686

Hong Z, Ueguchi-Tanaka M, Shimizu-Sato S, Inukai Y, Fujioka S, Shimada Y, Takatsuto S, Agetsuma M, Yoshida S, Watanabe Y, et al (2002) Loss-offunction of a rice brassinosteroid biosynthetic enzyme, C-6 oxidase, prevents the organized arrangement and polar elongation of cells in the leaves and stem. Plant J 32: 495-508

Hu W, Ma H (2006) Characterization of a novel putative zinc finger gene MIF1: involvement in multiple hormonal regulation of Arabidopsis development. Plant J 45: 399-422

Huang X, Madan A (1999) CAP3: A DNA sequence assembly program. Genome Res 9: $868-877$

Huang S, Raman AS, Ream JE, Fujiwara H, Cerny RE, Brown SM (1998) Overexpression of 20-oxidase confers a gibberellin-overproduction phenotype in Arabidopsis. Plant Physiol 118: 773-781

Imoto K, Yokoyama R, Nishitani K (2005) Comprehensive approach to genes involved in cell wall modifications in Arabidopsis thaliana. Plant Mol Biol 58: 177-192

International Rice Genome Sequencing Project (2005) The map-based sequence of the rice genome. Nature 436: 793-800

Iseli C, Jongeneel CV, Bucher P (1999) ESTScan: a program for detecting, evaluating, and reconstructing potential coding regions in EST sequences. Proc Int Conf Intell Syst Mol Biol: 138-148

Israelsson M, Eriksson ME, Hertzberg M, Aspeborg H, Nilsson, Moriz T (2003) Changes in the wood-forming tissue of transgenic hybrid aspen with increased secondary growth. Plant Mol Biol 52: 893-903 
Israelsson M, Mellerowicz E, Chono M, Gullberg J, Moritz T (2004) Cloning and overproduction of gibberellin 3-oxidase in hybrid aspen trees. Effects on gibberellin homeostasis and development. Plant Physiol 135: 221-230

Jacobsen JV, Beach LR (1985) Control of transcription of $\alpha$-amylase and rRNA genes in barley aleurone protoplasts by gibberellin and abscisic acid. Nature 316: 275277

Jaillon O, Aury JM, Noel B, Policriti A, Clepet C, Casagrande A, Choisne N, Aubourg S, Vitulo N, Jubin C, et al (2007) The grapevine genome sequence suggests ancestral hexaploidization in major angiosperm phyla. Nature 449: 463-467

Jan A, Yang G, Nakamura H, Ichikawa H, Kitano H, Matsuoka M, Matsumoto H, Komatsu S (2004) Characterization of a xyloglucan endotransglucosylase gene that is up-regulated by gibberellin in rice. Plant Physiol 136: 3670-3681

Javot H, Lauvergeat V, Santoni V, Martin-Laurent F, Güçlü J, Vinh J, Heyes J, Franck KI, Schäffner AR, Bouchez D, Maurel C (2003) Role of a single aquaporin isoform in root water uptake. Plant Cell 15: 509-522

Kamiya Y, García-Martínez JL (1999) Regulation of gibberellin biosynthesis by light. Curr Opin Plant Biol 2: 398-403

Kanehisa M, Goto S, Kawashima S, Okuno Y, Hattori M (2004) The KEGG resource for deciphering the genome. Nucleic Acids Res 32: D277-D280

Kato M, Ikoma Y, Matsumoto H, Sugiura M, Hyodo H, Yano M (2004) Accumulation of carotenoids and expression of carotenoid biosynthetic genes during maturation in citrus fruit. Plant Physiol 134: 824-837

Kavi Kishor PB, Hong Z, Miao GH, Hu CAA, Verma DPS (1995) Over-expression of delta-pyrroline-5-carboxylate synthetase increases proline production and confers osmotolerance in transgenic plants. Plant Physiol 108: 1387-1394

Kawaii S, Tomono Y, Katase E, Ogawa K, Yano M (1999) Quantitation of flavonoid constituents in citrus fruits. J Agric Food Chem 47: 3565-3571

Kawaii S, Tomono Y, Katase E, Ogawa K, Yano M, Koizumi M, Ito C, Furukawa H (2000) Quantitative study of flavonoids in leaves of citrus plants. J Agric Food Chem 48: 3865-3871

Kim JK, Jang IC, Wu R, Zuo WN, Boston RS, Lee YH, Ahn IP, Nahm BH (2003) Coexpression of a modified maize ribosome-inactivating protein and a rice basic chitinase gene in transgenic rice plants confers enhanced resistance to sheath blight. Transgenic Res 12: 475-484 
Kita M, Hirata Y, Moriguchi T, Endo-Inagaki T, Matsumoto R, Hasegawa S, Suhayda CG, Omura M (2000) Molecular cloning and characterization of a novel gene encoding limonoid UDP-glucosyltransferase in Citrus. FEBBS Lett 469: $173-178$

Klimmek F, Sjödin A, Noutsos C, Leister D, Jansson S (2006) Abundantly and rarely expressed Lhc protein genes exhibit distinct regulation patterns in plants. Plant Physiol 140: 793-804

Ko JH, Yang SH, Han KH (2006) Upregulation of an Arabidopsis RING-H2 gene, $X E R I C O$, confers drought tolerance through increased abscisic acid biosynthesis. Plant J 47: 343-355

Komatsu S, Masuda T, Hirano H (1996) Rice gibberellin-binding phosphoprotein structurally related to ribulose-1,5-bisphosphate carboxylase/oxygenase activase. FEBBS Lett 384: 167-171

Koornneef M, van der Veen JH (1980) Induction and analysis of gibberellin-sensitive mutants in Arabidopsis thaliana (L.) Heynh. Theor Appl Gen 58: 257-263

Konishi H, Yamane H, Maeshima M, Komatsu S (2004) Characterization of fructosebisphosphate aldolase regulated by gibberellin in roots of rice seedling. Plant Mol Biol 56: 839-848

Krieger CJ, Zhang P, Mueller LA, Wang A, Paley S, Arnaud M, Pick J, Rhee SY, Karp PD (2004) MetaCyc: a multiorganism database of metabolic pathways and enzymes. Nucleic Acids Res 32: D438-D442

Kwak KJ, Kim JY, Kim YO, Kang H (2007) Characterization of transgenic Arabidopsis plants overexpressing high mobility group B proteins under high salinity, drought or cold stress. Plant Cell Physiol 48: 221-231

Lange BM, Ghassemian M (2003) Genome organization in Arabidopsis thaliana: a survey for genes involved in isoprenoid and chlorophyll metabolism. Plant Mol Biol 51: 925-948

Lee ML, Kuo FC, Whitmore GA, Sklar J (2000) Importance of replication in microarray gene expression studies: statistical methods and evidence from repetitive cDNA hybridizations. Proc Natl Acad Sci USA 97: 9834-9839

Leung YF, Cavalieri D (2003) Fundamentals of cDNA microarray data analysis. Trends Genet 19: 649-659

Li J, Nagpal P, Vitart V, McMorris TC, Chory J (1996) A role for brassinosteroids in light-dependent development of Arabidopsis. Science 272: 398-401

Lian X, Wang S, Zhang J, Feng Q, Zhang L, Fan D, Li X, Yuan D, Han B, Zhang Q (2006) Expression profiles of 10,422 genes at early stage of low nitrogen stress in rice assayed using a cDNA microarray. Plant Mol Biol 60:617-630 
López CG, Banowetz G, Peterson CJ, Kronstad WE (2001) Differential accumulation of a 24-kd dehydrin protein in wheat seedlings correlates with drought stress tolerance at grain filling. Hereditas 135: 175-181

Lota M, de Rocca Serra D, Tomi F, Casanova J (2001) Chemical variability of peel and leaf essential oils of 15 species of mandarins. Biochem Syst Ecol 29: 77104

Lücker J, Bouwmeester HJ, Aharoni A (2007) Metabolic Engineering of Terpenoid Biosynthesis in Plants. In: Verpoorte R, Alfermann AW, Johnson TS (ed) Applications of Plant Metabolic Engineering. Springer Pub, The Netherlands, 219-236

Lücker J, Bowen P, Bohlmann J (2004) Vitis vinifera terpenoid cyclases: functional identification of two sesquiterpene synthase cDNAs encoding (+)-valencene synthase and (-)-germacrene $D$ synthase and expression of mono- and sesquiterpene synthases in grapevine flowers and berries. Phytochemistry 65: 2649-2659

Lücker J, El Tamer MK, Schwab W, Verstappen FW, van der Plas LH, Bouwmeester HJ, Verhoeven HA (2002) Monoterpene biosynthesis in lemon (Citrus limon). cDNA isolation and functional analysis of four monoterpene synthases. Eur J Biochem 269: 3160-3171

Ma X, Panjikar S, Koepke J, Loris E, Stöckigt J (2006) The structure of Rauvolfia serpentina strictosidine synthase is a novel six-bladed beta-propeller fold in plant proteins. Plant Cell 18: 907-920

Ma L, Sun N, Liu X, Jiao Y, Zhao H, Deng XW (2005) Organ-specific expression of Arabidopsis genome during development. Plant Physiol 138: 80-91

Machado MA, Amaral AM, Freitas-Astua J, Berger IJ, Boscariol-Camargo R, Carlos EF, Filho HC, Locali EC, Lucheta AR, Stach-Machado DR, et al (2007) Analysis of Citrus transcriptome: CitEST in Brazil. In Plant \& Animal Genomes XV Conference. Town \& Country Convention Center. San Diego, CA. USA

Machado MA, Souza AA, Targon ML, Takita MA, Freitas-Astua J, Filho HC, Amaral AM, Palmieri DA, Boscariol-Camargo R, Cristofani M, et al (2006) Current situation of Citrus genome project in Brazil (CitEST). In Plant \& Animal Genomes XIV Conference. Town \& Country Convention Center. San Diego, CA. USA 
Magome H, Yamaguchi S, Hanada A, Kamiya Y, Oda K (2004) dwarf and delayedflowering 1, a novel Arabidopsis mutant deficient in gibberellin biosynthesis because of overexpression of a putative AP2 transcription factor. Plant $\mathrm{J} \mathbf{3 7}$ : $720-729$

Malmberg R, Messing J, Sussex I (1985) Molecular biology of plants. A laboratory course manual. New York: Cold Spring Harbor Laboratory Press, 41

Mandaokar A, Thines B, Shin B, Lange BM, Choi G, Koo YJ, Yoo YJ, Choi YD, Choi G, Browse J (2006) Transcriptional regulators of stamen development in Arabidopsis identified by transcriptional profiling. Plant J 46: 984-1008

Manthey JA, Grohmann K, Guthrie N (2001) Biological properties of citrus flavonoids pertaining to cancer and inflammation. Curr Med Chem 8: 135-153

Martens S, Forkmann G (1999) Cloning and expression of flavone synthase II from Gerbera hybrids. Plant J 20: 611-618

Martin DM, BohImann J (2004) Identification of Vitis vinifera (-)-alpha-terpineol synthase by in silico screening of full-length cDNA ESTs and functional characterization of recombinant terpene synthase. Phytochemistry 65: 12231229

Martin VJ, Pitera DJ, Withers ST, Newman JD, Keasling JD (2003) Engineering a mevalonate pathway in Escherichia coli for production of terpenoids. Nat Biotechnol 21:796-802

Maruyama T, Ito M, Honda G (2001) Molecular cloning, functional expression and characterization of $(E)$-beta farnesene synthase from Citrus junos. Biol Pharm Bull 24: 1171-1175

McIntosh CA, Latchinian L, Mansell RL (1990) Biosynthesis of naringin in Citrus paradisi: UDP-glucosyl-transferase activity in grapefruit seedlings. Phytochemistry 29: 1533-1538

Meyerowitz EM (2002) Plants compared to animals: the broadest comparative study of development. Science 295: 1482-1485

Meyers BC, Galbraith DW, Nelson T, Agrawal V (2004) Methods for transcriptional profiling in plants. Be fruitful and replicate. Plant Physiol 135: 637-652

Middleton E Jr, Kandaswami C, Theoharides TC (2000) The effects of plant flavonoids on mammalian cells: implications for inflammation, heart disease, and cancer. Pharmacol Rev 52: 673-751

Monna L, Kitazawa N, Yoshino R, Suzuki J, Masuda H, Maehara Y, Tanji M, Sato M, Nasu S, Minobe Y (2002) Positional cloning of rice semidwarfing gene, sd-1: rice "green revolution gene" encodes a mutant enzyme involved in gibberellin synthesis. DNA Res 28: 11-17 
Moore GA (2001) Oranges and lemons: clues to the taxonomy of Citrus from molecular markers. Trends Genet 17: 536-540

Moriguchi T, Kita M, Hasegawa S, Omura M (2003) Molecular approach to citrus flavonoid and limonoid biosynthesis. Food, Agriculture and Environment 1: 2225

Moriguchi T, Kita M, Ogawa K, Tomono Y, Endo T, Omura M (2002) Flavonol synthase gene expresión during citrus fruit development. Physiol Plant 114: 251-258

Moriguchi T, Kita M, Tomono Y, Endo-Inagaki T, Omura M (1999) One type of chalcone synthase gene expressed during embryogenesis regulates the flavonoid accumulation in citrus cell cultures. Plant Cell Physiol 40: 651-655

Moriguchi T, Kita M, Tomono Y, Endo-Inagaki T, Omura M (2001) Gene expression in flavonoid biosynthesis: correlation with flavonoid accumulation in developing citrus fruit. Physiol Plant 111: 66-74

Mozer TJ (1980) Control of Protein Synthesis in Barley Aleurone Layers by the Plant Hormones Gibberellic Acid and Abscisic Acid. Cell 20: 479-485

Mueller LA, Zhang P, Rhee SY (2003) AraCyc: a biochemical pathway database for Arabidopsis. Plant Physiol 132: 453-460

Nagel OW, Lambers H (2002) Changes in the acquisition and partitioning of carbon and nitrogen in the gibberellin-deficient mutants $A 70$ and W335 of tomato (Solanum lycopersicum L.). Plant Cell Environ 25: 883-891

Nakai K, Horton P (1999) PSORT: a program for detecting sorting signals in proteins and predicting their subcellular localization. Trends Biochem Sci 24: 34-36

Nambara E, Marion-Poll A (2005) Abscisic Acid Biosynthesis and Catabolism. Annu Rev Plant Biol 56: 165-185

Nawy T, Lee JY, Colinas J, Wang JY, Thongrod SC, Malamy JE, Birnbaum K, Benfey PN (2005) Transcriptional profile of the Arabidopsis root quiescent center. Plant Cell 17: 1908-1925

Neuhaus JL (1999) Plant chitinase (PR-3, PR-4, PR-8, PR-11). In: Datta S, Muthukrishnan S (eds) Pathogenesis-related Proteins in Plants. Boca Raton, CRC Press, 77-105

Newcomb RD, Crowhurst RN, Gleave AP, Rikkerink EH, Allan AC, Beuning LL, Bowen JH, Gera E, Jamieson KR, Janssen BJ, et al (2006) Analyses of expressed sequence tags from apple. Plant Physiol 141: 147-166 
Nishikawa F, Endo T, Shimada T, Fujii H, Shimizu T, Omura M, Ikoma Y (2007) Increased CiFT abundance in the stem correlates with floral induction by low temperature in Satsuma mandarin (Citrus unshiu Marc.). J Exp Bot 58: 39153927

Noctor G, Foyer CH (1998) Ascorbate and glutathione: keeping active oxygen under control. Annu Rev Plant Physiol Plant Mol Biol 49: 249-279

Nomura T, Sato T, Bishop GJ, Kamiya Y, Takatsuto S, Yokota T (2001) Accumulation of 6-deoxocathasterone and 6-deoxocastasterone in Arabidopsis, pea and tomato is suggestive of common rate-limiting steps in brassinosteroid biosynthesis. Phytochemistry 57: 171-178

Norusis MJ (1993) Documentation SPSS for Windows, SPSS, Inc., Chicago

Ogawa M, Hanada A, Yamauchi Y, Kuwahara A, Kamiya Y, Yamaguchi S (2003) Gibberellin biosynthesis and response during Arabidopsis seed germination. Plant Cell 15: 1591-1604

Ogawa M, Kusano T, Katsumi M, Sano H (2000) Rice gibberellin-insensitive gene homolog, OsGAl, encodes a nuclear-localized protein capable of gene activation at transcriptional level. Gene 245: 21-29

Ogihara Y, Mochida K, Nemoto Y, Murai K, Yamazaki Y, Shin-I T, Kohara Y (2003) Correlated clustering and virtual display of gene expression patterns in the wheat life cycle by large-scale statistical analyses of expressed sequence tags. Plant J 33: 1001-1011

Ohlrogge J, Benning C (2000) Unraveling plant metabolism by EST analysis. Curr Opin Plant Biol 3: 224-228

Ohnishi T, Szatmari AM, Watanabe B, Fujita S, Bancos S, Koncz C, Lafos M, Shibata K, Yokota T, Sakata K, et al (2006) C-23 hydroxylation by Arabidopsis CYP90C1 and CYP90D1 reveals a novel shortcut in brassinosteroid biosynthesis. Plant Cell 18: 3275-3288

Olszewski N, Sun TP, Gubler F (2002) Gibberellin signalling, biosynthesis, catabolism, and response pathways. Plant Cell 14: S61-S80

Park S, Sugimoto N, Larson MD, Beaudry R, van Nocker S (2006) Identification of genes with potential roles in apple fruit development and biochemistry through large-scale statistical analysis of expressed sequence tags. Plant Physiol 141: 811-824

Pertea G, Huang X, Liang F, Antonescu V, Sultana R, Karamycheva S, Lee Y, White J, Cheung F, Parvizi B, Tsai J, Quackenbush J (2003) TIGR Gene Indices clustering tools (TGICL): a software system for fast clustering of large EST datasets. Bioinformatics 19: 651-652 
Phillips AL, Huttly AK (1994) Cloning of two gibberellin-regulated cDNAs from Arabidopsis thaliana by subtractive hybridization: expression of the tonoplast water channel, $\mathrm{Y}$-TIP, is increased by $\mathrm{GA}_{3}$. Plant Mol Biol 24: 603-615

Pierleoni A, Martelli PL, Fariselli P, Casadio R (2006) BaCelLo: a balanced subcellular localization predictor. Bioinformatics 22: 408-416

Poling SM, Maier VP (1988) Identification of endogenous gibberellins in navel orange shoots. Plant Physiol 88: 639-642

Potter I, Fry SC (1993) Xyloglucan endotransglycosylase activity in pea internodes. Effects of applied gibberellic acid. Plant Physiol 103: 235-24

Rabbani MA, Maruyama K, Abe H, Khan MA, Katsura K, Ito Y, Yoshiwara K, Seki M, Shinozaki K, Yamaguchi-Shinozaki K (2003) Monitoring expression profiles of rice genes under cold, drought, and high-salinity stresses and abscisic acid application using cDNA microarray and RNA gel-blot analyses. Plant Physiol 133: 1755-1767

Redman JC, Haas BJ, Tanimoto G, Town CD (2004) Development and evaluation of an Arabidopsis whole genome Affymetrix probe array. Plant J 38: 545-561

Reid J, Howell SH (1995) Hormone mutants and plant development. In: Davies P (ed) Plant Hormones: Physiology, Biochemistry and Molecular Biology, $2^{\mathrm{d}}$ ed. Kluwer Acad Pub, Dordrecht, The Netherlands, 448-485

Reiling KK, Yoshikuni Y, Martin VJ, Newman J, Bohlmann J, Keasling JD (2004) Mono and diterpene production in Escherichia coli. Biotechnol Bioeng 87: 200212

Rensink WA, Buell CR (2005) Microarray expression profiling resources for plant genomics. Trends Plant Sci 10: 603-609

Rhee SY, Beavis W, Berardini TZ, Chen G, Dixon D, Doyle A, García-Hernández M, Huala E, Lander G, Montoya M, et al (2003) The Arabidopsis Information Resource (TAIR): a model organism database providing a centralized, curated gateway to Arabidopsis biology, research materials and community. Nucleic Acids Res 31: 224-228

Riechmann JL, Ratcliffe OJ (2000) A genomic perspective on plant transcription factors. Curr Op Plant Biol 3: 423-434

Rodríguez-Concepción M, Boronat A (2002) Elucidation of the methylerythritol phosphate pathway for isoprenoid biosynthesis in bacteria and plastids. A metabolic milestone achieved through genomics. Plant Physiol 130: 1079-1089

Rodrigo MJ, Zacarías L (2006) Horticultural and quality aspects of Citrus fruits. In: Hiu YH (ed) Handbook of Fruits Processing and Technology. Blackwell Publishing, lowa, USA, 293-308 
Romualdi C, Bortoluzzi S, D'Alessi F, Danieli GA (2003) IDEG6: a web tool for detection of differentially expressed genes in multiple tag sampling experiments. Physiol Genomics 12: 159-162

Ronning CM, Stegalkina SS, Ascenzi RA, Bougri O, Hart AL, Utterbach TR, Vanaken SE, Riedmuller SB, White JA, Cho J, et al (2003) Comparative analyses of potato expressed sequence tag libraries. Plant Physiol 131: 419429

Roose ML, Niedz RP, Gmitter FG, Close TJ, Dandekar AM, Cheng JF, Rokhsar DS (2007) Analysis of a 1.2x whole genome sequence of Citrus sinensis. In Plant \& Animal Genomes XV Conference. Town \& Country Convention Center. San Diego, CA. USA

Ruan Y, Gilmore J, Conner T (1998) Towards Arabidopsis genome analysis: monitoring expression profiles of 1400 genes using cDNA microarrays. Plant $\mathrm{J}$ 15: $821-833$

Rudd S (2003) Expressed sequence tags: alternative or complement to whole genome sequence? Trends Plant Sci 8: 321-329

Rudd S, Schoof H, Mayer K (2005) PlantMarkers - a database of predicted molecular markers from plants. Nucleic Acids Res 33: D628-D632

Ruepp A, Zollner A, Maier D, Albermann K, Hani J, Mokrejs M, Tetko I, Guldener U, Mannhaupt G, Munsterkotter M, Mewes HW (2004) The FunCat, a functional annotation scheme for systematic classification of proteins from whole genomes. Nucleic Acids Res 32: 5539-5545

Sakamoto T, Matsuoka M (2004) Generating high-yielding varieties by genetic manipulation of plant architecture. Curr Opin Biotechnol 15: 144-147

Sambrook J, Frish EF, Maniatis T (1989) Molecular cloning: a laboratory manual. Cold Spring Harbor Laboratory Press, New York

Sasaki A, Ashikari M, Ueguchi-Tanaka M, Itoh H, Nishimura A, Swapan D, Ishiyama K, Saito T, Kobayashi M, Khush GS, Kitano H, Matsuoka M (2002) Green revolution: a mutant gibberellin-synthesis gene in rice. Nature 416: 701-702

Savage EM, Gadner FE (1965) The origin and history of Troyer and Carrizo citranges. The Citrus Industry 26: 5

Scheible WR, Pauly M (2004) Glycosyltransferases and cell wall biosynthesis: novel players and insights. Curr Opin Plant Biol 7: 285-295

Scheller HV, Lunde C, Haldrup A, Jensen PE (2005) Functional characterization of the photosynthetic apparatus in Arabidopsis thaliana. In: Leister D (ed) Plant Functional Genomics, Food Product Press, New York, USA, 393-429 
Schena M, Shalon D, Davis RW, Brown PO (1995) Quantitative monitoring of gene expression patterns with a complementary DNA microarray. Science 270: 467470

Schmid M, Davison TS, Henz SR, Pape UJ, Demar M, Vingron M, Schölkopf B, Weigel D, Lohmann JU (2005) A gene expression map of Arabidopsis thaliana development. Nat Genet 37: 501-506

Schwechheimer C (2008) Understanding gibberellic acid signaling-are we there yet? Curr Opin Plant Biol 11: 9-15

Seo HS, Song JT, Cheong JJ, Lee YH, Lee YW, Hwang I, Lee JS, Choi YD (2001) Jasmonic acid carboxyl methyltransferase: a key enzyme for jasmonateregulated plant responses. Proc Natl Acad Sci USA 98: 4788-4793

Serrano-Cartagena J, Candela H, Robles P, Ponce MR, Pérez-Pérez JM, Piqueras P, Micol JL (2000) Genetic analysis of incurvata mutants reveals three independent genetic operations at work in Arabidopsis leaf morphogenesis. Genetics 156: 1363-1377

Sharma A, Komatsu S (2002) Involvement of a $\mathrm{Ca}(2+)$-dependent protein kinase component downstream to the gibberellin-binding phosphoprotein, RuBisCO activase, in rice. Biochem Biophys Res Commun 290: 690-695

Sharon-Asa L, Shalit M, Frydman A, Bar E, Holland D, Or E, Lavi U, Lewinsohn E, Eyal Y (2003) Citrus fruit flavor and aroma biosynthesis: isolation, functional characterization, and developmental regulation of Cstps1, a key gene in the production of the sesquiterpene aroma compound valencene. Plant $\mathrm{J}$ 36: 664674

Shi H, Zhu JK (2002) SOS4, a pyridoxal kinase gene, is required for root hair development in Arabidopsis. Plant Physiol 129: 585-593

Shimada T, Endo T, Fujii H, Hara M, Ueda T, Kita M, Omura M (2004) Molecular cloning and functional characterization of four monoterpene synthase genes from Citrus unshiu Marc. Plant Sci 166: 49-58

Shimada Y, Fujioka S, Miyauchi N, Kushiro M, Takatsuto S, Nomura T, Yokota T, Kamiya Y, Bishop GJ, Yoshida S (2001) Brassinosteroid-6-oxidases from arabidopsis and tomato catalyze multiple C-6 oxidations in brassinosteroid biosynthesis. Plant Physiol 126: 770-779

Shin B, Choi G, Yi H, Yang S, Cho I, Kim J, Lee S, Paek NC, Kim JH, Song PS, Choi G (2002) AtMYB21, a gene encoding a flower-specific transcription factor, is regulated by COP1. Plant $\mathrm{J}$ 30: $23-32$ 
Sivamani E, Bahieldin1 A, Wraith JM, Al-Niemi T, Dyer WE, Ho TD, Qu R (2000) Improved biomass productivity and water use efficiency under water deficit conditions in transgenic wheat constitutively expressing the barley HVA1 gene. Plant Sci 155: 1-9

Smith RC, Matthews PR, Schünmnn PHD, Chandler PM (1996) The regulation of leaf elongation and xyloglucan endotransglycosylase by gibberellin in 'Himalaya' barley (Hordeum vulgare L.) J Exp Bot 47: 1395-1404

Sorin C, Negroni L, Balliau T, Corti H, Jacquemot MP, Davanture M, Sandberg G, Zivy M, Bellini C (2006) Proteomic analysis of different mutant genotypes of Arabidopsis led to the identification of 11 proteins correlating with adventitious root development. Plant Physiol 140: 349-364

Spencer MW, Casson SA, Lindsey K (2007) Transcriptional profiling of the Arabidopsis embryo. Plant Physiol 143: 924-940

Spiegel-Roy P, Goldschmidt EE (1996) Biology of citrus. Cambridge University Press. Cambridge, GB

Spielmeyer W, Ellis MH, Chandler PM (2002) Semidwarf (sd-1), "green revolution" rice, contains a defective gibberellin 20-oxidase gene. Proc Natl Acad Sci USA 99: 9043-9048

Sponsel V, Hedden V (2004) Gibberellin biosynthesis and inactivation. In: Davies P (ed) Plant Hormones: Biosynthesis, Signal Transduction, Actionj. 3d ed. Kluwer Acad Pub, Dordrecht, The Netherlands, 63-94

Starks CM, Back K, Chappell J, Noel JP (1997) Structural basis for cyclic terpene biosynthesis by tobacco 5-epi-aristolochene synthase. Science 277: 181518520

Steele CL, Crock J, Bohlmann J, Croteau R (1998) Sesquiterpene synthases from grand fir (Abies grandis). Comparison of constitutive and wound-induced activities, and cDNA isolation, characterization, and bacterial expression of delta-selinene synthase and gamma-humulene synthase. J Biol Chem 273: 2078-2089

Sterky F, Bhalerao RR, Unneberg P, Segerman B, Nilsson P, Brunner AM, Charbonnel-Campaa L, Lindvall JJ, Tandre K, Strauss SH, et al (2004) A Populus EST resource for plant functional genomics. Proc Natl Acad Sci USA 101: $13951-13956$

Sterky F, Regan S, Karlsson J, Hertzberg M, Rohde A, Holmberg A, Amini B, Bhalerao R, Larsson M, Villarroel R, et al (1998) Gene discovery in the woodforming tissues of poplar: analysis of 5,692 expressed sequence tags. Proc Natl Acad Sci USA 95: 13330-13335 
Street NR, Skogström O, Sjödin A, Tucker J, Rodríguez-Acosta M, Nilsson P, Jansson S, Taylor G (2006) The genetics and genomics of the drought response in Populus. Plant J 48: 321-341

Stupar RM, Bhaskar PB, Yandell BS, Rensink WA, Hart AL, Ouyang S, Veilleux RE, Busse JS, Erhardt RJ, Buell CR, Jiang J (2006) Phenotypic and transcriptomic changes associated with potato autopolyploidization. Genetics 176: $2055-2067$

Sun TP (2004) Gibberellin signal transduction in stem elongation and leaf growth. In: Davies P (ed) Plant Hormones: Biosynthesis, Signal Transduction, Actioni. 3d ed. Kluwer Acad Pub, Dordrecht, The Netherlands, 304-320

Sun TP, Gubler E (2004) Molecular mechanism of gibberellin signaling in plants. Annu Rev Plant Biol 55: 197-223

Sun TP, Kamiya Y (1996) The Arabidopsis GA1 locus encodes the cyclase entkaurene synthase A of gibberellin biosynthesis. Plant Cell 6: 1509-1518

Swain SM, Singh DP (2005) Tall tales from sly dwarves: novel functions of gibberellins in plant development. Trends Plant Sci 10: 123-129

Swingle WT, Reece PC (1967) The botany of Citrus and its relatives. In: Reuther W, Webber H, Batchelor L (eds) The Citrus Industry. University of California, USA

Syvertsen JP (1984) Light acclimation in Citrus leaves. II. Assimilation and light, water and nitrogen efficiency. J Amer Soc Hort Sci 109: 812-817

Szekeres M, Németh K, Koncz-Kálmán Z, Mathur J, Kauschmann A, Altmann T, Rédei GP, Nagy F, Schell J, Koncz C (1996) Brassinosteroids rescue the deficiency of CYP90, a cytochrome P450, controlling cell elongation and deetiolation in Arabidopsis. Cell 85: 171-182

Talón M, Hedden P, Primo-Millo E (1990) Gibberellins in Citrus sinensis: a comparison between seeded and seedless varieties. J Plant Growth Regul 9: 201-206

Talón M, Zacarías L, Primo-Millo E (1992) Gibberellins and parthenocarpic ability in developing ovaries of seedless mandarins. Plant Physiol 99: 1575-1581

Tanaka T (1977) Fundamental discussion of Citrus classification. Stud Citrol 14: 1-6

Terol J, Conesa A, Colmenero JM, Cercós M, Tadeo F, Agustí J, Alós E, Andrés F, Soler G, Brumós J, et al (2007) Analysis of 13000 unique Citrus clusters associated with fruit quality, production and salinity tolerance. BMC Genomics 8: 31

Terol J, Talón M (2008) Analysis of the repetitive content of the genome Citrus clementina based on BAC-end sequencing. In Plant \& Animal Genomes XVI Conference. Town \& Country Convention Center. San Diego, CA. USA 
Thomas SG, Phillips AL, Hedden P (1999) Molecular cloning and functional expression of gibberellin 2-oxidases, multifunctional enzymes involved in gibberellin deactivation. Proc Natl Acad Sci USA 96: 4698-4703

Turnbull CGN (1989) Identification and quantitative analysis of gibberellins in Citrus. J Plant Growth Regul 8: 273-282

Tusher VG, Tibshirani R, Chu G (2001) Significance analysis of microarrays applied to the ionizing radiation response. Proc Natl Acad Sci USA 98: 5116-5121

Tuskan GA, Difazio S, Jansson S, Bohlmann J, Grigoriev I, Hellsten U, Putnam N, Ralph S, Rombauts S, Salamov A, et al (2006) The genome of black cottonwood, Populus trichocarpa (Torr. \& Gray). Science 313: 1596-1604

Uozu S, Tanaka-Ueguchi M, Kitano H, Hattori K, Matsuoka M (2000) Characterization of XET-related genes of rice. Plant Physiol 122: 853-859

van der Knaap E, Jagoueix S, Kende H (1997) Expression of an ortholog of replication protein $\mathrm{A} 1$ (RPA1) is induced by gibberellin in deepwater rice. Proc Natl Acad Sci USA 94: 9979-9983

van Schie CC, Ament K, Schmidt A, Lange T, Haring MA, Schuurink RC (2007) Geranyl diphosphate synthase is required for biosynthesis of gibberellins. Plant J 52: $752-762$

Varshney RK, Graner A, Sorrells ME (2005) Genomics-assisted breeding for crop improvement. Trends Plant Sci 10: 621-630

Velasco R, Zharkikh A, Troggio M, Cartwright DA, Cestaro A, Pruss D, Pindo M, Fitzgerald LM, Vezzulli S, Reid J, et al (2007) A high quality draft consensus sequence of the genome of a heterozygous grapevine variety. PLoS ONE 2: e1326

Ververidis F, Trantas E, Douglas C, Vollmer G, Kretzschmar G, Panopoulos N (2007) Biotechnology of flavonoids and other phenylpropanoid-derived natural products. Part I: Chemical diversity, impacts on plant biology and human health. Biotechnol J 2: 1214-1234

Vidal AM, Ben-Cheikh W, Talón M, García-Martínez JL (2003) Regulation of gibberellin 20-oxidase gene expression and gibberellin content in citrus by temperature and citrus exocortis viroid. Planta 217: 442-448

Vidal AM, Gisbert C, Talón M, Primo-Millo E, López-Díaz I, García-Martínez JL (2001) The ectopic overexpression of a citrus gibberellin 20-oxidase enhances the non-13-hydroxylation pathway of gibberellin biosynthesis and induces an extremely elongated phenotype in tobacco. Physiol Plant 112: 251-260 
Vodkin LO, Khanna A, Shealy R, Clough SJ, Gonzalez DO, Philip R, Zabala G, Thibaud-Nissen F, Sidarous M, Strömvik MV, et al (2004) Microarrays for global expression constructed with a low redundancy set of 27,500 sequenced cDNAs representing an array of developmental stages and physiological conditions of the soybean plant. BMC Genomics 5: 73

Wang ZY, Kenigsbuch D, Sun L, Harel E, Ong MS, Tobin EM (1997) A Myb-related transcription factor is involved in the phytochrome regulation of an Arabidopsis Lhcb gene. Plant Cell 9: 491-507

Wellmann F, Lukacin R, Moriguchi T, Britsch L, Schiltz E, Matern U (2002) Functional expression and mutational analysis of flavonol synthase from Citrus unshiu. Eur J Biochem 269: 4134-4142

Wilson RN, Heckman JW, Somerville CR (1992) Gibberellin is required for flowering in Arabidopsis thaliana under short days. Plant Physiol 100: 403-408

Winkel-Shirley B (2001) Flavonoid biosynthesis. A colorful model for genetics, biochemistry, cell biology, and biotechnology. Plant Physiol 126: 485-493

Wortman JR, Haas BJ, Hannick LI, Smith RK Jr, Maiti R, Ronning CM, Chan AP, Yu C, Ayele M, Whitelaw CA, et al (2003) Annotation of the Arabidopsis genome. Plant Physiol 132: 461-468

Wu CH, Apweiler R, Bairoch A, Natale DA, Barker WC, Boeckmann B, Ferro S, Gasteiger E, Huang H, López R, et al (2006) The Universal Protein Resource (UniProt): an expanding universe of protein information. Nucleic Acids Res 1: 187-191.

Xu D, Duan X, Wang B, Hong B, Ho T, Wu R (1996) Expression of a Late Embryogenesis Abundant Protein Gene, HVA1, from Barley Confers Tolerance to Water Deficit and Salt Stress in Transgenic Rice. Plant Physiol 110: 249-257

Yamaguchi S, Kamiya Y (2000) Gibberellin biosynthesis: its regulation by endogenous and environmental signals. Plant Cell Physiol 41: 251-257

Yamaguchi-Shinozaki K, Koizumi M, Urao S, Shinozaki K (1992) Molecular cloning and characterization of 9 cDNAs for genes that are responsive to desiccation in Arabidopsis thaliana: Sequence analysis of one cDNA clone that encodes a putative transmembrane channel protein. Plant Cell Physiol 33: 217-224

Yang YH, Dudoit S, Luu P, Lin DM, Peng V, Ngai J, Speed TP (2002) Normalization for cDNA microarray data: a robust composite method addressing single and multiple slide systematic variation. Nucleic Acids Res. 30: e15 
Yang GX, Jan A, Shen SH, Yazaki J, Ishikawa M, Shimatani Z, Kishimoto N, Kikuchi S, Matsumoto H, Komatsu S (2004) Microaray analysis of brassinosteroids- and gibberellin-regulated gene expression in rice seedlings. Mol Gen Genomics 271: 468-478

Yang YH, Speed T (2002) Design issues for cDNA microarray experiments. Nat Rev Genet 3: $579-588$

Yanhui C, Xiaoyuan Y, Kun H, Meihua L, Jigang L, Zhaofeng G, Zhiqiang L, Yunfei Z, Xiaoxiao W, Xiaoming Q, et al (2006) The MYB transcription factor superfamily of Arabidopsis: expression analysis and phylogenetic comparison with the rice MYB family. Plant Mol Biol 60: 107-124

Yazaki J, Shimatani Z, Hashimoto A, Nagata Y, Fujii F, Kojima K, Suzuki K, Taya T, Tonouchi M, Nelson C, et al (2004) Transcriptional profiling of genes responsive to abscisic acid and gibberellin in rice: phenotyping and comparative analysis between rice and Arabidopsis. Physiol Genomics 17: 87-100

Yu J, Hu S, Wang J, Wong GK, Li S, Liu B, Deng Y, Dai L, Zhou Y, Zhang X, et al (2002) A draft sequence of the rice genome (Oryza sativa L. ssp. indica). Science 296: 79-92

Yuan L, Xu DQ (2001) Stimulation effect of gibberellic acid short-term treatment on leaf photosynthesis related to the increase in Rubisco content in broad bean and soybean. Photosynth Res 68: 39-47

Yue H, Eastman PS, Wang BB, Minor J, Doctolero MH, Nuttall RL, Stack R, Becker JW, Montgomery JR, Vainer M, Johnston R (2001) An evaluation of the performance of cDNA microarrays for detecting changes in global mRNA expression. Nucleic Acids Res 29: e41

Zentella R, Zhang ZL, Park M, Thomas SG, Endo A, Murase K, Fleet CM, Jikumaru Y, Nambara E, Kamiya Y, Sun TP (2007) Global analysis of DELLA direct targets in early gibberellin signaling in Arabidopsis. Plant Cell 19: 3037-3057

Zhang Z, Schwartz S, Wagner L, Miller W (2000) A greedy algorithm for aligning DNA sequences. J Comput Biol 7: 203-214

Zhang H, Sreenivasulu N, Weschke W, Stein N, Rudd S, Radchuk V, Potokina E, Scholz U, Schweizer P, Zierold U, et al (2004) Large-scale analysis of the barley transcriptome based on expressed sequence tags. Plant J 40: 276-290

Zhu B, Choi DW, Fenton R, Close TJ (2000) Expression of the barley dehydrin multigene family and the development of freezing tolerance. Mol Gen Genet 264: $145-153$ 


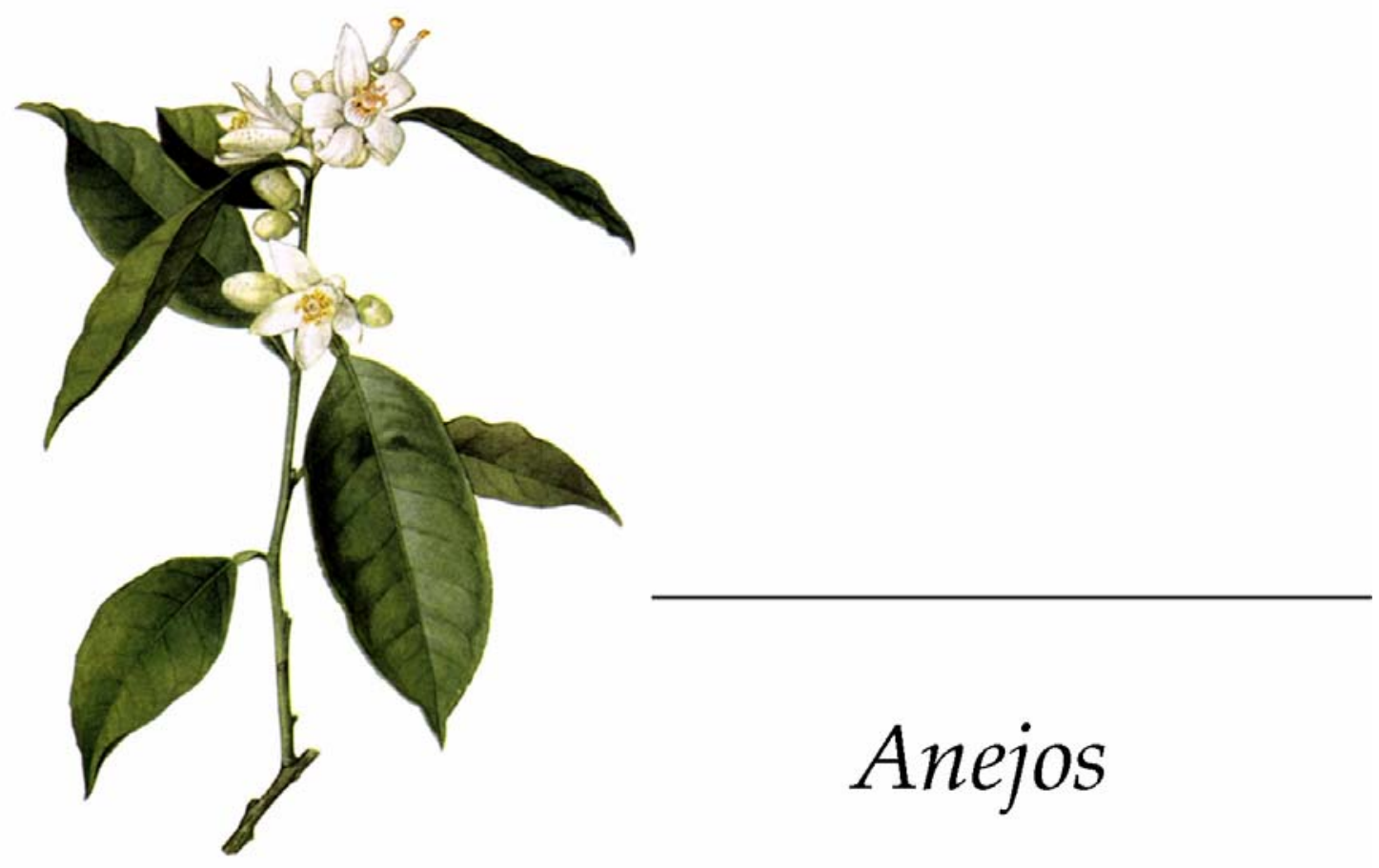





\begin{tabular}{|c|c|c|c|}
\hline $\begin{array}{c}\text { Unigen } \\
\text { de cítricos }\end{array}$ & $\begin{array}{c}\text { Código } \\
\text { AGI }\end{array}$ & Descripción & Valor $E$ \\
\hline aCL43Contig3 & At5g38410 & RuBisCO small subunit 3B (RBCS-3B) & $3 E-77$ \\
\hline aCL705Contig1 & At3g26740 & light responsive protein-related & $6 \mathrm{E}-30$ \\
\hline aCL428Contig1 & At4g24220 & expressed protein & $2 \mathrm{E}-85$ \\
\hline aCL63Contig4 & At4g35090 & catalase 2 & 0 \\
\hline aCL14Contig6 & At2g34430 & chlorophyll A-B binding protein / LHCII type I (LHB1B1) & $1 \mathrm{E}-132$ \\
\hline aCL7Contig10 & At3g15353 & metallothionein protein & $1 \mathrm{E}-17$ \\
\hline aCL48Contig2 & At2g39730 & RuBisCO activase (RA) & 0 \\
\hline aCL11Contig1 & At5g06740 & lectin protein kinase family protein & $8 \mathrm{E}-14$ \\
\hline aCL93Contig1 & At4g10340 & chlorophyll A-B binding protein CP26 (LHCB5) & $1 \mathrm{E}-130$ \\
\hline aCL871Contig1 & At3g01500 & carbonic anhydrase 1 (CA1) & $1 \mathrm{E}-115$ \\
\hline aCL241Contig1 & At3g45140 & lipoxygenase (LOX2) & 0 \\
\hline aCL23Contig1 & At1g47128 & cysteine proteinase $(\mathrm{RD} 21 \mathrm{~A})$ & 0 \\
\hline aCL2388Contig1 & At1g52230 & photosystem I reaction center subunit VI (PSI-H) & $9 \mathrm{E}-47$ \\
\hline aCL14Contig1 & At1g29910 & chlorophyll A-B binding protein 2 / LHCII type I (CAB-2) & $1 \mathrm{E}-132$ \\
\hline aCL1393Contig1 & At2g06520 & membrane protein, contains 2 transmembrane domains & $1 \mathrm{E}-19$ \\
\hline aCL129Contig1 & At2g03440 & nodulin-related & $6 \mathrm{E}-07$ \\
\hline aCL92Contig1 & At2g02400 & cinnamoyl-CoA reductase family & $1 \mathrm{E}-129$ \\
\hline aCL554Contig1 & At4g32940 & vacuolar processing enzyme gamma (gamma-VPE) & 0 \\
\hline aCL3Contig25 & At5g59310 & lipid transfer protein 4 (LTP4) & $4 \mathrm{E}-26$ \\
\hline aCL223Contig1 & At1g55670 & photosystem I reaction center subunit $\mathrm{V}$ (PSI-G) & $7 \mathrm{E}-58$ \\
\hline aCL2238Contig2 & At3g47470 & chlorophyll A-B binding protein 4 / LHCI type III (CAB-4) & $1 \mathrm{E}-128$ \\
\hline aCL13Contig1 & At3g43810 & calmodulin-7 (CAM7) & $4 \mathrm{E}-81$ \\
\hline aCL12Contig7 & At3g18280 & protease inhibitor/seed storage/lipid transfer protein (LTP) & $3 E-25$ \\
\hline aCL117Contig1 & At3g50820 & extrinsic subunit of photosystem II (PSBO-2) & $1 \mathrm{E}-153$ \\
\hline aCL105Contig2 & At4g33010 & glycine dehydrogenase (decarboxylating) & 0 \\
\hline aCL922Contig1 & At4g19860 & lecithin:cholesterol acyltransferase family protein (LACT) & 0 \\
\hline aCL7Contig9 & At3g15353 & metallothionein protein & $5 \mathrm{E}-18$ \\
\hline aCL79Contig2 & At5g19140 & auxin/aluminum-responsive protein & $1 \mathrm{E}-108$ \\
\hline aCL6Contig3 & At1g06680 & photosystem II oxygen-evolving complex 23 (OEC23) & $1 \mathrm{E}-114$ \\
\hline aCL6162Contig1 & At4g29090 & reverse transcriptase & $7 \mathrm{E}-13$ \\
\hline aCL5Contig7 & At1g05870 & expressed protein & $2 \mathrm{E}-49$ \\
\hline aCL5Contig32 & At2g05100 & chlorophyll A-B binding protein / LHCII type II (LHCB2) & $1 \mathrm{E}-132$ \\
\hline aCL5733Contig1 & At5g23120 & photosystem II stability/assembly factor (HCF136) & 7E-48 \\
\hline aCL4630Contig1 & At3g49340 & cysteine proteinase & $2 \mathrm{E}-91$ \\
\hline aCL460Contig1 & At1g73230 & nascent polypeptide-associated complex (NAC) & $1 \mathrm{E}-65$ \\
\hline aCL3Contig22 & At5g01750 & expressed protein & $7 E-69$ \\
\hline aCL3Contig1 & At1g60710 & aldo/keto reductase family protein & $1 \mathrm{E}-149$ \\
\hline aCL3244Contig1 & At3g44850 & protein kinase-related & 0 \\
\hline aCL3176Contig1 & At1g09340 & expressed protein & 0 \\
\hline aCL3117Contig1 & At5g26742 & similar to DEAD box RNA helicase & 0 \\
\hline aCL247Contig1 & At1g61520 & chlorophyll A-B binding protein / LHCl type III (LHCA3.1) & $1 \mathrm{E}-122$ \\
\hline aCL242Contig1 & At3g61470 & chlorophyll A-B binding protein (LHCA2) & $1 \mathrm{E}-120$ \\
\hline aCL2090Contig1 & At3g51880 & high mobility group protein alpha (HMGalpha) & 7E-32 \\
\hline aCL1995Contig2 & At1g17745 & similar to D-3-phosphoglycerate dehydrogenase (3-PGDH) & $1 \mathrm{E}-176$ \\
\hline aCL193Contig3 & At1g75270 & dehydroascorbate reductase & $3 E-95$ \\
\hline aCL158Contig1 & At2g19900 & encodes the malic enzyme (NADP-ME1) & 0 \\
\hline aCL1455Contig1 & At5g10980 & histone $\mathrm{H} 3$ & $5 \mathrm{E}-66$ \\
\hline aCL12Contig10 & At2g16600 & peptidyl-prolyl cis-trans isomerase / cyclophilin & $5 \mathrm{E}-77$ \\
\hline aCL1215Contig1 & At5g20860 & pectinesterase family protein & $1 \mathrm{E}-126$ \\
\hline aCL1042Contig1 & AtCg00150 & ATPase a subunit (ATPI) & $1 \mathrm{E}-108$ \\
\hline aCL1030Contig1 & At5g54770 & thiazole biosynthetic enzyme (ARA6) (THI1) (THI4) & $1 \mathrm{E}-150$ \\
\hline aCL9Contig8 & At4g02380 & late embryogenesis abundant 3 family protein (LEA3) & $1 \mathrm{E}-14$ \\
\hline aCL973Contig1 & At5g47390 & myb family transcription factor & $1 \mathrm{E}-114$ \\
\hline aCL924Contig1 & At1g06870 & signal peptidase & $4 \mathrm{E}-34$ \\
\hline aCL9187Contig1 & At1g03940 & transferase family protein & $9 \mathrm{E}-21$ \\
\hline aCL9162Contig1 & At2g06925 & phospholipase A2 family protein & $1 \mathrm{E}-20$ \\
\hline aCL835Contig2 & At4g13930 & glycine hydroxymethyltransferase & 0 \\
\hline aCL756Contig1 & At1g20340 & plastocyanin & $9 \mathrm{E}-49$ \\
\hline
\end{tabular}


aCL7530Contig1 aCL7518Contig1 aCL7268Contig1 aCL6Contig7 aCL6Contig1 aCL6782Contig1 aCL6673Contig1 aCL655Contig1 aCL642Contig1 aCL63Contig2 aCL5Contig16 aCL5703Contig1 aCL5670Contig1 aCL5624Contig1 aCL5533Contig1 aCL551Contig1 aCL5365Contig1 aCL5084Contig1 aCL4995Contig1 aCL48Contig1 aCL4866Contig1 aCL4648Contig1 aCL4590Contig1 aCL44Contig1 aCL43Contig4 aCL4074Contig1 aCL402Contig1 aCL3Contig2 aCL3Contig11 aCL3890Contig1 aCL36Contig2 aCL369Contig2 aCL369Contig1 aCL3263Contig1 aCL314Contig1 aCL3089Contig1 aCL2970Contig1 aCL289Contig1 aCL2887Contig1 aCL281Contig3 aCL2578Contig1 aCL245Contig2 aCL23Contig3 aCL2337Contig1 aCL21Contig2 aCL19Contig7 aCL19Contig2 aCL1971Contig1 aCL189Contig1 aCL1811Contig1 aCL1730Contig2 aCL172Contig1 aCL164Contig2 aCL15Contig1 aCL1583Contig1 aCL1543Contig1 aCL1513Contig1 aCL148Contig2 aCL1448Contig1 aCL1433Contig1 aCL13Contig4
At5g50810 At1g18070 At1g51590 At1g54410 At1g06680 At4g18130 At1g08820 At1g74470 At3g26650 At4g35090 At2g21660 At5g25080 At3g57540 At3g19170 At2g18690 At2g36690 At5g49945 At5g13630 At2g04360 At2g39730 At1g06460 At2g26580 At5g60160 At5g61820 At1g67090 At5g22580 At5g43940 At1g28330 At1g28330 At3g17930 At4g21960 At3g18280 At3g18280 At4g37300 At5g20700 At2g17800 At4g00660 At1g78680 At4g33380 At1g42970 At3g56940 At1g56220 At1g47128 At5g19620 At5g60390 At1g64230 At1g51200 At5g64040 At3g52880 At5g05690 At2g27680 At5g25610 At3g29075 At1g50570 At1g54680 At2g21580 At3g21055 At1g79040 At2g30980 At5g42820 At5g60360 mitochondrial import inner membrane translocase (TIM8) similar to elongation factor 1-alpha (EF-1-alpha) similar to mannosyl-oligosaccharide 1,2- $\alpha$-mannosidase dehydrin family protein

photosystem II oxygen-evolving complex 23 (OEC23) phytochrome E (PHYE)

similar to vesicle-associated membrane protein (VAMP) geranylgeranyl reductase

glyceraldehyde 3-phosphate dehydrogenase A (GAPA) catalase 2

glycine-rich RNA-binding protein (GRP7)

expressed protein

remorin family protein

Zinc metalloprotease pitrilysin subfamily A

expressed protein

oxidoreductase, $2 \mathrm{OG}-\mathrm{Fe}$ (II) oxygenase family protein

expressed protein

magnesium-chelatase subunit chlH $(\mathrm{CHLH})$

expressed protein

RuBisCO activase (RA)

$31.2 \mathrm{kDa}$ small heat shock family protein (hsp20) plant-specific transcription factor YABBY family protein aspartyl aminopeptidase

expressed protein

RuBisCO small subunit $1 \mathrm{~A}$ (RBCS-1A)

expressed protein

alcohol dehydrogenase class III (ADHIII)

dormancy-associated protein (DRM1)

dormancy-associated protein (DRM1)

expressed protein

peroxidase 42 (PER42) (P42) (PRXR1)

protease inhibitor/seed storage/lipid transfer protein (LTP)

protease inhibitor/seed storage/lipid transfer protein (LTP)

expressed protein

senescence-associated protein-related (SAG102)

Rac-like GTP-binding protein ARAC1/ATGP2

DEAD/DEAH box helicase

gamma-glutamyl hydrolase (GGH2)

expressed protein

glyceraldehyde-3-phosphate dehydrogenase B (GAPB)

dicarboxylate diiron protein, putative (CRD1)

dormancy/auxin associated family protein

cysteine proteinase (RD21A)

outer membrane OMP85 family protein

elongation factor 1-alpha (EF-1-alpha)

similar to ubiquitin-conjugating enzyme E2-17 kDa 9 (UBC9)

zinc finger (AN1-like) family protein

photosystem I reaction center subunit PSI-N

monodehydroascorbate reductase (NADH)

cytochrome P450 90A1 (CYP90A1)

aldo/keto reductase family protein

$6 \mathrm{E}-28$

2E-47

$1 \mathrm{E}-146$

$8 \mathrm{E}-09$

$3 \mathrm{E}-67$

2E-14

$1 \mathrm{E}-11$

0

$9 \mathrm{E}-47$

0

$8 \mathrm{E}-36$

4E-59

$4 \mathrm{E}-13$

9E-60

$1 \mathrm{E}-15$

4E-68

$3 \mathrm{E}-13$

$1 \mathrm{E}-159$

$1 \mathrm{E}-94$

4E-60

$4 \mathrm{E}-42$

$6 \mathrm{E}-18$

$1 \mathrm{E}-103$

$1 \mathrm{E}-144$

1E-77

1E-33

0

7E-39

$1 \mathrm{E}-38$

2E-27

$1 \mathrm{E}-157$

$6 \mathrm{E}-24$

$1 \mathrm{E}-23$

2E-24

3E-31

5E-98

1E-139

$1 \mathrm{E}-113$

$1 \mathrm{E}-122$

$1 \mathrm{E}-141$

$1 \mathrm{E}-26$

$\mathrm{E}-123$

dehydration-responsive protein (RD22)

glycine-rich protein

similar to $\mathrm{C} 2$ domain-containing protein

expressed protein

similar to 40S ribosomal protein S25 (RPS25E)

photosystem II $5 \mathrm{kD}$ protein (PSII-T)

photosystem II $10 \mathrm{kDa}$ polypeptide (PsbR)

shaggy-related protein kinase delta (ASK4)

U2 snRNP auxiliary factor small subunit

cysteine proteinase / AALP protein
0
$5 E-84$
$5 E-58$
$3 E-54$
0
0
$1 E-133$
$6 E-42$
$2 E-23$
$1 E-21$
$4 E-60$
$3 E-31$
$5 E-14$
$5 E-48$
0
$3 E-12$
$1 E-165$ 
aCL139Contig1 aCL138Contig3 aCL1328Contig1 aCL1306Contig1 aCL12Contig8 aCL1263Contig1 aCL1214Contig1 aCL117Contig2 aCL10Contig8 aCL105Contig1 aCL1019Contig2 aCL9Contig4 aCL9Contig21 aCL9Contig20 aCL9Contig16 aCL9Contig10 aCL971Contig1 aCL970Contig2 aCL95Contig4 aCL95Contig1 aCL956Contig3 aCL955Contig2 aCL9469Contig1 aCL9463Contig1 aCL9405Contig1 aCL9386Contig1 aCL936Contig1 aCL9367Contig1 aCL9335Contig1 aCL932Contig1 aCL931Contig1 aCL9319Contig1 aCL9312Contig1 aCL9295Contig1 aCL9283Contig1 aCL926Contig3 aCL9235Contig1 aCL914Contig1 aCL9142Contig1 aCL912Contig1 aCL910Contig1 aCL90Contig2 aCL9070Contig1 aCL9056Contig1 aCL9050Contig1 aCL9033Contig1 aCL9030Contig1 aCL89Contig1 aCL8943Contig1 aCL893Contig1 aCL88Contig1 aCL8865Contig1 aCL8829Contig1 aCL8807Contig1 aCL877Contig2 aCL8779Contig1 aCL8778Contig1 aCL8761Contig1 aCL8735Contig1 aCL8734Contig1 aCL8725Contig1
At1g69230

At5g08410

At5g45130

At4g36810

At3g18280

AtCg01310

At1g15820

At3g50820

At1g11430

At4g33010

At4g21580

At2g32520

At4g02380

At4g02380

At4g02380

AtCg00600

At4g25440

At5g66880

At5g51970

At5g51970

At5g42190

At1g56190

At3g17380

At5g01020

At5g59140

At5g58350

At3g02230

At5g58375

At5g18070

At3g56630

At4g27520

At3g52150

At2g16710

At1g25380

At1g06110

At1g25420

At1g79650

At5g13420

At5g61590

At1g15520

At5g07090

At5g17920

At2g31660

At3g06580

At2g18900

At5g58040

At4g12710

At3g14230

At1g06950

At5g07990

At1g18650

At3g09850

At5g38510

At1g72390

At3g62220

At5g58350

At5g06620

At2g46690

At2g31190

At1g08250

At1g64770 expressed protein

ferredoxin-thioredoxin reductase

Ras-related protein (RHA1)

geranylgeranyl pyrophosphate synthase (GGPS1)

protease inhibitor/seed storage/lipid transfer protein (LTP)

encodes a chloroplast ribosomal protein L2

chlorophyll A-B binding protein (LHCB6)

extrinsic subunit of photosystem II (PSBO-2)

plastid developmental protein DAG

glycine dehydrogenase (decarboxylating)

oxidoreductase, zinc-binding dehydrogenase family protein

dienelactone hydrolase family protein

late embryogenesis abundant 3 family protein (LEA3)

late embryogenesis abundant 3 family protein (LEA3)

late embryogenesis abundant 3 family protein (LEA3)

Cytochrome b6-f complex, subunit $\mathrm{V}$

WD-40 repeat family protein / zfwd1 protein (ZFWD1)

serine/threonine protein kinase

sorbitol dehydrogenase

sorbitol dehydrogenase

E3 ubiquitin ligase SCF complex subunit SKP1/ASK1 (At2)

phosphoglycerate kinase

meprin and TRAF homology domain-containing protein

protein kinase family protein

SKP1 family protein

protein kinase family protein

reversibly glycosylated polypeptide-1 (RGP1)

expressed protein

phosphoglucosamine mutase-related (PAGM)

cytochrome P450 (CYP94A1)

plastocyanin-like domain-containing protein

similar to $33 \mathrm{kDa}$ ribonucleoprotein

hesB-like domain-containing protein

mitochondrial substrate carrier family protein

F-box family protein

expressed protein

DNA repair protein RAD23

transaldolase

encodes a member of the ERF subfamily B-3

$A B C$ transporter family

40S ribosomal protein S4 (RPS4B)

encodes a METS protein

importin beta-2 subunit family protein

galactokinase (GAL1)

transducin family protein / WD-40 repeat family protein

fip1 motif-containing protein

armadillo/beta-catenin repeat family protein

encodes a member of the ERF subfamily B-3

encodes a protein thought to be a part of the translocon

flavonoid 3'-monooxygenase (F3'H)

glycosyl hydrolase family protein 17

D111/G-patch domain-containing protein

rhomboid family protein

expressed protein

serine/threonine protein kinase

protein kinase family protein

similar to SET domain-containing protein

auxin-responsive family protein

expressed protein

prephenate dehydratase family protein

expressed protein
$8 \mathrm{E}-18$

$4 \mathrm{E}-28$

$1 \mathrm{E}-98$

$1 \mathrm{E}-113$

$2 \mathrm{E}-23$

3E-75

$1 \mathrm{E}-116$

$1 \mathrm{E}-119$

8E-81

4E-32

$1 \mathrm{E}-143$

$1 \mathrm{E}-111$

1E-14

9E-15

9E-15

4E-13

$1 \mathrm{E}-171$

4E-67

1E-125

E-68

$1 \mathrm{E}-128$

1E-53

$1 \mathrm{E}-17$

6E-43

1E-136

0

3E-18

3E-71

1E-109

4E-39

$6 \mathrm{E}-72$

2E-44

1E-56

1E-06

2E-87

8E-68

0

3E-37

1E-140

1E-120

$1 \mathrm{E}-130$

9E-50

$1 \mathrm{E}-12$

9E-17

$1 \mathrm{E}-68$

$1 \mathrm{E}-112$

$1 \mathrm{E}-130$

$8 \mathrm{E}-35$

1E-44

1E-08

1E-20

$1 \mathrm{E}-169$

$4 \mathrm{E}-23$

2E-23

3E-30

1E-64

3E-57

1E-116 
aCL8721Contig1 aCL8680Contig1 aCL8669Contig1 aCL8646Contig1 aCL8570Contig1 aCL855Contig1 aCL8551Contig1 aCL8535Contig1 aCL8531Contig1 aCL850Contig1 aCL8448Contig1 aCL8320Contig1 aCL828Contig1 aCL8241Contig1 aCL822Contig1 aCL8225Contig1 aCL8210Contig1 aCL817Contig4 aCL8170Contig1 aCL8127Contig1 aCL808Contig1 aCL8082Contig1 aCL8059Contig1 aCL8050Contig1 aCL804Contig2 aCL8025Contig1 aCL8023Contig1 aCL8013Contig1 aCL8005Contig1 aCL79Contig3 aCL7920Contig1 aCL78Contig4 aCL7877Contig1 aCL7853Contig1 aCL784Contig1 aCL7849Contig1 aCL7837Contig1 aCL781Contig2 aCL7813Contig1 aCL7793Contig1 aCL777Contig1 aCL7756Contig1 aCL7748Contig1 aCL7736Contig1 aCL7724Contig1 aCL7718Contig1 aCL7709Contig1 aCL7697Contig1 aCL7696Contig1 aCL7682Contig1 aCL7670Contig1 aCL766Contig1 aCL7651Contig1 aCL7628Contig1 aCL7615Contig1 aCL7612Contig1 aCL7609Contig1 aCL7605Contig1 aCL759Contig2 aCL759Contig1 aCL7581Contig1
At2g43710 At3g55980 At1g78560 At2g36070 At4g27670 At1g17720 AtCg00440 At4g27840 At3g15190 At5g58770 At1g12360 At5g62050 At3g44110 At5g49890 At4g10040 At5g13630 At1g19660 At4g20260 At3g54970 At1g74190 At3g60820 At3g49800 AtMg00710 At3g17450 At5g62640 At3g15352 At1g35710 At1g29690 At4g24350 At5g19140 At1g26230 At5g21090 At5g47760 At5g19630 At4g20840 At1g47960 At5g52960 At2g39990 At4g13850 At4g22120 At1g17370 At5g14610 At2g02050 At3g06620 At2g35360 At5g41940 At1g76730 At1g30500 At1g63855 At2g29060 At3g56160 At5g50920 At3g59040 At3g25410 At3g52280 At2g37150 At5g64700 At5g55850 At1g26910 At1g26910 At1g62710 acyl-(acyl-carrier-protein) desaturase (SSI2)

zinc finger ( $\mathrm{CCCH}$-type) family protein

bile acid:sodium symporter family protein

mitochondrial import inner membrane translocase

$25.3 \mathrm{kDa}$ small heat shock protein (HSP25.3-P)

serine/threonine protein phosphatase $2 \mathrm{~A}$ ( $\mathrm{PP} 2 \mathrm{~A}$ )

$\mathrm{NADH}$ dehydrogenase D3 subunit

expressed protein

chloroplast $30 \mathrm{~S}$ ribosomal protein S20

dehydrodolichyl diphosphate synthase

cytokinesis-related Sec1 protein (KEULE)

OXA1 protein (OXA1)

DNAJ heat shock protein $(\mathrm{J} 3)$

chloride channel protein (CLC-c)

cytochrome c

magnesium-chelatase subunit chlH $(\mathrm{CHLH})$

similar to wound-responsive protein-related

similar to DREPP plasma membrane polypeptide-related

expressed protein

leucine-rich repeat family protein

20 s proteasome beta subunit $\mathrm{F} 1$ (PBF1)

BSD domain-containing protein

hypothetical protein

hAT dimerisation domain-containing protein

similar to proline-rich family protein

cytochrome $\mathrm{c}$ oxidase copper chaperone-related

leucine-rich repeat transmembrane protein kinase

encodes a protein with a domain similar to MACPF

phosphorylase family protein

auxin/aluminum-responsive protein

chaperonin

leucine-rich repeat protein

phosphoglycolate phosphatase

expressed protein

FAD-binding domain-containing protein

invertase/pectin methylesterase inhibitor family protein

expressed protein

eukaryotic translation initiation factor 3 subunit 5

glycine-rich RNA-binding protein (GRP2)

early-responsive to dehydration protein-related (ERD)

oligouridylate-binding protein

similar to DEAD box RNA helicase (DRH1)

NADH-ubiquinone oxidoreductase B18 subunit

protein kinase family protein

ubiquitin family protein

RabGAP/TBC domain-containing protein

5-formyltetrahydrofolate cyclo-ligase family protein

CCAAT-binding transcription factor (CBF-B/NF-YA)

expressed protein

scarecrow transcription factor family protein

expressed protein

similar to ATP-dependent Clp protease ATP-binding subunit

pentatricopeptide (PPR) repeat-containing protein

bile acid:sodium symporter family protein

DNA-binding bromodomain-containing protein

zinc finger (C3HC4-type RING finger) family protein

nodulin MtN21 family protein

similar to nitrate-responsive NOI protein

$1 \mathrm{E}-106$

$6 \mathrm{E}-06$

$1 \mathrm{E}-142$

$3 \mathrm{E}-57$

$4 \mathrm{E}-25$

$1 \mathrm{E}-59$

$5 \mathrm{E}-24$

$3 \mathrm{E}-30$

6E-36

$1 \mathrm{E}-113$

7E-39

$1 \mathrm{E}-174$

3E-53

$1 \mathrm{E}-60$

1E-153

7E-61

2E-41

2E-49

3E-53

1E-109

9E-21

1E-07

$1 \mathrm{E}-107$

1E-29

2E-22

$8 \mathrm{E}-30$

$1 \mathrm{E}-127$

3E-37

9E-97

5E-73

$5 \mathrm{E}-97$

$1 \mathrm{E}-137$

3E-85

4E-25

1E-50

$1 \mathrm{E}-120$

2E-34

$1 \mathrm{E}-101$

1E-162

4E-47

1E-42

1E-94

1E-57

$1 \mathrm{E}-110$

2E-30

7E-41

5E-68

$7 \mathrm{E}-43$

3E-27

0

$1 \mathrm{E}-129$

2E-71

5E-66

2E-09

9E-48

3E-19

$60 S$ ribosomal protein L10 (RPL10B) 1E-114

$60 S$ ribosomal protein $\mathrm{L} 10$ (RPL10B) $1 \mathrm{E}-114$

vacuolar processing enzyme beta (beta-VPE) 2E-32 
aCL7558Contig1 aCL7524Contig1 aCL7514Contig1 aCL7513Contig1 aCL7507Contig1 aCL7479Contig1 aCL7475Contig1 aCL7473Contig1 aCL744Contig1 aCL743Contig2 aCL7438Contig1 aCL7437Contig1 aCL7421Contig1 aCL7419Contig1 aCL73Contig1 aCL738Contig3 aCL738Contig1 aCL7389Contig1 aCL7382Contig1 aCL7371Contig1 aCL7364Contig1 aCL7330Contig1 aCL7325Contig1 aCL7322Contig1 aCL7313Contig1 aCL72Contig2 aCL7273Contig1 aCL725Contig1 aCL7254Contig1 aCL7199Contig1 aCL7164Contig1 aCL7152Contig1 aCL7136Contig1 aCL7110Contig1 aCL70Contig1 aCL7069Contig1 aCL705Contig2 aCL7045Contig1 aCL7044Contig1 aCL701Contig1 aCL7016Contig1 aCL7006Contig1 aCL6Contig22 aCL6Contig16 aCL698Contig2 aCL6983Contig1 aCL693Contig1 aCL6925Contig1 aCL6902Contig1 aCL6892Contig1 aCL688Contig1 aCL6887Contig1 aCL6882Contig1 aCL683Contig1 aCL6819Contig1 aCL6777Contig1 aCL6772Contig1 aCL674Contig2 aCL6690Contig1 aCL664Contig3 aCL664Contig1
At5g67290

At4g15560

At2g44140

At4g31040

At1g13245

At5g48450

At3g44880

At4g30790

At4g02340

At5g59890

At4g28760

At2g35795

At5g04870

At4g16360

At4g38970

At5g42050

At5g42050

At5g43750

At3g55070

At3g49290

At2g37970

At5g35695

At3g18990

At1g17020

At3g52860

At3g02780

At1g65700

At1g66330

At4g33510

At3g26020

At5g16110

At3g27925

At5g58330

At3g63030

At3g05500

At1g70580

At3g26740

At3g46900

At5g17170

At5g54110

At1g74970

At3g59660

At4g02380

At1g54410

At1g64090

At1g05570

At5g67300

At1g29900

At1g64470

At1g20760

At3g52850

At2g35110

At3g62240

At2g30020

At1g02680

At5g08480

At4g37800

At2g28000

At2g12400

At3g11940

At3g11940
FAD-dependent oxidoreductase family protein

1-deoxy-D-xylulose 5-phosphate synthase

autophagy 4a (APG4a)

proton extrusion protein-related

expressed protein

multi-copper oxidase type I family protein

Rieske (2Fe-2S) domain-containing protein

expressed protein

epoxide hydrolase

actin-depolymerizing factor 4 (ADF4)

expressed protein

DNAJ heat shock $\mathrm{N}$-terminal domain-containing protein

calcium-dependent protein kinase isoform AK1 (AK1)

5'-AMP-activated protein kinase beta-2 subunit

fructose-bisphosphate aldolase

expressed protein

expressed protein

expressed protein

expressed protein

expressed protein

SOUL heme-binding family protein

hypothetical protein

transcriptional factor B3 family protein

oxidoreductase, 2OG-Fe(II) oxygenase family protein

expressed protein

isopentenyl-diphosphate delta-isomerase II (IPP2)

similar to small nuclear ribonucleoprotein

senescence-associated family protein

2-dehydro-3-deoxyphosphoheptonate aldolase 2 (DHS2)

serine/threonine protein phosphatase 2A (PP2A) subunit B'

expressed protein

$5 \mathrm{E}-51$

2E-89

3E-49

1E-76

2E-10

$1 \mathrm{E}-142$

$1 \mathrm{E}-45$

$1 \mathrm{E}-112$

5E-53

2E-64

$4 \mathrm{E}-11$

3E-40

1E-69

7E-90

0

7E-98

3E-77

7E-64

1E-20

1E-22

8E-67

$6 \mathrm{E}-29$

$6 \mathrm{E}-40$

2E-51

1E-24

$1 \mathrm{E}-121$

1E-40

1E-129

1E-134

$1 \mathrm{E}-31$

DegP protease 2E-47

malate dehydrogenase (NADP)

methyl-CpG-binding domain-containing protein

rubber elongation factor (REF) family protein

similar to glutamate:glyoxylate aminotransferase 1 (GGT1)

light responsive protein-related /ccr protein

copper transporter (COPT1)

rubredoxin family protein

vesicle-associated membrane family protein (VAMP)

ribosomal protein S9 (RPS9)

C2 domain-containing protein

late embryogenesis abundant 3 family protein (LEA3)

dehydrin family protein

reticulon family protein (RTNLB3)

similar to glycosyl transferase family 48 protein

myb family transcription factor

carbamoyl-phosphate synthase family protein

ubiquitin family protein

calcium-binding EF hand family protein

vacuolar sorting receptor

$1 \mathrm{E}-150$

$8 \mathrm{E}-59$

$3 \mathrm{E}-54$

$7 \mathrm{E}-71$

$5 \mathrm{E}-30$

$4 \mathrm{E}-29$

3E-73

3E-79

3E-72

$6 \mathrm{E}-13$

$7 \mathrm{E}-17$

$8 \mathrm{E}-09$

$4 \mathrm{E}-72$

$1 \mathrm{E}-84$

7E-63

$1 \mathrm{E}-118$

$2 \mathrm{E}-53$

2E-89

similar to NCK-associated protein 1

zinc finger ( $\mathrm{C} 2 \mathrm{H} 2$ type) family protein

protein phosphatase 2C (PP2C)

transcription initiation factor IID (TFIID)

VQ motif-containing protein

xyloglucan:xyloglucosyl transferase

RuBisCO subunit binding-protein alpha subunit

expressed protein

40S ribosomal protein S5 (RPS5B)

40 S ribosomal protein S5 (RPS5B)
$1 \mathrm{E}-141$

3E-58

$1 \mathrm{E}-104$

$5 \mathrm{E}-41$

2E-43

$1 \mathrm{E}-14$

$1 \mathrm{E}-102$

$1 \mathrm{E}-27$

7E-98

$7 \mathrm{E}-98$ 
aCL6618Contig1 aCL6617Contig1 aCL6602Contig1 aCL6596Contig1 aCL6567Contig1 aCL6560Contig1 aCL6558Contig1 aCL654Contig1 aCL6546Contig1 aCL64Contig1 aCL6476Contig1 aCL646Contig1 aCL6447Contig1 aCL6424Contig1 aCL641Contig1 aCL6391Contig1 aCL6355Contig1 aCL6348Contig1 aCL632Contig1 aCL6289Contig1 aCL6272Contig1 aCL6259Contig1 aCL622Contig2 aCL6226Contig1 aCL61Contig2 aCL619Contig2 aCL6192Contig1 aCL6161Contig1 aCL6131Contig1 aCL6104Contig1 aCL6075Contig1 aCL6031Contig1 aCL5Contig3 aCL5Contig25 aCL5Contig23 aCL5Contig15 aCL5Contig1 aCL59Contig4 aCL599Contig2 aCL5982Contig1 aCL5964Contig1 aCL5961Contig1 aCL5939Contig1 aCL58Contig5 aCL5894Contig1 aCL588Contig2 aCL588Contig1 aCL5880Contig1 aCL5871Contig1 aCL585Contig2 aCL585Contig1 aCL5811Contig1 aCL579Contig2 aCL578Contig1 aCL5781Contig1 aCL5775Contig1 aCL5773Contig1 aCL5758Contig1 aCL5753Contig1 aCL5724Contig1 aCL5721Contig1
At3g11240

At5g41150

At3g11920

At5g55140

At3g12220

At2g31880

At3g50830

At2g29420

At4g28025

At1g65260

At1g79930

At5g56600

At1g79850

At3g19640

At4g27000

At4g26450

At1g21170

At3g59300

At4g38770

At1g27700

At1g70210

At2g46220

At1g05260

At4g10300

At5g23950

At3g49910

At4g02020

At1g55740

At3g12860

At1g03090

At4g00710

At1g01900

At5g47560

At2g21660

At2g21660

At3g22840

At5g47560

At2g27830

At2g17390

At2g41500

At1g75880

At3g50560

At1g54570

At4g23400

At1g21680

At4g38460

At4g38460

At5g20230

At4g24620

At1g79450

At1g79450

At4g29330

At5g39740

At3g12120

At5g58250

At4g24440

At2g42010

At3g22845

At4g11410

At1g42440

At1g08470
arginine-tRNA-protein transferase

$1 \mathrm{E}-52$

repair endonuclease (RAD1)

glutaredoxin-related

ribosomal protein L30 family protein

$\mathrm{E}-126$

$1 \mathrm{E}-124$

$7 \mathrm{E}-37$

serine carboxypeptidase $\mathrm{S} 10$ family protein

leucine-rich repeat transmembrane protein kinase

$8 \mathrm{E}-63$

$1 \mathrm{E}-56$

$5 \mathrm{E}-77$

$1 \mathrm{E}-55$

4E-34

$1 \mathrm{E}-112$

$1 \mathrm{E}-117$

$1 \mathrm{E}-58$

$1 \mathrm{E}-33$

$4 \mathrm{E}-55$

$6 \mathrm{E}-59$

$3 \mathrm{E}-46$

$1 \mathrm{E}-144$

$4 \mathrm{E}-21$

$1 \mathrm{E}-31$

$4 \mathrm{E}-55$

$1 \mathrm{E}-23$

$9 \mathrm{E}-73$

2E-90

$8 \mathrm{E}-47$

$3 \mathrm{E}-43$

$7 \mathrm{E}-54$

$1 \mathrm{E}-142$

$1 \mathrm{E}-138$

2E-80

2E-36

$1 \mathrm{E}-110$

$5 \mathrm{E}-28$

subtilase family protein

encodes a tonoplast malate/fumarate transporter

glycine-rich RNA-binding protein (GRP7)

glycine-rich RNA-binding protein (GRP7)

chlorophyll A-B binding family protein (ELIP)

encodes a tonoplast malate/fumarate transporter

expressed protein

ankyrin repeat family protein

WD-40 repeat family protein

family II extracellular lipase 1 (EXL1)

short-chain dehydrogenase/reductase (SDR) family protein

esterase/lipase/thioesterase family protein

major intrinsic family protein / MIP family protein

expressed protein

geranylgeranyl pyrophosphate synthase

geranylgeranyl pyrophosphate synthase

plastocyanin-like domain-containing protein

glucose-6-phosphate isomerase

LEM3 (ligand-effect modulator 3) family protein

LEM3 (ligand-effect modulator 3 ) family protein

Der1-like family protein

60 S ribosomal protein L5 (RPL5B)

omega- 6 fatty acid desaturase (FAD2)

expressed protein

transcription initiation factor IIA gamma chain (TFIIA-S)

phospholipase D beta 1 / PLD beta 1 (PLDBETA1)

emp24/gp25L/p24 protein-related

short-chain dehydrogenase/reductase (SDR) family protein

expressed protein

strictosidine synthase family protein
0

$2 \mathrm{E}-36$

5E-52

$3 \mathrm{E}-77$

1E-27

$1 \mathrm{E}-117$

$1 \mathrm{E}-145$

4E-72

$1 \mathrm{E}-103$

3E-88

$1 \mathrm{E}-143$

3E-86

1E-103

6E-99

$1 \mathrm{E}-18$

2E-89

$1 \mathrm{E}-103$

1E-65

3E-87

$1 \mathrm{E}-130$

7E-55

3E-50

$1 \mathrm{E}-140$

8E-54

8E-52

$1 \mathrm{E}-117$

1E-119 
aCL5713Contig1 aCL5709Contig1 aCL5706Contig1 aCL5695Contig1 aCL5687Contig1 aCL5671Contig1 aCL5665Contig1 aCL5662Contig1 aCL5654Contig1 aCL5646Contig1 aCL5641Contig1 aCL5634Contig1 aCL5607Contig1 aCL5601Contig1 aCL55Contig2 aCL5590Contig1 aCL5589Contig1 aCL5570Contig1 aCL5503Contig1 aCL548Contig1 aCL5488Contig1 aCL5453Contig1 aCL5448Contig1 aCL5440Contig1 aCL5437Contig1 aCL5434Contig1 aCL5422Contig1 aCL5413Contig1 aCL5407Contig1 aCL5405Contig1 aCL5383Contig1 aCL5381Contig1 aCL535Contig3 aCL5340Contig1 aCL5338Contig1 aCL5327Contig1 aCL52Contig3 aCL52Contig1 aCL5281Contig1 aCL5262Contig1 aCL5261Contig1 aCL5253Contig1 aCL5224Contig1 aCL5223Contig1 aCL5213Contig1 aCL5188Contig1 aCL517Contig2 aCL5178Contig1 aCL5170Contig1 aCL5158Contig1 aCL5148Contig1 aCL5143Contig1 aCL5140Contig1 aCL512Contig1 aCL5121Contig1 aCL5116Contig1 aCL508Contig1 aCL5079Contig1 aCL5060Contig1 aCL505Contig2 aCL504Contig1
At1g72160 At5g60580 At2g14835 At5g64840 At1g56420 At2g27920 At4g17390 At3g03920 At2g23600 At2g37410 At4g10330 At2g33250 At5g25140 At1g66670 At4g01850 At1g49320 At3g13080 At2g36970 At5g63320 At3g09770 At3g51980 At5g19150 At1g64355 At1g70660 At3g07630 At3g18890 At3g12760 At1g30360 At1g31010 At5g19420 At5g53350 At2g25920 At3g10190 At1g73940 At3g19980 At5g58220 At3g01120 At3g01120 At5g03740 At3g22200 At3g61490 At1g17020 At5g67130 At5g09930 At4g02630 At2g46820 At2g18050 At1g32230 At3g11730 At3g27310 At3g47550 At4g15920 At2g24050 At1g71880 At1g71480 At3g11780 At3g58610 At1g59950 At3g26090 At2g02010 At5g58240 phosphoglyceride transfer family protein (SEC14)

$1 \mathrm{E}-12$ zinc finger (C3HC4-type RING finger) family protein

$1 \mathrm{E}-31$ zinc finger (C3HC4-type RING finger) family protein 1E-141 $A B C$ transporter family protein expressed protein serine carboxypeptidase $\mathrm{S} 10$ family protein 60S ribosomal protein L15 (RPL15B)

Gar1 RNA-binding region family protein hydrolase mitochondrial import inner membrane translocase (TIM17) glycine-rich protein expressed protein cytochrome $\mathrm{P} 450$ family protein ATP-dependent Clp protease proteolytic subunit (ClpP3) S-adenosylmethionine synthetase 2 (SAM2) BURP domain-containing protein $A B C$ transporter family protein UDP-glucoronosyl/UDP-glucosyl transferase family protein similar to DNA-binding bromodomain-containing protein zinc finger (C3HC4-type RING finger) family protein expressed protein carbohydrate kinase family expressed protein ubiquitin-conjugating enzyme family protein prephenate dehydratase family protein expressed protein expressed protein early-responsive to dehydration stress protein (ERD4)

$1 \mathrm{E}-105$

$8 \mathrm{E}-52$

$1 \mathrm{E}-139$

$1 \mathrm{E}-90$

$9 \mathrm{E}-42$

$3 \mathrm{E}-46$

$1 \mathrm{E}-70$

$4 \mathrm{E}-11$

$8 \mathrm{E}-09$

$7 \mathrm{E}-54$

$5 \mathrm{E}-87$

3E-34

$1 \mathrm{E}-136$

$1 \mathrm{E}-161$

$5 \mathrm{E}-17$

$1 \mathrm{E}-105$

$1 \mathrm{E}-121$

$1 \mathrm{E}-94$

3E-50

$4 \mathrm{E}-68$

$1 \mathrm{E}-136$

$2 \mathrm{E}-58$

$1 \mathrm{E}-40$

$4 \mathrm{E}-86$ expressed protein $1 \mathrm{E}-25$ zinc finger protein $1 \mathrm{E}-130$

ATP-dependent Clp protease ATP-binding subunit ClpX1 $1 \mathrm{E}-29$ expressed protein $1 \mathrm{E}-55$ calmodulin $1 \mathrm{E}-46$

expressed protein

serine/threonine protein phosphatase (STPP)

expressed protein

cystathionine gamma-synthase (CGS)

cystathionine gamma-synthase (CGS)

zinc finger $(\mathrm{C} 2 \mathrm{H} 2$ type) family protein

4-aminobutyrate aminotransferase

glycoside hydrolase family 28 protein

oxidoreductase, 2OG-Fe(II) oxygenase family protein

expressed protein

ABC transporter family protein

protein kinase family protein

expressed protein

histone H1-3 (HIS1-3)

WWE domain-containing protein (CEO)

Ras-related GTP-binding protein

expressed protein

zinc finger (C3HC4-type RING finger) family protein

nodulin MtN3 family protein

MIF4G domain-containing protein

sucrose transporter (SUC1)

nuclear transport factor 2 (NTF2) family protein

MD-2-related lipid recognition domain-containing protein

ketol-acid reductoisomerase

aldo/keto reductase

expressed protein

$4 \mathrm{E}-39$

$1 \mathrm{E}-105$

$1 \mathrm{E}-89$

$1 \mathrm{E}-79$

0

$3 \mathrm{E}-24$

$4 \mathrm{E}-92$

$1 \mathrm{E}-170$

2E-51

$1 \mathrm{E}-154$

$1 \mathrm{E}-101$

$4 \mathrm{E}-83$

$1 \mathrm{E}-40$

9E-24

9E-57

3E-98

3E-68

$4 \mathrm{E}-77$

$7 \mathrm{E}-58$

3E-74

$1 \mathrm{E}-177$

$5 \mathrm{E}-54$

3E-56

$5 \mathrm{E}-26$

2E-97

$6 \mathrm{E}-95$

glutamate decarboxylase

bis(5'-adenosyl)-triphosphatase

$6 \mathrm{E}-55$ 
aCL5023Contig1 aCL5001Contig1 aCL4Contig31 aCL4Contig29 aCL4Contig25 aCL4962Contig1 aCL4949Contig1 aCL493Contig1 aCL4921Contig2 aCL48Contig3 aCL4899Contig1 aCL4893Contig1 aCL4880Contig1 aCL4868Contig1 aCL4860Contig1 aCL4838Contig1 aCL4830Contig1 aCL4829Contig1 aCL4826Contig1 aCL4823Contig1 aCL480Contig1 aCL477Contig2 aCL474Contig1 aCL4746Contig1 aCL473Contig1 aCL472Contig3 aCL472Contig1 aCL4722Contig1 aCL4712Contig1 aCL4708Contig1 aCL4705Contig1 aCL46Contig3 aCL4685Contig1 aCL4665Contig1 aCL4657Contig1 aCL4650Contig1 aCL4635Contig1 aCL462Contig1 aCL4623Contig1 aCL4614Contig1 aCL4608Contig1 aCL4607Contig1 aCL45Contig2 aCL4595Contig1 aCL4593Contig1 aCL4589Contig1 aCL4562Contig1 aCL4558Contig1 aCL4551Contig1 aCL4542Contig1 aCL4540Contig1 aCL4520Contig1 aCL4515Contig1 aCL4509Contig1 aCL44Contig4 aCL44Contig2 aCL4472Contig1 aCL4463Contig1 aCL4460Contig1 aCL4446Contig1 aCL4445Contig1
At2g27050

At2g45550

At4g05320

At5g03240

At5g20620

At5g04600

At2g36910

At3g12390

At3g15095

At2g39730

At1g16880

At5g60840

At1g73950

At1g28050

At4g01050

At1g76080

At2g06530

At5g48870

At3g26580

At4g32260

At1g52760

At4g17900

At3g19290

At3g46460

At1g19140

At1g51090

At4g16380

At2g36880

At5g17920

At5g63530

At2g23940

At1g24020

At5g41600

At4g29090

AtCg00510

At1g50380

At4g36910

At2g47110

At2g45670

At5g22460

At3g07720

At1g14510

At3g48690

At1g71090

At4g17600

At1g07040

AtCg01100

At5g26360

At3g27890

At4g25670

At4g29735

At1g49410

At3g16500

At4g03520

At3g10260

At3g10260

At2g31200

At3g05270

At3g06050

At3g52960

At2g27290 ethylene-insensitive3-like1 (EIL1)

$7 \mathrm{E}-22$

$1 \mathrm{E}-51$

tochrome $\mathrm{P} 450$ family protein

polyubiquitin (UBQ10)

similar to polyubiquitin (UBQ10)

polyubiquitin (UBQ4)

RNA recognition motif (RRM)-containing protein

multidrug resistance P-glycoprotein (PGP1)

nascent polypeptide associated complex (alpha-NAC)

expressed protein

RuBisCO activase

uridylyltransferase-related

expressed protein

zinc finger (C3HC4-type RING finger) family protein

zinc finger (B-box type) family protein

hydroxyproline-rich glycoprotein family protein

thioredoxin family protein

SNF7 family protein

small nuclear ribonucleoprotein

expressed protein

ATP synthase family

esterase/lipase/thioesterase family protein

zinc-binding family protein

ABA-responsive element-binding protein 2 (AREB2)

ubiquitin-conjugating enzyme 13 (UBC13)

expressed protein

heavy-metal-associated domain-containing protein

expressed protein

S-adenosylmethionine synthetase

encodes METS protein

copper chaperone $(\mathrm{CCH})$-related

expressed protein

Bet $v$ I allergen family protein

reticulon family protein (RTNLB4)

reverse transcriptase

PSI I protein

prolyl oligopeptidase family protein

CBS domain-containing protein

ubiquitin extension protein 6 (UBQ6)

calcineurin B subunit-related

esterase/lipase/thioesterase family protein

kelch repeat-containing protein

PHD finger family protein

expressed protein

auxin efflux carrier family protein

lil3 protein

expressed protein

NADH dehydrogenase ND1

chaperonin

NADPH-dependent FMN reductase family protein

expressed protein

expressed protein

expressed protein

auxin-responsive AUX/IAA family protein

thioredoxin M-type 2 (TRX-M2)

reticulon family protein

reticulon family protein

actin-depolymerizing factor 6 (ADF6)

expressed protein

encodes a mitochondrial peroxiredoxin

peroxiredoxin type 2

expressed protein
$1 \mathrm{E}-125$

$1 \mathrm{E}-168$

$6 \mathrm{E}-81$

$4 \mathrm{E}-60$

$7 \mathrm{E}-55$

$5 \mathrm{E}-25$

$1 \mathrm{E}-169$

4E-99

$7 \mathrm{E}-11$

4E-68

$6 \mathrm{E}-38$

$5 \mathrm{E}-35$

7E-65

8E-97

1E-41

7E-57

2E-49

$1 \mathrm{E}-162$

1E-75

3E-76

1E-73

4E-96

$1 \mathrm{E}-16$

6E-12

1E-142

$1 \mathrm{E}-179$

$6 \mathrm{E}-36$

3E-68

4E-06

2E-84

1E-28

8E-10

2E-21

$4 \mathrm{E}-83$

7E-68

$5 \mathrm{E}-68$

2E-88

3E-50

2E-15

2E-96

$1 \mathrm{E}-125$

8E-65

$1 \mathrm{E}-134$

2E-81

$1 \mathrm{E}-130$

2E-76

2E-33

$1 \mathrm{E}-17$

3E-14

3E-61

3E-39

1E-75

7E-66

1E-60

1E-41

5E-82

9E-74

7E-44 
aCL4424Contig1 aCL4423Contig1 aCL440Contig1 aCL43Contig2 aCL4395Contig1 aCL438Contig2 aCL4360Contig1 aCL4355Contig1 aCL4354Contig1 aCL4319Contig1 aCL4318Contig1 aCL4288Contig1 aCL4283Contig1 aCL4274Contig1 aCL426Contig1 aCL4261Contig1 aCL4244Contig1 aCL422Contig1 aCL4218Contig1 aCL4187Contig1 aCL4180Contig1 aCL4174Contig1 aCL4159Contig1 aCL4152Contig1 aCL4148Contig1 aCL4135Contig1 aCL4116Contig2 aCL4114Contig1 aCL410Contig2 aCL4006Contig2 aCL4004Contig1 aCL3Contig5 aCL3Contig4 aCL3Contig35 aCL3Contig18 aCL398Contig2 aCL398Contig1 aCL3964Contig1 aCL3963Contig1 aCL3949Contig1 aCL3934Contig1 aCL391Contig1 aCL3916Contig1 aCL390Contig2 aCL38Contig1 aCL388Contig1 aCL3889Contig2 aCL3887Contig1 aCL3882Contig1 aCL386Contig1 aCL3863Contig1 aCL385Contig1 aCL3858Contig1 aCL3856Contig1 aCL3855Contig1 aCL384Contig1 aCL3840Contig1 aCL3830Contig2 aCL3829Contig1 aCL3818Contig1 aCL3804Contig1
At1g64980

At2g29530

At1g49760

At1g67090

At3g27090

At3g22890

At5g16620

At3g27950

At3g07565

At3g61220

At1g04260

At5g04560

At3g12080

At2g41430

At1g10830

At1g10760

At3g16920

At4g01610

At1g75280

At4g34590

At1g34210

At2g43780

At5g14240

At5g06060

At2g45850

At5g13590

At5g53370

At3g54250

At1g02880

At5g24470

At1g69360

At5g59310

At1g60710

At2g17200

At1g28330

At5g46110

At5g46110

At2g26510

At1g08530

At1g68090

At1g13560

At1g70330

At3g15850

At2g32670

At5g54160

At2g18730

At1g14900

At2g45740

At1g22620

At5g47120

At1g78630

At1g48910

At2g27040

At3g48800

At4g28770

At3g47850

At1g23310

At5g61600

At2g25770

At1g63940

At5g22950 expressed protein

mitochondrial import inner membrane translocase (TIM10)

polyadenylate-binding protein (PABP)

RuBisCO small subunit $1 \mathrm{~A}$ (RBCS-1A)

expressed protein

sulfate adenylyltransferase 1 / ATP-sulfurylase 1 (APS1)

similar to chloroplast protein translocon component Tic40

early nodule-specific protein

expressed protein

short-chain dehydrogenase/reductase (SDR) family protein

prenylated rab acceptor (PRA1) family protein

DEMETER protein (DME)

GTP-binding family protein

dehydration-induced protein (ERD15)

sodium symporter-related

starch excess protein (SEX1)

glycoside hydrolase family 19 protein

cathepsin B-like cysteine protease

isoflavone reductase

bZIP transcription factor family protein

somatic embryogenesis receptor-like kinase 2 (SERK2)

expressed protein

expressed protein

tropinone reductase

DNA-binding family protein

expressed protein

pectinesterase family protein

mevalonate diphosphate decarboxylase

thiamin pyrophosphokinase

pseudo-response regulator 5 (APRR5)

expressed protein

lipid transfer protein 4 (LTP4)

aldo/keto reductase family protein

ubiquitin family protein

dormancy-associated protein (DRM1)

phosphate/triose-phosphate translocator

phosphate/triose-phosphate translocator

xanthine/uracil permease family protein

expressed protein

calcium-binding protein annexin 5 (ANN5)

aminoalcoholphosphotransferase (AAPT1)

equilibrative nucleoside transporter family protein

fatty acid desaturase family protein (ADS1)

synaptobrevin family protein

quercetin 3-O-methyltransferase 1(OMT1)

diacylglycerol kinase

high-mobility-group protein / HMG-I/Y protein

4E-76

2E-36

5E-32

$1 \mathrm{E}-113$

$1 \mathrm{E}-160$

1E-21

$1 \mathrm{E}-111$

$1 \mathrm{E}-102$

6E-95

$8 \mathrm{E}-42$

0

4E-61

6E-13

$1 \mathrm{E}-129$

$1 \mathrm{E}-146$

$1 \mathrm{E}-150$

5E-79

$1 \mathrm{E}-133$

3E-34

5E-19

4E-81

8E-71

9E-54

2E-47

$1 \mathrm{E}-115$

$1 \mathrm{E}-131$

6E-76

$4 \mathrm{E}-23$

2E-90

4E-26

$1 \mathrm{E}-159$

$1 \mathrm{E}-130$

4E-39

1E-115

$1 \mathrm{E}-173$

2E-49

3E-91

0

1E-147

5E-81

4E-86

2E-91

$1 \mathrm{E}-20$

similar to peroxisomal biogenesis factor 11 family protein $\quad 1 \mathrm{E}-106$

SAC domain phosphoinositide (3,5)P2 phosphatase 1E-129

Bax inhibitor-1 putative / BI-1 putative 4E-89

ribosomal protein $\mathrm{L} 13$ family protein $2 \mathrm{E}-72$

flavin-containing monooxygenase family protein $\quad 1 \mathrm{E}-110$

PAZ domain-containing protein

sterile alpha motif (SAM) domain-containing protein $\quad 1 E-31$

expressed protein

expressed protein

glutamate:glyoxylate aminotransferase 1 (GGT1)

encodes a member of ERF/AP2 transcription factor family

expressed protein

monodehydroascorbate reductase

SNF7 family protein
$1 \mathrm{E}-65$

2E-39

$1 \mathrm{E}-164$

$4 \mathrm{E}-32$

$3 \mathrm{E}-32$

9E-99 
aCL3795Contig2 aCL3788Contig1 aCL3787Contig1 aCL3776Contig1 aCL3764Contig1 aCL3762Contig1 aCL3761Contig1 aCL375Contig2 aCL3758Contig2 aCL3741Contig1 aCL3734Contig1 aCL3716Contig1 aCL36Contig3 aCL369Contig3 aCL3697Contig1 aCL3690Contig1 aCL3689Contig1 aCL3682Contig1 aCL3650Contig1 aCL3638Contig1 aCL3637Contig1 aCL3625Contig1 aCL3622Contig1 aCL3620Contig1 aCL3589Contig1 aCL3567Contig1 aCL3558Contig1 aCL3550Contig1 aCL3521Contig1 aCL3498Contig1 aCL3487Contig1 aCL3461Contig1 aCL3457Contig1 aCL3450Contig1 aCL3436Contig1 aCL3429Contig1 aCL341Contig1 aCL334Contig1 aCL3343Contig1 aCL3324Contig1 aCL3303Contig1 aCL329Contig2 aCL329Contig1 aCL3292Contig1 aCL3290Contig1 aCL3276Contig1 aCL3260Contig1 aCL3251Contig1 aCL3250Contig1 aCL324Contig2 aCL3241Contig1 aCL3236Contig1 aCL3233Contig1 aCL322Contig1 aCL3214Contig1 aCL3210Contig1 aCL319Contig1 aCL317Contig1 aCL3172Contig1 aCL3166Contig1 aCL315Contig1
At3g13510 At1g56300

At5g40760

At5g02810

At2g04700

At5g38650

At2g29420

At2g46080

At3g58500

At2g17410

At4g01150

At4g31880

At4g21960

At3g18280

At3g54050

At2g16250

At1g27950

At3g02790

At4g01310

At3g59670

At1g74270

At3g58170

At5g11760

At4g35450

At2g33730

At2g26440

At4g13500

At3g01990

At1g18800

At1g50250

At1g27650

At5g05000

At3g27925

At3g08510

At5g13030

At2g25810

At2g39670

At3g16640

At5g54160

At2g04900

At2g04030

At1g31330

At1g31330

At3g23490

At3g15840

At1g52740

At1g78020

At4g08170

At1g17620

At3g58180

At1g33970

At4g36900

At5g02270

At1g03400

At4g18100

At4g32410

At1g25550

At4g30690

At5g41990

At5g55310

At5g62790 expressed protein

DNAJ heat shock $\mathrm{N}$-terminal domain-containing protein

encodes a cytosolic glucose-6-phosphate dehydrogenase

pseudo-response regulator 7 (APRR7)

ferredoxin thioredoxin reductase family protein

proteasome maturation factor UMP1 family protein

glutathione S-transferase

expressed protein

serine/threonine protein phosphatase PP2A-4 (PP2A4)

ARID/BRIGHT DNA-binding domain-containing protein

expressed protein

expressed protein

peroxidase 42 (PER42) (P42) (PRXR1)

protease inhibitor/seed storage/lipid transfer protein (LTP)

fructose-1,6-bisphosphatase

leucine-rich repeat transmembrane protein kinase

lipid transfer protein-related

zinc finger ( $\mathrm{C} 2 \mathrm{H} 2$ type) family protein

ribosomal protein $\mathrm{L} 5$ family protein

expressed protein

60S ribosomal protein L35a (RPL35aC)

Bet1-like SNARE 1-1 (BET11)

expressed protein

ankyrin repeat family protein (AFT)

DEAD box RNA helicase

pectinesterase family protein

expressed protein

ACT domain-containing protein (ACR6)

nucleosome assembly protein (NAP) family protein

encodes an FTSH protease

U2 snRNP auxiliary factor small subunit

translocate of chloroplast 34 (TOC34)

DegP protease

phosphoinositide-specific phospholipase $\mathrm{C}$ family protein

expressed protein

tonoplast intrinsic protein

radical SAM domain-containing protein

translationally controlled tumor family protein

quercetin 3-O-methyltransferase 1 (OMT1)

expressed protein

heat shock protein

photosystem I reaction center subunit III family protein

photosystem I reaction center subunit III family protein

cyanate lyase family

expressed protein

histone $\mathrm{H} 2 \mathrm{~A}$

senescence-associated protein-related (SAG102)

inositol 1,3,4-trisphosphate 5/6-kinase family protein

expressed protein

PBS lyase HEAT-like repeat-containing protein

similar to avirulence induced gene (AIG1)

encodes a member of ERF/AP2 transcription factor family

$A B C$ transporter family protein

2-oxoglutarate-dependent dioxygenase

1E-109

$5 \mathrm{E}-55$

$3 E-25$

8E-59

1E-53

5E-48

$1 \mathrm{E}-123$

7E-79

$1 \mathrm{E}-40$

2E-41

$5 \mathrm{E}-40$

$1 \mathrm{E}-158$

2E-23

$1 \mathrm{E}-103$

$1 \mathrm{E}-105$

1E-31

4E-43

1E-109

9E-49

2E-57

1E-52

7E-11

7E-14

2E-86

8E-37

$1 \mathrm{E}-171$

7E-99

0

1E-95

$1 \mathrm{E}-119$

1E-62

6E-97

1E-120

$1 \mathrm{E}-101$

$1 \mathrm{E}-136$

2E-69

$1 \mathrm{E}-163$

5 E-43

0

3E-79

4E-79

$4 \mathrm{E}-57$

7E-65

1E-44

2E-21

$1 \mathrm{E}-131$

7E-53

$1 \mathrm{E}-106$

$7 \mathrm{E}-57$

9E-46

1E-138

7E-82

2E-57

cellulose synthase, catalytic subunit

myb family transcription factor

translation initiation factor 3 (IF-3) family protein

protein kinase family protein

DNA topoisomerase I

1-deoxy-D-xylulose 5-phosphate reductoisomerase (DXR)
0
$3 \mathrm{E}-77$

$7 \mathrm{E}-82$

$1 \mathrm{E}-60$

$1 \mathrm{E}-173$ 
aCL3157Contig1 aCL3155Contig1 aCL314Contig2 aCL3144Contig1 aCL3140Contig1 aCL3133Contig2 aCL3133Contig1 aCL3121Contig1 aCL3118Contig1 aCL3113Contig1 aCL310Contig2 aCL30Contig1 aCL3096Contig1 aCL3063Contig1 aCL304Contig1 aCL3042Contig1 aCL3041Contig1 aCL3030Contig1 aCL302Contig2 aCL3025Contig1 aCL3017Contig1 aCL2Contig14 aCL2Contig13 aCL29Contig4 aCL2997Contig1 aCL2995Contig1 aCL297Contig2 aCL297Contig1 aCL2963Contig1 aCL2953Contig2 aCL2936Contig1 aCL2935Contig1 aCL292Contig1 aCL2924Contig1 aCL2911Contig1 aCL2903Contig1 aCL2891Contig1 aCL2874Contig1 aCL2872Contig1 aCL2870Contig1 aCL2866Contig1 aCL285Contig2 aCL2845Contig1 aCL2840Contig1 aCL2832Contig1 aCL2820Contig1 aCL281Contig1 aCL2805Contig2 aCL2801Contig1 aCL27Contig2 aCL27Contig1 aCL2799Contig1 aCL2795Contig1 aCL2785Contig1 aCL2767Contig1 aCL2758Contig1 aCL273Contig1 aCL2738Contig1 aCL2732Contig2 aCL2722Contig1 aCL26Contig9
At2g46970

At5g57040

At5g20700

At5g02502

At4g02770

At3g16370

At3g16370

At4g03560

At3g06190

At5g05100

At4g26850

At2g33150

At5g65220

At5g57970

At5g15490

At1g60420

At2g43420

At4g27435

At5g42520

At4g37930

At5g11710

At4g34350

At4g34350

At3g04120

At1g23740

At1g76010

At1g17860

At1g17860

At5g57300

At5g66190

At5g60570

At5g20160

At5g14970

At5g64030

At5g01590

At1g59950

At5g24690

At4g00755

At4g12800

At1g69120

At1g35420

At3g57490

At $4 \mathrm{~g} 03080$

At4g36980

At4g16380

At1g59990

At1g42970

At2g42750

At1g05070

At5g13930

At1g73990

At1g79590

At5g56940

At5g62360

At3g49680

At4g14342

At5g33370

At1g75780

At1g32210

At5g35630

At5g39670 basic helix-loop-helix (bHLH) protein

lactoylglutathione lyase family protein

senescence-associated protein-related (SAG102)

expressed protein

photosystem I reaction center subunit II (PSI-D)

GDSL-motif lipase/hydrolase family protein

GDSL-motif lipase/hydrolase family protein

two-pore calcium channel (TPC1)

speckle-type $\mathrm{POZ}$ protein-related

expressed protein

expressed protein

acetyl-CoA C-acyltransferase

ribosomal protein $L 29$ family protein

similar to methyladenine glycosylase family protein

UDP-glucose 6-dehydrogenase (UDPGDH)

DC1 domain-containing protein

3-beta hydroxysteroid dehydrogenase family protein

expressed protein

expressed protein

glycine hydroxymethyltransferase (SHM1)

epsin N-terminal homology (ENTH) domain

ISPH (nonmevalonate pathway of isoprenoid biosynthesis)

ISPH (nonmevalonate pathway of isoprenoid biosynthesis)

glyceraldehyde-3-phosphate dehydrogenase (GAPC)

oxidoreductase, zinc-binding dehydrogenase family protein

expressed protein

trypsin and protease inhibitor family protein

trypsin and protease inhibitor family protein

UbiE/COQ5 methyltransferase family protein

ferredoxin--NADP $(+)$ reductase

kelch repeat-containing F-box family protein

ribosomal protein $\mathrm{L} 7 \mathrm{Ae} / \mathrm{L} 30 \mathrm{e} / \mathrm{S} 12 \mathrm{e} / \mathrm{Gadd} 45$ family protein

expressed protein

dehydration-responsive protein-related (ERD3)

expressed protein

aldo/keto reductase

expressed protein

F-box family protein

photosystem I reaction center subunit XI (PSI-L)

floral homeotic protein APETALA1 (AP1)

dienelactone hydrolase family protein

40 s ribosomal protein S2 (RPS2D)

kelch repeat-containing phosphoesterase family protein

expressed protein

expressed protein

DEAD/DEAH box helicase

glyceraldehyde-3-phosphate dehydrogenase B (GAPB)

DNAJ heat shock $\mathrm{N}$-terminal domain-containing protein

expressed protein

chalcone synthase / naringenin-chalcone synthase

peptidase $\mathrm{U} 7$ family protein

similar to syntaxin 51 (SYP51)

7E-31

7E-70

3E-31

$1 \mathrm{E}-11$

3E-78

$1 \mathrm{E}-144$

$1 \mathrm{E}-128$

$8 \mathrm{E}-96$

$2 \mathrm{E}-42$

0

3E-87

$8 \mathrm{E}-41$

$1 \mathrm{E}-111$

$9 \mathrm{E}-50$

2E-95

$8 \mathrm{E}-63$

3E-80

$1 \mathrm{E}-131$

$1 \mathrm{E}-150$

$1 \mathrm{E}-119$

$1 \mathrm{E}-168$

5E-59

$5 \mathrm{E}-60$

1E-15

9E-14

$1 \mathrm{E}-122$

$1 \mathrm{E}-170$

8E-63

5E-54

$6 \mathrm{E}-83$

0

1E-172

1E-119

$7 \mathrm{E}-48$

2E-97

1E-85

$6 \mathrm{E}-63$

1E-94

1E-112

$$
0
$$

$1 \mathrm{E}-110$

4E-17

$2 \mathrm{E}-80$

3E-85

$8 \mathrm{E}-47$

E-38

$6 \mathrm{E}-88$

5E-57

invertase/pectin methylesterase inhibitor family protein $3 E-40$

branched-chain amino acid transaminase 3 (BCAT3) 1E-158

pre-mRNA splicing factor $10 \mathrm{kDa}$ subunit

GDSL-motif lipase/hydrolase family protein

$4 \mathrm{E}-41$

$1 \mathrm{E}-147$

tubulin beta-1 chain (TUB1)

$8 \mathrm{E}-53$

defender against cell death 1 (DAD1)

similar to glutamine synthetase

0

$7 \mathrm{E}-11$ 


\begin{tabular}{|c|c|c|c|}
\hline aCL26Contig1 & At5g26990 & drought-responsive family protein & $3 \mathrm{E}-56$ \\
\hline aCL269Contig1 & At2g22780 & malate dehydrogenase & $1 \mathrm{E}-170$ \\
\hline aCL2696Contig1 & At3g22630 & $20 S$ proteasome beta subunit $\mathrm{D}$ (PBD1) & $3 E-99$ \\
\hline aCL2691Contig1 & At5g12250 & tubulin beta-6 chain (TUB6) & 0 \\
\hline aCL268Contig1 & At3g53020 & regulated by TCP20 & $1 \mathrm{E}-53$ \\
\hline aCL2668Contig1 & At3g49990 & expressed protein & $2 \mathrm{E}-36$ \\
\hline aCL265Contig2 & At5g20720 & $20 \mathrm{kDa}$ chaperonin (CPN21) & $1 \mathrm{E}-98$ \\
\hline aCL2657Contig1 & At1g47420 & expressed protein & $5 \mathrm{E}-70$ \\
\hline aCL264Contig1 & At2g02180 & tobamovirus multiplication protein 3 (TOM3) & $1 \mathrm{E}-111$ \\
\hline aCL2637Contig1 & At1g79420 & expressed protein & $1 \mathrm{E}-130$ \\
\hline aCL2630Contig1 & At2g18290 & anaphase-promoting complex, subunit 10 family & $7 \mathrm{E}-91$ \\
\hline aCL2623Contig1 & At1g52570 & phospholipase D alpha 2 (PLD2) & 0 \\
\hline aCL261Contig1 & At4g39235 & expressed protein & $1 \mathrm{E}-27$ \\
\hline aCL2617Contig1 & At3g61320 & expressed protein & $8 \mathrm{E}-68$ \\
\hline aCL2615Contig1 & At3g51630 & protein kinase family protein & $1 \mathrm{E}-143$ \\
\hline aCL2591Contig2 & At2g20360 & expressed protein & $1 \mathrm{E}-155$ \\
\hline aCL2579Contig2 & At1g03130 & photosystem I reaction center subunit II (PSI-D) & $2 \mathrm{E}-82$ \\
\hline aCL2565Contig1 & At1g56700 & pyrrolidone-carboxylate peptidase family protein & 3E-92 \\
\hline aCL2559Contig1 & At1g65720 & expressed protein & $1 \mathrm{E}-28$ \\
\hline aCL2555Contig1 & At2g44100 & Rab GDP dissociation inhibitor (GDI1) & 0 \\
\hline aCL2553Contig1 & At4g30930 & 50 S ribosomal protein L21 (RPL21M) & $8 \mathrm{E}-49$ \\
\hline aCL2546Contig1 & At3g63190 & ribosome recycling factor (RRF) & $3 E-84$ \\
\hline aCL2535Contig1 & At1g18740 & expressed protein & $1 \mathrm{E}-101$ \\
\hline aCL2511Contig1 & At2g02760 & ubiquitin-conjugating enzyme 2 (UBC2) & $1 \mathrm{E}-85$ \\
\hline aCL2501Contig1 & At4g33550 & protease inhibitor/seed storage/lipid transfer protein (LTP) & $2 \mathrm{E}-16$ \\
\hline aCL2500Contig2 & At1g75510 & transcription initiation factor IIF beta subunit (TFIIF-beta) & $6 \mathrm{E}-70$ \\
\hline aCL2500Contig1 & At1g75510 & transcription initiation factor IIF beta subunit (TFIIF-beta) & $4 \mathrm{E}-97$ \\
\hline aCL24Contig5 & At3g52590 & ubiquitin extension protein 1 (UBQ1) & $6 \mathrm{E}-69$ \\
\hline aCL248Contig2 & At5g06290 & 2-cys peroxiredoxin & $1 \mathrm{E}-102$ \\
\hline aCL248Contig1 & At5g06290 & 2-cys peroxiredoxin & $1 \mathrm{E}-106$ \\
\hline aCL2478Contig1 & At5g52650 & $40 S$ ribosomal protein S10 (RPS10C) & $1 \mathrm{E}-45$ \\
\hline aCL2471Contig1 & At5g34850 & calcineurin-like phosphoesterase family protein & 0 \\
\hline aCL2470Contig2 & At2g47710 & universal stress protein (USP) family protein & $1 \mathrm{E}-63$ \\
\hline aCL243Contig1 & At1g76020 & expressed protein & $6 \mathrm{E}-63$ \\
\hline aCL2434Contig2 & At3g25140 & glycosyl transferase family 8 protein & $1 \mathrm{E}-103$ \\
\hline aCL241Contig2 & At1g72520 & lipoxygenase & $7 \mathrm{E}-36$ \\
\hline aCL2419Contig1 & At5g08560 & transducin family protein / WD-40 repeat family protein & 0 \\
\hline aCL2410Contig1 & At4g11150 & vacuolar ATP synthase subunit E (VATE) & $3 E-88$ \\
\hline aCL2404Contig1 & At2g30050 & transducin family protein / WD-40 repeat family protein & $1 \mathrm{E}-153$ \\
\hline aCL2398Contig1 & At3g10950 & $60 S$ ribosomal protein L37a (RPL37aB) & $2 \mathrm{E}-46$ \\
\hline aCL2388Contig2 & At1g52230 & photosystem I reaction center subunit VI (PSI-H) & $2 \mathrm{E}-45$ \\
\hline aCL2386Contig2 & At4g31860 & protein phosphatase 2C (PP2C) & $1 \mathrm{E}-172$ \\
\hline aCL2385Contig1 & At3g06680 & 60S ribosomal protein L29 (RPL29B) & $3 E-25$ \\
\hline aCL2370Contig1 & At4g00870 & basic helix-loop-helix (bHLH) family protein & $2 \mathrm{E}-45$ \\
\hline aCL236Contig1 & At1g23440 & pyrrolidone-carboxylate peptidase family protein & $6 \mathrm{E}-92$ \\
\hline aCL2356Contig1 & At2g43750 & cysteine synthase & $1 \mathrm{E}-152$ \\
\hline aCL2352Contig1 & At1g07080 & GILT family protein & $1 \mathrm{E}-74$ \\
\hline aCL2336Contig1 & At2g20260 & photosystem I reaction center subunit IV (PSI-E) & $8 \mathrm{E}-25$ \\
\hline aCL232Contig1 & At5g48480 & expressed protein & $2 \mathrm{E}-18$ \\
\hline aCL2305Contig1 & At3g52560 & ubiquitin-conjugating enzyme family protein & $2 \mathrm{E}-75$ \\
\hline aCL2302Contig1 & At1g01220 & GHMP kinase-related & $1 \mathrm{E}-122$ \\
\hline aCL2291Contig1 & At4g38800 & phosphorylase family protein & $2 \mathrm{E}-94$ \\
\hline aCL2267Contig1 & At5g25754 & expressed protein & 0 \\
\hline aCL225Contig4 & At5g59910 & histone $\mathrm{H} 2 \mathrm{~B}$ & $3 E-45$ \\
\hline aCL225Contig1 & At2g27385 & expressed protein & $5 E-32$ \\
\hline aCL2247Contig1 & At1g15780 & expressed protein & $6 \mathrm{E}-28$ \\
\hline aCL2246Contig1 & At4g01590 & similar to expressed protein & $1 \mathrm{E}-16$ \\
\hline aCL2222Contig1 & At3g54360 & expressed protein & $1 \mathrm{E}-140$ \\
\hline aCL2219Contig1 & At4g02050 & sugar transporter & 0 \\
\hline aCL2218Contig2 & At5g42150 & expressed protein & $1 \mathrm{E}-77$ \\
\hline aCL2217Contig1 & At5g09420 & chloroplast outer membrane translocon subunit & $3 \mathrm{E}-82$ \\
\hline
\end{tabular}


aCL2213Contig1 aCL2203Contig2 aCL21Contig6 aCL2193Contig1 aCL2192Contig1 aCL218Contig2 aCL217Contig1 aCL2176Contig1 aCL2173Contig1 aCL2172Contig1 aCL2166Contig1 aCL2159Contig1 aCL2154Contig1 aCL2150Contig1 aCL2147Contig1 aCL2142Contig2 aCL2139Contig1 aCL2121Contig1 aCL211Contig1 aCL2101Contig1 aCL20Contig9 aCL20Contig5 aCL209Contig1 aCL2078Contig1 aCL2046Contig1 aCL2040Contig3 aCL2027Contig1 aCL200Contig1 aCL2005Contig1 aCL1Contig33 aCL1Contig22 aCL1Contig12 aCL199Contig1 aCL1999Contig2 aCL198Contig1 aCL1988Contig1 aCL1982Contig1 aCL197Contig1 aCL1963Contig1 aCL1948Contig1 aCL1940Contig1 aCL190Contig4 aCL190Contig1 aCL1903Contig1 aCL18Contig2 aCL18Contig1 aCL1890Contig1 aCL1887Contig1 aCL1869Contig1 aCL1861Contig1 aCL1806Contig1 aCL179Contig2 aCL1798Contig1 aCL1794Contig1 aCL1787Contig1 aCL1785Contig1 aCL177Contig1 aCL1778Contig1 aCL1769Contig1 aCL1765Contig2 aCL1764Contig1
At5g01820

At5g02020

At5g60390

At5g16050

At1g78870

At1g16300

At1g55490

At2g05790

At2g47970

At3g24590

At5g43330

At1g23400

At3g56340

At1g27340

At1g55915

At4g31130

At5g64510

At3g03420

At1g65930

At3g01680

At3g57240

At3g57240

At4g24280

At4g32760

At5g19780

At1g19180

At4g38580

At2g15430

At5g61030

At1g17860

At1g67360

At1g17860

At1g53280

At4g25630

At2g04240

At1g74050

At4g25130

At4g16190

At5g59850

At1g64350

At1g12410

At1g17860

At1g17860

At4g02620

At5g63910

At3g51030

At4g38600

At2g24360

At4g24210

At2g40100

At1g51060

At3g44110

At4g37890

At3g49250

At1g24510

At2g01660

At1g19000

At1g21750

At3g15000

At4g25650

At3g18080
CBL-interacting protein kinase 14 (CIPK14) expressed protein elongation factor 1-alpha (EF-1-alpha) 14-3-3 protein GF14 upsilon (GRF5) ubiquitin-conjugating enzyme glyceraldehyde 3-phosphate dehydrogenase RuBisCO subunit binding-protein beta subunit glycosyl hydrolase family 17 protein

NPL4 family protein

signal peptidase I family protein

malate dehydrogenase

expressed protein

40 S ribosomal protein S26 (RPS26C)

F-box family protein

expressed protein

expressed protein

expressed protein

Ku70-binding family protein

isocitrate dehydrogenase

expressed protein

similar to glycosyl hydrolase family 17 protein

similar to glycosyl hydrolase family 17 protein

heat shock protein 70 (HSP70)

similar to VHS domain-containing protein

tubulin alpha-3/alpha-5 chain (TUA5)

expressed protein

copper chaperone $(\mathrm{CCH})$-related

RNA polymerase II subunit 3 (RPB36A)

RNA-binding protein

trypsin and protease inhibitor family protein

rubber elongation factor (REF) family protein

trypsin and protease inhibitor family protein

DJ-1 family protein

fibrillarin 2 (FIB2)

zinc finger (C3HC4-type RING finger) family protein

60 S ribosomal protein L6 (RPL6C)

peptide methionine sulfoxide reductase

cysteine proteinase

40 S ribosomal protein S15A (RPS15aF)

transducin family protein / WD-40 repeat family protein

ATP-dependent Clp protease proteolytic subunit (ClpP2)

trypsin and protease inhibitor family protein

trypsin and protease inhibitor family protein

vacuolar ATPase subunit $F$ family protein

expressed protein

thioredoxin $\mathrm{H}$-type 1 (TRX-H-1)

HECT-domain-containing protein

serine/threonine/tyrosine kinase

F-box family protein / SLEEPY1 protein

chlorophyll A-B binding protein (LHCB4.3)

histone $\mathrm{H} 2 \mathrm{~A}$

DNAJ heat shock protein $(\mathrm{J} 3)$

zinc finger (C3HC4-type RING finger) family protein

expressed protein

T-complex protein 1 epsilon subunit (TCP-1-epsilon)

$33 \mathrm{kDa}$ secretory protein-related

myb family transcription factor

encodes a protein disulfide isomerase-like (PDIL) protein

$1 \mathrm{E}-120$

9E-08

$1 \mathrm{E}-129$

$1 \mathrm{E}-127$

$4 \mathrm{E}-84$

$1 \mathrm{E}-133$

$$
0
$$

0

$1 \mathrm{E}-114$

$4 \mathrm{E}-73$

$1 \mathrm{E}-166$

$3 \mathrm{E}-98$

$1 \mathrm{E}-30$

$1 \mathrm{E}-180$

$9 \mathrm{E}-86$

3E-62

$6 \mathrm{E}-88$

$4 \mathrm{E}-82$

1E-56

$1 \mathrm{E}-107$

$1 \mathrm{E}-114$

1E-155

2E-26

$5 \mathrm{E}-66$

$1 \mathrm{E}-150$

2E-43

$3 \mathrm{E}-26$

$5 \mathrm{E}-60$

$7 \mathrm{E}-24$

5E-79

1E-127

4E-44

1E-84

7E-99

$1 \mathrm{E}-158$

2E-69

$1 \mathrm{E}-131$

$1 \mathrm{E}-118$

$4 \mathrm{E}-26$

$1 \mathrm{E}-26$

4E-51

2E-24

8E-42

$1 \mathrm{E}-176$

5E-40

$1 \mathrm{E}-114$

$6 \mathrm{E}-44$

1E-168

$1 \mathrm{E}-158$

1E-91

$1 \mathrm{E}-126$

3E-79

7E-49

expressed protein

Rieske (2Fe-2S) domain-containing protein

glycosyl hydrolase family 1 protein
0

2E-72

$1 \mathrm{E}-101$ 
aCL175Contig1 aCL1758Contig1 aCL1755Contig1 aCL1753Contig1 aCL1749Contig1 aCL1737Contig1 aCL172Contig2 aCL16Contig2 aCL16Contig1 aCL1683Contig2 aCL1678Contig2 aCL1671Contig1 aCL1661Contig2 aCL165Contig1 aCL1648Contig2 aCL163Contig1 aCL1636Contig1 aCL1635Contig2 aCL161Contig1 aCL1615Contig1 aCL1613Contig1 aCL1606Contig2 aCL15Contig4 aCL1588Contig1 aCL157Contig1 aCL1577Contig1 aCL156Contig1 aCL1524Contig1 aCL1512Contig1 aCL150Contig1 aCL1507Contig2 aCL14Contig2 aCL1498Contig1 aCL148Contig1 aCL1483Contig2 aCL147Contig1 aCL1478Contig1 aCL1466Contig2 aCL1438Contig1 aCL1432Contig1 aCL142Contig1 aCL1426Contig1 aCL1421Contig1 aCL1405Contig1 aCL1402Contig1 aCL13Contig7 aCL1396Contig1 aCL1386Contig2 aCL1370Contig3 aCL1370Contig2 aCL136Contig1 aCL1354Contig1 aCL1352Contig1 aCL134Contig1 aCL1340Contig1 aCL133Contig3 aCL1337Contig3 aCL132Contig2 aCL1326Contig1 aCL131Contig5 aCL1319Contig1
At4g29040

At5g23240

At1g78700

At1g65820

At5g13550

At4g01070

At5g25610

At3g12490

At5g54770

At4g31940

At5g66380

At5g18400

At4g17510

At5g60660

At1g03900

At4g18100

At1g68010

At4g13010

At4g31750

At4g01000

At3g18490

At3g43190

At2g29630

At2g45770

At2g35940

At2g35940

At1g14720

At5g17310

At1g02130

At3g22440

At2g29420

At5g51100

At3g14420

At1g79040

At5g47830

At2g37110

At1g60000

At1g05850

At3g13160

At1g62040

At2g33040

At1g29260

At4g20360

At3g54810

At5g08260

At3g43810

At5g13520

At5g66650

At1g32470

At3g24503

At3g48750

At1g73760

At4g35110

At2g45550

At4g03280

AtMg00030

At4g38620

At1g19180

At4g36910

At5g58240

At1g32060
26S proteasome AAA-ATPase subunit (RPT2a)

DNAJ heat shock $\mathrm{N}$-terminal domain-containing protein

$1 \mathrm{E}-127$ brassinosteroid signalling positive regulator-related

$6 \mathrm{E}-71$

2E-65 microsomal glutathione s-transferase

sulfate transporter family protein

glycosyltransferase (UGT72B1)

dehydration-responsive protein (RD22)

$1 \mathrm{E}-116$

$1 \mathrm{E}-162$

$4 \mathrm{E}-93$

$4 \mathrm{E}-25$

similar to cysteine protease inhibitor

thiazole biosynthetic enzyme (ARA6) (THI1) (THI4)

$1 \mathrm{E}-151$

cytochrome P450

encodes a folate transporter

expressed protein

7E-67

$1 \mathrm{E}-129$

2E-36

$1 \mathrm{E}-80$

ubiquitin carboxyl-terminal hydrolase

major intrinsic family protein / MIP family protein

expressed protein

$60 S$ ribosomal protein L32 (RPL32A)

glycerate dehydrogenase

oxidoreductase, zinc-binding dehydrogenase family protein

protein phosphatase $2 \mathrm{C}$ (PP2C)

ubiquitin family protein

aspartyl protease family protein

sucrose synthase

thiamine biosynthesis family protein

signal recognition particle receptor protein (FTSY)

similar to BEL1-like homeobox 4 protein (BLH4)

similar to BEL1-like homeobox 4 protein (BLH4)

xyloglucan:xyloglucosyl transferase (XTR2)

UTP--glucose-1-phosphate uridylyltransferase

Ras-related protein (ARA-5) / small GTP-binding protein

hydroxyproline-rich glycoprotein family protein

glutathione S-transferase

superoxide dismutase $(\mathrm{Fe})$

(S)-2-hydroxy-acid oxidase / glycolate oxidase (GOX)

photosystem II $10 \mathrm{kDa}$ polypeptide (PsbR)

expressed protein

expressed protein

$29 \mathrm{kDa}$ ribonucleoprotein

chitinase-like protein 1 (CTL1)

pentatricopeptide (PPR) repeat-containing protein

autophagy 8c (APG8c)

ATP synthase gamma chain (ATPC)

peroxisomal targeting signal type 2 receptor (PEX7)

elongation factor Tu / EF-Tu (TUFA)

$1 \mathrm{E}-130$

$1 \mathrm{E}-87$

$5 \mathrm{E}-57$

3E-67

$1 \mathrm{E}-150$

3E-60

$1 \mathrm{E}-162$

1E-96

1E-176

$1 \mathrm{E}-164$

9E-09

5E-29

$1 \mathrm{E}-129$

0

1E-102

$1 \mathrm{E}-180$

8E-50

2E-81

$1 \mathrm{E}-177$

2E-47

9E-40

4E-94

2E-67

$1 \mathrm{E}-142$

1E-79

6E-58

$1 \mathrm{E}-147$

1E-168

zinc finger (GATA type) family protein

2E-67

$1 \mathrm{E}-102$

3E-81

$1 \mathrm{E}-159$

$1 \mathrm{E}-37$

$4 \mathrm{E}-71$

2E-21

$1 \mathrm{E}-147$

7E-39

2E-64

$1 \mathrm{E}-133$

2E-96

$2 \mathrm{E}-22$

$2 \mathrm{E}-73$

$5 \mathrm{E}-39$

$4 \mathrm{E}-75$

\begin{tabular}{lr} 
bis(5'-adenosyl)-triphosphatase & $2 \mathrm{E}-67$ \\
\hline
\end{tabular} 
aCL1317Contig1 aCL1313Contig1 aCL130Contig5 aCL130Contig1 aCL12Contig9 aCL128Contig3 aCL1285Contig3 aCL1283Contig1 aCL1280Contig1 aCL1274Contig1 aCL1270Contig1 aCL126Contig1 aCL125Contig1 aCL1259Contig2 aCL1240Contig1 aCL123Contig1 aCL1233Contig1 aCL1232Contig1 aCL1231Contig2 aCL1205Contig1 aCL1202Contig2 aCL1199Contig2 aCL1174Contig1 aCL1164Contig1 aCL115Contig1 aCL1153Contig2 aCL1153Contig1 aCL112Contig4 aCL112Contig3 aCL1122Contig1 aCL1112Contig2 aCL1107Contig2 aCL1106Contig1 aCL1104Contig1 aCL10Contig9 aCL10Contig4 aCL1097Contig1 aCL1095Contig1 aCL1091Contig1 aCL1070Contig1 aCL1066Contig1 aCL1062Contig1 aCL1023Contig1 aCL1011Contig2 aCL1002Contig1 $\mathrm{aC} 0102 \mathrm{OH} 11$ $\mathrm{aC} 0102 \mathrm{OH} 02$ aC01020H01 aC01020G12 aC01020G10 aC01020G06 aC01020G04 aC01020E12 aC01020E11 aC01020E09 aC01020D05 aC01020D02 aC01020D01 aC01020C07 aC01020C04 aC01020C02
At1g65980 At5g41685 At5g40370 At1g26550 At3g18280 At5g22000 At1g07350 At2g29570 At3g21175 At5g45775 At2g28910 At5g59950 At2g37220 At3g59540 At5g67420 At5g54160 At2g16500 At3g15360 At2g24260 At1g32230 At4g15940 At5g17380 At5g14780 At1g56340 At3g03070 At4g26840 At4g26840 At3g04880 At3g04880 At1g24120 At2g47770 At5g13450 At3g51370 At1g70160 At3g12500 At3g12500 At4g38220 At3g52580 At3g52300 At4g02080 At4g35220 At5g09590 At5g13930 At2g39450 At5g33340 At5g25780 At2g32400 At4g31050 At1g50180 At2g29650 At2g47620 At2g38650 At5g38350 At5g64480 At2g16650 At1g09240 At1g11260 At2g29260 At5g40950 AtCg00540 At5g45530 peroxiredoxin type 2

mitochondrial import receptor subunit TOM7

9E-75 glutaredoxin peptidyl-prolyl cis-trans isomerase PPIC-type family protein protease inhibitor/seed storage/lipid transfer protein (LTP) zinc finger (C3HC4-type RING finger) family protein transformer serine/arginine-rich ribonucleoprotein proliferating cell nuclear antigen 2 (PCNA2) zinc finger (GATA type) family protein 60S ribosomal protein L11 (RPL11D) CAX-interacting protein 4 (CAXIP4) RNA and export factor-binding protein $29 \mathrm{kDa}$ ribonucleoprotein 60S ribosomal protein L38 (RPL38B) LOB domain protein 37 (LBD37) quercetin 3-O-methyltransferase 1 (OMT1) arginine decarboxylase 1 (SPE1) thioredoxin M-type 4 (TRX-M4) basic helix-loop-helix (bHLH) family protein WWE domain-containing protein (CEO) fumarylacetoacetate hydrolase family protein pyruvate decarboxylase family protein formate dehydrogenase (FDH) calreticulin 1 (CRT1) $\mathrm{NADH}$-ubiquinone oxidoreductase-related ubiquitin-like protein (SMT3) ubiquitin-like protein (SMT3)

DNA-damage-repair/toleration protein (DRT102) DNA-damage-repair/toleration protein (DRT102)

DNAJ heat shock protein benzodiazepine receptor-related (PBR)

ATP synthase delta chain

$1 \mathrm{E}-22$

$6 \mathrm{E}-42$

$2 \mathrm{E}-57$

$2 \mathrm{E}-23$

$1 \mathrm{E}-107$

2E-36

$1 \mathrm{E}-135$

$5 \mathrm{E}-57$

3E-85

$1 \mathrm{E}-48$

7E-61

3E-77

2E-32

1E-73

6E-52

$1 \mathrm{E}-137$

1E-48

3E-57

2E-52

$2 \mathrm{E}-59$

1E-180

$1 \mathrm{E}-173$

5E-42

$5 \mathrm{E}-43$

6E-43

$1 \mathrm{E}-123$

$1 \mathrm{E}-115$

$1 \mathrm{E}-114$

3E-41

3E-53 protein phosphatase 2C (PP2C) 1E-176 expressed protein

basic endochitinase

$6 \mathrm{E}-76$

$3 \mathrm{E}-82$

$5 \mathrm{E}-87$ aminoacylase 1E-141

40S ribosomal protein S14 (RPS14C) 3E-61

ATP synthase D chain-related $\quad 8 \mathrm{E}-73$

GTP-binding protein (SAR1A) 2E-85

cyclase family protein 4E-99

heat shock protein 70 (HSP70)

chalcone synthase / naringenin-chalcone synthase $\quad 1 \mathrm{E}-112$

cation efflux family protein

aspartyl protease family protein

1E-110

2E-84

7E-97

1E-76

1E-51

4E-09

2E-37

1E-07

9E-37

5E-38

$1 \mathrm{E}-26$

5E-91

7E-74

1E-20

5E-69

3E-32

$4 \mathrm{E}-50$

$1 \mathrm{E}-08$ 


\begin{tabular}{|c|c|c|c|}
\hline aC01020B11 & At2g29420 & glutathione S-transferase & $1 \mathrm{E}-42$ \\
\hline aC01020B06 & At3g10630 & glycosyl transferase family 4 protein & $4 \mathrm{E}-85$ \\
\hline aC01020B05 & At1g75690 & chaperone protein dnaJ-related & $8 \mathrm{E}-25$ \\
\hline aC01020B01 & At4g13140 & expressed protein & $2 \mathrm{E}-46$ \\
\hline aC01020A01 & At1g79610 & sodium proton exchanger ( $\mathrm{NHX6)}$ & $3 E-21$ \\
\hline aC01019H05 & At3g25410 & bile acid:sodium symporter family protein & $1 \mathrm{E}-37$ \\
\hline aC01019G10 & At3g19900 & expressed protein & $4 \mathrm{E}-39$ \\
\hline aC01019G09 & At1g52140 & expressed protein & $1 \mathrm{E}-32$ \\
\hline aC01019F06 & At4g25340 & FKBP-type peptidyl-prolyl cis-trans isomerase-related & $6 \mathrm{E}-27$ \\
\hline aC01019F05 & At3g48470 & expressed protein & $1 \mathrm{E}-34$ \\
\hline aC01019F02 & At4g28290 & expressed protein & 4E-08 \\
\hline aC01019E12 & At2g30580 & zinc finger (C3HC4-type RING finger) family protein & $1 \mathrm{E}-38$ \\
\hline aC01019E06 & At4g19006 & $26 S$ proteasome regulatory subunit (RPN9) & $2 \mathrm{E}-97$ \\
\hline aC01019E05 & At3g27930 & expressed protein & $8 \mathrm{E}-63$ \\
\hline aC01019E01 & At5g42090 & expressed protein & $6 \mathrm{E}-31$ \\
\hline aC01019D09 & At4g36920 & floral homeotic protein APETALA2 (AP2) & $2 \mathrm{E}-58$ \\
\hline aC01019D07 & At1g24020 & Bet v I allergen family protein & 2E-09 \\
\hline aC01019D04 & At3g25950 & expressed protein & $1 \mathrm{E}-69$ \\
\hline aC01019D02 & At5g58005 & expressed protein & $6 \mathrm{E}-27$ \\
\hline aC01019A05 & At4g30810 & serine carboxypeptidase $\mathrm{S} 10$ family protein & 7E-34 \\
\hline aC01018H10 & At1g18070 & similar to elongation factor 1-alpha (EF-1-alpha) & $8 \mathrm{E}-20$ \\
\hline aC01018H07 & At1g56050 & GTP-binding protein-related & 3E-79 \\
\hline $\mathrm{aC} 01018 \mathrm{H} 01$ & At1g50200 & aminoacyl-tRNA synthetase family protein & $5 E-46$ \\
\hline aC01018G11 & At4g08850 & leucine-rich repeat family protein & $6 \mathrm{E}-16$ \\
\hline aC01018G09 & At2g21940 & shikimate kinase & $3 E-37$ \\
\hline aC01018F10 & At2g47710 & universal stress protein (USP) family protein & $2 \mathrm{E}-16$ \\
\hline aC01018F09 & At2g33150 & acetyl-CoA C-acyltransferase & $7 \mathrm{E}-65$ \\
\hline aC01018E04 & At3g51290 & proline-rich family protein & $2 \mathrm{E}-26$ \\
\hline aC01018E03 & At4g16320 & expressed protein & $5 E-29$ \\
\hline aC01018E02 & At3g27050 & expressed protein & $4 \mathrm{E}-53$ \\
\hline aC01018D10 & At5g37970 & S-adenosyl-L-methionine:carboxyl methyltransferase & $1 \mathrm{E}-52$ \\
\hline aC01018D08 & At4g20060 & expressed protein & $2 \mathrm{E}-21$ \\
\hline aC01018D06 & At3g54420 & class IV chitinase (CHIV) & $2 \mathrm{E}-37$ \\
\hline aC01018D04 & At5g40550 & expressed protein & $2 \mathrm{E}-69$ \\
\hline aC01018D02 & At2g23840 & $\mathrm{HNH}$ endonuclease domain-containing protein & $3 E-59$ \\
\hline aC01018C12 & At3g53950 & glyoxal oxidase-related & $1 \mathrm{E}-51$ \\
\hline aC01018C10 & At5g43130 & similar to transcription initiation factor IID (TFIID) & 7E-50 \\
\hline aC01018C09 & At5g27320 & expressed protein & $3 E-54$ \\
\hline aC01018C06 & At5g06160 & splicing factor-related & $1 \mathrm{E}-50$ \\
\hline aC01018C01 & At3g57510 & endo-polygalacturonase (ADPG1) & $2 \mathrm{E}-28$ \\
\hline aC01018B12 & At1g01950 & armadillo/beta-catenin repeat family protein & $1 \mathrm{E}-16$ \\
\hline aC01018A07 & At2g29440 & glutathione S-transferase & $8 \mathrm{E}-32$ \\
\hline aC01018A06 & At4g35160 & O-methyltransferase family 2 protein & $1 \mathrm{E}-33$ \\
\hline aC01018A04 & At1g08380 & expressed protein & $9 \mathrm{E}-14$ \\
\hline aC01018A01 & At5g40440 & mitogen-activated protein kinase kinase (MAPKK) & $8 \mathrm{E}-66$ \\
\hline aC01017H01 & At4g23730 & aldose 1-epimerase family protein & $3 E-35$ \\
\hline aC01017G07 & At1g05690 & TAZ zinc finger family protein & 4E-09 \\
\hline aC01017F11 & At5g04590 & sulfite reductase / ferredoxin (SIR) & $3 E-55$ \\
\hline aC01017F06 & At1g72770 & protein phosphatase $2 \mathrm{C}(\mathrm{P} 2 \mathrm{C}-\mathrm{HA})$ & $4 \mathrm{E}-41$ \\
\hline aC01017E08 & At5g25590 & expressed protein & $4 \mathrm{E}-22$ \\
\hline aC01017E02 & At1g05000 & tyrosine specific protein phosphatase family protein & $6 \mathrm{E}-79$ \\
\hline aC01017D08 & At3g23910 & expressed protein & $4 \mathrm{E}-69$ \\
\hline aC01017D06 & At2g37035 & expressed protein & $5 E-13$ \\
\hline aC01017C08 & At1g30740 & FAD-binding domain-containing protein & $4 \mathrm{E}-29$ \\
\hline aC01017C05 & At3g01070 & plastocyanin-like domain-containing protein & $8 \mathrm{E}-25$ \\
\hline aC01017B12 & At1g60690 & aldo/keto reductase family protein & $4 \mathrm{E}-78$ \\
\hline aC01017A08 & At5g23960 & encodes a sesquiterpene synthase & $1 \mathrm{E}-30$ \\
\hline aC01017A05 & At4g12290 & copper amine oxidase & $1 \mathrm{E}-113$ \\
\hline $\mathrm{aC} 01016 \mathrm{H} 07$ & At3g28345 & ABC transporter family protein & $4 \mathrm{E}-48$ \\
\hline aC01016G11 & At3g43740 & leucine-rich repeat family protein & $7 \mathrm{E}-30$ \\
\hline aC01016G08 & At3g61320 & expressed protein & $8 \mathrm{E}-17$ \\
\hline
\end{tabular}


aC01016G07

aC01016G03

aC01016G01

aC01016F12

aC01016F10

aC01016E04

aC01016E03

aC01016D10

aC01016D06

aC01016C07

aC01016C03

aC01016B08

aC01016B03

aC01016A01

aC01015H12

aC01015H08

aC01015G12

aC01015G07

aC01015G06

aC01015G04

aC01015F12

aC01015F02

aC01015E12

aC01015E01

aC01015D10

aC01015D03

aC01015D01

aC01015C10

aC01015C04

aC01015B09

aC01015A09

aC01014F11

aC01014E07

aC01014D09

aC01014D06

aC01014C06

aC01014B12

aC01014B10

aC01014B02

aC01014A11

aC01014A07

aC01014A05

aC01014A03

aC01013H11

aC01013H02

aC01013F12

aC01013F11

aC01013E12

aC01013E11

aC01013E07

aC01013E02

aC01013D07

aC01013D05

aC01013C06

aC01013C02

aC01013B08

aC01013B02

aC01013A09

aC01013A07

aC01013A04

$\mathrm{aC} 01012 \mathrm{H} 10$
At1g15340

At1g78915

At3g43810

At2g38330

At2g22780

At5g35750

At1g15990

At3g26000

At3g50950

At4g29060

At3g27820

At5g24530

At1g75220

At2g45990

At5g27280

At3g24730

At5g55260

At5g03455

At3g19960

At5g22320

At3g04790

At3g10620

At1g45130

At2g34790

At4g28780

At2g26150

At1g06620

At3g21820

At5g58240

At1g26520

At3g09050

At1g11410

At2g02240

At3g58610

At3g53180

At2g15690

At4g13030

At1g76860

At3g06330

At5g20060

At2g41900

At1g61030

At1g69523

At4g10000

At5g49220

At1g32080

At1g70780

At1g51760

At1g10910

At5g46630

At1g54710

At1g42540

At5g60620

At5g27430

At3g49010

At5g63050

At1g08190

At5g07020

At2g40320

At4g33220

At3g57030
methyl-CpG-binding domain-containing protein

expressed protein

calmodulin-7 (CAM7)

MATE efflux family protein

malate dehydrogenase (PMDH1)

histidine kinase (AHK2)

cyclic nucleotide-regulated ion channel (CNGC7)

F-box family protein

disease resistance protein (CC-NBS-LRR class)

elongation factor Ts family protein (EF-Ts)

monodehydroascorbate reductase

oxidoreductase, 2OG-Fe(II) oxygenase family protein

integral membrane protein

expressed protein

zinc finger (DNL type) family protein

similar to yellow-leaf-specific protein 8 (YLS8)

serine/threonine protein phosphatase PP-X isozyme 2

rhodanese-like domain-containing protein

myosin (ATM)

leucine-rich repeat family protein

ribose 5-phosphate isomerase-related

diadenosine 5',5"'-P1,P4-tetraphosphate hydrolase

beta-galactosidase

FAD-binding domain-containing protein

GDSL-motif lipase/hydrolase family protein

heat shock transcription factor family protein

2-oxoglutarate-dependent dioxygenase

SET domain-containing protein

bis(5'-adenosyl)-triphosphatase

similar to PRLI-interacting factor $\mathrm{L}$

expressed protein

S-locus protein kinase

F-box family protein / SKP1 interacting partner 3-related

ketol-acid reductoisomerase

glutamine synthetase

pentatricopeptide (PPR) repeat-containing protein

expressed protein

small nuclear ribonucleoprotein

zinc finger (C3HC4-type RING finger) family protein

similar to phospholipase/carboxylesterase family protein

zinc finger ( $\mathrm{CCCH}$-type) family protein

expressed protein

UbiE/COQ5 methyltransferase family protein

expressed protein

expressed protein

membrane protein, contains 12 transmembrane domains

expressed protein

IAA-amino acid hydrolase 3 (IAR3)

pentatricopeptide (PPR) repeat-containing protein

clathrin adaptor complexes medium subunit family protein

expressed protein

glutamate receptor family protein (GLR3.3)

phospholipid/glycerol acyltransferase family protein

signal peptidase subunit family protein

similar to 60S ribosomal protein L13 (RPL13D)

expressed protein

vacuolar assembly protein (VPS41)

proline-rich family protein

expressed protein

pectinesterase family protein

strictosidine synthase family protein
$1 \mathrm{E}-35$

$3 \mathrm{E}-40$

$1 \mathrm{E}-51$

$3 \mathrm{E}-73$

$5 \mathrm{E}-89$

$1 \mathrm{E}-117$

2E-37

2E-77

2E-77

4E-58

1E-18

2E-52

7E-86

2E-81

2E-63

9E-55

$1 \mathrm{E}-112$

2E-56

$3 \mathrm{E}-31$

3E-83

$6 \mathrm{E}-61$

1E-81

8E-98

4E-75

1E-56

$6 \mathrm{E}-38$

2E-68

$1 \mathrm{E}-46$

1E-23

8E-57

9E-66

$7 \mathrm{E}-16$

1E-21

4E-40

5E-53

2E-38

2E-35

1E-07

8E-33

2E-24

1E-54

3E-12

2E-56

3E-16

$6 \mathrm{E}-40$

$6 \mathrm{E}-81$

8E-20

2E-57

5E-18

9E-69

$7 \mathrm{E}-14$

1E-49

3E-38

4E-44

3E-19

2E-06

$6 \mathrm{E}-43$

5E-33

1E-57

6E-06

3E-42 
aC01012H05 aC01012H01 aC01012G08 aC01012G05 aC01012G03 aC01012F08 aC01012E09 aC01012E03 aC01012D02 aC01012C05 aC01012C02 aC01012B07 aC01012B04 aC01012B02 aC01012A04 aC01011H10 aC01011H03 aC01011F03 aC01011E07 aC01011E04 aC01011D09 aC01011D07 aC01011D06 aC01011C12 aC01011C01 aC01011B05 aC01011A09 aC01011A07 aC01011A02 aC01010H09 aC01010H06 aC01010H05 aC01010H03 aC01010G11 aC01010F01 aC01010D12 aC01010D10 aC01010D06 aC01010D02 aC01010C12 aC01010C05 aC01010B09 aC01010A07 aC01010A01 aC01009H02 aC01009G11 aC01009G08 aC01009G02 aC01009F11 aC01009F07 aC01009F05 aC01009E09 aC01009E04 aC01009D06 aC01009C05 aC01009C02 aC01009B02 aC01009A12 aC01009A05 aC01009A02 $\mathrm{aC} 01008 \mathrm{H} 08$
At5g17790

At3g02350

At4g31240

At5g27270

At3g18870

At1g42470

At1g20925

At5g35080

At4g28088

At1g49210

At5g66150

At1g04770

At3g10550

At5g16990

At5g36930

At4g39460

At3g01410

At5g16010

At3g02020

At5g58300

At1g77740

At3g14080

At1g69780

At1g47890

At5g13070

At2g32230

At2g46220

At1g78020

At3g57330

At1g21065

At2g30710

At5g51970

At1g09290

At3g12380

At3g03570

At4g16390

At5g63860

At5g06240

At2g32580

At5g10250

At2g41520

At5g09300

At5g06800

At4g26600

At1g64720

At5g48790

At4g01650

At1g76080

At5g10140

At2g05120

At5g40980

At1g32080

AtCg00120

At1g76730

At3g28050

At5g04550

At5g40720

At4g15215

At2g39210

At5g59030

At4g28830 zinc finger (Ran-binding) family protein

glycosyl transferase family 8 protein

$5 \mathrm{E}-15$

$4 \mathrm{E}-19$

expressed protein

pentatricopeptide (PPR) repeat-containing protein

$1 \mathrm{E}-30$

$5 \mathrm{E}-24$

$1 \mathrm{E}-20$

mitochondrial transcription termination factor-related

$2 \mathrm{E}-44$

auxin efflux carrier family protein $\quad 5 \mathrm{E}-43$

expressed protein

hydrophobic protein

$1 \mathrm{E}-54$

$4 \mathrm{E}-23$

zinc finger (C3HC4-type RING finger) family protein 1E-51

glycosyl hydrolase family 38 protein $3 \mathrm{E}-18$

male sterility MS5 family protein $3 \mathrm{E}-59$

expressed protein $8 \mathrm{E}-32$

NADP-dependent oxidoreductase 2E-19

disease resistance protein (TIR-NBS-LRR class) 4E-31

mitochondrial substrate carrier family protein $3 \mathrm{E}-62$

RNase $\mathrm{H}$ domain-containing protein $1 \mathrm{E}-33$

3-oxo-5-alpha-steroid 4-dehydrogenase family protein 7E-41

aspartate kinase $\quad 8 \mathrm{E}-55$

leucine-rich repeat transmembrane protein kinase 1E-61

1-phosphatidylinositol-4-phosphate 5-kinase 2E-64

small nuclear ribonucleoprotein 3E-39

homeobox-leucine zipper protein 13 (HB-13) 1E-58

disease resistance family protein $2 \mathrm{E}-43$

MSF1-like family protein $8 \mathrm{E}-90$

pentatricopeptide (PPR) repeat-containing protein 3E-18

expressed protein $4 \mathrm{E}-35$

senescence-associated protein-related (SAG102) 1E-28

calcium-transporting ATPase 4E-07

expressed protein $1 \mathrm{E}-33$

RabGAP/TBC domain-containing protein 7E-14

sorbitol dehydrogenase 2E-34

expressed protein $3 E-21$

similar to actin $\quad 6 \mathrm{E}-36$

expressed protein 2E-65

chloroplastic RNA-binding protein P67 6E-52

UVB-resistance protein (UVR8) 2E-10

expressed protein $1 \mathrm{E}-29$

expressed protein $5 \mathrm{E}-33$

phototropic-responsive protein (RPT2) 7E-51

DNAJ heat shock N-terminal domain-containing protein $5 \mathrm{E}-52$

2-oxoisovalerate dehydrogenase 3E-44

myb family transcription factor $\quad 1 \mathrm{E}-28$

nucleolar protein $1 \mathrm{E}-61$

expressed protein 4E-43

expressed protein $\quad 8 \mathrm{E}-56$

expressed protein 2E-34

thioredoxin family protein (TRX) $8 \mathrm{E}-20$

MADS-box protein flowering locus F (FLF) 4E-22

expressed protein $\quad 5 \mathrm{E}-27$

expressed protein 2E-29

membrane protein, contains 12 transmembrane domains 1E-103

ATPase alpha subunit $\quad 9 \mathrm{E}-83$

5-formyltetrahydrofolate cyclo-ligase family protein $\quad 1 \mathrm{E}-47$

nodulin MtN21 family protein $8 \mathrm{E}-10$

expressed protein 3E-43

expressed protein 3E-33

$\mathrm{ABC}$ transporter family protein $3 \mathrm{E}-41$

nodulin family protein $\quad 1 \mathrm{E}-18$

copper transporter 1 (COPT1) 7E-28

expressed protein $\quad 5 \mathrm{E}-16$ 
aC01008H04 aC01008G12 aC01008G09 aC01008G04 aC01008E03 aC01008D08 aC01008C04 aC01008B12 aC01008B07 aC01006H06 aC01006G12 aC01006F11 aC01006E11 aC01006E05 aC01006D04 aC01006C12 aC01006C11 aC01006B09 aC01006A07 aC01006A06 aC01005H09 aC01005F02 aC01005F01 aC01005E06 aC01005E02 aC01005D04 aC01005C10 aC01005C08 aC01005C07 aC01005C06 aC01005B03 aC01005A10 aC01005A05 aC01004H07 aC01004D12 aC01004D07 aC01004C10 aC01004B07 aC01003H08 aC01003G12 aC01003G01 aC01003D11 aC01003D04 aC01003C11 aC01003C04 aC01003B10 aC01003B09 aC01003B08 aC01003B03 aC01003A09 aC01002H07 aC01002E01 aC01002D07 aC01002A08 aC01001H01 aC01001F11 aC01001F06 aC01001E11 aC01001C09 aC01001B11
At3g45040

At3g24800

At4g27700

At2g19440

At3g48590

At4g14570

At5g16780

At5g20110

At4g37580

At2g32450

At3g53940

At5g03940

At1g29800

At1g55860

At3g48770

At2g41190

At1g63910

At3g55050

At5g52030

At4g02630

At3g62000

At2g44920

At4g02075

At2g27960

At1g52190

At2g27150

At1g77800

At2g29140

At4g12420

At5g67370

At4g39250

At2g26830

At4g19400

At5g38660

At1g42540

At5g15450

At1g29000

At1g70320

At3g02330

At3g61200

At5g20280

At5g52780

At2g46820

At1g08920

At3g11340

At4g02510

At5g20660

At3g11210

At5g42950

At5g55300

At1g49180

At3g18030

At4g11860

At5g58930

At5g02810

At2g03780

At5g17910

At4g35980

At5g51350

At5g59610 phosphatidate cytidylyltransferase family protein

PRT1 protein (PRT1)

rhodanese-like domain-containing protein

glycosyl hydrolase family 17 protein

CCAAT-box binding transcription factor Hap5a

acylaminoacyl-peptidase-related

SART-1 family protein

dynein light chain

$\mathrm{N}$-acetyltransferase / hookless1 (HLS1)

calcium-binding EF hand family protein

mitochondrial substrate carrier family protein

signal recognition particle $54 \mathrm{kDa}$ protein (SRP54)

similar to zinc finger (FYVE type) family protein

ubiquitin-protein ligase 1 (UPL1)

expressed protein

amino acid transporter family protein

myb family transcription factor (MYB103)

serine/threonine protein phosphatase 2C (PP2C6)

TraB protein-related

protein kinase family protein

O-methyltransferase family 3 protein

thylakoid lumenal $15 \mathrm{kDa}$ protein

zinc finger (C3HC4-type RING finger) family protein

cyclin-dependent kinase (CKS1)

proton-dependent oligopeptide transport (POT) family protein $\quad 4 \mathrm{E}-78$

aldehyde oxidase 3 (AAO3)

PHD finger family protein

pumilio/Puf RNA-binding domain-containing protein 9E-36

multi-copper oxidase (SKU5)

expressed protein

myb family transcription factor

choline/ethanolamine kinase family protein

expressed protein

expressed protein

glutamate receptor family protein (GLR3.3)

heat shock protein 100 (HSP100)

heavy-metal-associated domain-containing protein

ubiquitin-protein ligase 2 (UPL2)

pentatricopeptide (PPR) repeat-containing protein

thioesterase family protein

sucrose-phosphate synthase

expressed protein

expressed protein

sugar transporter / similar to ERD6 protein

UDP-glucoronosyl/UDP-glucosyl transferase family protein

chloroplast outer membrane protein

$2 \mathrm{E}-06$

$2 \mathrm{E}-32$

$2 \mathrm{E}-14$

2E-65

$2 \mathrm{E}-56$

$4 \mathrm{E}-55$

$7 \mathrm{E}-23$

$5 \mathrm{E}-45$

$8 \mathrm{E}-36$

$1 \mathrm{E}-104$

$7 \mathrm{E}-25$

$3 \mathrm{E}-21$

$8 \mathrm{E}-88$

3E-69

1E-52

5E-32

9E-70

$6 \mathrm{E}-15$

1E-20

1E-16

2E-79

9E-26

$6 \mathrm{E}-44$

4E-51

4E-44

$2 \mathrm{E}-06$

1E-70

1E-06

$6 \mathrm{E}-74$

4E-42

$8 \mathrm{E}-18$

1E-68

8E-73

2E-12

2E-20

$1 \mathrm{E}-31$

3E-08

$6 \mathrm{E}-53$

3E-18

$5 \mathrm{E}-16$

3E-24

2E-51

1E-53

$24 \mathrm{kDa}$ vacuolar protein (VP24)

$2 \mathrm{E}-54$

GDSL-motif lipase/hydrolase family protein $\quad 1 \mathrm{E}-24$

GYF domain-containing protein 2E-28

DNA topoisomerase I 2E-52

protein kinase family protein $1 \mathrm{E}-16$

halotolerance protein (HAL3A) 2E-42

expressed protein $\quad 9 \mathrm{E}-75$

$\begin{array}{ll}\text { expressed protein } & 7 \mathrm{E}-22\end{array}$

pseudo-response regulator 7 (APRR7) 2E-12

translin family protein $\quad 5 \mathrm{E}-57$

expressed protein $1 \mathrm{E}-14$

expressed protein $\quad 5 \mathrm{E}-28$

$\begin{array}{ll}\text { leucine-rich repeat transmembrane protein kinase } & 1 \mathrm{E}-47\end{array}$

DNAJ heat shock $\mathrm{N}$-terminal domain-containing protein

$3 \mathrm{E}-47$ 



\section{Unigenes de cítricos implicados en la biosíntesis de diversos terpenoides}

\section{I.1. Terpenoides derivados de GGPP}

\section{I.1.1. Biosínstesis de tocoferol}

BIOSÍNTESIS DE TOCOFEROL

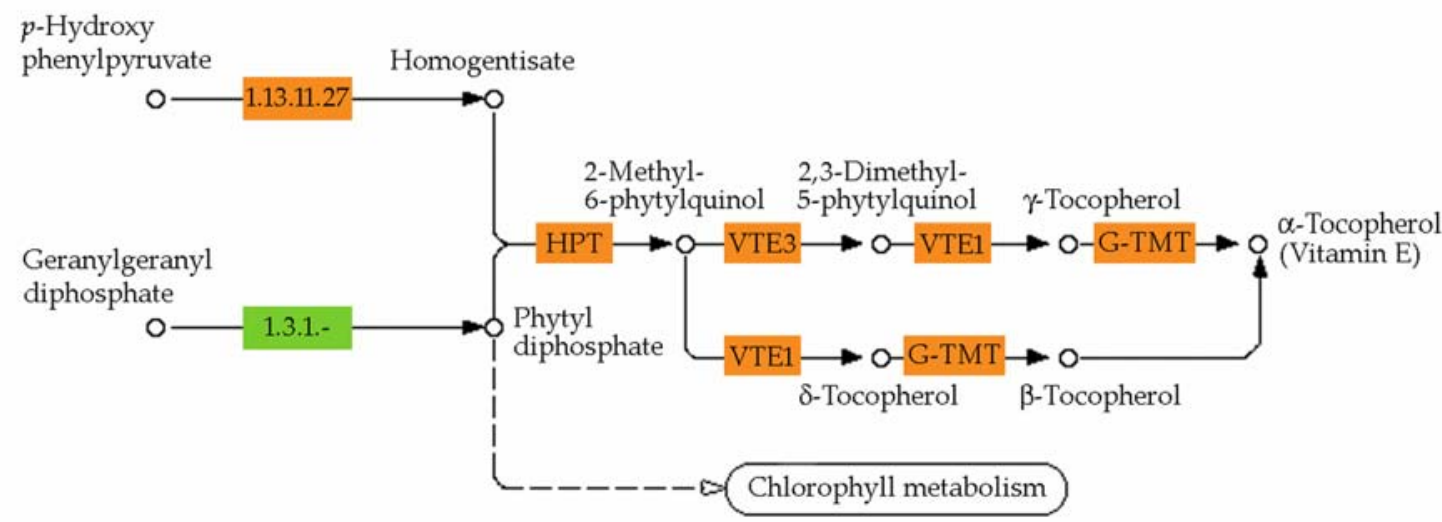

Fig. A1. Esquema de biosíntesis de tocoferoles en cítricos. Las cajas verdes indican los pasos para los que se identificaron ESTs procedentes de la genoteca Veg1 y las naranjas aquellos pasos para los que se encontraron los candidatos correspondientes en las demás genotecas del CFGP.

En la base de datos del CFGP fue posible identificar ESTs de cítricos correspondientes a cada una de las enzimas implicadas en la síntesis de tocoferol (Tabla A1).

\begin{tabular}{lccccc}
\hline \multicolumn{1}{c}{ Tabla A1. Unigenes de cítricos que codifican enzimas de biosíntesis de tocoferol } & & \\
\hline \multicolumn{1}{c}{ Enzimas } & EC & $\begin{array}{c}\text { Gen de ATH } \\
\text { más similar }\end{array}$ & Contigs & Singletons & $\begin{array}{c}\text { Total } \\
\text { ESTs }\end{array}$ \\
\hline Geranilgeranil reductasa (GGR) & $1.3 .1 .-$ & At1g74470 & 2 & 0 & 35 \\
4-Hidroxifenilpiruvato dioxigenasa & 1.13 .11 .27 & At1g06570 & 1 & 1 & 21 \\
Homogentisato fitilpreniltransferasa (HPT) & & At2g18950 & 8 & 6 & 36 \\
MPBQ/MSBQ-metiltransferasa (VTE3) & $2.1 .1 .-$ & At3g63410 & 2 & 0 & 11 \\
Tocoferol ciclasa (VTE1) & & At4g32770 & 2 & 1 & 24 \\
Gamma-tocoferol metiltransferasa (G-TMT) & 2.1 .1 .95 & At1g64970 & 1 & 1 & 24 \\
\hline
\end{tabular}




\section{I.1.2. Biosíntesis de carotenoides}

\section{BIOSÍNTESIS DE CAROTENOIDES}

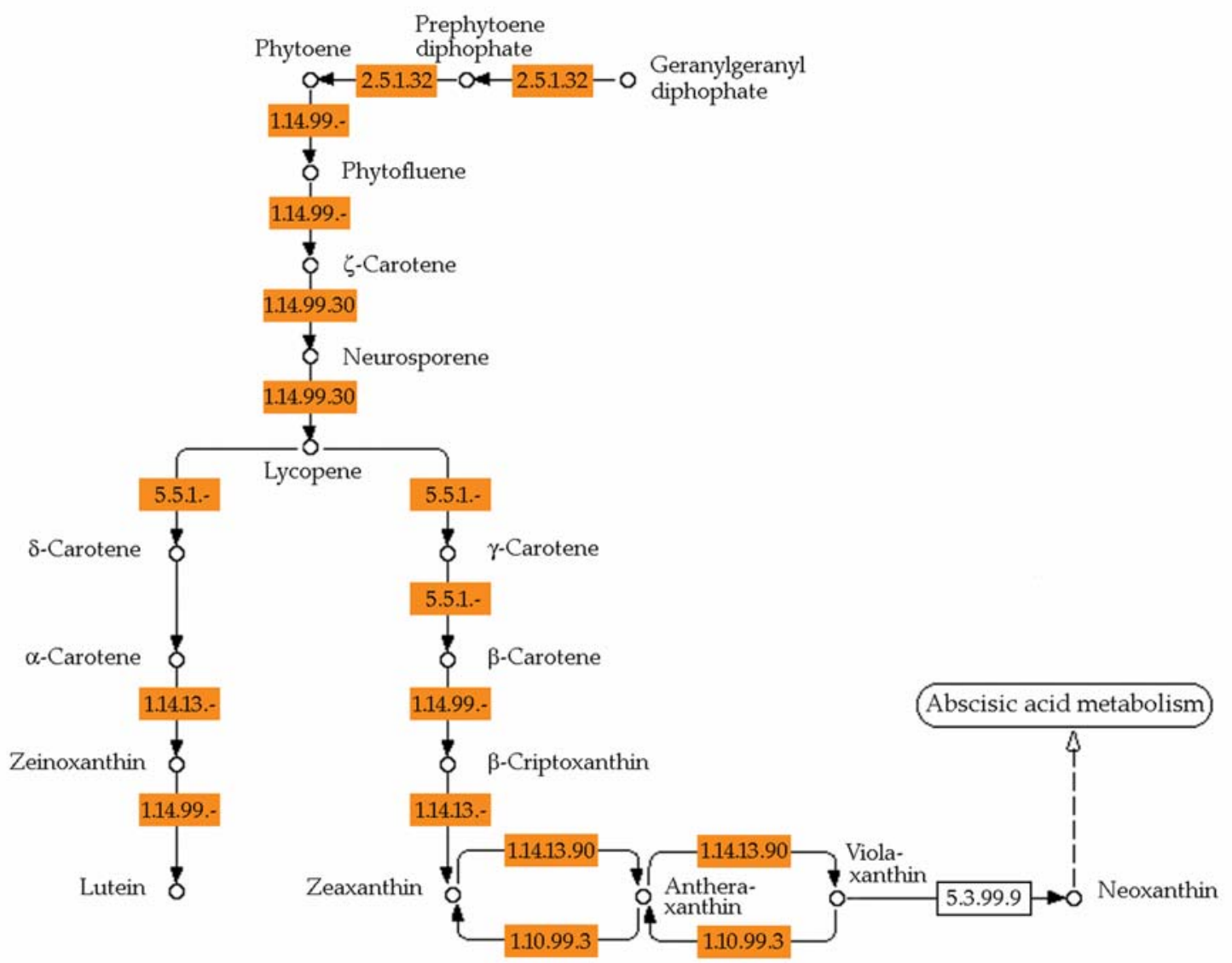

Fig. A2. Esquema de biosíntesis de carotenoides en cítricos. Las cajas naranjas representan los pasos para los que se identificaron los genes candidatos a partir de la colección de ESTs del CFGP.

En la base de datos del CFGP fue posible identificar ESTs de cítricos correspondientes a cada una de las enzimas implicadas en la biosíntesis de carotenoides (Tabla A2).

\begin{tabular}{lllccc}
\hline \multicolumn{7}{l}{ Tabla A2. Unigenes de cítricos que codifican enzimas de biosíntesis de carotenoides } \\
\hline \multicolumn{1}{c}{ Enzimas } & EC & $\begin{array}{c}\text { Gen de ATH } \\
\text { más similar }\end{array}$ & Contigs & Singletons & $\begin{array}{c}\text { Total } \\
\text { ESTs }\end{array}$ \\
\hline Fitoeno sintasa (PSY) & 2.5 .1 .32 & At5g17230 & 2 & 2 & 7 \\
Fitoeno dehidrogenasa (PSD) & $1.14 .99 .-$ & At4g14210 & 1 & 2 & 4 \\
zeta-Caroteno desaturasa (ZDS) & 1.14 .99 .30 & At3g04870 & 3 & 1 & 14 \\
Licopeno epsilon ciclasa ( $\varepsilon$-LCY) & $5.5 .1 .-$ & At5g57030 & 1 & 2 & 4 \\
Carotenoide $\beta$-ring hidroxilasa ( $\beta-C H X)$ & $1.14 .13 .-$ & At4g25700 & 2 & 0 & 38 \\
Carotenoide $\varepsilon$-ring hidroxilasa ( $\varepsilon-C H X)$ & $1.14 .99 .-$ & At3g53130 & 1 & 0 & 2 \\
Licopeno beta ciclasa ( $\beta$-LYC) & $5.5 .1 .-$ & At3g10230 & 3 & 0 & 33 \\
Zeaxantina epoxidasa (ZEP, ABA1) & 1.14 .13 .90 & At5g67030 & 2 & 3 & 21 \\
Violaxantina de-epoxidasa (VDE) & 1.10 .99 .3 & At1g08550 & 0 & 2 & 2 \\
\hline
\end{tabular}


I.1.3. Metabolismo del ácido abscísico

METABOLISMO DEL ÁCIDO ABSCÍSICO

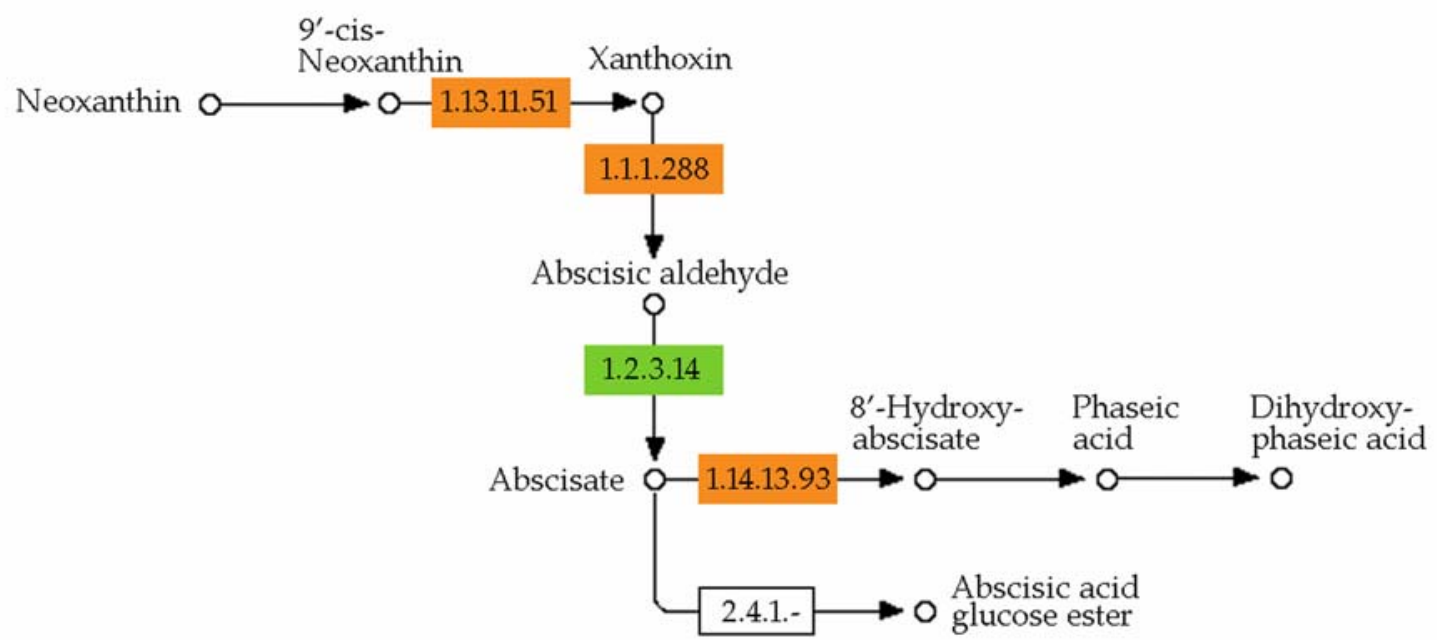

Fig. A3. Esquema del metabolismo del ácido abscísico en cítricos. Las cajas verdes indican los pasos para los que se identificaron ESTs procedentes de la genoteca Veg1 y las naranjas aquellos pasos para los que se encontraron los candidatos correspondientes en las demás genotecas del CFGP.

En la base de datos del CFGP fue posible identificar ESTs de cítricos correspondientes a cada una de las enzimas implicadas en el metabolismo del ácido abscísico (Tabla A3).

\begin{tabular}{lccccc}
\hline \multicolumn{1}{l}{ Tabla A3. Unigenes de cítricos que codifican enzimas del metabolismo del ácido abscísico } \\
\hline \multicolumn{1}{c}{ Enzimas } & EC & $\begin{array}{c}\text { Gen de ATH } \\
\text { más similar }\end{array}$ & Contigs & Singletons & $\begin{array}{c}\text { Total } \\
\text { ESTs }\end{array}$ \\
\hline Biosíntesis & & & & & \\
9-cis-epoxycarotenoide dioxigenasa & 1.13 .11 .51 & At1g30100 & 2 & 1 & 12 \\
& & At3g14440 & 1 & 2 & 11 \\
Xantoxina dehidrogenasa (ABA2) & 1.1 .1 .288 & At1g52340 & 1 & 2 & 6 \\
Abscísico aldehido oxidasa (AAO3) & 1.2 .3 .14 & At2g27150 & - & 2 & 2 \\
Catabolismo & & & & & \\
Ácido abscísico 8'-hidroxilasa & 1.14 .13 .93 & At3g19270 & 2 & 2 & 15 \\
& & At2g29090 & 2 & 0 & 6 \\
& & At4g19230 & 3 & 0 & 11 \\
Ácido abscísico glucosiltransferasa & $2.4 .1 .-$ & At4g34131 & 1 & 0 & 2 \\
& & At1g05530 & 3 & 0 & 15 \\
& & At2g23250 & 1 & 0 & 24 \\
& & At2g23260 & 1 & 0 & 8 \\
\hline
\end{tabular}




\section{I.2. Terpenoides derivados de GGPP y FPP}

\section{I.2.1. Biosíntesis de plastoquinona}

BIOSÍNTESIS DE UBIQUINONA

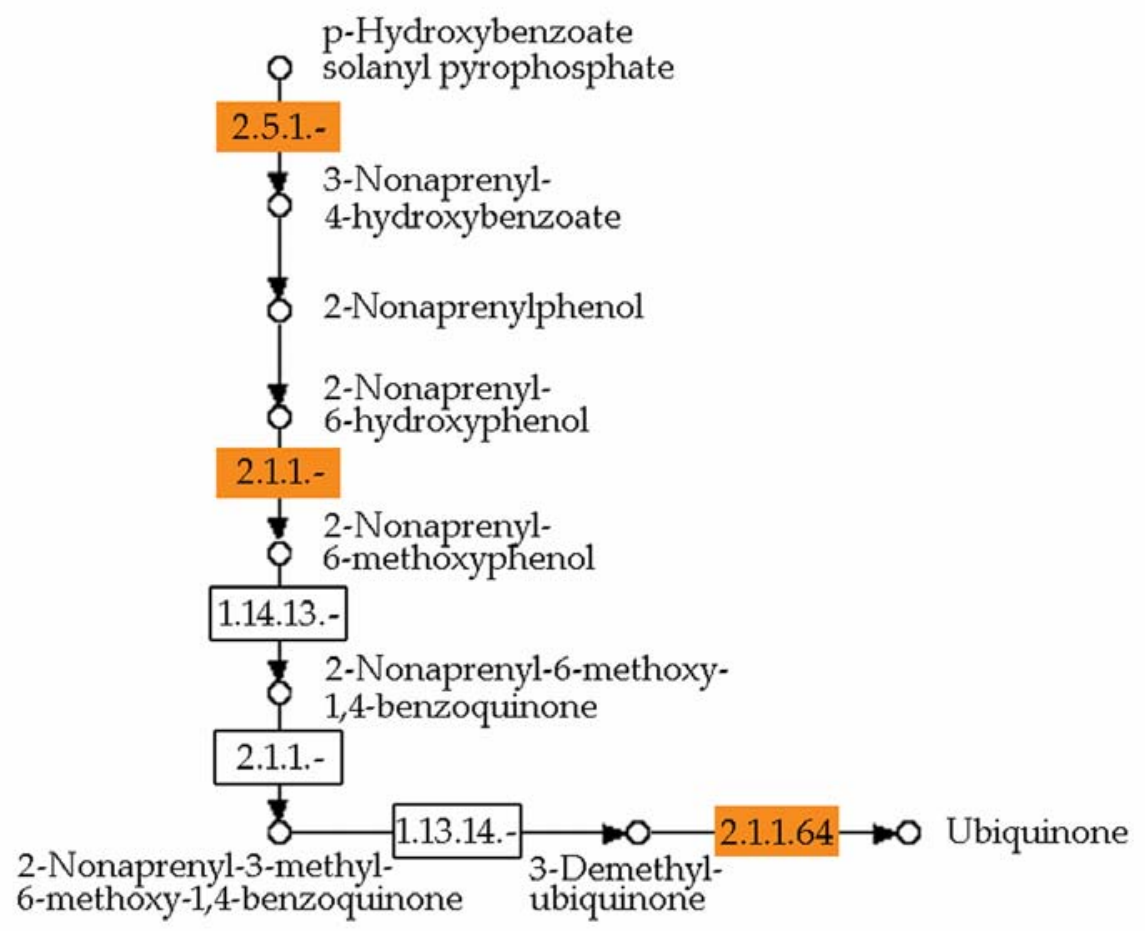

Fig. A4. Esquema de biosíntesis de ubiquinona en cítricos. Las cajas naranjas representan los pasos para los que se identificaron los genes candidatos a partir de la colección de ESTs del CFGP.

En la base de datos del CFGP fue posible identificar ESTs de cítricos correspondientes a cada una de las enzimas implicadas en la biosíntesis de ubiquinona (Tabla A4).

\begin{tabular}{lccccc}
\hline \multicolumn{4}{l}{ Tabla A4. Unigenes de cítricos que codifican enzimas de biosíntesis de ubiquinona } & & \multicolumn{1}{c}{ Enzimas } \\
\multicolumn{1}{c}{ EC } & $\begin{array}{c}\text { Gen de ATH } \\
\text { más similar }\end{array}$ & Contigs & Singletons & $\begin{array}{c}\text { Total } \\
\text { ESTs }\end{array}$ \\
\hline $\begin{array}{l}\text { Hidroxibenzoato poliprenilo difosfato } \\
\text { transferasa (PPT) }\end{array}$ & $2.5 .1 .-$ & At4g23660 & 1 & 1 & 15 \\
$\begin{array}{l}\text { Nonaprenildihidroxibenzoato metiltransferasa } \\
\text { Nonaprenildihidroxibenzoato metiltransferasa }\end{array}$ & $2.1 .1 .-$ & At2g30920 & 1 & 0 & 2 \\
\hline
\end{tabular}




\section{I.2.2. Biosíntesis de plastoquinona}

BIOSÍNTESIS DE PLASTOQUINONA

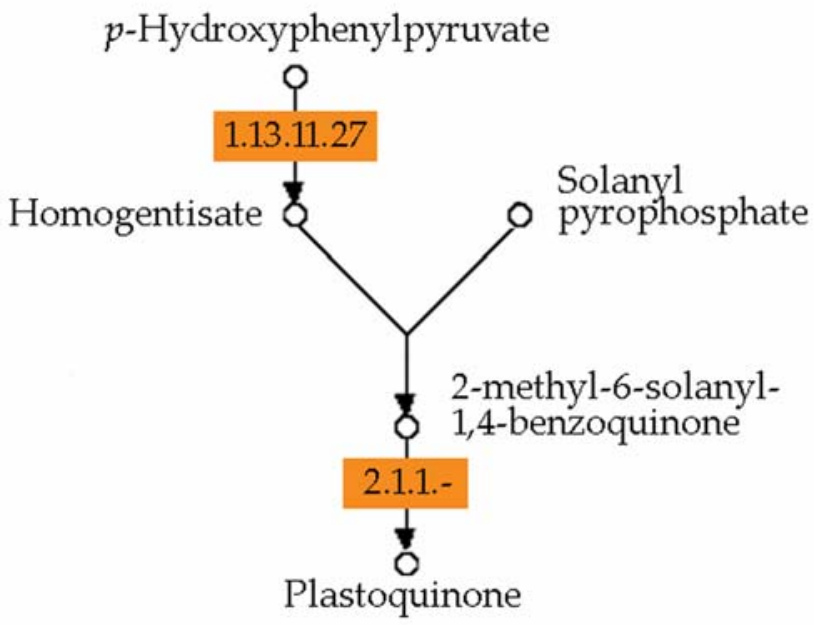

Fig. A5. Esquema de biosíntesis de plastoquinona en cítricos. Las cajas naranjas representan los pasos para los que se identificaron los genes candidatos a partir de la colección de ESTs del CFGP.

En la base de datos del CFGP fue posible identificar ESTs de cítricos correspondientes a cada una de las enzimas implicadas en la biosíntesis de plastoquinona (Tabla A5).

\begin{tabular}{lccccc}
\hline Tabla A5. Unigenes de cítricos que codifican enzimas de biosíntesis de plastoquinona & \\
\hline \multicolumn{1}{c}{ Enzimas } & EC & $\begin{array}{c}\text { Gen de ATH } \\
\text { más similar }\end{array}$ & Contigs & Singletons & $\begin{array}{c}\text { Total } \\
\text { ESTs }\end{array}$ \\
\hline 4-Hidroxifenilpiruvato dioxigenasa & 1.13 .11 .27 & At1g06570 & 1 & 1 & 21 \\
MPBQ/MSBQ-metiltransferasa (VTE3) & $2.1 .1 .-$ & At3g63410 & 2 & 0 & 11 \\
\hline
\end{tabular}




\section{I.3. Terpenoides derivados de FPP}

\section{l.3.1. Biosíntesis de esteroles}

STEROLS BIOSYNTHESIS

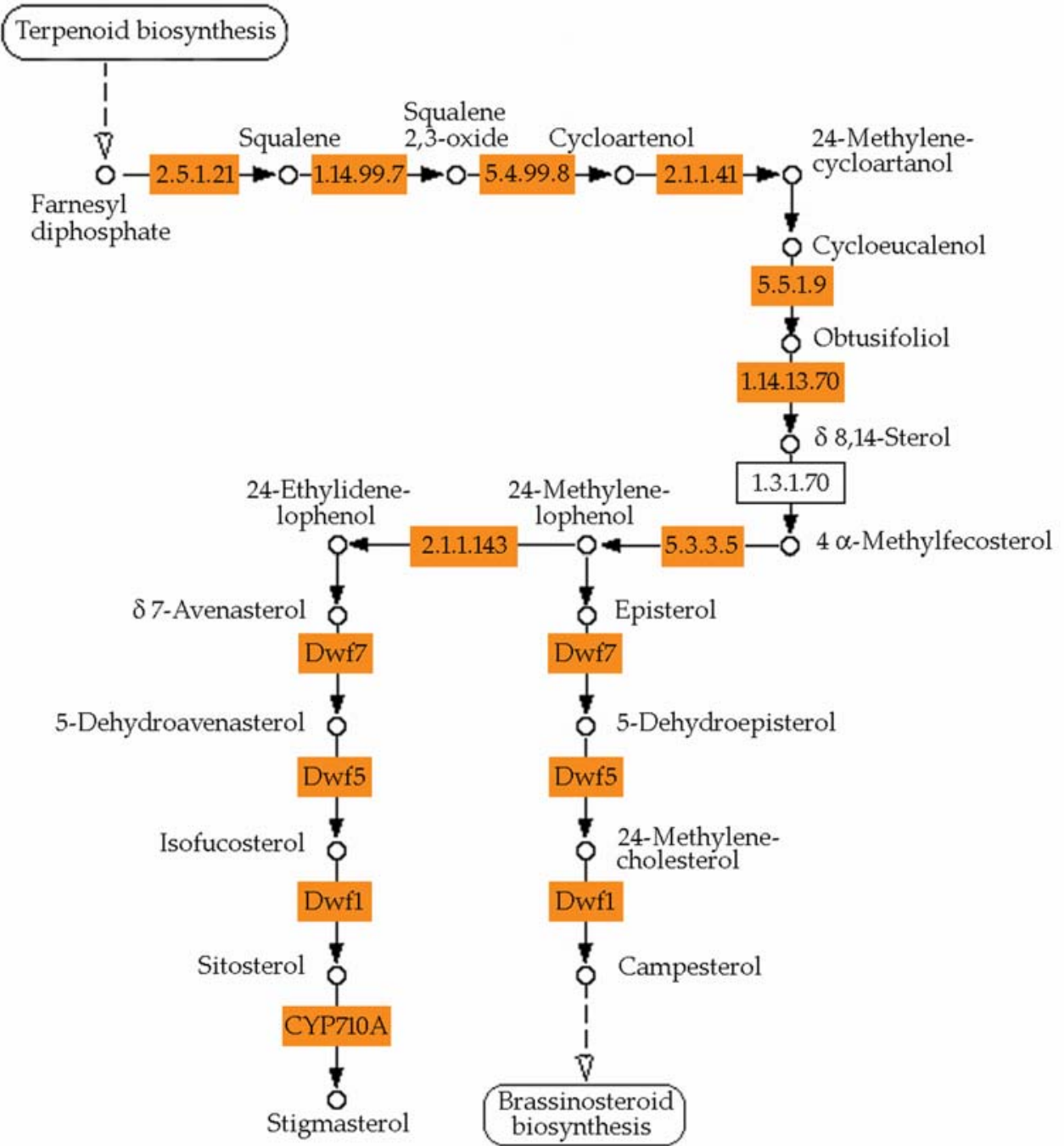

Fig. A6. Esquema de biosíntesis de esteroles en cítricos. Las cajas naranjas representan los pasos para los que se identificaron los genes candidatos a partir de la colección de ESTs del CFGP. 
En la base de datos del CFGP fue posible identificar ESTs de cítricos correspondientes a cada una de las enzimas implicadas en la biosíntesis de esteroles (Tabla A6).

Tabla A6. Unigenes de cítricos que codifican enzimas de biosíntesis de esteroles

\begin{tabular}{lllrrr}
\hline \multicolumn{1}{c}{ Enzimas } & EC & $\begin{array}{c}\text { Gen de ATH } \\
\text { más similar }\end{array}$ & Contigs & $\begin{array}{r}\text { Singletons } \\
\text { ESTs }\end{array}$ \\
\hline Escualeno sintasa & 2.5 .1 .21 & AT4G34640 & 0 & 1 & 1 \\
Escualeno monooxigenasa & 1.14 .99 .7 & AT1G58440 & 1 & 0 & 7 \\
& & AT4G37760 & 1 & 2 & 5 \\
Cicloartenol sintasa & 5.4 .99 .8 & AT2G07050 & 0 & 3 & 3 \\
Esterol 24-C-metiltransferasa & 2.1 .1 .41 & AT5G13710 & 2 & 0 & 5 \\
Cicloeucalenol cicloisomerasa & 5.5 .1 .9 & AT5G50375 & 1 & 0 & 4 \\
Esterol 14-demetilasa & 1.14 .13 .70 & AT1G11680 & 1 & 2 & 5 \\
Delta 14-esterol reductasa & 1.3 .1 .70 & AT3G52940 & - & - & - \\
Colestenol delta-isomerasa & 5.3 .3 .5 & AT1G20050 & 1 & 1 & 3 \\
24-metilenesterol C-metiltransferasa & 2.1 .1 .143 & AT1G20330 & 2 & 0 & 13 \\
C-5 esterol desaturasa (DWF7) & 1.14 .21 .6 & AT3G02580 & 0 & 1 & 1 \\
Esterol delta 7-reductasa (DWF5) & 1.3 .1 .21 & AT1G50430 & 1 & 0 & 3 \\
Delta 24-esterol reductasa (DWF1) & 1.3 .1 .72 & AT3G19820 & - & - & - \\
C-22 esterol desaturasa (CYP710A) & $1.3 .1 .-$ & AT2G34500 & 1 & 0 & 7 \\
\hline
\end{tabular}





\begin{tabular}{|c|c|c|c|c|}
\hline \multicolumn{5}{|c|}{$\begin{array}{l}\text { Anejo III. Unigenes de cítricos representados en la micromatriz CIT1 que codifican factores de } \\
\text { transcripción y/o reguladores de la transcripción }\end{array}$} \\
\hline Family & Citrus unigene & AGI code & Description & E-value \\
\hline ABI3VP1 & aCL7219Contig1 & At3g18990 & transcriptional factor B3 family protein & $1 \mathrm{E}-81$ \\
\hline ABI3VP1 & aCL7325Contig1 & At3g18990 & transcriptional factor B3 family protein & $6 \mathrm{E}-40$ \\
\hline ABI3VP1 & aCL4518Contig1 & At4g32010 & transcriptional factor B3 family protein & $2 \mathrm{E}-62$ \\
\hline Alfin-like & aCL3306Contig1 & At1g14510 & PHD finger family protein & $1 \mathrm{E}-101$ \\
\hline AP2-EREBP & aCL8Contig7 & At1g50640 & ethylene response factor (ERF) subfamily B-1 & $1 \mathrm{E}-22$ \\
\hline AP2-EREBP & aCL89Contig1 & At3g14230 & ethylene response factor (ERF) subfamily B-2 & $1 E-68$ \\
\hline AP2-EREBP & aCL152Contig1 & At3g14230 & ethylene response factor (ERF) subfamily B-2 & $5 E-32$ \\
\hline AP2-EREBP & aCL524Contig1 & At3g15210 & ethylene response factor (ERF) subfamily B-1 & $6 \mathrm{E}-21$ \\
\hline AP2-EREBP & aC02007E03SK_c & At5g11190 & ethylene response factor (ERF) subfamily B-6 & $2 \mathrm{E}-47$ \\
\hline AP2-EREBP & aCL2849Contig1 & At5g13330 & ethylene response factor (ERF) subfamily B-4 & $3 E-35$ \\
\hline AP2-EREBP & aCL396Contig1 & At5g13330 & ethylene response factor (ERF) subfamily B-4 & $3 E-28$ \\
\hline AP2-EREBP & aCL1567Contig1 & At5g44210 & ethylene response factor (ERF) subfamily B-1 & $3 E-23$ \\
\hline ARF & aC03006F12SK_c & At1g30330 & auxin-responsive factor (ARF6) & $8 \mathrm{E}-71$ \\
\hline ARF & aCL2271Contig1 & At1g59750 & auxin-responsive factor AUX/IAA-related & 0 \\
\hline ARF & aCL3486Contig1 & At5g62000 & auxin-responsive factor & $1 \mathrm{E}-129$ \\
\hline $\mathrm{bHLH}$ & aCL8856Contig1 & At1g09250 & transcription factor & $8 \mathrm{E}-33$ \\
\hline $\mathrm{bHLH}$ & aC02020G06SK_c & At1g09530 & phytochrome interacting factor 3 (PIF3) & $3 \mathrm{E}-17$ \\
\hline $\mathrm{bHLH}$ & aCL8145Contig1 & At1g22380 & basic helix-loop-helix transcription factor & $5 E-56$ \\
\hline $\mathrm{bHLH}$ & aC03004B03SK_c & At1g22380 & basic helix-loop-helix transcription factor & $2 \mathrm{E}-72$ \\
\hline $\mathrm{bHLH}$ & aCL5746Contig1 & At1g29950 & transcription factor & $1 \mathrm{E}-22$ \\
\hline $\mathrm{bHLH}$ & aCL3615Contig1 & At1g59640 & basic helix-loop-helix (bHLH) family protein & $2 \mathrm{E}-72$ \\
\hline $\mathrm{bHLH}$ & aC20002B11SK_c & At1g69010 & basic helix-loop-helix (bHLH) family protein & $3 E-61$ \\
\hline bHLH & aC20002E09SK_c & At2g42280 & basic helix-loop-helix (bHLH) family protein & $1 \mathrm{E}-16$ \\
\hline $\mathrm{bHLH}$ & aCL3157Contig1 & At2g46970 & basic helix-loop-helix (bHLH) protein & $7 \mathrm{E}-31$ \\
\hline $\mathrm{bHLH}$ & aCL9380Contig1 & At3g07340 & basic helix-loop-helix (bHLH) family protein & $1 \mathrm{E}-36$ \\
\hline bHLH & aCL2290Contig2 & At3g17100 & transcription factor & $1 \mathrm{E}-36$ \\
\hline bHLH & aCL2564Contig1 & At4g01460 & basic helix-loop-helix (bHLH) family protein & $9 E-45$ \\
\hline $\mathrm{bHLH}$ & aCL9448Contig1 & At4g14410 & basic helix-loop-helix (bHLH) family protein & $3 E-66$ \\
\hline $\mathrm{bHLH}$ & aCL7683Contig1 & At4g20970 & basic helix-loop-helix (bHLH) family protein & $2 E-23$ \\
\hline $\mathrm{bHLH}$ & aC18016G11Rv_c & At4g25410 & basix helix-loop-helix (bHLH) family protein & $8 \mathrm{E}-22$ \\
\hline $\mathrm{bHLH}$ & aC04015F06SK_c & At4g29100 & ethylene-responsive family protein & $1 E-52$ \\
\hline $\mathrm{bHLH}$ & aC08014B07SK_c & At4g29100 & ethylene-responsive family protein & $2 \mathrm{E}-39$ \\
\hline bHLH & aCL488Contig3 & At5g09460 & transcription factor & $6 \mathrm{E}-16$ \\
\hline bZIP & aCL6889Contig1 & At1g08320 & bZIP family transcription factor & $2 \mathrm{E}-23$ \\
\hline bZIP & aCL3553Contig1 & At1g45249 & ABA-responsive element-binding protein & $2 \mathrm{E}-74$ \\
\hline bZIP & aCL474Contig1 & At3g19290 & ABA-responsive element-binding protein 2 & $3 E-76$ \\
\hline bZIP & aCL7631Contig1 & At3g56850 & ABA-responsive element-binding protein 3 & $8 \mathrm{E}-46$ \\
\hline bZIP & aCL2910Contig1 & At3g58120 & bZIP transcription factor family protein & $4 \mathrm{E}-73$ \\
\hline bZIP & aC08005F12SK_c & At3g62420 & bZIP transcription factor family protein & $1 \mathrm{E}-12$ \\
\hline bZIP & aCL3546Contig1 & At3g62420 & bZIP transcription factor family protein & $4 \mathrm{E}-48$ \\
\hline bZIP & aCL4220Contig1 & At4g34590 & bZIP transcription factor family protein & $3 E-27$ \\
\hline bZIP & aC04015B01SK_c & At4g38900 & bZIP family transcription factor & $4 \mathrm{E}-31$ \\
\hline bZIP & aCL2063Contig1 & At5g44080 & bZIP transcription factor family protein & $4 \mathrm{E}-26$ \\
\hline C2C2-CO-like & aC03003C09SK_c & At1g28050 & zinc finger (B-box type) family protein & $2 E-34$ \\
\hline C2C2-CO-like & aC05014D03SK_c & At4g27310 & zinc finger (B-box type) family protein & $8 \mathrm{E}-29$ \\
\hline C2C2-CO-like & aCL1873Contig2 & At4g27310 & zinc finger (B-box type) family protein & $4 \mathrm{E}-31$ \\
\hline C2C2-CO-like & aCL475Contig1 & At5g24930 & zinc finger (B-box type) family protein & $1 \mathrm{E}-115$ \\
\hline C2C2-Dof & aC08003G05SK_c & At4g24060 & Dof-type zinc finger domain-containing protein & $6 \mathrm{E}-32$ \\
\hline C2C2-Dof & aCL6670Contig1 & At5g62940 & Dof-type zinc finger domain-containing protein & $6 \mathrm{E}-22$ \\
\hline C2C2-Gata & aCL4896Contig1 & At1g08010 & zinc finger (GATA type) family protein & $3 E-43$ \\
\hline C2C2-YABBY & aC02019G10SK_c & At1g69180 & transcription factor CRC (CRABS CLAW) & $1 \mathrm{E}-42$ \\
\hline C2C2-YABBY & aCL4611Contig1 & At2g26580 & plant-specific transcription factor YABBY & $8 \mathrm{E}-67$ \\
\hline C2C2-YABBY & aCL4648Contig1 & At2g26580 & plant-specific transcription factor YABBY & $6 \mathrm{E}-18$ \\
\hline $\mathrm{C} 2 \mathrm{H} 2$ & aCL684Contig2 & At1g04850 & ubiquitin-associated (UBA)/TS-N protein & $1 \mathrm{E}-73$ \\
\hline $\mathrm{C} 2 \mathrm{H} 2$ & aCL684Contig1 & At1g04850 & ubiquitin-associated (UBA)/TS-N protein & $1 \mathrm{E}-139$ \\
\hline
\end{tabular}




\begin{tabular}{|c|c|c|c|c|}
\hline $\mathrm{C} 2 \mathrm{H} 2$ & aCL146Contig1 & At1g27730 & salt tolerance zinc finger protein (STZ) & $4 \mathrm{E}-48$ \\
\hline $\mathrm{C} 2 \mathrm{H} 2$ & aCL382Contig1 & At1g27730 & salt tolerance zinc finger protein (STZ) & $1 E-38$ \\
\hline $\mathrm{C} 2 \mathrm{H} 2$ & aCL335Contig1 & At1g30970 & supressor of frigida 4 (SUF4) & $1 \mathrm{E}-104$ \\
\hline $\mathrm{C} 2 \mathrm{H} 2$ & aC07001D04SK_c & At1g43860 & transcription factor & $3 \mathrm{E}-25$ \\
\hline $\mathrm{C} 2 \mathrm{H} 2$ & aCL5005Contig1 & At1g50670 & OTU-like cysteine protease family protein & $1 \mathrm{E}-100$ \\
\hline $\mathrm{C} 2 \mathrm{H} 2$ & aCL5478Contig1 & At2g27100 & zinc-finger ( $\mathrm{C} 2 \mathrm{H} 2$ type) protein SERRATE (SE) & $1 E-30$ \\
\hline $\mathrm{C} 2 \mathrm{H} 2$ & aCL5095Contig1 & At2g27760 & tRNA isopentenyltransferase & $1 \mathrm{E}-111$ \\
\hline $\mathrm{C} 2 \mathrm{H} 2$ & aC08010C06SK_c & At2g28710 & zinc finger ( $\mathrm{C} 2 \mathrm{H} 2$ type) family protein & $3 E-22$ \\
\hline $\mathrm{C} 2 \mathrm{H} 2$ & aCL3682Contig1 & At3g02790 & zinc finger ( $\mathrm{C} 2 \mathrm{H} 2$ type) family protein & $4 \mathrm{E}-43$ \\
\hline $\mathrm{C} 2 \mathrm{H} 2$ & aCL5429Contig1 & At3g02860 & expressed protein & $4 \mathrm{E}-32$ \\
\hline $\mathrm{C} 2 \mathrm{H} 2$ & aC02021A12SK_c & At3g07940 & zinc finger and $\mathrm{C} 2$ domain protein & $1 \mathrm{E}-28$ \\
\hline $\mathrm{C} 2 \mathrm{H} 2$ & aCL7490Contig1 & At3g12270 & methyltransferase family protein & $2 E-38$ \\
\hline $\mathrm{C} 2 \mathrm{H} 2$ & aCL1165Contig1 & At3g52800 & zinc finger (AN1-like) family protein & $2 \mathrm{E}-49$ \\
\hline $\mathrm{C} 2 \mathrm{H} 2$ & aCL8194Contig1 & At4g16845 & vernalization 2 protein (VRN2) & $5 E-42$ \\
\hline $\mathrm{C} 2 \mathrm{H} 2$ & aCL2974Contig1 & At4g31420 & zinc finger ( $\mathrm{C} 2 \mathrm{H} 2$ type) family protein & $1 \mathrm{E}-116$ \\
\hline $\mathrm{C} 2 \mathrm{H} 2$ & aCL5281Contig1 & At5g03740 & zinc finger ( $\mathrm{C} 2 \mathrm{H} 2$ type) family protein & $3 E-24$ \\
\hline $\mathrm{C} 2 \mathrm{H} 2$ & aCL650Contig1 & At5g64610 & histone acetyltransferase & 0 \\
\hline $\mathrm{C} 2 \mathrm{H} 2$ & aCL2178Contig1 & At5g66730 & zinc finger ( $\mathrm{C} 2 \mathrm{H} 2$ type) family protein & $8 \mathrm{E}-24$ \\
\hline $\mathrm{C} 3 \mathrm{H}$ & aCL2110Contig1 & At1g11020 & zinc finger (C3HC4-type RING) family protein & $1 \mathrm{E}-119$ \\
\hline $\mathrm{C} 3 \mathrm{H}$ & aCL3598Contig1 & At1g15100 & zinc finger (C3HC4-type RING) family protein & $2 \mathrm{E}-31$ \\
\hline $\mathrm{C} 3 \mathrm{H}$ & aCL7031Contig1 & At1g50440 & zinc finger (C3HC4-type RING) family protein & $3 E-26$ \\
\hline $\mathrm{C} 3 \mathrm{H}$ & aCL466Contig1 & At1g68070 & zinc finger (C3HC4-type RING) family protein & $1 E-89$ \\
\hline $\mathrm{C} 3 \mathrm{H}$ & aCL1354Contig1 & At1g73760 & zinc finger (C3HC4-type RING) family protein & 7E-39 \\
\hline $\mathrm{C} 3 \mathrm{H}$ & aCL4880Contig1 & At1g73950 & zinc finger (C3HC4-type RING) family protein & $4 \mathrm{E}-68$ \\
\hline $\mathrm{C} 3 \mathrm{H}$ & aCL198Contig1 & At2g04240 & zinc finger (C3HC4-type RING) family protein & $4 \mathrm{E}-44$ \\
\hline $\mathrm{C} 3 \mathrm{H}$ & aCL2811Contig1 & At2g31510 & similar to zinc finger protein & $1 \mathrm{E}-176$ \\
\hline $\mathrm{C} 3 \mathrm{H}$ & aCL7612Contig1 & At2g37150 & zinc finger (C3HC4-type RING) family protein & $2 \mathrm{E}-09$ \\
\hline $\mathrm{C} 3 \mathrm{H}$ & aC20009E07SK_c & At2g46495 & zinc finger (C3HC4-type RING) family protein & $4 \mathrm{E}-14$ \\
\hline $\mathrm{C} 3 \mathrm{H}$ & aC18006A08Rv_c & At2g46495 & zinc finger (C3HC4-type RING) family protein & $4 \mathrm{E}-13$ \\
\hline $\mathrm{C} 3 \mathrm{H}$ & aCL7967Contig1 & At3g02340 & zinc finger (C3HC4-type RING) family protein & $3 E-31$ \\
\hline $\mathrm{C} 3 \mathrm{H}$ & aCL548Contig1 & At3g09770 & zinc finger (C3HC4-type RING) family protein & $1 \mathrm{E}-105$ \\
\hline $\mathrm{C} 3 \mathrm{H}$ & aCL812Contig1 & At3g16090 & zinc finger (C3HC4-type RING) family protein & $1 \mathrm{E}-177$ \\
\hline $\mathrm{C} 3 \mathrm{H}$ & aCL3130Contig1 & At3g55530 & zinc finger (C3HC4-type RING) family protein & $2 \mathrm{E}-53$ \\
\hline $\mathrm{C} 3 \mathrm{H}$ & aCL3130Contig2 & At3g55530 & zinc finger (C3HC4-type RING) family protein & $4 \mathrm{E}-29$ \\
\hline $\mathrm{C} 3 \mathrm{H}$ & aCL7954Contig1 & At3g58030 & zinc finger (C3HC4-type RING) family protein & $2 \mathrm{E}-63$ \\
\hline $\mathrm{C} 3 \mathrm{H}$ & aCL3447Contig1 & At4g33565 & zinc finger (C3HC4-type RING) family protein & $1 \mathrm{E}-41$ \\
\hline $\mathrm{C} 3 \mathrm{H}$ & aC02003G02SK_c & At5g08750 & zinc finger (C3HC4-type RING) family protein & $6 \mathrm{E}-24$ \\
\hline $\mathrm{C} 3 \mathrm{H}$ & aCL8387Contig1 & At5g08750 & zinc finger (C3HC4-type RING) family protein & $2 \mathrm{E}-43$ \\
\hline $\mathrm{C} 3 \mathrm{H}$ & aCL4888Contig1 & At5g20910 & zinc finger (C3HC4-type RING) family protein & $1 \mathrm{E}-102$ \\
\hline $\mathrm{C} 3 \mathrm{H}$ & aCL5150Contig1 & At5g38895 & zinc finger (C3HC4-type RING) family protein & $1 E-33$ \\
\hline $\mathrm{C} 3 \mathrm{H}$ & aCL2517Contig2 & At5g41350 & zinc finger (C3HC4-type RING) family protein & $2 \mathrm{E}-49$ \\
\hline CAMTA & aCL5719Contig1 & At5g64220 & calmodulin-binding transcription activator & $2 \mathrm{E}-95$ \\
\hline CCAAT-DR1 & aCL2659Contig1 & At5g23090 & TATA-binding protein & $5 E-55$ \\
\hline ССAAT-HAP3 & aCL5582Contig1 & At3g53340 & CCAAT-box binding transcription factor & $2 \mathrm{E}-51$ \\
\hline ССАAT-HAPЗ & aCL1964Contig1 & At4g14540 & CCAAT-box binding transcription factor (HAP3) & $2 \mathrm{E}-50$ \\
\hline CCAAT-HAP5 & aCL665Contig2 & At1g08970 & CCAAT-box binding transcription factor Hap5a & $7 \mathrm{E}-68$ \\
\hline CCAAT-HAP5 & aCL665Contig1 & At1g08970 & CCAAT-box binding transcription factor Hap5a & $1 \mathrm{E}-60$ \\
\hline CCAAT-HAP5 & aC01008E03SK_c & At3g48590 & CCAAT-box binding transcription factor Hap5a & $2 \mathrm{E}-56$ \\
\hline EIL & aCL5023Contig1 & At2g27050 & ethylene-insensitive3-like1 (EIL1) & $7 \mathrm{E}-22$ \\
\hline EIL & aCL1330Contig1 & At3g20770 & ethylene-insensitive 3 (EIN3) & 0 \\
\hline G2-like & aCL319Contig1 & At1g25550 & myb family transcription factor & $3 \mathrm{E}-77$ \\
\hline G2-like & aCL4426Contig1 & At2g01060 & myb family transcription factor & $1 E-57$ \\
\hline G2-like & aC02013H09SK_c & At3g13040 & myb family transcription factor & $5 E-10$ \\
\hline G2-like & aCL4279Contig1 & At4g13640 & myb family transcription factor & $2 \mathrm{E}-51$ \\
\hline G2-like & aC01010A07SK_c & At5g06800 & myb family transcription factor & $1 E-28$ \\
\hline G2-like & aCL7275Contig1 & At5g29000 & myb family transcription factor & $7 \mathrm{E}-49$ \\
\hline GeBP & aCL2740Contig1 & At5g14280 & DNA-binding storekeeper protein-related & $2 \mathrm{E}-42$ \\
\hline GRAS & aCL7712Contig1 & At1g21450 & scarecrow-like transcription factor 1 (SCL1) & $1 \mathrm{E}-106$ \\
\hline
\end{tabular}




\begin{tabular}{|c|c|c|c|c|}
\hline GRAS & aCL3705Contig1 & At2g01570 & gibberellin response modulator (RGA1) & 0 \\
\hline GRAS & aCL3779Contig1 & At2g29060 & scarecrow transcription factor family protein & $1 \mathrm{E}-113$ \\
\hline GRAS & aCL1853Contig1 & At5g52510 & scarecrow-like transcription factor 8 (SCL8) & $1 \mathrm{E}-138$ \\
\hline GRF & aCL5415Contig1 & At5g53660 & growth regulating factor (GRF7) & $4 \mathrm{E}-07$ \\
\hline HD-BEL & aCL4929Contig1 & At2g23760 & similar to BEL1-like homeobox 2 protein (BLH2) & $1 \mathrm{E}-127$ \\
\hline HD-BEL & aCL157Contig1 & At2g35940 & similar to BEL1-like homeobox 4 protein (BLH4) & $9 \mathrm{E}-09$ \\
\hline HD-BEL & aCL1577Contig1 & At2g35940 & similar to BEL1-like homeobox 4 protein (BLH4) & $5 \mathrm{E}-29$ \\
\hline HD-Zip I & aC01011D06SK_c & At1g69780 & homeobox-leucine zipper protein 13 (HB-13) & $1 E-58$ \\
\hline HD-Zip I & aCL6484Contig1 & At5g65310 & homeobox-leucine zipper protein 5 (HB-5) & $1 \mathrm{E}-40$ \\
\hline HD-Zip II & aCL997Contig1 & At4g16780 & homeobox-leucine zipper protein 4 (HAT4) & 4E-84 \\
\hline HD-Zip II & aCL228Contig1 & At4g37790 & homeobox-leucine zipper protein 22 (HAT22) & $3 \mathrm{E}-74$ \\
\hline HD-Zip III & aCL6460Contig1 & At1g52150 & homeobox-leucine zipper family protein & $5 E-88$ \\
\hline HD-Zip IV & aC02015G09SK_c & At3g61150 & homeobox-leucine zipper family protein & 7E-17 \\
\hline HD-HOX7 like & aC02006F10SK_c & At1g28420 & homeobox transcription factor & 9E-32 \\
\hline HD-KNOXI & aC02004E05SK_c & At1g23380 & homeobox transcription factor (KNAT6) & $1 \mathrm{E}-64$ \\
\hline HD-KNOX II & aCL1472Contig1 & At5g25220 & similar to knotted-1 like 4 (KNAT4) & $1 \mathrm{E}-151$ \\
\hline HRT & aCL8507Contig1 & At5g56780 & similar to transcription factor & $2 \mathrm{E}-50$ \\
\hline HSF & aC04011G02SK_c & At4g36990 & heat shock factor protein 4 (HSF4) & $3 \mathrm{E}-27$ \\
\hline HSF & aCL432Contig1 & At4g36990 & heat shock factor protein 4 (HSF4) & $1 E-82$ \\
\hline JUMONJI & aCL7189Contig1 & At4g20400 & transcription factor jumonji (jmj) family protein & $4 \mathrm{E}-26$ \\
\hline LOB Class II & aCL1240Contig1 & At5g67420 & lateral organ boundaries protein 37 (LBD37) & $1 \mathrm{E}-73$ \\
\hline MADS-Type I & aCL8174Contig1 & At5g60440 & MADS-box protein (AGL62) & $2 \mathrm{E}-07$ \\
\hline MADS-Type II & aCL176Contig1 & At1g24260 & MADS-box protein (AGL9) & 9E-93 \\
\hline MADS-Type II & aCL4207Contig1 & At3g58780 & agamous-like shatterproof 1 (SHP1) & 7E-85 \\
\hline MADS-Type II & aCL2625Contig1 & At4g18960 & floral homeotic protein AGAMOUS (AG) & 5E-96 \\
\hline MADS-Type II & aCL3917Contig1 & At4g22950 & MADS-box protein (AGL19) & $5 E-59$ \\
\hline MADS-Type II & aC01009F11SK_c & At5g10140 & MADS-box protein flowering locus F (FLF) & $4 \mathrm{E}-22$ \\
\hline MADS-Type II & aC20007B02SK_c & At5g20240 & floral homeotic protein PISTILLATA (PI) & $1 \mathrm{E}-20$ \\
\hline MADS-Type II & aCL8484Contig1 & At5g20240 & floral homeotic protein PISTILLATA (PI) & $8 \mathrm{E}-65$ \\
\hline MADS-Type II & aCL3805Contig1 & At5g62165 & similar to MADS-box protein (AGL20) & $1 E-54$ \\
\hline MADS-Type II & aCL5010Contig1 & At5g65050 & MADS-box protein (MAF2) & $3 \mathrm{E}-24$ \\
\hline MIF subfamily & aCL9040Contig1 & At3g28917 & zinc finger homeobox family protein & $2 \mathrm{E}-21$ \\
\hline MYB-atypical & aC04018B08SK_c & At4g11400 & ARID/BRIGHT DNA-binding protein & $5 E-15$ \\
\hline MYB-CCA1-like & aCL2656Contig1 & At1g01060 & similar to myb transcription factor (CCA1) & $1 E-103$ \\
\hline MYB-CCA1-like & aCL3899Contig1 & At3g09600 & myb family transcription factor & $1 \mathrm{E}-72$ \\
\hline MYB-CCA1-like & aCL973Contig1 & At5g47390 & myb family transcription factor & $1 \mathrm{E}-114$ \\
\hline MYB-like & aC01005B03SK_c & At4g39250 & myb family transcription factor & $1 \mathrm{E}-06$ \\
\hline MYB-R-R-type & aC20001D01SK_c & At2g38090 & myb family transcription factor & $4 \mathrm{E}-54$ \\
\hline MYB-TBP-like & aCL3396Contig1 & At1g72650 & myb family transcription factor & $4 \mathrm{E}-55$ \\
\hline MYB-TBP-like & aC20010D05SK_c & At5g03780 & expressed protein & $2 E-15$ \\
\hline MYB-TBP-like & aC05004G07SK_c & At5g03780 & expressed protein & $5 E-13$ \\
\hline NAC & aCL943Contig1 & At1g01720 & no apical meristem (NAM) family protein & $1 \mathrm{E}-112$ \\
\hline NAC & aCL267Contig2 & At1g01720 & no apical meristem (NAM) family protein & $1 \mathrm{E}-100$ \\
\hline NAC & aCL7982Contig1 & At1g33060 & no apical meristem (NAM) family protein & $2 \mathrm{E}-06$ \\
\hline NAC & aCL1571Contig1 & At1g69490 & no apical meristem (NAM) family protein & $2 \mathrm{E}-89$ \\
\hline NAC & aCL157Contig2 & At3g04070 & no apical meristem (NAM) family protein & $6 \mathrm{E}-88$ \\
\hline NAC & aCL2766Contig1 & At3g10480 & $\begin{array}{l}\text { no apical meristem (NAM) family protein } \\
\text { no apical meristem (NAM) family protein }\end{array}$ & 3E-91 \\
\hline NAC & aCL728Contig2 & At3g15510 & (NAC2) & 3E-95 \\
\hline NAC & aCL35Contig3 & At4g27410 & no apical meristem (NAM) family protein (RD26) & $1 \mathrm{E}-105$ \\
\hline NAC & aCL8380Contig1 & At4g35580 & no apical meristem (NAM) family protein & $1 \mathrm{E}-72$ \\
\hline NAC & aCL4040Contig1 & At5g04410 & no apical meristem (NAM) family protein & $1 \mathrm{E}-128$ \\
\hline NAC & aCL3976Contig1 & At5g13180 & no apical meristem (NAM) family protein & 4E-81 \\
\hline R1R2R3-MYB & aCL6786Contig1 & At4g32730 & myb family transcription factor & $1 \mathrm{E}-21$ \\
\hline R1R2R3-MYB & aC07001B04SK_c & At4g32730 & myb family transcription factor & $2 \mathrm{E}-33$ \\
\hline R2R3-MYB & aCL5017Contig1 & At1g17950 & myb family transcription factor (MYB52) & $2 \mathrm{E}-71$ \\
\hline R2R3-MYB & aC01006C11SK_c & At1g63910 & myb family transcription factor (MYB103) & 9E-70 \\
\hline R2R3-MYB & aCL413Contig1 & At1g68320 & myb family transcription factor (MYB62) & $6 \mathrm{E}-62$ \\
\hline
\end{tabular}




\begin{tabular}{|c|c|c|c|c|}
\hline R2R3-MYB & aC02008E10SK_c & At2g37630 & myb family transcription factor (MYB91) & $5 E-18$ \\
\hline R2R3-MYB & aC20006B02SK_c & At2g37630 & myb family transcription factor (MYB91) & $8 \mathrm{E}-46$ \\
\hline R2R3-MYB & aC03004B08SK_c & At3g23250 & myb family transcription factor (MYB15) & $5 E-40$ \\
\hline R2R3-MYB & aCL6070Contig1 & At3g27810 & myb family transcription factor (MYB3) (MYB21) & 7E-64 \\
\hline R2R3-MYB & aCL2843Contig1 & At3g30210 & myb family transcription factor (MYB121) & $1 E-51$ \\
\hline R2R3-MYB & aC18004B12Rv_c & At4g21440 & myb family transcription factor (MYB102) & $3 E-12$ \\
\hline R2R3-MYB & aCL8980Contig1 & At4g21440 & myb family transcription factor (MYB102) & $2 \mathrm{E}-18$ \\
\hline R2R3-MYB & aCL1337Contig3 & At4g38620 & myb family transcription factor (MYB4) & $2 \mathrm{E}-73$ \\
\hline R2R3-MYB & aCL7866Contig1 & At5g49620 & myb family transcription factor (MYB78) & $3 E-48$ \\
\hline R2R3-MYB & aCL693Contig1 & At5g67300 & myb family transcription factor & $7 \mathrm{E}-63$ \\
\hline SBP & aCL6731Contig1 & At2g47070 & squamosa promoter-binding protein (SPL1) & $1 \mathrm{E}-24$ \\
\hline TCP & aCL5534Contig1 & At2g30410 & tubulin folding cofactor A (KIESEL) & $2 E-34$ \\
\hline TUB & aCL1192Contig1 & At1g25280 & F-box family protein / tubby family protein & $1 E-168$ \\
\hline TUB & aCL9120Contig1 & At2g18280 & tubby-like protein & $7 \mathrm{E}-59$ \\
\hline TUB & aCL7933Contig1 & At2g47900 & tubby-like protein & $1 \mathrm{E}-175$ \\
\hline VOZ-9 & aC20003C09SK_c & At1g28520 & expressed protein & $5 \mathrm{E}-67$ \\
\hline WHIRLY & aCL8737Contig1 & At1g71260 & expressed protein & $1 \mathrm{E}-48$ \\
\hline WRKY & aCL5056Contig1 & At2g04880 & WRKY family transcription factor (ZAP1) & $8 \mathrm{E}-32$ \\
\hline WRKY & aCL1506Contig1 & At2g38470 & WRKY family transcription factor & $1 \mathrm{E}-104$ \\
\hline WRKY & aC04005E02SK_c & At4g01720 & WRKY family transcription factor & $4 \mathrm{E}-11$ \\
\hline WRKY & aCL3680Contig1 & At4g18170 & WRKY family transcription factor & 7E-51 \\
\hline WRKY & aCL1201Contig1 & At4g22070 & WRKY family transcription factor & $1 \mathrm{E}-111$ \\
\hline WRKY & aCL3000Contig1 & At4g23810 & WRKY family transcription factor & $4 \mathrm{E}-57$ \\
\hline WRKY & aCL1204Contig3 & At4g26640 & WRKY family transcription factor & $3 E-37$ \\
\hline WRKY & aC07003C03SK_c & At4g39410 & WRKY family transcription factor & $4 \mathrm{E}-21$ \\
\hline ZF-HD & aCL4549Contig1 & At1g69600 & zinc finger homeobox family protein & $1 \mathrm{E}-57$ \\
\hline ZF-HD & aCL1228Contig1 & At4g24660 & zinc finger homeobox family protein & $1 E-58$ \\
\hline
\end{tabular}



